Universidade de São Paulo

Escola Superior de Agricultura "Luiz de Queiroz"

O Plano e Programa ABC: uma avaliação da execução e distribuição dos recursos

\title{
Giovani William Gianetti
}

Dissertação apresentada para obtenção do título de Mestre em Ciências. Área de concentração: Economia Aplicada

Piracicaba 
Giovani William Gianetti

Bacharel em Ciências Econômicas

O Plano e Programa ABC: uma avaliação da execução e distribuição dos recursos

Orientador:

Prof. Dr. JOAQUIM BENTO DE SOUZA FERREIRA FILHO

Dissertação apresentada para obtenção do título de Mestre em Ciências. Área de concentração: Economia Aplicada 


\section{Dados Internacionais de Catalogação na Publicação DIVISÃO DE BIBLIOTECA - DIBD/ESALQ/USP}

\section{Gianetti, Giovani William}

O Plano e Programa ABC: uma avaliação da execução e distribuição dos recursos / Giovani William Gianetti. - - Piracicaba, 2017.

$123 \mathrm{p}$.

Dissertação (Mestrado) - - USP / Escola Superior de Agricultura "Luiz de Queiroz".

1. Agricultura de baixa emissão de carbono 2. Crédito rural 3. Políticas públicas I. Título 
Dedico este trabalho a Deus e minha família. 


\section{AGRADECIMENTOS}

Agradeço a minha família, em especial minha mãe, Claudia, e meu irmão, Eric, pelo apoio incondicional. Agradeço ao meu pai, Renato, que recentemente nos deixou, mas vive em nossos corações e memórias.

A minha namorada, Alessandra, pelo amor, carinho e pelas palavras de conforto nos momentos mais dificéis.

Aos meus tios, Wilson e Clelia, pela hospitalidade.

Agradeço à todos os meus amigos de Campo Grande, que apesar da distância, sempre estiveram presentes.

Agradeço a Escola Superior de Agricultura "Luiz de Queiroz”, aos colegas, funcionários, professores e demais membros do Programa de Pós-Graduação em Economia Aplicada.

Em especial, gostaria de agradecer ao meu orientador, Dr. Joaquim Bento de Souza Ferreira Filho, pela oportunidade, paciência e conselhos que fizeram possível a realização deste trabalho.

Sou grato as contribuições dos membros da banca de qualificação, Dr. Alexandre Nunes de Almeida, Dr. Carlos Eduardo de Freitas Vian e Dr. Gerd Sparovek.

Agradeço à CAPES pelo apoio financeiro para realização deste trabalho. 
SUMÁRIO

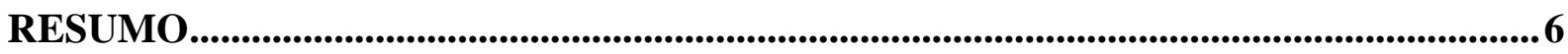

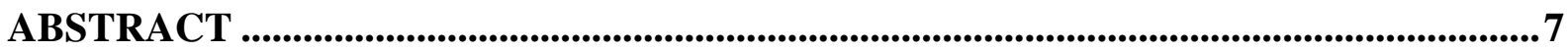

LISTA DE FIGURAS........................................................................................................

LISTA DE TABELAS …………....................................................................................9

1. INTRODUÇÃO ................................................................................................................................11

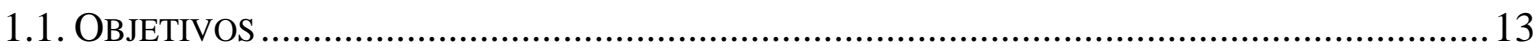

2. REVISÃO BIBLIOGRÁFICA ...............................................................................15

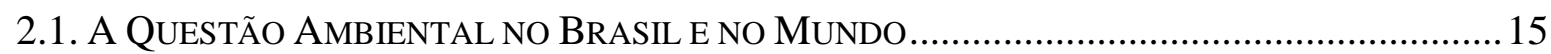

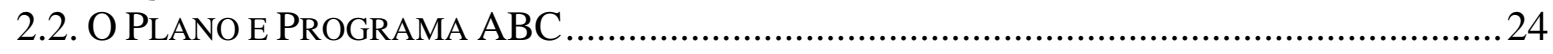

3. METODOLOGIA......................................................................................................................39

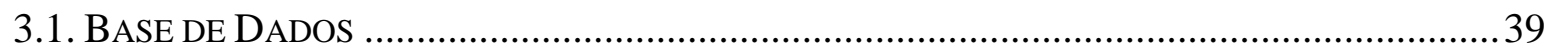

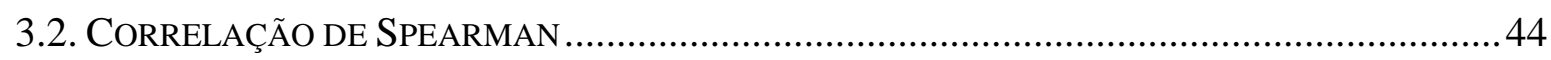

4. RESULTADOS E DISCUSSÃO ….........................................................................47

4.1. ExecuÇão e Distribuição de Recursos do Plano e Programa ABC: Aptidẽo

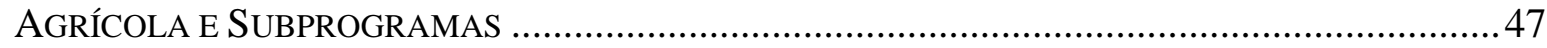

4.2. Execução e Distribuição de Recursos do Plano e Programa ABC: Aptidẽo AgríCOLA E ATIVIDAdES (AgRÍCOLA E PECUÁRIA) .............................................................. 61

4.3. CORRELAÇÃo DE SPEARMAN E DisCuSSÃo PARA AMPLIAÇÃo DA EFICÁCIA E EFICIÊNCIA

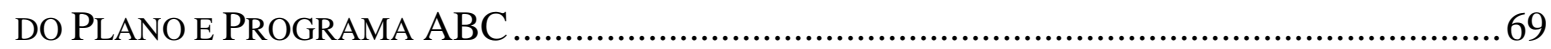

4.4. ESPECIFICIDADES AdICIONAIS DO PERFIL AGROPECUÁRIO E DAS MODALIDADES ...........76

5. CONSIDERAÇÕES FINAIS......................................................................................................81

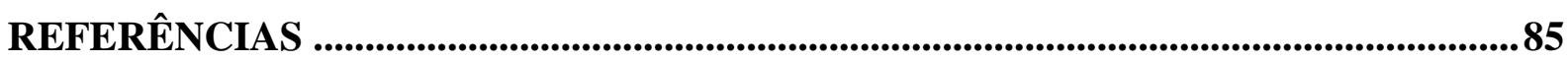

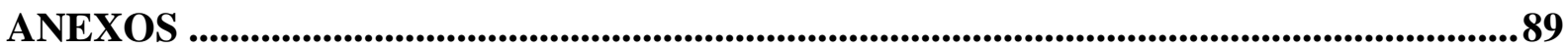


RESUMO

O Plano e Programa ABC: uma avaliação da execução e distribuição dos recursos

A importância das mudanças climáticas no cenário econômico-político internacional é crescente e os esforços para a geração e utilização de tecnologias de baixa emissão de carbono vêm se ampliando. Neste sentido que o Plano ABC é implementado nas propriedades rurais através de linha de Crédito Rural denominada Programa ABC. Os estados e municípios brasileiros possuem grandes disparidades econômicas e edafoclimáticas, apresentando adoção heterogênea de tecnologia no meio rural. Deste modo, o presente trabalho visa analisar a execução e distribuição dos recursos do Plano e Programa ABC, avaliando a aplicação destes de modo a atender os objetivos do projeto. Serão utilizadas informações dos empréstimos do Programa ABC de 2013 a 2016 obtidos através do SICOR, variáveis de desempenho da agropecuária obtidas com o IBGE e classificação de aptidão agrícola predominante nos municípios realizada por Sparovek (2015) para a obtenção de estatísticas e correlação de Spearman. Os resultados demonstram que as linhas de financiamento do $\mathrm{ABC}$ Recuperação, $\mathrm{ABC}$ Plantio Direto, $\mathrm{ABC}$ Florestas e $\mathrm{ABC}$ Integração correspondem à parcela superior a $98 \%$ do volume de crédito concedido. A maioria dos recursos é absorvida pelo Centro-Oeste e Sudeste. As regiões Norte e Nordeste possuem maior carência em produtividade agropecuária, portanto, os empréstimos do $\mathrm{ABC}$ nestas regiões resultariam em maiores impactos de mitigação de GEE, mas o volume de recursos destinado para as mesmas é baixo. Os resultados mostram que os recursos são destinados em sua maioria a municípios que possuem maior aptidão agrícola e assim devem propiciar menores efeitos de mitigação de GEE. Calculou-se que os empréstimos são mais fortemente relacionados com o rebanho bovino do que com as pastagens degradadas. Além disto, os investimentos realizados nas regiões de aptidão agrícola mais elevada possuem maior correlação com características econômicas. Para ampliar a eficiência da execução e distribuição dos recursos do Plano e Programa $\mathrm{ABC}$, alterações que contemplem a possibilidade de aderência a múltiplos sistemas produtivos e a diferenciação de incentivos conforme definições de áreas prioritárias poderiam ser realizadas.

Palavras-chave: Agricultura de baixa emissão de carbono; Crédito rural; Políticas públicas 


\begin{abstract}
The ABC Plan and Program: an evaluation of the execution and distribution of resources
\end{abstract}

The importance of climate change in the international economic and political scenario is growing, and efforts for the generation and use of low-carbon technologies have been expanding. In this sense, the ABC Plan is implemented in rural properties through the rural crédit line called the ABC Program. The brazilian states and municipalities have great economic and edaphoclimatic disparities, presenting heterogeneous adoption of technology in rural areas. Thus, the present work aims to analyze the execution and distribution of resources of the ABC Plan and Program, evaluating their application in order to meet the project objectives. Information from the ABC Program loans from 2013 to 2016 obtained through SICOR, agricutural performance variables obtained with the IBGE and the calssification of predominant agricultural aptitude in the municipalities by Sparovek (2015) will be used to obtain statistics and Spearman correlation. Results show that the loans of ABC Recovery, ABC Direct Planting, ABC Forests and $\mathrm{ABC}$ Integration correspond up to $98 \%$ of the volume of credit granted. Most of the resources are absorbed by the Midwest and Southeast regions. The North and Northeast regions have greater deficiencies in agricultural productivity, therefore, the $\mathrm{ABC}$ loans in these regions would result in greater impacts of GHG mitigation, but the volume of resources allocated to them is low. Results show also that resources are mostly destined to municipalities that have greater agricultural aptitude and thus should provide less mitigation effects of GHG. Loans were estimated to be more strongly correlated to the cattle herd than to degraded pastures. In addition, investments made in regions with the highest agricultural aptitude have a higher correlation with economic characteristics. In order to increase the efficiency of the execution and distribution of the resources of the ABC Plan and Program, changes that contemplate the possibility of adherence to multiple productive systems and the differentiation of incentives according to definitions of priority areas could be realized.

Keywords: Low carbon agriculture; Rural credit; Public policies 
FIGURA 1. EMISSÕES DE GEE DO BRASIL POR SETORES DE ATIVIDADE DE 1990-2012.............17

FIGURA 2. CLASSES DE APT PARA O TERRITÓRIO BRASILEIRO................................................43

FIGURA 3. LEGENDA DE CORES DOS MAPAS DE QUANTIL .........................................................52

FIGURA 4. DISTRIBUIÇÃO DO CRÉDITO EM RPD NOS MUNICÍPIOS BRASILEIROS. MAPAS SUPERIORES DA APT “A” E "B”, INFERIORES DA “CD” E DO TOTAL. ...............................................56

FIGURA 5. DISTRIBUIÇÃO DO CRÉDITO EM SPD NOS MUNICÍPIOS BRASILEIROS. MAPAS SUPERIORES DA APT “A” E "B", INFERIORES DA “CD" E DO TOTAL. ...............................................58

FIGURA 6. DISTRIBUIÇÃO DO CRÉDITO EM FLP NOS MUNICÍPIOS BRASILEIROS. MAPAS SUPERIORES DA APT “A” E "B”, INFERIORES DA “CD” E DO TOTAL. .............................................59

FIGURA 7. DISTRIBUIÇÃO DO CRÉDITO EM ILPF NOS MUNICÍPIOS BRASILEIROS. MAPAS SUPERIORES DA APT “A” E "B”, INFERIORES DA “CD” E DO TOTAL .............................................60

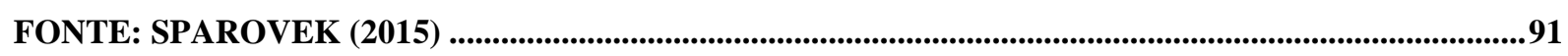

FIGURA 8. ESQUEMA SIMPLIFICADO DE GERAÇÃO DO ÍNDICE MÉDIO DE QUALIDADE DE

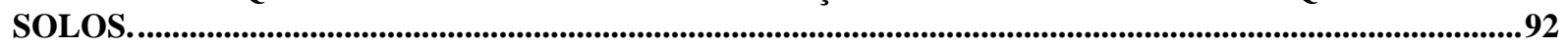

FIGURA 9. ESQUEMA SIMPLIFICADO DE GERAÇÃO DAS CLASSES DE APTIDÃO CLIMÁTICA

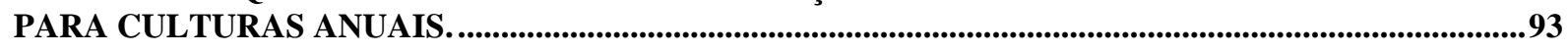

FIGURA 10. ESQUEMA SIMPLIFICADO DE CÁlCULO DAS CLASSES DE DECLIVIDADE DO

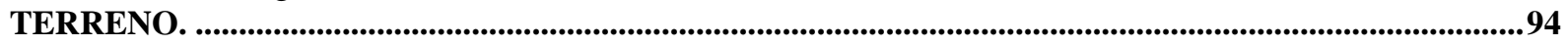

FIGURA 11. ESQUEMA SIMPLIFICADO DE INTEGRACृ̃̃O DAS DIMENSÕES SOLOS, CLIMA E TOPOGRAFIA NA GERAÇÃ̃ DAS CLASSES DE APTIDÃ̃o AGRÍCOLA.............................................95

FIGURA 12. BASES DE DADOS CLIMÁTICOS UTILIZADAS...................................................................97

FIGURA 13. REFERÊNCIA DAS EQUAÇÕES DE REGRESSÃO UTILIZADAS EM CADA UMA DAS REGIÕES DO BRASIL PARA ESTIMATIVA DA TEMPERATURA MÉDIA MENSAL ..........................98 
LISTA DE TABELAS

TABELA 1. DESCRIÇÃO DAS BASES DE DADOS UTILIZADAS, CRÉDITO EM REAIS E ÁREA EM HECTARES.

TABELA 2. CLASSIFICAÇÃO DO PERFIL AGROPECUÁRIO.

TABELA 3. LEGENDA DE SIGLAS PARA OS RESULTADOS.............................................................44

TABELA 4. CRÉDITO CONCEDIDO (EM MILHÕES DE REAIS), ÁREA (EM HECTARES) E CONTRATOS POR SUBPROGRAMAS E REGIÕES.

TABELA 5. VALOR MÉDIO DOS CONTRATOS E POR HECTARE POR SUBPROGRAMAS E REGIÕES. EM REAIS.

TABELA 6. CRÉDITO CONCEDIDO, ÁREA $E$ QUANTIDADE DE CONTRATOS POR SUBPROGRAMAS, REGIÕES E APT, EM RELAÇÃ̃O AO TOTAL DAS REGIÕES. EM PORCENTAGEM $(\%)$.

TABELA 7. CRÉDITO CONCEDIDO, ÁREA E QUANTIDADE DE CONTRATOS POR SUBPROGRAMAS, REGIÕES E APT EM RELAÇÃO AO TOTAL DO BRASIL. EM PORCENTAGEM (\%).

TABELA 8. VALORES MÉDIOS POR CONTRATOS (EM MIL REAIS) E HECTARES (EM REAIS) DOS SUBPROGRAMAS, REGIÕES E APT.

TABELA 9. PARTICIPAÇÃO NO CRÉdITO CONCEDIDO POR SUBPROGRAMA, APT E ATIVIDADE, EM RELAÇÃO AO TOTAL DO SUBPROGRAMA EM CADA ATIVIDADE. EM PORCENTAGEM (\%) .

TABELA 10. CRÉDITO CONCEDIDO E OBSERVAÇÕES EM ATIVIDADE AGRÍCOLA POR SUBPROGRAMAS, REGIÕES E APT, EM RELAÇÃO AO TOTAL DO BRASIL. EM PORCENTAGEM $(\%)$

TABELA 11. CRÉDITO CONCEDIDO E OBSERVAÇÕES EM ATIVIDADE PECUÁRIA POR SUBPROGRAMAS, REGIÕES E APT, EM RELAÇÃO AO TOTAL DO BRASIL. EM PORCENTAGEM $(\%)$.

TABELA 12. CORRELAÇÃO DE SPEARMAN POR APT E TOTAL DOS EMPRÉSTIMOS DO PROGRAMA ABC COM VARIÁVEIS SELECIONADAS

TABELA 13. CORRELAÇÃO DE SPEARMAN DO CRÉDITO CONCEDIDO AOS PRINCIPAIS SUBPROGRAMAS DO ABC COM VARIÁVEIS SELECIONADAS

TABELA 14. PARTICIPAÇÃO NO CRÉDITO CONCEDIDO TOTAL POR SUBPROGRAMAS, PERFIL AGROPECUÁRIO E APT, EM RELAÇÃO AO TOTAL DE CRÉDITO CONCEDIDO NO BRASIL. EM PORCENTAGEM (\%)

TABELA 15. FONTE DOS DADOS DE ALIMENTAÇÃO DO MODELO DE APTIDÃO. 91

TABELA 16. CRÉDITO CONCEDIDO POR SUBPROGRAMA, REGIÃO E APT, EM RELAÇÃO AO TOTAL DA REGIÃO. EM PORCENTAGEM (\%)

TABELA 17. ÁREA POR SUBPROGRAMA, REgIÃo E APT, EM RELAÇÃO AO TOTAL DA REGIÃO. EM PORCENTAGEM (\%)

TABELA 18. CONTRATOS POR SUBPROGRAMA, REGIÃO E APT, EM RELAÇÃO AO TOTAL DA REGIÃO. EM PORCENTAGEM (\%).

TABELA 19. CRÉDITO CONCEDIDO POR SUBPROGRAMA, REGIÃO E APT EM RELAÇÃO AO TOTAL DO BRASIL. EM PORCENTAGEM (\%)

TABEla 20. ÁREA POR SUbPROGRAMA, REgĩ̃o E APT EM RELAÇÃo AO TOTAL do BRASIL. EM PORCENTAGEM (\%)

TABELA 21. CONTRATOS POR SUBPROGRAMA, REGIÃO E APT EM RELAÇÃO AO TOTAL DO BRASIL. EM PORCENTAGEM (\%) 
TABELA 22. VALORES MÉDIOS DOS CONTRATOS POR SUBPROGRAMAS, REGIÕES E APT. EM MIL REAIS. 106

TABELA 23. VALORES MÉDIOS POR HECTARE DOS CONTRATOS POR SUBPROGRAMAS, REGIÕES E APT. EM REAIS. 107

TABELA 24. CRÉDITO CONCEDIDO, ÁREA E QUANTIDADE DE CONTRATOS POR SUBPROGRAMAS, PERFIS AGROPECUÁRIOS E APT “A”, EM RELAÇÃO À PARTICIPAÇÃO TOTAL DOS PERFIS EM CADA SUBPROGRAMA. EM PORCENTAGEM (\%). 108

TABELA 25. CRÉDITO CONCEDIDO, ÁREA E QUANTIDADE DE CONTRATOS POR SUBPROGRAMAS, PERFIS AGROPECUÁRIOS E APT "B" EM RELAÇÃO À PARTICIPAÇÃO TOTAL DOS PERFIS EM CADA SUBPROGRAMA. EM PORCENTAGEM (\%). 109

TABELA 26. CRÉDITO CONCEDIDO, ÁREA E QUANTIDADE DE CONTRATOS POR SUBPROGRAMAS, PERFIS AGROPECUÁRIOS E APT “CD” EM RELAÇÃO À PARTICIPAÇÃO TOTAL DOS PERFIS EM CADA SUBPROGRAMA. EM PORCENTAGEM (\%). 110

TABELA 27. CRÉDITO CONCEDIDO AGRÍCOLA POR SUBPROGRAMA, REGIÃO E APT, EM RELAÇÃO AO TOTAL DA REGIÃO. EM PORCENTAGEM (\%) ........................................................112

TABELA 28. CRÉDITO CONCEDIDO À PECUÁRIA POR SUBPROGRAMA, REGIÃO E APT, EM RELAÇÃO AO TOTAL DA REGIÃO. EM PORCENTAGEM (\%) ............................................................113

TABELA 29. OBSERVAÇÕES AGRÍCOLAS POR SUBPROGRAMA, REGIÃO E APT, EM RELAÇÃO AO TOTAL DA REGIÃO. EM PORCENTAGEM (\%) .....................................................114

TABELA 30. OBSERVAÇÕes À PECUÁRIA POR SUBPROGRAMA, REgIÃo E APT, EM RELAÇÃO AO TOTAL DA REGIÃO. EM PORCENTAGEM (\%) ...............................................................115

TABELA 31. CRÉDITO CONCEDIDO AGRÍCOLA POR SUBPROGRAMAS, REGIÕES E APT, EM RELAÇÃO AO TOTAL DO BRASIL. EM PORCENTAGEM (\%)..........................................................116

TABELA 32. OBSERVAÇÕES AGRíCOLAS POR SUBPROGRAMAS, REgIÕES E APT, EM RELAÇÃO AO TOTAL DO BRASIL. EM PORCENTAGEM (\%)............................................................117

TABELA 33. CRÉDITO CONCEDIDO À PECUÁRIA POR SUBPROGRAMAS, REGIÕES E APT, EM RELAÇÃO AO TOTAL DO BRASIL. EM PORCENTAGEM (\%)..........................................................118

TABELA 34. OBSERVAÇÕES DA PECUÁRIA POR SUBPROGRAMAS, REGIÕES E APT, EM RELAÇÃ O AO TOTAL DO BRASIL. EM PORCENTAGEM (\%)......................................................119 TABELA 35. CRÉdito CONCEDIDO E OBSERVAÇÕES EM RPD, POR REgIÕES E MODALIDADES, EM RELAÇÃO AO TOTAL DAS REGIÕES E DO BRASIL. EM PORCENTAGEM $(\%)$. .120

TABELA 36. CRÉDITO CONCEDIDO E OBSERVAÇÕES EM SPD, POR REGIÕES E MODALIDADES, EM RELAÇÃO AO TOTAL DAS REGIÕES E DO BRASIL. EM PORCENTAGEM $(\%)$. 121

TABELA 37. CRÉdito CONCEDIDO E OBSERVAÇÕES EM ILPF, POR REGIÕES E MODALIDADES, EM RELAÇÃO AO TOTAL DAS REGIÕES E DO BRASIL. EM PORCENTAGEM $(\%)$. .122

TABELA 38. CRÉDITO CONCEDIDO E OBSERVAÇÕES EM FLP, POR REGIÕES E MODALIDADES, EM RELAÇÃO AO TOTAL DAS REGIÕES E DO BRASIL. EM PORCENTAGEM (\%). .123 


\section{INTRODUÇÃO}

No período de 1990 até 2012 o Brasil contribuiu em média com 4,68\% das emissões de Gases do Efeito Estufa (GEE) do mundo. A mudança do uso da terra e a agropecuária são as atividades brasileiras que mais emitem GEE. A mudança de uso da terra é expressa majoritariamente através do "desmatamento", atividade diretamente associada à expansão do agronegócio, principalmente da pecuária (OBSERVATÓRIO DO CLIMA, 2014).

A consciência da importância da preservação do meio ambiente e dos recursos naturais ampliou-se a partir da primeira iniciativa da Organização das Nações Unidas (ONU) sobre o tema, a Conferência das Nações Unidas sobre o Meio Ambiente Humano de 1972. As Conferências da ONU abordaram questões importantes para o desenvolvimento da consciência com a degradação do meio ambiente, como a destruição da camada de ozônio e o efeito estufa. Estas iniciativas originaram documentos e diretrizes para um desenvolvimento sustentável como a Agenda 21, o Protocolo de Quioto, a pretendida Contribuição Nacionalmente Determinada (intended Nationally Determined Contribution - iNDC) e outros acordos globais para a redução da emissão de GEE (BRASIL, 2012).

A identificação do problema de elevadas emissões no setor agropecuário, bem como a ampliação da consciência internacional sobre a preservação do meio ambiente, incentivou a adoção voluntária de compromisso na $15^{\mathrm{a}}$ Conferência das Partes (COP-15) em 2009 para a redução da emissão de GEE entre 36,1\% e 38,9\% até 2020, com orçamento estimado em cerca de R 197 bilhões. A Política Nacional de Mudança do Clima (PNMC) criada em 2009 originou o Plano Setorial de Mitigação e de Adaptação ás Mudanças Climáticas para a Consolidação de uma Economia de Baixa Emissão de Carbono na Agricultura (Plano ABC) para atuação no período de 2010 até 2020. Os objetivos do Plano ABC estão direcionados para o desenvolvimento de ações para mitigação de emissões de GEE, bem como melhoria da qualidade de solos, recuperação de áreas degradadas, redução do desmatamento, fixação de biomassa e tratamento de dejetos, realizados através do incentivo a adoção de sistemas produtivos agropecuários mais sustentáveis e eficientes. Para a execução do Plano ABC elaborou-se o então Programa para a Redução da Emissão de Gases de Efeito Estufa na Agricultura (Programa ABC), um programa de crédito associado ao Crédito Rural, com taxas de juros subsidiadas (MINISTÉRIO DA AGRICULTURA PECUÁRIA E ABASTECIMENTO, 2012).

O compromisso firmado na COP-15 foi reforçado na COP-21 através da ratificação da iNDC. Neste compromisso, os países signatários da Convenção do Clima acordaram em 
introduzir ações para limitar o crescimento da temperatura média global em $2^{\circ} \mathrm{C}$ em relação aos níveis pré-industriais. O Brasil comprometeu-se a reduzir suas emissões de GEE em nível $37 \%$ e $43 \%$ menor que os apresentados em 2005, a primeira meta deve ser cumprida até 2025 e a segunda até 2030. Para alcançar o objetivo o país propôs realizar diversas ações, entre elas, a intenção de ampliar e fortalecer o Plano ABC, com meta de recuperação adicional de 15 milhões de hectares com pastagens degradadas e implementando mais 5 milhões de hectares em sistema de integração Lavoura-Pecuária-Floresta (iLPF) (BRASIL, 2015)

Os objetivos expostos no Plano e Programa ABC e fortalecidos pela iNDC de redução de emissões de GEE na ordem de $40 \%$ representam um grande desafio, principalmente devido ao histórico de baixo comprometimento com acordos ambientais, como o ocorrido com o Protocolo de Quioto. Os desafios do Plano e Programa ABC são exacerbados pelas dificuldades que podem surgir ao introduzir as inovações tecnológicas e de manejo no meio rural, além da necessidade de fazer cumprir a proposta do Plano em garantir conjuntamente melhorias ambientais, climáticas, de produtividade, eficiência e lucratividade nas propriedades rurais. Conhecendo a grande extensão territorial do Brasil, as enormes disparidades do clima, do solo, dos cultivos regionais, dos arranjos produtivos, do nível tecnológico, educacional, de capital e tamanho dos produtores rurais, além de profundas desigualdades regionais de renda e indicadores sociais, este trabalho busca verificar se os recursos concedidos para a implementação das inovações tecnológicas e técnicas de manejo do Plano ABC, expostas nas linhas de crédito do Programa $\mathrm{ABC}$, estão sendo aplicados de acordo com as necessidades ambientais e características regionais de modo a atender os objetivos do projeto.

Existem evidências da insuficiência da execução dos recursos do Programa $A B C$, principalmente quando comparadas às necessidades para cumprir metas previstas pelo Plano ABC. Também existem indícios sobre a heterogeneidade na alocação dos recursos entre regiões, estados e municípios. A verificação destes fatores e, sobretudo, a coerência dos empréstimos com características ambientais das regiões beneficiadas são características exploradas neste trabalho.

Além desta seção o presente trabalho é composto de outras quatro seções. A segunda seção apresenta a revisão de literatura, abordando a questão ambiental e aspectos sobre o Plano e Programa ABC. A terceira seção é dedicada a detalhar os procedimentos metodológicos. A quarta seção apresenta os resultados e discussão, enquanto a última seção é dedicada às considerações finais. 


\subsection{Objetivos}

\subsubsection{Objetivo Geral}

O objetivo geral desta pesquisa consiste na caracterização da distribuição de crédito do Programa $\mathrm{ABC}$ no território nacional, para a análise da adequação da alocação dos recursos conforme os objetivos originais do Plano ABC.

\subsubsection{Objetivos Específicos}

Os objetivos específicos deste estudo são:

- Analisar a distribuição dos contratos do Programa $\mathrm{ABC}$ de acordo com os subprogramas, modalidades, atividades, crédito concedido, área, aptidão agrícola e perfil agropecuário;

- Analisar a correlação dos subprogramas do Programa ABC e aptidão agrícola com indicadores como produção animal, produção vegetal e áreas degradadas;

- E a realização de análise qualitativa de maneira a contextualizar e explicar a distribuição encontrada dos recursos aplicados pelo Programa $\mathrm{ABC}$ e as variáveis selecionadas. 


\section{REVISÃO BIBLIOGRÁFICA}

\subsection{A Questão Ambiental no Brasil e no Mundo}

A preservação do meio ambiente e dos recursos naturais é um tema relativamente recente nas ciências econômicas. Para contextualizar a evolução da inserção do meio ambiente no âmbito das políticas públicas e preocupações globais com o desenvolvimento sustentável, serão apresentadas informações referentes ao aquecimento global e problemas ambientais, a participação da agropecuária brasileira nas emissões de GEE, a evolução dos acordos globais a cerca do meio ambiente e exemplos de programas e políticas públicas voltadas à preservação ambiental e dos recursos naturais.

\subsubsection{Aquecimento Global e a Questão Ambiental e Climática}

As pesquisas sobre questões climáticas apontam que a terra durante seus bilhões de anos de existência passou por vários períodos de temperaturas extremas, tanto frias como quentes. O clima por si só é uma variável que expressa muita incerteza, até hoje não se conseguiu precisar como alguns fenômenos se comportam, como exemplos o El Niño ou El Niña ${ }^{1}$. Mesmo com a dificuldade da previsão dos fenômenos naturais, existem estudos que revelam os impactos da disseminação de gases do "efeito estufa" (como o gás carbônico $\left(\mathrm{CO}_{2}\right)$, metano $\left(\mathrm{CH}_{4}\right)$, entre outros) no aquecimento da terra, ao impedirem a saída do calor dos raios solares para o espaço, atuando como uma estufa. Através de várias décadas de discussão da importância da preservação ambiental, consolidou-se internacionalmente a necessidade de refrear a emissão de GEE, comumente associados a atividades como desmatamento, agropecuária, impermeabilização do solo, queima de combustíveis fósseis, etc. (MARENGO, 2006).

De acordo com dados do Quinto Relatório de Avaliação (TAR), produzido pelo Painel Intergovernamental de Mudanças Climáticas (Intergovernmental Panel on Climate Change IPCC, 2014), as temperaturas da terra em 2081-2100 comparadas a 1986-2005 podem sofrer incremento entre $2,6^{\circ} \mathrm{C}$ até $4,8^{\circ} \mathrm{C}$ no cenário mais pessimista e $0,3^{\circ} \mathrm{C}$ a $1,5^{\circ} \mathrm{C}$ no cenário mais otimista. De acordo com o Relatório, serão mais comuns áreas de extremo calor do que frio e haverá uma alteração do regime de chuvas que não será uniforme, mas amplificando áreas de

1 Aquecimento ou resfriamento das águas superficiais do oceano Pacífico Tropical Central e do Leste. 
seca e de extrema chuva. O oceano deve continuar se aquecendo e seu índice de acidez se tornando mais elevado (INTERGOVERNMENTAL PANEL ON CLIMATE CHANGE, 2014).

Alterações climáticas trazem consequências econômicas, a saúde humana e sustentabilidade da vida na Terra. O derretimento de geleiras, maior incidência de secas ou enchentes, erosões da costa marítima e outros efeitos da maré, aumento de incêndios e diminuições da biodiversidade devem afetar a produção de alimentos, bem como tornar mais suscetíveis a ocorrência de doenças (INTERGOVERNMENTAL PANEL ON CLIMATE CHANGE, 2014).

De acordo com Oliveira (2015), as abelhas são fundamentais para a polinização de diversas culturas agrícolas no mundo todo, no entanto, elas vêm sofrendo um processo de extinção em alguns países, principalmente na Europa e na América do Norte. Os fenômenos de alteração climática e do meio-ambiente são apontados como fatores determinantes para a redução da população de abelhas.

Existem métodos matemáticos para avaliar as variáveis de aumento de temperatura, modificações na precipitação e outros fenômenos climáticos de modo a calcular reduções na produtividade agrícola. Os trabalhos de Assad et al. (2004), Pellegrino, Assad e Marin (2007) e Carvalho et al. (2015) apontam elevados prejuízos a produtividade agrícola brasileira se cenários de ampliação de $3^{\circ} \mathrm{C}$ a $5^{\circ} \mathrm{C}$ na temperatura anual média da Terra forem observados.

\subsubsection{A Agropecuária e as Emissões de GEE do Brasil}

Apesar dos elevados investimentos em pesquisa, da produtividade e da tecnologia implementada na produção agropecuária nacional, ainda existem "oportunidades" para incrementar a excelência deste setor.

De acordo com a Food and Agriculture Organization of United Nations (2015), em 2012 o Brasil registrou a $5^{\text {a }}$ colocação mundial no consumo de energia e a $3^{\text {a }}$ maior poluição em termos de $\mathrm{CO}^{2}$ equivalente no setor agropecuário. Adicionalmente, as emissões provenientes da mudança de uso da terra ocupam o $2^{\circ}$ lugar, ainda que o valor absoluto desta emissão tenha se reduzido.

Na Figura 1 observa-se que desde 1990 até 2012 a mudança de uso da terra é o principal fator de emissões de GEE. Este fator está amplamente associado à expansão da fronteira agrícola e consequentemente a abertura de terras (desmatamento) com floresta nativa 
para a conversão em pastos ou lavouras, o que ocorre principalmente na região Amazônica (RIVERO et al., 2009).

Assim, a atividade que ocasiona maiores volumes de emissões de GEE no Brasil está associada ao agronegócio, e a segunda maior fonte de emissões é a própria atividade agropecuária. Da década de 1990 até 2012 a legislação mais severa, mecanismos de controles do desmatamento ilegal e redução das áreas propícias à expansão da fronteira agrícola diminuíram as emissões relativas à mudança de uso da terra, estas que chegaram a alcançar quase $80 \%$ das emissões totais do Brasil em 1995, representam cerca de 30\% em 2012. Ainda que ocorra a redução das emissões de GEE resultante da mudança do uso da terra, as da agropecuária ampliaram sua importância relativa de 20\% em 1990 para 30\% em 2012.

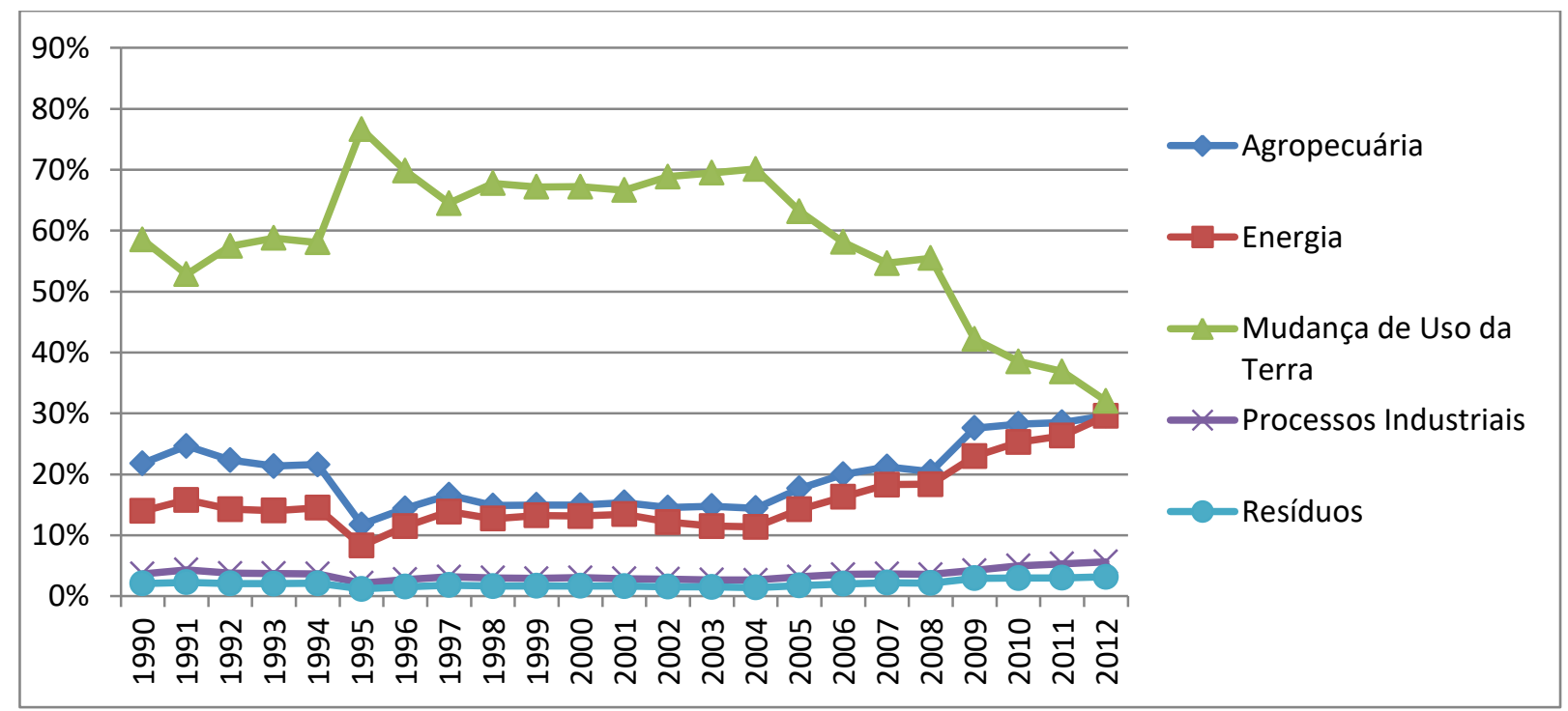

Figura 1. Emissões de GEE do Brasil por setores de atividade de 1990-2012.

Fonte: Dados do Observatório do Clima (2014). Elaboração própria.

Das emissões de GEE ocasionadas no meio rural, a pecuária possui maiores participações. Segundo os dados do Observatório do Clima (2014) esta atividade foi responsável por 50\% das emissões de GEE do país em 2012, isto considerando as emissões da mudança do uso da terra motivadas pela implantação de pecuária, quanto pela emissão de metano $\left(\mathrm{CH}_{4}\right)$ derivado do processo digestivo animal e demais fatores.

A emissão de GEE pela agropecuária brasileira é exacerbada pelas técnicas de manejo, as quais não aproveitam todas as potencialidades do uso da terra. A intensificação dos sistemas produtivos da agropecuária, pressionados pela maior demanda de alimentos e impulsionados pelo incremento tecnológico fez com que os sistemas produtivos se reduzissem 
a atividades de monocultura, associadas à mecanização, ao uso de agroquímicos e uma produção dissociada da pecuária, agricultura e atividades florestais (BALBINO et al., 2011)

Com o tratamento inadequado dos solos e má gestão do rebanho animal, tornou-se frequente a observação de pastagens de baixa produtividade em todo o território nacional. As pastagens de baixa produtividade são caracterizadas pela perda do valor nutricional, principalmente de proteínas. Estas pastagens interferem na produtividade da carne e leite por hectare, bem como demais índices zootécnicos como taxa de prenhes e incidência de verminoses. Estas características resultam em menor retorno econômico e maiores emissões de GEE (AIDAR; KLUTHCOUSKI, 2003).

$\mathrm{Na}$ agricultura, a degradação do solo também ocasiona prejuízos econômicos e ambientais. A baixa produtividade de grãos por hectare, maior incidência de pragas e doenças, lixiviação e perdas de minerais do solo, entre outros problemas conduzem a uma maior necessidade de utilização de agrotóxicos e de adubação e correção do solo, necessidades estas que emitem mais GEE e outros poluentes (Macedo, 2009).

\subsubsection{Evolução dos Principais Acordos Globais Sobre o Meio Ambiente}

A partir da Conferência das Nações Unidas Sobre o Meio Ambiente Humano, em 1972, gradualmente ocorreu a intensificação do debate sobre a preservação dos recursos naturais e do meio ambiente. Esta subseção é dedicada a formalizar a cronologia e apresentar as principais conferências, acordos e demais ações realizadas em âmbito global sobre a questão ambiental.

\section{- Conferência das Nações Unidas Sobre o Meio Ambiente Humano - 1972}

Realizada em Estocolmo na Suécia, obteve participação de 113 países e de 250 organizações não governamentais (ONGs) e da ONU. Como resultado da Conferência houve a criação da Declaração sobre o Meio Ambiente Humano. Nesta Declaração foi apontada a necessidade de sinergia entre o meio-ambiente natural e as transformações do ser-humano, valorizando ambas para a vida humana, reconhecendo que a poluição causada pelo serhumano ao meio ambiente pode esgotar os recursos naturais e prejudicar a qualidade de vida. A carta salienta que os países devem atuar de modo a diminuir a disparidade do desenvolvimento entre as nações, procurando no interim amenizar os danos ambientais. Além 
destes pontos gerais, são apontados 26 princípios essenciais para o ser-humano com o meio ambiente (BRASIL, 2012).

- Comissão Mundial Sobre Meio Ambiente e Desenvolvimento (CMED) - 1983 a 1986

Esta Comissão foi criada para avaliar a evolução do cenário ambiental após dez anos das propostas de Estocolmo, como resultado dos primeiros três anos de debate, o Relatório Nosso Futuro Comum ou Relatório de Brundtland (BRASIL, 2012). Este Relatório abordou de maneira mais ampla a questão ambiental, com um documento de 430 páginas, tratou de alarmar sobre a nocividade dos gases do "efeito estufa" e também da destruição da camada de ozônio. Este também abordou a necessidade de conciliação de crescimento econômico e preservação do meio ambiente, segundo trecho do Relatório: "Agora temos de nos preocupar com os impactos do desgaste ecológico - degradação dos solos, regimes hídricos, atmosfera e florestas - sobre nossas perspectivas econômicas" (COMISSÃO MUNDIAL SOBRE MEIO AMBIENTE E DESENVOLVIMENTO, p. 5, 1991). O Relatório trás a primeira definição de desenvolvimento sustentável: “(...) desenvolvimento sustentável - de garantir que ele atenda as necessidades do presente sem comprometer a capacidade de as gerações futuras atenderem também às suas.” (COMISSÃO MUNDIAL SOBRE MEIO AMBIENTE E DESENVOLVIMENTO, p. 9, 1991).

Em geral, a incompatibilidade com o ritmo de crescimento da população e os padrões de consumo são temas abordados, salientando que até mesmo com os avanços tecnológicos, devem ser observados os riscos à saúde do ser humano e do ambiente:

\footnotetext{
"As tecnologias emergentes prometem maior produtividade, mais eficiência e menos poluição, mas muitas apresentam o risco de novos produtos químicos e rejeitos tóxicos de graves acidentes que superam em natureza e proporções os atuais mecanismos para enfrenta-los" (COMISSÃO MUNDIAL SOBRE MEIO AMBIENTE E DESENVOLVIMENTO, p. 18, 1991).
}

\section{- Cúpula da Terra/Rio-92 - 1992}

Realizada na cidade do Rio de Janeiro no Brasil, contou com aproximadamente 1.400 ONGs e 10.000 participantes, dentre estes, 116 chefes de Estado (BRASIL, 2012). A reunião fomentou discussões sobre a degradação ambiental e o desenvolvimento sustentável, fortalecendo este último conceito lançado no Relatório Nosso Futuro Comum. Deste encontro foram resultantes cinco documentos: Agenda 21, a Convenção sobre a diversidade Biológica, 
a Convenção-Quadro sobre Mudança do Clima e a Declaração sobre Florestas. Uma comissão foi designada para acompanhar o desenvolvimento dos trabalhos a cerca dos documentos gerados, a Comissão de Desenvolvimento Sustentável, no âmbito do Conselho Econômico e Social (ECOSOC) (TRIPOLI, 2013). De acordo com Tripoli (p. 5-6, 2013) os principais aspectos dos documentos criados são:

"A Agenda 21 constitui uma cartilha de ações a serem
desenvolvidas principalmente pelos Governos, com vistas à
conciliaçãa entre desenvolvimento e proteção ambiental. A
Convenção sobre a Diversidade Biológica (CDB) reconhece a
importância da diversidade biológica para a evolução e
manutenção da biosfera e aponta as estratégias de proteção da
biodiversidade. A Convenção-Quadro sobre Mudança do
Clima dispõe sobre a estabilidade das concentrações de gases
de efeito estufa na atmosfera, num nível que reduza a
interferência antrópica perigosa no sistema climático. A
Declaração sobre Florestas trata do uso sustentável de florestas
(GANEM, 2012)."

Em sequência à Rio-92 foram realizadas duas outras Conferências das Nações Unidas sobre Desenvolvimento Sustentável, em 2002 na África do Sul e em 2012 no Rio de Janeiro. Apesar dos avanços nas discussões sobre a questão climática, a necessidade de preservação do meio ambiente e maior experiência em tratados internacionais sobre a preservação ambiental, a Rio+20 ainda esbarra nos mesmos pontos da primeira Conferência:

\begin{abstract}
"garantir um compromisso renovado em nome do desenvolvimento sustentável, avaliando o progresso obtido até o presente e as lacunas remanescentes na implementação dos resultados das maiores cúpulas de desenvolvimento sustentável, abordando desafios novos e emergentes. O foco da Conferência incluirá os seguintes temas a serem discutidos e aperfeiçoados durante o processo preparatório: economia verde no contexto do desenvolvimento sustentável e erradicação da pobreza, e o arcabouço institucional para o desenvolvimento sustentável" (TRIPOLI, p. 14, 2013).
\end{abstract}

\title{
- $\quad 3^{\text {a }}$ Conferência das Partes - 1997
}

A $3^{\text {a }}$ Conferência das Partes (COP-3) sediada em Quioto no Japão ficou mais conhecida pela primeira tentativa de um acordo global concreto de compromissos e metas para a preservação do meio ambiente, sobretudo para a redução de emissão de GEE (BRASIL, 2012).

Gerado em 1997 na COP-3 o Protocolo de Quioto só foi ratificado em 16/02/2005 após a assinatura de pelo menos 55\% dos países membros, que também deveriam representar no mínimo 55\% das emissões de GGE do ano de 1990. O compromisso firmado envolveu a redução de emissões de GEE entre 2008-2012 em 5\% do observado em 1990 e para 2013- 
2020 uma diminuição mínima de 18\%, também em relação a 1990 (MINISTÉRIO DO MEIO AMBIENTE, 2017).

Para o atendimento das metas do Protocolo de Quioto foram criados três mecanismos: Comércio de Emissões, Implementação Conjunta e Mecanismo de Desenvolvimento Limpo. Um dos mecanismos de maior destaque no lançamento eram os "créditos de carbono", transformando as reduções de GEE em um título comercializável (MINISTÉRIO DO MEIO AMBIENTE, 2017). Ainda que elaborados os mecanismos e ratificado o documento, em avaliação dos dez anos após o Protocolo de Quioto constatou-se o fracasso do acordo, dado um incremento nas emissões de GEE em 16,2\% de 2005 a 2012 (TUFFANI, 2015).

\section{- $\quad 15^{\mathrm{a}}$ Conferência das Partes - 2009}

Esta Conferência foi realizada em Copenhague na Dinamarca, o resultado em termos da geração de um acordo global não foi positivo, resultando em um documento de apenas 12 parágrafos. Mesmo assim, a partir desta Conferência o Brasil firmou um compromisso voluntário para a redução da emissão de GEE entre 36,1\% e 38,9\% até 2020 (BRASIL, 2012; MINISTÉRIO DA AGRICULTURA PECUÁRIA E ABASTECIMENTO, 2012).

A Política Nacional de Mudança do Clima (PNMC), criada em 2009 através da Lei ${ }^{\circ}$ 12.187, concebeu de acordo com o artigo $3^{\circ}$ do Decreto 7.390/2010, o Plano Setorial de Mitigação e de Adaptação às Mudanças Climáticas para a Consolidação de uma Economia de Baixa Emissão de Carbono na Agricultura (Plano ABC) para atuação no período de 2010 até 2020. Os objetivos do Plano ABC estão direcionados para o desenvolvimento de ações para mitigação de emissões de GEE, bem como melhoria da qualidade de solos, recuperação de áreas degradadas, redução do desmatamento, fixação de biomassa e tratamento de dejetos, realizados através do incentivo a adoção de sistemas produtivos agropecuários mais sustentáveis e eficientes. Para a execução do Plano ABC elaborou-se o então Programa para a Redução da Emissão de Gases de Efeito Estufa na Agricultura (Programa ABC), um programa de crédito associado ao Crédito Rural, com taxas de juros subsidiadas (MINISTÉRIO DA AGRICULTURA PECUÁRIA E ABASTECIMENTO, 2012). O Plano e Programa ABC serão detalhados na seção posterior deste texto.

\section{- $\quad 21^{\mathrm{a}}$ Conferência das Partes - 2015}

Com a presença em Paris das 195 partes da Convenção-Quadro das Nações Unidas sobre Mudança do Clima (UNFCCC) e da União Europeia, foi ratificado acordo no compromisso de manter a temperatura da Terra em $2{ }^{\circ} \mathrm{C}$ abaixo dos níveis pré-industriais, com 
maiores esforços no sentido de limitar o incremento de temperatura em $1,5^{\circ} \mathrm{C}$ acima da temperatura média pré-industrial. O documento produzido na COP-21, além de fortalecer as ações anteriores a 2020, trás importantes diretrizes sobre a mitigação de emissões de GEE, a transferência e desenvolvimento de tecnologias sustentáveis, a estrutura de financiamento para a realização do acordo, ações de transparência do progresso com as metas ambientais, entre outros compromissos que abrangem majoritariamente até o ano de 2030 (ORGANIZAÇÃO DAS NAÇÕES UNIDAS, 2015).

No caso brasileiro a ratificação da COP-21 exprimiu a adoção efetiva da sua pretendida Contribuição Nacionalmente Determinada (intented Nationally Determined Contribution - iNDC), portanto, perde o status de pretendida para tornar-se definitiva (NDC). Esta Contribuição em consonância com as decisões da COP-19 e COP-20, foi gerada em 2015 e está focada em diversos pontos, mas essencialmente tem como metas a mitigação de GEE, ações em adaptação e determinação de meios de implementação para atingir os objetivos da COP-21 (BRASIL, 2015).

As recomendações do IPCC para que exista a possibilidade de limitar a temperatura abaixo de $2^{\circ} \mathrm{C}$ em comparação aos níveis pré-industriais incluem a ampliação da utilização da bioenergia, atuação sobre o padrão de mudança de uso da terra e florestas e incrementar em pelo menos quatro vezes a matriz energética mundial com fontes de baixa emissão de GEE até 2050 (BRASIL, 2015).

Além das recomendações do Intergovernmental Panel on Climate Change (2014), o Brasil se comprometeu através da NDC em atingir as seguintes metas até 2030: ampliar a participação na matriz energética nacional da bioenergia sustentável para cerca de $18 \%$; robustecer o Código Florestal e ampliar os sistemas de manejo sustentável de florestas nativas, tendo em vista atingir o desmatamento ilegal zero na Amazônia; compensação das emissões de GEE oriundas do desmatamento legal e reflorestamento de 12 milhões de hectares; ampliar a participação das energias renováveis na matriz energética brasileira para $45 \%$, incluindo aumentar a eficiência do setor elétrico em 10\%; ampliar o uso de fontes renováveis (além da hídrica) na matriz energética total para uma parcela de 28 a 33\%; apoiar o Plano ABC como estratégia para o desenvolvimento sustentável no setor rural, adicionando as metas do Plano a recuperação de 15 milhões de hectares de pastagens degradadas e 5 milhões de hectares de integração Lavoura-Pecuária-Floresta; implementar novas tecnologias limpas e incrementar a eficiência energética de baixo carbono no setor industrial; e, finalmente, melhorar a qualidade de infraestrutura de transporte público em área urbanas, visando a eficiência ambiental. 


\subsubsection{Instrumentos de Preservação Ambiental}

A crescente preocupação com os problemas ambientais e climáticos acompanhou a ampliação dos instrumentos de preservação. Ao se tratar de regulamentação e legislação ambiental, dois instrumentos são comumente utilizados: o comando e controle (CEC) e instrumentos econômicos ou de mercado (IM) (MARGULIS, 1996).

Os instrumentos do gênero CEC são regulamentações, normas, regras, padrões que devem ser seguidos pelos agentes econômicos. Estes instrumentos são mais eficientes quando as instituições e órgãos de controle são capazes de garantir que as ações de CEC sejam cumpridas. Exemplos de políticas de CEC são: licenças para instalação de certas atividades, zoneamentos exprimindo regras de ocupação em determinada região/área, padrões de qualidade, padrões de concentração de poluentes, entre outros (MARGULIS, 1996). No caso brasileiro, o Código Florestal e políticas como o Cadastro Ambiental Rural são exemplos de instrumentos de CEC.

Instrumentos de CEC normalmente são pouco flexíveis e não observam os prejuízos econômicos que podem ocasionar as empresas. Os IMs tendem a corrigir esta miopia, valendo-se do Princípio Poluidor Pagador (PPP), aufere que os poluidores assumam os custos para reduzir a poluição ou dano ambiental ao desejável pela instituição pública. Dentre os instrumentos utilizados estão os sistemas de depósito e reembolso, subsídios, criação de mercado (como os créditos de carbono), entre outros (MARGULIS, 1996).

Subsídios para adoção de práticas ambientalmente mais favoráveis são instrumentos amplamente utilizados pelo mundo, como os Pagamentos por Serviços Ambientais (PSA). O PSA consiste em repasses monetários aos indivíduos de forma a "compensar" a redução da produção, eficiência ou competitividade por restringir a utilização de recursos naturais em prol de oferecer "Serviços Ambientais". Estes "serviços" contemplam amplo espectro de "benefícios" como preservação da biodiversidade, melhoria da qualidade do ar e da água, controle de erosões, entre outros. Diversos países fazem uso de programas de PSA como a Austrália, Colômbia, Costa Rica, Equador, Estados Unidos, França e México. A Costa Rica é pioneira na formulação e implementação de políticas de PSA para proteger e preservar as florestas (FOLETO; LEITE, 2011).

Do ponto de vista dos instrumentos de preservação ambiental, o Programa ABC constitui-se num IM, no entanto, não se assemelha a estratégias do gênero dos PSA. Ao invés de pagar por "Serviços Ambientais", o Programa ABC oferece crédito subsidiado para proporcionar a implementação de novas tecnologias de baixa emissão de carbono para a 
agricultura. Segundo o Plano ABC as atividades financiadas também são economicamente mais atrativas, aumentando a eficiência e produtividade dos empreendimentos agropecuários, que como externalidades propiciam uma redução na emissão de GEE. O Programa ABC ao proporcionar um Plano para toda a extensão territorial brasileira, com imenso volume de recursos e especificamente para proporcionar inovação tecnológica conduzindo a um manejo voltado para agricultura de baixa emissão de carbono constitui-se numa estratégia pioneira.

\subsection{O Plano e Programa ABC}

Nesta seção expõem-se as metas e ações propostas pelo Plano ABC para agropecuária brasileira no período de 2010-2020, bem como as regras, prazos, taxas de juros e linhas de empréstimos do Programa ABC. As características específicas dos sistemas agrícolas de baixa emissão de carbono e trabalhos de avaliação sobre o Plano e Programa ABC também são retratados nesta seção.

\subsubsection{Plano $A B C^{2}$}

Derivado da Política Nacional sobre Mudança do Clima (PNMC), o Plano ABC criado de acordo com o artigo $3^{\circ}$ do Decreto 7.390/2010, tem vigência de 2010 até 2020. Este é o documento que fornece as diretrizes para a adoção de tecnologia sustentáveis para a produção agropecuária, de maneira a proporcionar o cumprimento do acordo voluntário de redução de emissões de Gases do Efeito Estufa (GEE) firmado na COP-15 em 2009. O Plano tem como objetivos específicos:

- Contribuir para o cumprimento dos compromissos de redução da emissão de GEE assumidos voluntariamente pelo Brasil, assumidos na COP-15;

- Garantir a modernização e sustentabilidade do manejo agropecuário no território brasileiro de modo a reduzir a emissão dos GEE bem como ampliar a fixação atmosférica de $\mathrm{CO}_{2}$ na vegetação e no solo;

- Incentivar a adoção de Sistemas de Produção Sustentáveis que visem a redução de emissões de GEE, melhoria em aspectos sociais e da renda da agropecuária nacional, principalmente através destas tecnologias: Recuperação de Pastagens Degradadas;

2 Esta seção tem como referência o documento do Plano ABC do Ministério da Agricultura Pecuária e Abastecimento (2012). 
Integração Lavoura-Pecuária-Floresta (iLPF) e Sistemas Agroflorestais (SAFs); Sistema Plantio Direto (SPD); Fixação Biológica do Nitrogênio (FBN); e Florestas Plantadas;

- Incentivar o uso de Tratamento de Dejetos Animais para geração de biogás e de composto orgânico;

- Incentivar os estudos e a aplicação de técnicas de adaptação de plantas, de sistemas produtivos e de comunidades rurais aos novos cenários de aquecimento atmosférico, em especial aqueles de maior vulnerabilidade; $\mathrm{e}$

- Promover esforços para reduzir o desmatamento de florestas decorrente dos avanços da pecuária e de outros fatores.

Através dos objetivos é possível desagregar várias frentes de atuação, cada qual deve ser inserida de acordo com a estrutura socioeconômica e ambiental da região, tendo em vista a grande diversidade climática, do solo, econômica e enorme extensão do território nacional. Estas características elevam a heterogeneidade da adaptação dos sistemas produtivos inovadores às regiões brasileiras. Portanto, o Plano ABC possui sete programas:

- Recuperação de Pastagens Degradadas (RPD);

- Integração Lavoura-Pecuária-Floresta (iLPF) e de Sistemas Agroflorestais (SAFs);

- Sistema Plantio Direto (SPD);

- Fixação Biológica do Nitrogênio (FBN);

- Florestas Plantadas (FLP);

- Tratamento de Dejetos Animais (TDA); e

- Adaptação às Mudanças Climáticas.

Os subprogramas devem ser implementados para atingir as seguintes metas ${ }^{3}$ :

- Recuperação de 15 milhões de hectares de pastagens degradadas;

- Ampliação da adoção de iLPF em 4 milhões de hectares;

- Expansão da adoção do SPD em 8 milhões de hectares;

- Expansão da adoção da FBN em 5,5 milhões de hectares de áreas de cultivo, em substituição ao uso de fertilizantes nitrogenados;

- Expansão do plantio de florestas em 3,0 milhões de hectares; e

- Ampliação do uso de tecnologias para tratamento de 4,4 milhões de $\mathrm{m}^{3}$ de dejetos animais.

3 Cabe destacar que de acordo com a proposta do Brasil (2015) ratificada em 2016 após a COP-21, a RPD deve ser acrescida de 15 milhões de hectares e a implantação de iLPF em 5 milhões de hectares, ambos até 2030. 
As ações previstas para alcançar as metas e os objetivos do Plano abrangem uma vasta gama de atividades como: campanhas publicitárias, capacitação de técnicos e produtores rurais, transferência de tecnologia, regularização ambiental e fundiária, Assistência Técnica e Extensão Rural (Ater), estudos e planejamento, Pesquisa, Desenvolvimento \& Inovação (PD\&I), disponibilização de insumos, produção de sementes e mudas florestais e por fim o crédito rural $^{4}$. Somando todas estas ações, a proposta inicial do Plano previa um orçamento de 197 bilhões de reais.

O monitoramento das ações deverá ser realizado de acordo com a Convenção-Quadro das Nações Unidas sobre Mudança do Clima (CQNUMC), conforme os artigos números 60 e 62, definidos na COP-16 em Cancun. Estes artigos do acordo preveem que as ações tomadas para a mitigação de emissões de GEE, bem como seus efeitos, devem ser organizados e adicionados ao inventário nacional de emissão e da comunicação social, devendo ser apresentado a CQNUMC com periodicidade de 4 anos. Adicionalmente, relatórios interinos poderão ser apresentados a CQNUMC a cada 2 anos. Este modelo visa garantir a isonomia e transparência do monitoramento, fazendo possível a verificação dos efeitos das políticas periodicamente a nível internacional.

A estrutura de monitoramento, reporte e verificação (MRV) deve delimitar uma descrição do cenário base (2010 a 2012) para possibilitar a verificação dos resultados obtidos com as ações até 2020. Deve ser criada metodologia para cálculo das mitigações, possibilitando a verificação dos resultados internacionalmente. $\mathrm{O}$ principal indicador a ser utilizado para a acompanhamento do progresso do Plano $\mathrm{ABC}$ é a área em que foram implementados os novos sistemas produtivos.

\subsubsection{Programa $A B C^{5}$}

O Programa ABC é a linha de Crédito Rural destinada ao cumprimento do Plano ABC. O Crédito Rural tem como objetivo fornecer ao setor rural (pecuário ou agrícola), inclusive as indústrias de beneficiamento, crédito para o custeio, investimento ou comercialização da produção, de maneira a fortalecer todo o setor, propiciando melhor uso da terra e geração de renda. De acordo com a Resolução 3.979, art. $1^{\circ}$ o Programa $\mathrm{ABC}$ tem

\footnotetext{
$4 \mathrm{O}$ Programa $\mathrm{ABC}$ é o mecanismo criado para realizar as operações de crédito rural direcionadas ao cumprimento do Plano ABC.

5 Esta seção tem como referência o documento do Programa ABC do Banco Central Brasileiro (2016).
} 
como beneficiários os produtores rurais e cooperativas (inclusive repasse a associados) e seus objetivos são:

- Reduzir as emissões de gases de efeito estufa oriundas das atividades agropecuárias;

- Reduzir o desmatamento;

- Aumentar a produção agropecuária em bases sustentáveis;

- Adequar as propriedades rurais à legislação ambiental;

- Ampliar a área de florestas cultivadas

- Estimular a recuperação de áreas degradadas.

Este Programa é composto por nove subprogramas, definidos pela Resolução 4.105, art. $6^{\circ}$ e um subprograma regido pela Resolução 4.488 art. $4^{\circ}$ (ABC Bioma Amazônia):

1. Recuperação de pastagens degradadas (ABC Recuperação);

2. Implantação e melhoramento de sistemas orgânicos de produção agropecuária (ABC Orgânico);

3. Implantação e melhoramento de sistemas de plantio direto "na palha" (ABC Plantio Direto);

4. Implantação e melhoramento de sistemas de integração lavoura-pecuária, lavourafloresta, pecuária-floresta ou lavoura-pecuária-floresta e de sistemas agroflorestais (ABC Integração);

5. Implantação, manutenção e melhoramento do manejo de florestas comerciais, inclusive aquelas destinadas ao uso industrial ou à produção de carvão vegetal (ABC Florestas);

6. Adequação ou regularização das propriedades rurais frente à legislação ambiental, inclusive recuperação da reserva legal, áreas de preservação permanente, recuperação de áreas degradadas e implantação e melhoramento de planos de manejo florestal sustentável (ABC Ambiental);

7. Implantação, melhoramento e manutenção de sistemas de tratamento de dejetos e resíduos oriundos da produção animal para a geração de energia e compostagem (ABC Tratamento de Dejetos);

8. Implantação, melhoramento e manutenção de florestas de dendezeiro, prioritariamente em áreas produtivas degradadas ( $\mathrm{ABC}$ Dendê);

9. Estímulo ao uso da fixação biológica do nitrogênio (ABC Fixação); 
10. Implantação, melhoramento e manutenção de plantações de açaí e de cacau no bioma Amazônia, desde que observada as condições de que trata o MCR 2-1-12 (ABC Bioma Amazônia).

As Resoluções 4.105 , art. $6^{\circ}$ e 4.488 art. $4^{\circ}$ delimitam a finalidade do crédito para o investimento. Desta finalidade, a Resolução 3.979, art. $1^{\circ}$ indica as atividades financiáveis:

- A elaboração de projeto técnico e georrefereciamento das propriedades rurais, inclusive das despesas técnicas e administrativas relacionadas ao processo de regularização ambiental;

- Assistência técnica necessária até a fase de maturação do projeto;

- Realocação de estradas internas das propriedades rurais para fins de adequação ambiental;

- Aquisição de insumos e pagamentos de serviços destinados a implantação e manutenção dos projetos financiados;

- Pagamento de serviços destinados à conversão da produção orgânica e sua certificação;

- Aquisição, transporte, aplicação e incorporação de corretivos agrícolas (calcário e outros);

- Marcação e construção de terraços e implantação de práticas conservacionistas do solo;

- Adubação verde e plantio de cultura de cobertura do solo;

- Aquisição de sementes e mudas para formação de pastagens e de florestas;

- Implantação de viveiros de mudas florestais;

- Operações de destoca;

- Implantação e recuperação de cercas, aquisição de energizadores de cerca, aquisição, construção ou reformas de bebedouros e de saleiro ou cochos de sal;

- Construção e modernização de benfeitorias e de instalações, na propriedade rural;

- Despesas relacionadas ao uso de mão-de-obra própria, desde que compatíveis com estruturas de custos de produção regional (coeficiente técnico, preço e valor), indicadas por instituições oficiais de pesquisa ou de assistência técnica (federal ou estadual). Para tal, se faz necessária a comprovação da aplicação dos recursos feita mediante apresentação de laudo de assistência técnica oficial; 
Além dos itens financiáveis relacionados a finalidade de investimento pela Resolução 3.979, art. $1^{\circ}$, a Resolução 4.105, art. $6^{\circ}$ e a Resolução 4.338, art. $7^{\circ}$ relacionam respectivamente:

- A aquisição de máquinas, implementos e equipamentos de fabricação nacional, inclusive para a implantação de sistemas de irrigação, para a agricultura e pecuária, biodigestores, máquinas e equipamentos para a realização da compostagem e para produção e armazenamento de energia, limitados a $40 \%$ (quarenta por cento) do valor financiado. A exceção do item relacionado no MCR 13-7-1-“c”- VII, cujo limite de financiamento pode ser de até $100 \%$ (cem por cento) do valor do projeto a ser financiado.

- A aquisição de bovinos, bubalinos, ovinos e caprinos, para reprodução, recria e terminação, e sêmen, óvulos e embriões dessas espécies, limitada a 40\% (quarenta por cento) do valor financiado.

Em caso de custeio associado ao investimento a Resolução 3.979, art. $1^{\circ}$ determina que este item possa ser financiado por até $30 \%$ do valor total. É admitida ampliação do valor para 35\% se destinado para implantação e à manutenção de florestas comerciais, recomposição de áreas de preservação permanente ou de reserva legal. Ampliação para até $40 \%$ do valor é permitida para a aquisição de bovinos, ovinos e caprinos, para reprodução, recria e terminação e sêmen dessas espécies.

Dos limites do crédito por ano agrícola são 2,2 milhões de reais por beneficiário (Resolução 4.486 art. $6^{\circ}$ ) com adição para 3 milhões de reais em caso de implantação de florestas comerciais para produtores com até 15 módulos fiscais e, para 5 milhões de reais caso o produtor possuir mais de 15 módulos fiscais (Resolução 4.421 art. $8^{\circ}$ ).

De acordo com a Resolução 4.486 art. $6^{\circ}$ a taxa efetiva de juros ${ }^{6}$ é de 8,5\% a.a. para operações contratadas a partir de 1\%/7/2016 e de $8 \%$ a. a. para produtores beneficiários do Programa Nacional de Apoio ao Médio Produtor Rural (Pronamp).

A liberação do crédito ocorre em parcelas, conforme o cronograma do projeto e reembolso, em parcelas semestrais ou anuais, definido de acordo com o projeto técnico e com fluxo de receitas da propriedade beneficiada, conforme a Resolução 3.979 art. $1^{\text {o: }}$ :

6 A taxa de juros, limites, prazos e carência sofreram algumas alterações ao longo do tempo, sendo contempladas no texto as mais atuais. A taxa de juros no primeiro ano safra (2010/11) foi de 5,5\% a.a., mantevese no segundo ano safra, situou-se em 5\% a. a. para o terceiro e quarto, no quinto foi estabelecida em $5 \%$ a. a. ou $4,5 \%$ a. a. para médios produtores, no sexto ano fora para $8 \%$ a. a. e 7,5\% a. a. no caso de médios produtores, por fim, o sétimo ano que é contemplado no corpo do texto. 
1. Até 5 anos, com até 24 meses de carência, quando o crédito for destinado à implantação de viveiros de mudas florestais;

2. Até 8 anos, com até 36 meses de carência, quando se tratar de investimentos destinados à adequação ao sistema de agricultura orgânica e à recuperação de pastagens e de sistemas produtivos de integração lavoura-pecuária, lavoura-floresta, pecuária-floresta ou lavoura-pecuária-floresta. $\mathrm{O}$ prazo pode ser estendido a até 12 anos quando a componente florestal estiver presente;

3. Até 12 anos, com carência de até 8 anos, não podendo ultrapassar 6 meses da data do primeiro corte, quando se tratar de projetos para implantação e manutenção de florestas comerciais e para produção de carvão vegetal. O prazo pode ser estendido para até 15 anos a critério da instituição financeira e quando a espécie florestal assim o justificar, podendo também a carência ser estendida ao pagamento dos juros, desde que previsto no projeto;

4. Até 15 anos, com carência de até 12 meses, quando se tratar de projetos para recomposição e manutenção de áreas de preservação permanente ou de reserva legal;

5. Até 12 anos, com carência de até anos, quando se tratar de projetos para implantação e manutenção de florestas de dendezeiro;

Ainda do reembolso, a Resolução 4.124 art. $6^{\circ}$ estabelece prazo de até 10 anos, com carência de até 5 anos, de acordo com o projeto, para as demais finalidades não enquadráveis nas alíneas anteriores.

De todos os aspectos técnicos do Programa $\mathrm{ABC}$ descritos pelo Banco Central Brasileiro (2016) a respeito da criação das linhas de empréstimos, taxas de juros, finalidades para investimento, limites e prazos, destacam-se a criação das linhas ABC Orgânico, ABC Dendê e ABC Bioma Amazônia, que não estão contidas na proposta original do Plano $\mathrm{ABC}$. Não fica claro o enquadramento destas linhas nas metas operacionais do Plano, ainda que assumindo alguma relação com a implementação das culturas de dendê, açaí e cacau incluídas no ABC Dendê e Bioma Amazônia - às linhas de florestas plantadas, recuperação de pastagens degradadas ou até mesmo a adaptação às mudanças climáticas contempladas no Plano, a representatividade destas culturas no total produzido no Brasil é diminuta. Utilizando os dados do Instituto Brasileiro de Geografia e Estatística (2017a) a participação do cacau (em amêndoa) e dendê (cacho de coco) no valor da produção de lavouras permanentes não ultrapassou 7\% em nenhum ano do período de 1994 até 2015 e quanto ao açaí, com dados do Instituto Brasileiro de Geografia e Estatística (2017b) a sua maior participação ocorreu em 2015 com aproximadamente 10,2\% do valor da produção da extração vegetal e da silvicultura, 
sendo ambas as porcentagens diminutas para justificar uma linha à parte no Programa $\mathrm{ABC}$. Quanto ao ABC Orgânico, à adoção de técnicas livres de agrotóxicos, adubação e produtos químicos parece se enquadrar na agricultura de baixo carbono, mas tanto sua expressividade é pequena em relação à agricultura tradicional, quanto seus padrões produtivos não são realistas para atender a crescente demanda de alimentos.

\subsubsection{Definições das Técnicas Inseridas no Plano e Programa ABC}

A proposta realizada pelo Plano ABC apresentava sete subprogramas para a realização dos objetivos traçados, que foram transformados em dez linhas de financiamento aplicáveis no Programa ABC. Destas linhas de financiamento, algumas são facilmente inteligíveis através da proposta do Plano ABC e do conteúdo no Programa ABC, no entanto, técnicas como a Fixação Biológica de Nitrogênio, integração Lavoura-Pecuária-Floresta, Recuperação de Pastagens Degradadas, Sistema de Plantio Direto e Tratamento de Dejetos Animais contém diversas especificidades, cabendo uma rápida definição do que é representado por estas técnicas para melhor entendimento dos objetivos do Plano e Programa ABC.

\section{- Fixação Biológica de Nitrogênio (FBN)}

O nitrogênio por ser um aminoácido e ácido nucleico é um dos principais nutrientes para a produtividade das culturas vegetais. Mesmo sendo o componente mais abundante na composição da atmosfera terrestre sua disponibilidade no solo é limitada e são poucos os cultivos que tem capacidade de fixar nitrogênio no solo. A maioria das plantas apenas retira os recursos de nitrogênio, tornando o solo pouco fértil de maneira relativamente rápida. Como as plantas não possuem capacidade de utilizar o nitrogênio atmosférico, este nitrogênio deve ser convertido para o solo, usualmente através da adubação orgânica, adubação com a amônia ou utilização de leguminosas, as quais tem a potencialidade de atribuir nitrogênio ao solo (LOPES; MORAES; LANG, 2016).

A adubação orgânica é dificultada em grandes extensões de terra, sendo assim a fertilização com a amônia é mais utilizada. O processo produtivo da amônia é altamente poluente devido à exigência de elevada pressão e temperatura e seu uso é pouco eficiente. Raramente as plantas absorvem quantias superiores a $50 \%$ da quantidade fertilizada por amônia, extraviando o recurso em forma de gases ou por lixiviação, contribuindo assim para a 
emissão de GEE ou à poluição de recursos hídricos como rios e lençóis freáticos (HUNGRIA; MENDES; MERCANTE, 2013).

A FBN é um processo menos poluente e eficiente para a incorporação do nitrogênio atmosférico $\left(\mathrm{N}_{2}\right)$ no solo. Através da inoculação de bactérias do gênero da Rhizobiaceae em conjunto com as leguminosas, a simbiose destes organismos propicia a conversão do nitrogênio atmosférico em amônia $\left(\mathrm{N}_{2}\right.$ para $\left.\mathrm{NH}_{3}\right)$. No Brasil este procedimento é amplamente utilizado para o cultivo de soja (HUNGRIA; MENDES; MERCANTE, 2013).

\section{- Integração Lavoura-Pecuária-Floresta (iLPF)}

Os sistemas de integração consistem na geração de novas modalidades de plantio e uso da terra, de forma a conduzir a produção agrícola, animal e florestal através de consórcio, sucessão ou rotação. De acordo com Embrapa (2011) existem quatro modalidades de sistemas de integração ${ }^{7}$ : a integração Lavoura-Pecuária que combina elementos de lavoura (culturas temporárias e pastagens) e pecuária, integração Pecuária-Floresta com consórcio de pecuária (pastagens) e culturas florestais, integração Lavoura-Floresta entre culturas temporárias e florestas e, por fim, a integração Lavoura-Pecuária-Floresta que integra elementos de lavoura temporárias, pecuária e floresta.

A implantação dos sistemas de integração pode ocorrer de diferentes maneiras, Kichel et al. (2014) aponta: a agricultura inserida nas pastagens (como para a produção de silagem com sorgo ou milho), as pastagens introduzidas na lavoura (rotacionando o cultivo, melhorando a qualidade do solo) e florestas incluídas nas pastagens e/ou lavouras (sombreamento e conforto térmico para certas culturas e animais, bem como as culturas de ciclo mais rápido amortizando os custos da implantação de florestas).

A inserção das culturas em cada sistema representa uma dinâmica diferente, já que cada uma das culturas tem tempo específico para a maturação. Por exemplo, enquanto o componente florestal pode demorar até 12 anos para a colheita, a pecuária pode ocupar a área por períodos curtos como 3 a 5 meses (EMBRAPA, 2011). O modelo de integração escolhido é fortemente correlacionado ao clima e solo. Em áreas de solo mais fértil, opta-se pela cultura majoritariamente de grãos, com a utilização da pecuária em períodos reduzidos, valendo-se da maior produtividade das pastagens aproveitando o preparo do solo dos cultivares, além de servir como palhada para o plantio direto da próxima lavoura. Em regiões onde a pecuária extensiva é mais favorável (solo mais pobre, restrição tecnológica, de capital, infraestrutura,

$7 \mathrm{O}$ autor destaca que a nomenclatura de integração é mais abrangente que a dos SAFs respectivos (Agropastoril, Silvipastoril, Silviagrícola e Agrossilvipastoril). 
etc.) a lavoura pode ser ferramenta importante para a recuperação das pastagens com amortização de custos, bem como produção de silagem para os animais (KICHEL et al., 2014).

\section{- Recuperação de Pastagens Degradadas (RPD)}

A pastagem pode ser considerada degradada ou de baixa produtividade por aspectos agrícolas e/ou biológicos. De acordo com Dias Filho (2014) a degradação agrícola ocorre ao se fazer presente um aumento da população de plantas daninhas e pragas, prejudicando a qualidade da pastagem. A degradação biológica ocorre quando o solo perde a capacidade de manter a cobertura vegetal, gerando, portanto o predomínio de plantas daninhas (menos exigentes em termos de nutrientes) e solo descoberto. A degradação ocasiona redução da qualidade da pastagem e da cobertura vegetal sem possibilidades de reversão natural, reduzindo a matéria orgânica e nutrientes disponíveis para os animais. Como resultado, as pastagens de baixa produtividade apresentam maiores emissões de GEE tanto pela menor cobertura vegetal quanto pela menor produtividade animal.

O processo de degradação da pastagem acontece no trato inadequado do solo. A utilização de forrageira não adaptada para o solo e clima, manutenção de elevada taxa de lotação de animais por hectare e falta de adubação de manutenção, são algumas razões para a degradação da pastagem.

De acordo com (ZIMMER et al., 2012) a recuperação de pastagens pode ser realizada de maneira direta fazendo uso de implementos mecânicos, insumos químicos e técnicas agronômicas ou de maneira indireta valendo-se de uso intermediário de cultivo de lavouras. A maneira de recuperação a ser escolhida depende das características edafoclimáticas, do solo, da disponibilidade de capital, acesso a tecnologia, insumos químicos e mecânicos.

No Plano ABC não ficam definidas as características necessárias para denominar a pastagem como degradada. Este é um grande entrave para a avaliação da concessão de crédito, pois a definição de "degradação", sem nenhum parâmetro, é tênue. Ainda que os aspectos agrícolas e/ou biológicos citados para haver degradação sejam observados, a intensidade destes fenômenos pode variar.

\section{- Sistema de Plantio Direto (SPD)}

O Sistema de Plantio Direto consiste num método sustentável e ao mesmo tempo eficiente. Neste sistema apenas o solo da linha de semeadura é movimentado com a semeação, adubação, até mesmo com a aplicação de agroquímicos, portanto não se realiza a aragem ou 
gradagem para o plantio, conservando o solo coberto com vegetação durante o ano todo. Este sistema de cultivo além de utilizar em menor escala os agroquímicos e combustíveis fosseis, também impede a lixiviação e/ou erosão dos solos, garantindo melhorias nas características físicas, químicas, biológicas e ambientais (FAVARATO et al., 2015).

\section{- Tratamento de Dejetos Animais (TDA)}

O Tratamento de Dejetos Animais utiliza a biomassa produzida pelo rebanho bovino, suíno ou de galináceos na produção de biogás através da fermentação anaeróbica em biodigestores. O biogás ou biocombustível, composto de metano e dióxido de carbono é uma fonte de combustível e energia, gerando economia de recursos energéticos e impedindo que a matéria orgânica proveniente dos excrementos dos animais polua o ar (com o metano e dióxido de carbono), o solo e os recursos hídricos (AQUINO et al., 2014).

\subsubsection{Avaliações Sobre o Plano e Programa ABC}

A implementação do Plano ABC não depende exclusivamente dos recursos monetários viabilizados pelos agentes financeiros através do Programa $\mathrm{ABC}$, outros recursos técnicos e humanos para a geração e difusão de conhecimento sobre a aplicabilidade dos sistemas de manejo incentivados pelo programa, ferramentas de gestão e monitoramento se fazem necessárias para alcançar os objetivos traçados. Do ponto de vista da geração de informações, dados, estatísticas e pesquisas relevantes a introdução e evolução do Plano ABC no território brasileiro, destacam-se as participações da Empresa Brasileira de Pesquisa Agropecuária (EMBRAPA), das Universidades e outras entidades de pesquisa como o Observatório ABC (LARCHER, 2016).

A EMBRAPA é a principal fonte de pesquisas sobre a adaptação das técnicas propostas. Os programas de Assistência Técnica e Extensão Rural (ATER) atuam em conjunto com as Unidades de Referências Tecnológicas (URTs) para implementar experimentos de RPD, SPD, iLPF, FBN, TDA, FLP e demais subprogramas do ABC, testando em regiões de solo, clima e condições edafoclimáticas especificas a eficiência, eficácia, retorno econômico e ambiental de gêneros de forrageiras, gramíneas e árvores, espaçamentos e organização das culturas, entre outras características agronômicas. Todas as pesquisas a este respeito, ainda que essenciais para o sucesso do Plano e Programa ABC desviam-se do escopo deste trabalho. Para mais informações a este respeito sugere-se acessar 
o portal da EMBRAPA $^{8}$, o qual possui a biblioteca de todas as pesquisas publicadas pela instituição.

Paixão e Bacha (2015) no sentido de realizar uma contextualização do crédito concedido e programado para os anos safra de 2010/11 até 2012/13, sem subdivisão de estados ou regiões, encontraram elevada desigualdade na distribuição de contratos por subprogramas, os quais são majoritariamente compostos pela RPD, além de verificarem que o crédito concedido tem se situado abaixo do programado.

Wander, Tomaz e Pinto (2016) apresenta os valores contratados da safra 2011/12 até a safra 2014/15 onde são desagregados os valores totais concedidos pelo ABC por estado. Os autores concluem que há elevada concentração dos contratos do $\mathrm{ABC}$, apontando que os estados de MG, SP, GO, MS, MT, RS e PR contemplam 79,39\% do valor investido.

Magalhães e Lima (2014) avaliam a situação dos recursos programados e desempenhados para as safras de 2010/11 até 2012/13. Os autores indicam que pela lógica de mitigação de GEE os recursos deveriam estar sendo destinados majoritariamente para o Norte, Nordeste e Centro-Oeste, no entanto, as regiões Sul e Sudeste detêm maiores parcelas dos recursos.

Utilizando os estados como amostra, Leal (2016) encontra elevada correlação entre os empréstimos do Programa ABC com as produções agropecuárias, principalmente soja, milho e gado bovino, no entanto, a correlação dos empréstimos com pastagens degradadas é baixa. Os resultados sugerem que o Programa $\mathrm{ABC}$ está sendo desenvolvido nos estados em que as atividades produtivas estão previamente consolidadas.

O Observatório $\mathrm{ABC}$ realizou uma série de relatórios e pesquisas sobre a distribuição dos contratos do Programa ABC, a estrutura institucional, abordagem ambiental e outros temas relacionados. As pesquisas do Observatório ABC $(2013,2014)$ apontam que os desembolsos do Programa ABC situaram-se em patamar inferior ao programado, desde o primeiro ano de vigência até a safra 2013/14. São citadas dificuldades burocráticas ao adquirir contratos do $\mathrm{ABC}$ devido à exigência de projeto técnico atestando o potencial de produtividade e mitigação de GEE, enquanto outras linhas de crédito rural são muito mais simples e rápidas. Os resultados reforçam a aderência desigual dentre os subprogramas do ABC principalmente com o predomínio de contratos em RPD, bem como a concentração dos recursos no Centro-Sul do país, enquanto Norte e Nordeste possuem baixo volume de operações. A criação do Sistema de Operações do Crédito Rural e Proagro (SICOR) em 2013 
é indicada pelo Observatório ABC (2014) como importante ferramenta para a viabilização da caracterização dos contratos por subprogramas e demais desagregações.

Outros relatórios de atualização foram produzidos pelo Observatório $\mathrm{ABC}$, os pontos observados anteriormente se mantiveram. Adicionalmente, a partir da safra 2013/14 o CentroOeste passou a frente do Sudeste na captação de crédito do ABC, tornando-se o estado com maior participação neste quesito. Houve também maior participação do Norte e Nordeste, que chegaram a ultrapassar a participação percentual do Sul em alguns momentos, no entanto, frente às necessidades locais estas regiões deveriam receber volumes de crédito ainda maiores. A necessidade de monitoramento das emissões de GEE é apontada para viabilização de análise mais precisa do Programa ABC (OBSERVATÓRIO ABC, 2014b; c, 2016, 2017)

No sentido da caracterização das áreas prioritárias para o Programa $\mathrm{ABC}$, Barros (2017) realizou uma classificação mesclando indicadores de qualidade das pastagens com o regime hídrico, risco climático, a infraestrutura em transportes e viabilidade econômica das culturas. Concluiu-se que as áreas mais degradadas e de maiores necessidades ambientais são as de maior debilidade econômica e logística, indicando que ações de políticas públicas para a viabilização de contratos com seguro rural poderiam ser realizadas para diminuir estes riscos e incrementar a aderência ao Programa ABC.

Conforme o Observatório ABC (2017b) os recursos necessários para atingir as metas quanto a recuperação de pastagens e iLPF seriam menores do que as previstas no Plano ABC. Ainda assim, o baixo volume de contratação dos recursos disponibilizados encontra-se como um desafio. Segundo o estudo se fossem realizados os investimentos nas áreas prioritárias haveria um custo econômico de aproximadamente $\mathrm{R}$ \$,70 do consumo anual por habitante, enquanto se permitida a livre alocação, ocorreria um ganho de $\mathrm{R} \$ 41,18$. Estima-se que os efeitos indiretos positivos sobre os recursos naturais e meio ambiente são maiores se consideradas as áreas prioritárias. Esta relação econômica exemplifica as dificuldades do Plano e Programa ABC em atingir justamente as áreas de maior potencial de mitigação de GEE. As alocações inter-regionais seriam divergentes nos cenários construídos, em caso de alocação de recursos nas áreas prioritárias o Nordeste absorveria maior parte, enquanto na livre alocação seriam as regiões Sudeste e Sul.

Em avaliação das barreiras para implementação do Programa ABC em 2012, Stabile, Azevedo e Nepstad (2012) indicam como problemas específicos do ABC a fragilidade técnica dos bancos e dos produtores para estabelecer a transição para a agricultura de baixo carbono, falta de conhecimento sobre as linhas do programa pelos bancos e produtores, custo real dos empréstimos acima da taxa de juros devido à necessidade de projeto técnico, falta de literatura 
consolidada em atividades de integração, dificuldades com a documentação necessária como o Cadastro Ambiental Rural (CAR), desafio na estimação de risco ao conceder o empréstimo, entre outros fatores.

De acordo com o Observatório ABC (2015) em estudo de caso no município de Paragominas/PA, problemas com a regularização fundiária, a ausência do CAR, a necessidade de adequação ou recuperação de Áreas de Preservação Permanente (APP) e áreas de Reserva Legal (RL) e assistência técnica limitada são grandes deficiências da região para as contratações do ABC. As sugestões para solucionar os problemas encontrados foram: associar a concessão de crédito à assistência técnica, realizar ações para regularização fundiária e ambiental, capacitar técnicos para elaboração de projetos para o ABC e permissão da recontratação do Programa $\mathrm{ABC}$ para recursos voltados a manutenção das pastagens já constituídas pelo Programa.

Em novo estudo de caso, o (Observatório ABC, 2017c) verificou as características do município de Alta Floresta/MT, identificando fatores de impacto de ordem estrutural, local e conjuntural. Entre os fatores de ordem estrutural, estão a falta de comunicação entre o Programa $\mathrm{ABC}$ e os produtores rurais, a baixa qualificação dos projetistas quanto às linhas do $\mathrm{ABC}$, a falta de competitividade das taxas de juros do $\mathrm{ABC}$ frente às demais linhas do Crédito Rural, divergência das condições de pagamento e valores de crédito anunciadas pelo Programa e oferecidas pelos bancos, excessiva burocracia, lentidão na avaliação dos projetos, falta de avaliação técnica específica às características produtivas locais e dificuldades com a regularização de licenças ambientais.

Segundo Assad (2015) o Plano e Programa ABC tem condições de cumprir e até mesmo superar a meta de mitigação de GEE, com reduções entre 133 e 166 milhões de toneladas de $\mathrm{CO}_{2}$ equivalente. No entanto, a adesão ao Programa tem se mostrado aquém do necessário para cumprir os objetivos. Estima-se que mesmo um aumento de $80 \%$ no volume de contratos em comparação ao realizado até a safra 2012/13, não seria suficiente para cumprir o esperado para o Programa. O autor identificou carências na realização do Programa em relação à divulgação e disseminação das técnicas, principalmente quanto à assistência técnica, afetando em grande escala as regiões Norte e Nordeste. O desequilíbrio da distribuição regional dos contratos apontadas anteriormente também é relacionado pelo autor. A implementação de ferramentas de monitoramento das mitigações, reajustes na taxa de juros para tornar o Programa mais atrativo frente a outras opções do Crédito Rural e reajuste entre as participações dos agentes financeiros, são ações indicadas como necessárias. 
Identificadas as deficiências do Plano e Programa ABC, o Observatório ABC (2015b) realizou uma proposta de revisão com várias ações estruturais, de divulgação e capacitação, alterações institucionais e de governança, implantação de sistema de monitoração, incremento da transparência e geração maior de produção técnico cientifica baseando os sistemas agrícolas propostos. Destaca-se dentre as propostas a indicação da necessidade de priorizar os recursos de acordo com o potencial de mitigação de GEE.

Observando os resultados encontrados na literatura disponível sobre a execução e distribuição dos recursos encontram-se deficiências que não foram exploradas. A utilização da aptidão agrícola (APT) ${ }^{9}$ como proxy do beneficio potencial dos investimentos do Plano e Programa $\mathrm{ABC}$ proporciona avaliação única a respeito do cumprimento dos objetivos traçados. Na literatura a relação dos empréstimos do ABC com os aspectos ambientais ou econômicos frequentemente é questionada. Por meio da Correlação de Spearman poderão ser obtidos os coeficientes de associação dos empréstimos do $\mathrm{ABC}$ e variáveis de desempenho da agropecuária, da economia e de indicadores ambientais, de maneira a proporcionar uma análise mais específica sobre o tema.

9 Mais detalhes sobre a variável são apresentados nas seções 3.1, Anexo I e Anexo II. 


\section{METODOLOGIA}

Nesta seção detalha-se a construção da base de dados referente aos empréstimos do Programa ABC. São apresentados os critérios das variáveis de desempenho da agropecuária, economia, aptidão agrícola e perfil agropecuário. Por fim, são demonstrados os métodos para o calculo da correlação de Spearman.

\subsection{Base de Dados}

Os dados utilizados neste trabalho sobre o Programa $\mathrm{ABC}$ foram cedidos pelo Ministério da Agricultura, Pecuária e Abastecimento (MAPA) e são provenientes do Sistema de Operações do Crédito Rural e Proagro (SICOR). Os dados abrangem de janeiro de 2013 a outubro de 2016 e contém informações sobre os subprogramas citados nas seções 2.2.1 e 2.2.2, sobre as modalidades (Aquisição de Animais (AA), Aquisição de Animais de Serviço (AAS), Aquisição de Veículos (AV), Formação de Culturas Perenes (FCP), Máquinas e Equipamentos (MEQ), Melhoramento das Explorações (MEX) e Outras Modalidades (OM)) e das atividades (Agricultura ou Pecuária). Os dados dos empréstimos realizados em datas anteriores a criação do SICOR em 2013 - em vista da implementação do Programa ABC em 2010 - não foram possíveis de serem agregados de forma padronizada.

Na construção dos resultados houve a inclusão do subprograma de FBN em grupo que abrange os subprogramas de menor expressão (OUT), devido à existência de uma única observação ${ }^{10}$ deste subprograma. Os estados que possuem baixa participação percentual em relação ao total de empréstimos do Programa $\mathrm{ABC}$ foram agrupados nos totais de suas respectivas regiões (Nordeste, Norte, Centro-Oeste, Sudeste e Sul).

O tratamento dos dados adquiridos resultou em duas bases de dados, a "Base 1" está agregada de maneira a proporcionar informações sobre os subprogramas, quantidade de contratos e área. A "Base 2" possui desagregação quanto as atividades produtivas, modalidades de empréstimos e número de observações.

A "Base 1" é ligeiramente maior devido a existência de alguns contratos nos quais não foi possível realizar a desagregação das atividades produtivas e modalidades de empréstimos. A "Base 2" não possui número de contratos (substituídos pelas observações) pois, a

10 Contrato registrado em Paranaíba/MS de Aptidão Agrícola "A", no valor de R\$ 2 milhões, sem atribuição de área. 
possibilidade de existência de múltiplas atividades e/ou modalidades de empréstimos referentes à um mesmo "contrato" do Programa ABC resulta na diferenciação das "observações" do banco de dados de "quantidade de contratos". Por construção da base original de dados, a área também não pode ser aferida através da "Base 2".

Durante a construção das bases de dados observaram-se características peculiares quanto às áreas de implementação. Aproximadamente 2628 contratos não possuem a área especificada, mas respondem por quase $\mathrm{R} \$ 1,23$ bilhão dos empréstimos concedidos. Expandindo o intervalo para contratos que apresentam área de implementação de até 2 hectares, encontram-se 2896 contratos que representam $\mathrm{R} \$ 1,4$ bilhão em crédito.

Os estados de RS e GO abrangeram respectivamente 0,25 milhão e 1 milhão de hectares de iLPF, somando cerca de 93,5\% da área total deste subprograma, enquanto representam em conjunto cerca de $19 \%$ do crédito. Em RS, um contrato destinado a município de APT "A" abrangeu cerca de 230 mil hectares. Em GO, um contrato realizado em município de APT "B" representou 1 milhão de hectares. Isto indica que existe falha no abastecimento de informações na base de dados.

No estado do PR, um contrato de FLP destinado a município de APT “CD” recebeu R\$ 1,4 milhão para uma área de 290 mil hectares. O contrato em questão representa cerca de $0,1 \%$ do crédito total concedido para FLP, no entanto, corresponde a aproximadamente $47 \%$ da área.

Estas atribuições de área limitam a percepção de resultados que podem ser auferidos através desta variável. Deste modo, a comparação das metas de área anunciadas pelo Plano ABC e o realizado durante o período de análise, não será realizada. No entanto, algumas avaliações sobre valores médios por hectare e distribuição de área entre as Unidades da Federação ainda são apresentadas.

A Tabela 1 contém a descrição do crédito concedido e área por subprograma do ABC de acordo com as bases construídas e mencionadas nos parágrafos anteriores. Algumas observações foram excluídas de ambas as bases, em sua maioria pela falta de caracterização da APT. As observações excluídas representam aproximadamente 1,02\% do crédito concedido e $0,48 \%$ da área de abrangência da "Base 1 " e por volta de $1,08 \%$ e $0,52 \%$ da "Base 2", respectivamente. 
Tabela 1. Descrição das bases de dados utilizadas, crédito em reais e área em hectares.

\begin{tabular}{c|c|c|c|c|c|c|c|c|c}
\hline \multirow{2}{*}{ Subprog. } & \multicolumn{3}{|c}{ Excluídos } & \multicolumn{3}{c|}{ Base 2 } & \multicolumn{3}{c|}{ Base 1 } \\
\cline { 2 - 11 } & Crédito & Área & Cont. & Crédito & Área & Cont. & Crédito & Área & Cont. \\
\hline RPD & 55.722 .917 & 14.880 & 94 & 4.792 .993 .399 & 1.739 .111 & - & 5.094 .867 .375 & 1.832 .851 & 11.574 \\
\hline SPD & 9.820 .013 & 7.263 & 19 & 2.429 .195 .436 & 1.679 .653 & - & 2.526 .711 .310 & 1.746 .007 & 4.954 \\
\hline iLPF & 12.324 .229 & 1.788 & 10 & 659.524 .425 & 1.391 .045 & - & 735.451 .370 & 1.409 .695 & 1.338 \\
\hline FP & 14.496 .534 & 3.049 & 25 & 1.234 .094 .209 & 309.371 & - & 1.306 .335 .448 & 612.373 & 2.595 \\
\hline ARA & 504.698 & 75 & 2 & 9.429 .088 & 5.916 & - & 9.429 .088 & 5.916 & 19 \\
\hline TDA & 1.775 .151 & 0 & 2 & 28.899 .699 & 320 & - & 28.899 .699 & 320 & 51 \\
\hline OUT & 2.280 .595 & 30 & 5 & 120.625 .444 & 35.897 & - & 120.625 .444 & 35.897 & 88 \\
\hline SS & 4.663 .467 & 0 & 1 & 0 & 0 & - & 0 & 0 & 0 \\
\hline TOTAL & 101.587 .604 & 27.085 & 158 & 9.274 .761 .700 & 5.161 .312 & - & 9.822 .319 .734 & 5.643 .058 & 20.619 \\
\hline FOnte:
\end{tabular}

Fonte: resultados da pesquisa.

Informações com discriminação municipal de área de pastagens, área de agricultura, área de pastagens degradadas, rebanho animal, tamanho das propriedades rurais, entre outros dados do meio rural foram obtidos através do Censo Agropecuário de 2006, realizado pelo Instituto Brasileiro de Geografia e Estatística (2006). Complementarmente dados da Produção Agrícola Municipal (PAM), Pesquisa Pecuária Municipal (PPM) e Produção da Extração Vegetal e da Silvicultura (PEVS) também foram adquiridos através do Instituto Brasileiro de Geografia e Estatística (2017a; b; c).

A classificação apresentada na Tabela 2 sobre o tamanho predominante das propriedades rurais e principal produto agrícola por município (perfil agropecuário) foi realizada conforme a tabela "4118 - Número de estabelecimentos agropecuários com produção no ano e Valor da produção no ano, por tipo de produção e classificações de médio produtor", resultado do Censo Agropecuário de 2006 (INSTITUTO BRASILEIRO DE GEOGRAFIA E ESTATÍSTICA, 2006). 
Tabela 2. Classificação do Perfil Agropecuário.

\begin{tabular}{c|c}
\hline Nomenclatura do Censo Agropecuário de 2006 & Classificação Utilizada \\
\hline Familiar, pronafiano, não classificado como médio produtor & Familiar \\
\hline Familiar, não pronafiano, classificado como médio produtor & \multirow{2}{*}{ Médio } \\
\hline Não familiar, módulo fiscal, classificado como médio produtor & Grande \\
\hline Outros não classificados & \multirow{2}{*}{ Animal } \\
\hline Animal - de grande porte & \\
\hline Animal - de médio porte & Lavouras permanentes \\
\hline Animal - aves & Lavouras temporárias \\
\hline Aegetal - lavouras permanentes & \multirow{2}{*}{ Floricultura e horticultura } \\
\hline Vegetal - lavouras temporárias & Silvicultura e extração \\
\cline { 1 - 1 } Vegetal - floricultura & vegetal \\
\hline Vegetal - horticultura & Agroindústria \\
\hline Vegetal - silvicultura &
\end{tabular}

Fonte: elaboração própria, dados do Instituto Brasileiro de Geografia e Estatística (2006).

A variável de $\mathrm{APT}^{11}$ (Figura 2) disponível a nível municipal representa uma análise inédita do potencial agrícola dos municípios em que estão sendo aplicados recursos do Programa ABC. Esta variável é utilizada como proxy do potencial de mitigação de emissões de GEE dos empréstimos. Quando os recursos são aplicados em regiões de predominância da alta APT, espera-se baixo retorno em termos ambientais, logo, os recursos destinados para regiões de baixa APT devem gerar maiores benefícios ambientais. A APT é classificada como:

“A Aptidão Agrícola é uma variável territorial complexa que integra aspectos ligados à fertilidade do solo, vocação climática e relevo. Esta deve refletir as condições existentes para o cultivo sem irrigação de culturas anuais. A informação de Aptidão foi calculada em uma resolução espacial de $90 \times 90$ metros seguindo o máximo detalhamento de seu componente relevo. A Aptidão é calculada inicialmente como variável quantitativa contínua, que é posteriormente subdivida em categorias: Alta, Média, Baixa e Muito Baixa." (SPAROVEK, 2015).

11 O procedimento de construção da variável encontra-se delimitado no Anexo I e II. 


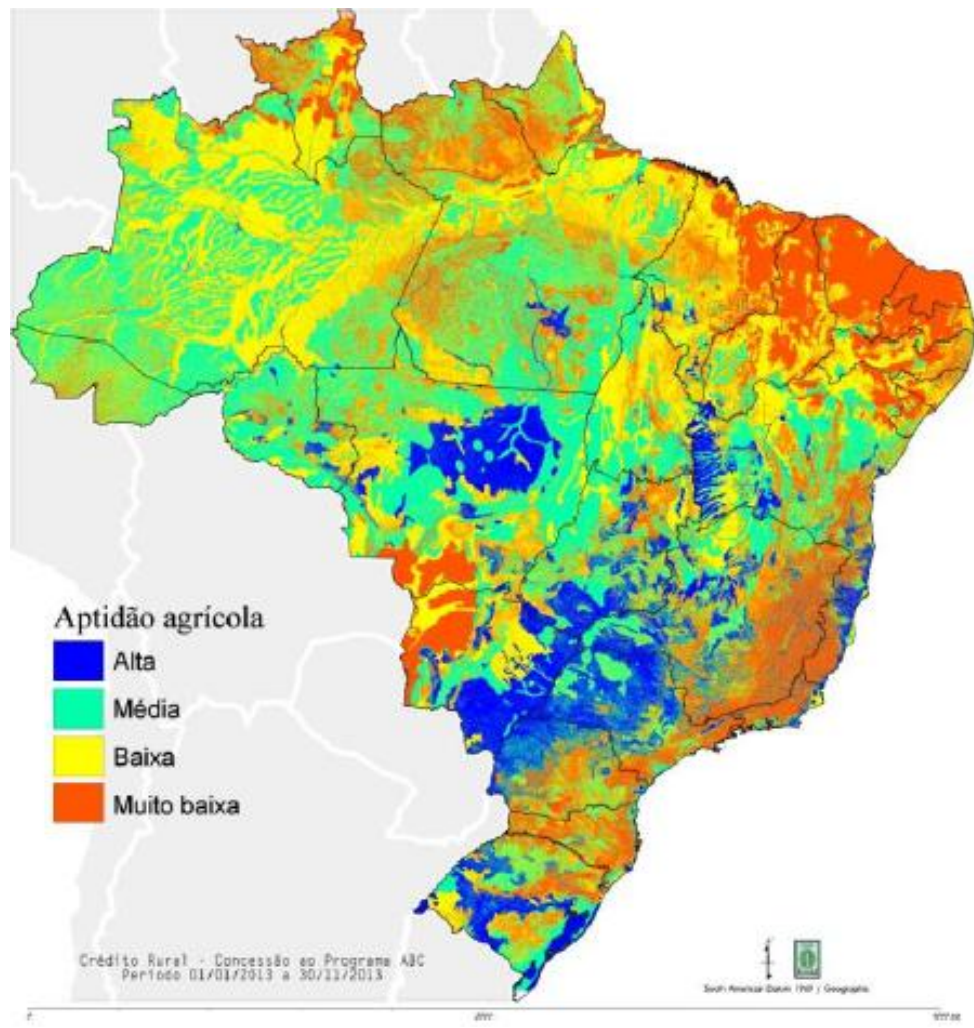

Figura 2. Classes de APT para o território brasileiro.

Fonte: SPAROVEK (2015).

A Tabela 3 contém as legendas utilizadas para a caracterização de variáveis na seção de Resultados e Discussões. 
Tabela 3. Legenda de Siglas para os Resultados.

\begin{tabular}{|c|c|}
\hline ARA & Adequação e/ou Regulação Ambiental \\
\hline FBN & Fixação Biológica de Nitrogênio \\
\hline FLP & Florestas Plantadas \\
\hline iLPF & Integração Lavoura-Pecuária-Floresta \\
\hline OUT & Outros, FBN e em sua maioria Financiamentos com Recursos dos Fundos Constitucionais \\
\hline OUT* $^{*}$ & ARA, TDA, FBN, OUT e Sem Subprograma \\
\hline RPD & Recuperação de Pastagens Degradadas \\
\hline SPD & Sistema de Plantio Direto \\
\hline TDA & Tratamento de Dejetos \\
\hline SS & Sem Subprograma \\
\hline FAG & Familiar Agroindústria \\
\hline FAN & Familiar Animal \\
\hline FHF & Familiar Horticultura e Floricultura \\
\hline FLP & Familiar Lavouras Permanentes \\
\hline FLT & Familiar Lavouras Temporárias \\
\hline FSE & Familiar Silvicultura e Extração Vegetal \\
\hline GAN & Grande Animal \\
\hline GHF & Grande Horticultura e Floricultura \\
\hline GLP & Grande Lavouras Permanentes \\
\hline GLT & Grande Lavouras Temporárias \\
\hline GSE & Grande Silvicultura e Extração Vegetal \\
\hline MAN & Médio Animal \\
\hline MHF & Médio Horticultura e Floricultura \\
\hline MLP & Médio Lavouras Permanentes \\
\hline MLT & Médio Lavouras Temporárias \\
\hline MSE & Médio Silvicultura e Extração Vegetal \\
\hline AA & Aquisição de Animais \\
\hline AAS & Aquisição de Animais de Serviço \\
\hline $\mathrm{AV}$ & Aquisição de Veículos \\
\hline FCP & Formação de Culturas Perenes \\
\hline MEQ & Máquinas e Equipamentos \\
\hline MEX & Melhoramento das Explorações \\
\hline $\mathrm{OM}$ & Outras Modalidades \\
\hline
\end{tabular}

Fonte: resultados da pesquisa.

\subsection{Correlação de Spearman ${ }^{12}$}

A correlação é um indicador utilizado para verificar o relacionamento entre duas ou mais variáveis. Este indicador varia de $-1 \leq r \leq 1$ onde os extremos indicam uma associação perfeita, inversa ou diretamente proporcional e uma correlação igual à zero indica

12 Toda esta seção foi baseada no texto de Chen e Popovich (2002). 
ausência de relação entre as variáveis. A correlação negativa expressa que as variáveis são direcionadas em sentidos opostos, ou seja, o crescimento de uma está correlacionado com o decréscimo de outra - vice e versa -, por sua vez a correlação positiva indica que as variáveis apresentarão movimentos no mesmo sentido, assim o crescimento de uma variável está associado ao crescimento da outra - vice e versa.

O coeficiente de correlação mais conhecido é o de Pearson, que mensura a força de associação linear entre as variáveis. Se a relação entre as variáveis for exponencial, quadrática, ou demais formas não lineares, o indicador de Pearson não apresentará uma medida correta da correlação. Neste sentido, para avaliar a correlação dos empréstimos do Programa ABC com variáveis de rebanho animal, áreas degradadas e produção agrícola o coeficiente de correlação de Spearman será utilizado.

A correlação de Spearman é similar à correlação de Pearson, no entanto utiliza os postos ou rank das variáveis ao invés de seus valores. Ao realizar a correlação dos postos para as variáveis selecionadas neste trabalho, a ferramenta de análise trará um resultado mais claro, onde poderemos assumir algumas relações entre as variáveis e testa-las empiricamente. Como exemplo: um município com maior rank em áreas degradadas deveria obter também um maior posto no subprograma de Recuperação de Pastagens Degradadas.

Vale ressaltar que assim como a correlação de Pearson, a correlação de Spearman não representa causalidade, ou seja, apenas expressa uma associação entre o comportamento das variáveis, digamos "x" e " $y$ " e, não se "x" causa " $y$ " ou “ $y$ " causa "x". A correlação de Spearman é útil para auferir a presença de relações extremamente importantes aos objetivos do Plano e Programa ABC entre os empréstimos realizados e variáveis ambientais.

A formulação da correlação de Pearson entre duas variáveis, digamos " $x$ " e " $y$ " ocorre primeiramente no estabelecimento dos ranks das variáveis, onde para cada uma delas, suas observações de maior valor deverão obter o rank "1", consecutivamente a segunda maior observação o rank "2" e assim por diante. Em caso de empates no valor das variáveis de um mesmo grupo, no caso " $\mathrm{x}$ ” ou " $\mathrm{y}$ ”, utiliza-se o dobro do posto em questão, adicionado uma unidade e então divide-se pela metade, onde as observações de mesmo valor obterão o mesmo posto, resultado desta fórmula (Se k=posto, $\frac{2 k+1}{2}$ ). Por fim o coeficiente de correlação de Spearman é calculado por:

$$
r_{s}=1-\frac{6 * \sum_{i=1}^{n} d_{i}^{2}}{n^{3}-n}
$$


$r_{s}$ : Coeficiente de correlação de Spearman

$d_{i}: r_{x i}-r_{y i}$

n: número de variáveis

Para a realização da correlação de Spearman foram selecionadas variáveis prioritariamente da agropecuária. As variáveis de rebanho animal (IBGE, 2017c), valor das lavouras temporárias, valor das lavouras permanentes e valor da silvicultura e extração vegetal (INSTITUTO BRASILEIRO DE GEOGRAFIA E ESTATÍSTICA, 2017a; b; c)foram construídas a partir da média ${ }^{13}$ dos valores obtidos nos anos de 2013, 2014 e 2015, anos os quais estão disponíveis as informações e também estão contemplados no período dos dados dos financiamentos do Programa ABC. Para verificar a correlação dos empréstimos do ABC e o desenvolvimento econômico, a variável de PIB municipal foi selecionada, incluindo os anos de 2013 e 2014 também devido a serem os últimos dados disponíveis a partir do primeiro ano da base de dados sobre o Programa. Por fim, a variável de pastagens degradadas foi adquirida no último Censo Agropecuário (INSTITUTO BRASILEIRO DE GEOGRAFIA E ESTATÍSTICA, 2006) disponível.

13 Em termos da realização da Correlação de Spearman, se utilizada apenas a soma dos valores brutos o resultado seria o mesmo, já que são utilizados os "ranks" dos municípios em relação às variáveis. 


\section{RESULTADOS E DISCUSSÃO}

Nesta seção serão apresentados os resultados encontrados e a discussão do problema de pesquisa. Primeiramente trata-se da análise do crédito concedido, área e quantidade de contratos do Programa ABC através da "Base 1". A segunda subseção aborda as características das atividades (agrícola e pecuária), com informações da "Base 2". Em seguida, retoma-se a "Base 1" para realização da Correlação de Spearman e discussão sobre deficiências encontradas na execução e alocação de recursos do ABC. Por fim, são apresentadas algumas especificidades sobre o perfil agropecuário e modalidades.

\subsection{Execução e Distribuição de Recursos do Plano e Programa ABC: Aptidão Agrícola e Subprogramas}

Do inicio do Programa ABC em 2010 até junho de 2016 cerca de R\$ 13,8 bilhões foram contratados (BARROS, 2017). Através da Tabela 4 referente ao período de 2013-2016, pode-se notar que a base de dados utilizada representa aproximadamente $\mathrm{R} \$ 9,8$ bilhões em crédito com a classificação adequada dos subprogramas, ou seja, diferença de aproximadamente $\mathrm{R} \$ 4$ bilhões em período de tempo 3 anos inferior ${ }^{14}$. Ainda que exista esta divergência de período e crédito concedido, as informações utilizadas presam a fidelidade da agregação dos subprogramas, bem como a disponibilidade de mais de 20 mil contratos e o volume de crédito listado, são expressivos e suficientes para a caracterização desejada neste trabalho.

Verifica-se a partir da Tabela 4 o crédito concedido, área abrangida e quantidade de contratos por subprogramas e regiões brasileiras. Observa-se que os subprogramas de RPD, SPD, FLP e iLPF somam cerca de 98,4\% do crédito concedido, 99,3\% da área e 99,2\% dos contratos. Existe predominância da atividade de Recuperação de Pastagens Degradadas (RPD) em relação às demais linhas do Programa ABC. Cabe destacar que as florestas plantadas (FLP) e integração (iLPF) são programas praticamente exclusivos do Centro-Sul.

14 Existe a dificuldade de comparar diretamente os valores apresentados neste texto ao de outros trabalhos, pois estes utilizam a noção de ano safra, que não é contemplada neste trabalho. 
Tabela 4. Crédito concedido (em milhões de reais), área (em hectares) e contratos por subprogramas e regiões.

\begin{tabular}{|c|c|c|c|c|c|c|c|c|c|c|c|c|c|c|c|c|c|c|c|c|c|}
\hline \multirow{2}{*}{ Região } & \multicolumn{7}{|c|}{ Crédito Concedido } & \multicolumn{7}{|c|}{ Área } & \multicolumn{7}{|c|}{ Contratos } \\
\hline & RPD & SPD & iLPF & FLP & ARA & TDA & OUT & RPD & SPD & iLPF & FLP & ARA & \begin{tabular}{|l|} 
TDA \\
\end{tabular} & OUT & RPD & SPD & iLPF & FLP & ARA & \begin{tabular}{|l|} 
TDA \\
\end{tabular} & OUT \\
\hline Norte & 809,51 & 143,71 & 27,69 & 55,41 & 0,50 & 1,13 & 90,67 & 314.474 & 115.044 & 17.101 & 19.004 & 169 & 0 & 13.925 & 1.543 & 248 & 45 & 75 & 1 & 1 & 54 \\
\hline $\mathrm{AC}$ & 70,85 & 0,00 & 1,64 & 0,00 & 0,00 & 0,00 & 2,85 & 14.725 & 0 & 432 & 0 & 0 & 0 & 849 & 153 & 0 & 3 & 0 & 0 & 0 & 10 \\
\hline $\mathrm{AP}$ & 2,68 & 3,14 & 0,00 & 0,00 & 0,00 & 0,00 & 0,00 & 3.140 & 2.420 & 0 & 0 & 0 & 0 & 0 & 4 & 9 & 0 & 0 & 0 & 0 & 0 \\
\hline $\mathrm{PA}$ & 224,30 & 8,85 & 4,55 & 2,49 & 0,00 & 0,00 & 52,56 & 79.198 & 4.558 & 1.199 & 695 & 0 & 0 & 7.308 & 303 & 14 & 6 & 4 & 0 & 0 & 14 \\
\hline RO & 123,29 & 5,32 & 0,80 & 7,20 & 0,50 & 0,00 & 11,83 & 68.656 & 72 & 248 & 970 & 169 & 0 & 3.700 & 240 & 6 & 1 & 5 & 1 & 0 & 10 \\
\hline $\mathrm{RR}$ & 10,14 & 6,43 & 4,59 & 0,00 & 0,00 & 0,00 & 0,00 & 2.284 & 14.680 & 2.435 & 0 & 0 & 0 & 0 & 14 & 6 & 4 & 0 & 0 & 0 & 0 \\
\hline TO & 376,47 & 119,97 & 16,11 & 45,72 & 0,00 & 1,13 & 23,42 & 145.923 & 93.314 & 12.787 & 17.339 & 0 & 0 & 2.068 & 826 & 213 & 31 & 66 & 0 & 1 & 20 \\
\hline Nordeste & 320,00 & 519,99 & 42,15 & 47,16 & 0,00 & 0,00 & 2,34 & 99.802 & 417.148 & 7.827 & 13.877 & 0 & 0 & 52 & 723 & 667 & 61 & 86 & 0 & 0 & 2 \\
\hline BA & 157,38 & 363,91 & 34,81 & 39,98 & 0,00 & 0,00 & 2,34 & 56.781 & 277.899 & 6.607 & 8.162 & 0 & 0 & 52 & 307 & 454 & 48 & 70 & 0 & 0 & 2 \\
\hline MA & 142,32 & 67,66 & 5,39 & 5,80 & 0,00 & 0,00 & 0,00 & 38.646 & 63.697 & 996 & 4.674 & 0 & 0 & 0 & 363 & 108 & 8 & 13 & 0 & 0 & 0 \\
\hline PE & 7,52 & 0,00 & 1,43 & 0,05 & 0,00 & 0,00 & 0,00 & 1.776 & 0 & 224 & 0 & 0 & 0 & 0 & 31 & 0 & 4 & 1 & 0 & 0 & 0 \\
\hline PI & 9,49 & 88,43 & 0,52 & 1,33 & 0,00 & 0,00 & 0,00 & 2.155 & 75.552 & 0 & 1.041 & 0 & 0 & 0 & 13 & 105 & 1 & 2 & 0 & 0 & 0 \\
\hline Centro-Oeste & $2.038,87$ & 854,90 & 233,56 & 429,80 & 0,65 & 1,96 & 27,43 & 845.770 & 612.255 & 1.067 .855 & 102.322 & 153 & 0 & 21.890 & 3.813 & 1.244 & 213 & 306 & 3 & 3 & 31 \\
\hline $\mathrm{GO}$ & 918,47 & 378,33 & 96,88 & 86,82 & 0,41 & 0,00 & 2,38 & 412.067 & 225.189 & 1.015 .745 & 17.500 & 132 & 0 & 1.786 & 2.108 & 620 & 124 & 137 & 2 & 0 & 11 \\
\hline MT & 568,92 & 316,79 & 64,61 & 43,21 & 0,24 & 0,20 & 12,36 & 215.407 & 293.369 & 29.831 & 16.561 & 21 & 0 & 17.043 & 728 & 376 & 41 & 52 & 1 & 1 & 7 \\
\hline MS & 551,30 & 158,86 & 71,97 & 299,77 & 0,00 & 0,56 & 12,69 & 218.297 & 92.636 & 22.279 & 68.262 & 0 & 0 & 3.061 & 976 & 245 & 47 & 117 & 0 & 1 & 13 \\
\hline Sudeste & $1.450,75$ & 629,28 & 352,77 & 636,48 & 0,46 & 11,27 & 0,18 & 385.870 & 191.259 & 53.507 & 156.299 & 5.096 & 320 & 30 & 4.234 & 1.380 & 828 & 1.692 & 5 & 22 & 1 \\
\hline ES & 56,93 & 5,41 & 36,04 & 12,17 & 0,00 & 0,23 & 0,18 & 15.600 & 1.244 & 3.575 & 1.927 & 0 & 0 & 30 & 123 & 11 & 98 & 49 & 0 & 1 & 1 \\
\hline MG & 835,04 & 288,66 & 191,33 & 340,25 & 0,22 & 9,56 & 0,00 & 240.794 & 127.252 & 34.317 & 81.384 & 5.052 & 291 & 0 & 2.316 & 469 & 366 & 683 & 3 & 16 & 0 \\
\hline $\mathrm{RJ}$ & 22,44 & 0,02 & 1,10 & 4,75 & 0,00 & 0,38 & 0,00 & 3.319 & 0 & 120 & 304 & 0 & 29 & 0 & 73 & 1 & 2 & 10 & 0 & 1 & 0 \\
\hline SP & 536,34 & 335,19 & 124,31 & 279,32 & 0,24 & 1,10 & 0,00 & 126.157 & 62.764 & 15.496 & 72.685 & 44 & 0 & 0 & 1.722 & 899 & 362 & 950 & 2 & 4 & 0 \\
\hline Sul & 475,75 & 378,84 & 79,28 & 137,48 & 7,82 & 14,54 & 0,00 & 186.935 & 410.300 & 263.406 & 320.871 & 498 & 0 & 0 & 1.261 & 1.415 & 191 & 436 & 10 & 25 & 0 \\
\hline PR & 211,69 & 99,74 & 26,75 & 103,57 & 2,82 & 6,79 & 0,00 & 52.848 & 91.343 & 12.103 & 312.439 & 498 & 0 & 0 & 561 & 492 & 66 & 281 & 6 & 13 & 0 \\
\hline RS & 220,63 & 243,78 & 42,06 & 18,63 & 5,00 & 0,65 & 0,00 & 110.486 & 300.934 & 250.185 & 5.427 & 0 & 0 & 0 & 511 & 833 & 91 & 71 & 4 & 2 & 0 \\
\hline $\mathrm{SC}$ & 43,43 & 35,32 & 10,47 & 15,28 & 0,00 & 7,10 & 0,00 & 23.601 & 18.023 & 1.118 & 3.005 & 0 & 0 & 0 & 189 & 90 & 34 & 84 & 0 & 10 & 0 \\
\hline Brasil & $5.094,87$ & $2.526,71$ & 735,45 & $1.306,34$ & 9,43 & 28,90 & 120,63 & 1.832 .851 & 1.746 .007 & 1.409 .695 & 612.373 & 5.916 & 320 & 35.897 & 11.574 & 4.954 & 1.338 & 2.595 & 19 & 51 & 88 \\
\hline
\end{tabular}

Fonte: resultados da pesquisa. 
Através das informações dos empréstimos concedidos verifica-se que os Programas ABC Orgânico, ABC Ambiental (ARA), ABC Tratamento de Dejetos (TDA), ABC Dendê, ABC Fixação (FBN) e ABC Bioma Amazônia possuem ínfimo volume de contratos. Estes subprogramas dificilmente atingirão as metas do Plano ABC. A baixa aderência a estas linhas indica que devem existir deficiências na concepção das técnicas propostas e/ou mecanismo de empréstimo. O ABC Orgânico, ABC Dendê e ABC Bioma Amazônia apresentam desafios na análise de suas deficiências devido a não contemplação dos mesmos no Plano ABC.

De acordo com Hungria, Mendes e Mercante (2013) a aplicação de fixação biológica de nitrogênio é lucrativa e a implementação desta tecnologia apenas nas culturas de feijão e soja seria suficiente para cumprir as metas do Plano ABC para este subprograma. No entanto, observou-se apenas um contrato deste subprograma. Deficiências na concepção da técnica, falta de conhecimento dos produtores, baixa disponibilidade dos insumos ou entraves na linha de financiamento são algumas das hipóteses para este fenômeno. Os autores indicam a possibilidade de baixo interesse pelos produtores em adquirir os contratos especificamente de FBN, pois ao adquirir contratos como SPD e iLPF podem utilizar os recursos para implementar a FBN, sem a necessidade de tomar diretamente o recurso de FBN. Utilizando dados expostos pela Embrapa (2013) o custo de inoculação de FBN na cultura de soja era de aproximadamente $\mathrm{R} \$ 8,00$ por hectare, valor suficientemente baixo para corroborar com a hipótese de Hungria, Mendes e Mercante (2013) da inexistência de necessidade de contratação de linha específica de crédito para implementar a FBN.

Quanto ao subprograma de TDA, entraves na aquisição de material especifico para a compostagem do material orgânico e armazenamento do combustível gerado, baixa capacidade técnica do produtor para implementação do sistema e falta de destino ou de compradores para o combustível gerado, são algumas das possibilidades para a pequena representatividade deste subprograma no total de empréstimos do ABC.

A proposta para adequação e/ou regularização ambiental (ARA), visando principalmente recuperar Áreas de Preservação Permanente (APPs) e Reserva Legal (RL) pode não ser atrativa para os produtores rurais. A adequação de APPs e RL não geram impactos econômicos positivos, normalmente constituem apenas em dispêndio dos produtores para regularizar o imóvel rural de acordo com a Lei. 
Tabela 5. Valor médio dos contratos e por hectare por subprogramas e regiões. Em reais.

\begin{tabular}{|c|c|c|c|c|c|c|c|c|c|c|c|c|c|c|}
\hline \multirow[t]{2}{*}{ Região } & \multicolumn{7}{|c|}{ Valor Médio dos Contratos } & \multicolumn{7}{|c|}{ Valor por Hectare } \\
\hline & RPD & SPD & iLPF & FLP & ARA & TDA & OUT & RPD & SPD & iLPF & FLP & ARA & TDA & OUT \\
\hline $\mathrm{AC}$ & 463.044 & 0 & 545.099 & 0 & 0 & 0 & 285.158 & 4.811 & 0 & 3.785 & 0 & 0 & 0 & 3.359 \\
\hline PA & 740.252 & 632.329 & 758.591 & 622.163 & 0 & 0 & 3.754 .220 & 2.832 & 1.942 & 3.798 & 3.583 & 0 & 0 & 7.192 \\
\hline RO & 513.705 & 886.544 & 799.907 & 1.439 .929 & 495.773 & 0 & 1.183 .449 & 1.796 & 73.868 & 3.225 & 7.419 & 2.929 & 0 & 3.199 \\
\hline RR & 724.015 & 1.071 .089 & 1.147 .144 & 0 & 0 & 0 & 0 & 4.438 & 438 & 1.884 & 0 & 0 & 0 & 0 \\
\hline TO & 455.773 & 563.240 & 519.714 & 692.755 & 0 & 1.132 .219 & 1.171 .228 & 2.580 & 1.286 & 1.260 & 2.637 & 0 & 0 & 11.329 \\
\hline MA & 392.057 & 626.473 & 674.292 & 446.074 & 0 & 0 & 0 & 3.683 & 1.062 & 5.414 & 1.241 & 0 & 0 & 0 \\
\hline $\mathrm{PE}$ & 242.490 & 0 & 357.000 & 54.769 & 0 & 0 & 0 & 4.233 & 0 & 6.375 & 0 & 0 & 0 & 0 \\
\hline PI & 730.210 & 842.169 & 520.018 & 665.948 & 0 & 0 & 0 & 4.405 & 1.170 & 0 & 1.279 & 0 & 0 & 0 \\
\hline Centro-Oeste & 534.714 & 687.217 & 1.096 .540 & 1.404 .565 & 217.025 & 654.545 & 884.778 & 2.411 & 1.396 & 219 & 4.200 & 4.263 & 0 & 1.253 \\
\hline GO & 435.706 & 610.203 & 781.302 & 633.689 & 205.972 & 0 & 216.653 & 2.229 & 1.680 & 95 & 4.961 & 3.122 & 0 & 1.334 \\
\hline MT & 781.489 & 842.514 & 1.575 .865 & 830.898 & 239.130 & 201.227 & 1.765 .684 & 2.641 & 1.080 & 2.166 & 2.609 & 11.524 & 0 & 725 \\
\hline $\mathrm{RJ}$ & 307.453 & 15.200 & 548.072 & 474.647 & 0 & 381.866 & 0 & 6.762 & 0 & 9.135 & 15.639 & 0 & 13.168 & 0 \\
\hline SP & 311.461 & 372.848 & 343.387 & 294.020 & 121.672 & 274.777 & 0 & 4.251 & 5.341 & 8.022 & 3.843 & 5.549 & 0 & 0 \\
\hline Sul & 377.276 & 267.729 & 415.075 & 315.323 & 782.019 & 581.536 & 0 & 2.545 & 923 & 301 & 428 & 15.708 & 0 & 0 \\
\hline PR & 377.341 & 202.727 & 405.260 & 368.573 & 470.031 & 522.308 & 0 & 4.006 & 1.092 & 2.210 & 331 & 5.665 & 0 & 0 \\
\hline RS & 431.759 & 292.648 & 462.230 & 262.444 & 1.250 .000 & 324.648 & 0 & 1.997 & 810 & 168 & 3.433 & 125.000 .000 & 0 & 0 \\
\hline SC & 229.778 & 392.429 & 307.919 & 181.885 & 0 & 709.911 & 0 & 1.840 & 1.960 & 9.363 & 5.084 & 0 & 0 & 0 \\
\hline Brasil & 440.199 & 510.035 & 549.665 & 503.405 & 496.268 & 566.661 & 1.370 .744 & 2.780 & 1.447 & 522 & 2.133 & 1.594 & 90.312 & 3.360 \\
\hline
\end{tabular}

Fonte: resultados da pesquisa. 
Além da concentração encontrada nas linhas de financiamento do Programa, existe a concentração de recursos em grupos de estados e regiões brasileiras. O Centro-Oeste e o Sudeste receberam a maior parcela dos empréstimos. As regiões Norte e Nordeste receberam as menores quantidades de empréstimos, regiões estas que deveriam ser priorizadas devido à baixa eficiência das atividades agropecuárias. É possível ressaltar que certa parcela dos recursos do ABC aplicados no Norte e Nordeste concentram-se nos estados do MATOPIBA, que possuem parte do seu território no bioma do Cerrado, caracterizado por apresentar melhores condições de APT do que a Caatinga.

As duas regiões que possuem maior quantidade de hectares atingidos pelo Programa $\mathrm{ABC}$, o Centro-Oeste e Sul, contam com algumas características peculiares quanto a esta variável. Estas peculiaridades foram citadas na seção 3.1 deste texto. Informações sobre a área dos contratos são analisadas através da Tabela 5, que apresenta os valores médios dos contratos (crédito concedido dividido pelo total de contratos) e valores médios por hectare (crédito concedido dividido pela área).

Nas regiões Norte, Nordeste e Centro-Oeste todos os subprogramas de maior relevância obtiveram valor médio de contrato superior à média nacional. Dos estados participantes destas regiões, poucos obtiveram valor médio por contrato inferior ao valor médio total.

Ao analisar os valores médios de RPD, SPD, FLP e iLPF das regiões Sudeste e Sul observa-se que estes foram inferiores à média nacional. Apenas o RPD no ES, SPD em MG e iLPF em RS superaram a média nacional. Do montante de quase R $\$ 4,17$ bilhões de crédito concedido unificando ambas as regiões, apenas cerca de $\mathrm{R} \$ 0,39$ bilhão foram distribuídos acima da média.

As regiões Norte, Nordeste e Centro-Oeste possuem vastas áreas caracterizadas pela baixa APT. Espera-se que as áreas de baixa APT demandem maior quantidade de insumos para correção do solo, bem como apresentem riscos elevados associados à produção agropecuária. Portanto, a verificação de maiores valores médios dos contratos no Norte, Nordeste e Centro-Oeste do que o realizado no Sudeste e Sul era uma característica esperada, mesmo que esta relação não esteja contemplada explicitamente no Plano ABC.

Quanto aos valores por hectare, verifica-se elevada dispersão dos resultados em alguns subprogramas, em especial em iLPF, FLP e nos que contam com menores números de observações como TDA, FBN, ARA e OUT. Salientadas as deficiências da base de dados quanto à área dos contratos, é possível realizar breve análise dos resultados neste quesito. Salvo as exceções apontadas, os valores médios por hectare do Brasil são fortemente 
influenciados pelo resultado do Sudeste. Segundo a lógica das necessidades de recursos tratada no parágrafo anterior, os maiores valores médios por hectare deveriam ser destinados às regiões Norte, Nordeste e Centro-Oeste. No entanto, a alocação dos valores por hectare parece totalmente equivocada com as regiões de maiores deficiências na produção agropecuária.

Após esta apresentação geral das características observadas dos subprogramas nas regiões brasileiras, é possível apresentar a divisão intrarregional do crédito, área e quantidade de contratos de acordo com a APT, representada resumidamente no Tabela $6^{15}$. Nas Figuras 3 , 4, 5, 6 e 7 são apresentados mapas da distribuição de crédito dos subprogramas de RPD, SPD, FLP e iLPF. Como exemplificado anteriormente na seção 3.1, a APT é dividida em quatro classificações: "A" alta, "B" média", "C" baixa e "D" muito baixa. As APT "C" e "D" foram agrupadas em apenas uma classificação de APT baixas “CD”.

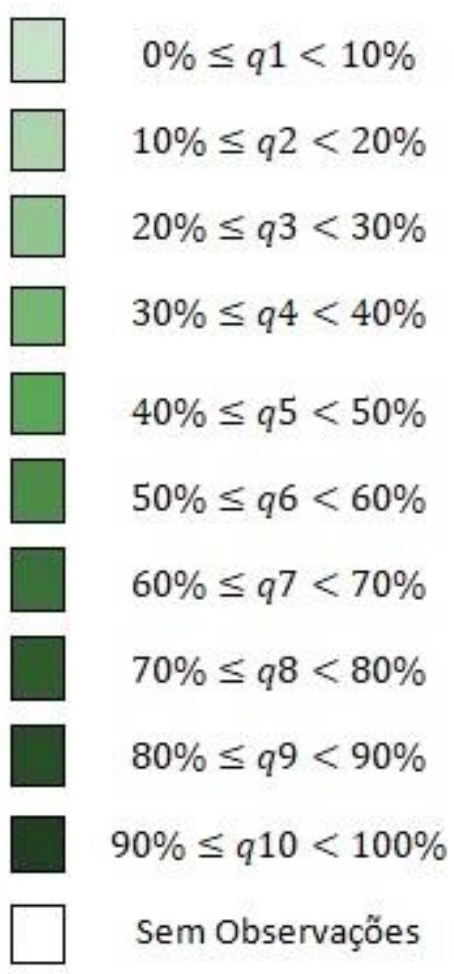

Figura 3. Legenda de Cores dos Mapas de Quantil

Fonte: resultados da pesquisa.

15 As Tabelas 16, 17 e 18 representam estas informações completas, estes foram reservados ao anexo e substituídos pela Tabela 6 e representação através dos mapas para facilitar o entendimento do leitor. 
O Brasil registrou distribuição de crédito concedido e quantidade de contratos similar entre as diferentes APT. A distribuição de área distinguiu-se das demais variáveis devido às peculiaridades da base de dados. Em geral, os subprogramas apresentam grande variabilidade na importância da APT de acordo com o critério e região observada.

Observando a APT nas distribuições intrarregionais apenas o Nordeste e o Sul possuem os municípios de baixa APT como principal destino dos recursos, mas ainda assim, contrastado com elevada aquisição destes recursos em áreas de alta APT, principalmente no Nordeste. O Norte e Centro-Oeste são mais participativos em municípios de predominância da média APT, mas vale ressaltar que o Norte possui grande alocação de recursos em municípios de baixa APT, um avanço frente ao Centro-Oeste, em que mais de um quarto dos recursos destinaram-se a municípios de alta APT. No Sudeste os recursos foram alocados em classificação totalmente inversa do que se espera para estimular as mitigações de GEE, ou seja, maior parcela foi alocada em municípios caracterizados pela alta ATP.

Certos estados destacaram-se ao observar a distribuição de crédito pela característica de APT. Entre estes, AP, RR, MA, PE, PI, RJ e SC destacam-se pela alocação eficiente dos recursos, com parcelas destinadas para municípios de predominância de baixa APT superiores a $85 \%$. Quanto os estados da BA, MS e SP, apresentam alocação menos eficiente, com participações intrarregionais superiores a 50\% em municípios caracterizados pela alta APT.

Os estados supracitados, que alocaram de forma mais eficiente os recursos de acordo com as propostas ambientais do Plano $\mathrm{ABC}$, possuem soma dos recursos realizados em áreas de baixa APT inferiores a 5\% do total dos empréstimos realizados pelo Programa ABC.

Entre a BA, MS e SP aproximadamente 16,7\% do total do crédito concedido pelo $\mathrm{ABC}$ foram destinados para alta APT. Especialmente a realização de investimentos do ABC em áreas de alta APT no Nordeste, ocasiona um grande desvio sobre as propostas ambientais do $\mathrm{ABC}$, pois, nesta região existem vastas áreas de baixa produtividade que poderiam ser beneficiadas.

Em paralelo com a análise da distribuição intrarregional do Programa ABC, a alocação dos recursos em relação ao total exercido no Brasil (Tabela $7^{16}$ ) mantém as relações verificadas a nível estadual, no entanto, seus percentuais são traduzidos em relação ao total realizado no país. Com isto, mesmo que uma região obtenha elevada concentração intrarregional de contratos em determinado subprograma e/ou APT, pode não obter tamanha relevância para os subprogramas de acordo com o total do país. Este fato ocorre 
principalmente nas regiões Norte, Nordeste e Sul, as quais compõem menores parcelas dos recursos totais do Programa. 
Tabela 6. Crédito concedido, área e quantidade de contratos por subprogramas, regiões e APT, em relação ao total das regiões. Em porcentagem (\%).

\begin{tabular}{|c|c|c|c|c|c|c|c|c|c|c|c|c|c|c|c|c|c|c|c|c|c|c|c|c|c|}
\hline \multirow{2}{*}{ Região } & \multicolumn{8}{|c|}{ Apt. A } & \multicolumn{8}{|c|}{ Apt. B } & \multicolumn{8}{|c|}{ Apt. CD } & \multirow{2}{*}{ TOTAL } \\
\hline & RPD & SPD & iLPF & FLP & ARA & TDA & OUT & Total & RPD & SPD & iLPF & FLP & ARA & TDA & OUT & Total & RPD & SPD & iLPF & FLP & ARA & TDA & OUT & Total & \\
\hline \multicolumn{26}{|c|}{ Crédito Concedido } \\
\hline Norte & 0,9 & 0,0 & 0,0 & 0,2 & 0,0 & 0,1 & 0,2 & 1,3 & 46,2 & 4,6 & 0,7 & 1,2 & 0,0 & 0,0 & 3,3 & 56,0 & 24,7 & 8,1 & 1,8 & 3,5 & 0,0 & 0,0 & 4,6 & 42,7 & 100 \\
\hline Nordeste & 4,5 & 28,6 & 2,0 & 1,6 & 0,0 & 0,0 & 0,2 & 37,0 & 5,1 & 2,1 & 1,2 & 2,0 & 0,0 & 0,0 & 0,0 & 10,4 & 24,7 & 25,1 & 1,3 & 1,4 & 0,0 & 0,0 & 0,0 & 52,6 & 100 \\
\hline Centro-Oeste & 11,7 & 11,0 & 1,3 & 2,7 & 0,0 & 0,0 & 0,5 & 27,3 & 28,8 & 10,6 & 2,9 & 2,6 & 0,0 & 0,0 & 0,2 & 45,1 & 16,4 & 2,3 & 2,3 & 6,6 & 0,0 & 0,0 & 0,1 & 27,6 & 100 \\
\hline Sudeste & 17,9 & 11,6 & 3,9 & 7,9 & 0,0 & 0,1 & 0,0 & 41,4 & 15,8 & 6,6 & 4,7 & 7,7 & 0,0 & 0,1 & 0,0 & 34,9 & 13,3 & 2,2 & 2,8 & 5,1 & 0,0 & 0,2 & 0,0 & 23,7 & 100 \\
\hline Sul & 12,3 & 8,3 & 1,1 & 1,7 & 0,0 & 0,3 & 0,0 & 23,8 & 8,9 & 14,2 & 1,8 & 2,6 & 0,7 & 0,0 & 0,0 & 28,1 & 22,3 & 12,2 & 4,3 & 8,2 & 0,1 & 1,0 & 0,0 & 48,1 & 100 \\
\hline Brasil & 11,8 & 11,3 & 2,0 & 3,8 & 0,0 & 0,1 & 0,2 & 29,3 & 22,2 & 8,2 & 2,9 & 4,0 & 0,1 & 0,0 & 0,5 & 38,0 & 17,8 & 6,2 & 2,5 & 5,5 & 0,0 & 0,2 & 0,6 & 32,8 & 100 \\
\hline \multicolumn{26}{|c|}{ Área } \\
\hline Norte & 0,5 & 0,0 & 0,0 & 0,1 & 0,0 & 0,0 & 0,0 & 0,6 & 39,5 & 7,8 & 1,2 & 0,7 & 0,0 & 0,0 & 1,0 & 50,2 & 25,6 & 16,2 & 2,4 & 3,2 & 0,0 & 0,0 & 1,9 & 49,2 & 100 \\
\hline Nordeste & 3,5 & 38,4 & 0,6 & 0,8 & 0,0 & 0,0 & 0,0 & 43,3 & 2,9 & 2,9 & 0,4 & 0,4 & 0,0 & 0,0 & 0,0 & 6,5 & 12,2 & 36,1 & 0,5 & 1,3 & 0,0 & 0,0 & 0,0 & 50,2 & 100 \\
\hline Centro-Oeste & 6,0 & 10,6 & 0,6 & 1,0 & 0,0 & 0,0 & 0,3 & 18,6 & 16,5 & 10,2 & 38,6 & 0,9 & 0,0 & 0,0 & 0,4 & 66,6 & 9,3 & 2,2 & 1,2 & 2,0 & 0,0 & 0,0 & 0,1 & 14,8 & 100 \\
\hline Sudeste & 17,4 & 9,8 & 2,2 & 8,3 & 0,0 & 0,0 & 0,0 & 37,8 & 14,8 & 11,3 & 2,9 & 7,0 & 0,6 & 0,0 & 0,0 & 36,5 & 16,5 & 3,0 & 1,7 & 4,4 & 0,0 & 0,0 & 0,0 & 25,7 & 100 \\
\hline Sul & 4,1 & 9,3 & 19,7 & 0,3 & 0,0 & 0,0 & 0,0 & 33,5 & 3,4 & 13,9 & 1,2 & 0,7 & 0,0 & 0,0 & 0,0 & 19,2 & 8,2 & 11,5 & 1,4 & 26,1 & 0,0 & 0,0 & 0,0 & 47,3 & 100 \\
\hline Brasil & 6,5 & 12,0 & 4,8 & 1,8 & 0,0 & 0,0 & 0,2 & 25,2 & 14,2 & 10,2 & 18,9 & 1,6 & 0,1 & 0,0 & 0,3 & 45,3 & 11,8 & 8,7 & 1,3 & 7,4 & 0,0 & 0,0 & 0,2 & 29,4 & 100 \\
\hline \multicolumn{26}{|c|}{ Contratos } \\
\hline Norte & 1,2 & 0,0 & 0,0 & 0,2 & 0,0 & 0,1 & 0,1 & 1,5 & 47,5 & 4,4 & 0,6 & 1,1 & 0,1 & 0,0 & 1,5 & 55,1 & 29,8 & 8,2 & 1,7 & 2,6 & 0,0 & 0,0 & 1,1 & 43,4 & 100 \\
\hline Nordeste & 5,2 & 22,2 & 1,4 & 1,6 & 0,0 & 0,0 & 0,1 & 30,4 & 6,2 & 2,2 & 1,1 & 2,2 & 0,0 & 0,0 & 0,0 & 11,7 & 35,6 & 19,0 & 1,5 & 1,8 & 0,0 & 0,0 & 0,1 & 57,9 & 100 \\
\hline Centro-Oeste & 15,4 & 9,8 & 0,9 & 2,1 & 0,0 & 0,0 & 0,2 & 28,5 & 34,7 & 10,0 & 2,0 & 2,1 & 0,0 & 0,0 & 0,2 & 49,1 & 17,9 & 2,3 & 0,9 & 1,3 & 0,0 & 0,0 & 0,1 & 22,4 & 100 \\
\hline Sudeste & 19,7 & 10,7 & 3,5 & 8,4 & 0,0 & 0,0 & 0,0 & 42,4 & 15,6 & 4,9 & 3,9 & 7,3 & 0,0 & 0,0 & 0,0 & 31,7 & 16,6 & 1,3 & 2,7 & 5,0 & 0,0 & 0,2 & 0,0 & 25,9 & 100 \\
\hline Sul & 9,0 & 11,2 & 0,8 & 2,5 & 0,0 & 0,2 & 0,0 & 23,6 & 7,8 & 15,4 & 1,3 & 2,5 & 0,2 & 0,0 & 0,0 & 27,1 & 21,0 & 15,8 & 3,7 & 8,1 & 0,1 & 0,6 & 0,0 & 49,2 & 100 \\
\hline Brasil & 13,9 & 10,4 & 1,9 & 4,4 & 0,0 & 0,1 & 0,1 & 30,8 & 21,9 & 7,7 & 2,4 & 4,1 & 0,1 & 0,0 & 0,2 & 36,5 & 20,3 & 5,9 & 2,2 & 4,0 & 0,0 & 0,2 & 0,1 & 32,8 & 100 \\
\hline
\end{tabular}

Fonte: resultados da pesquisa. 
Após esta caracterização das distribuições intrarregionais e totais dos recursos do Programa $\mathrm{ABC}$, ampliam-se as discussões sobre a priorização de destino dos recursos do Programa $\mathrm{ABC}$ para regiões de maior carência em eficiência agropecuária e, portanto, maior potencial de mitigação de GEE.
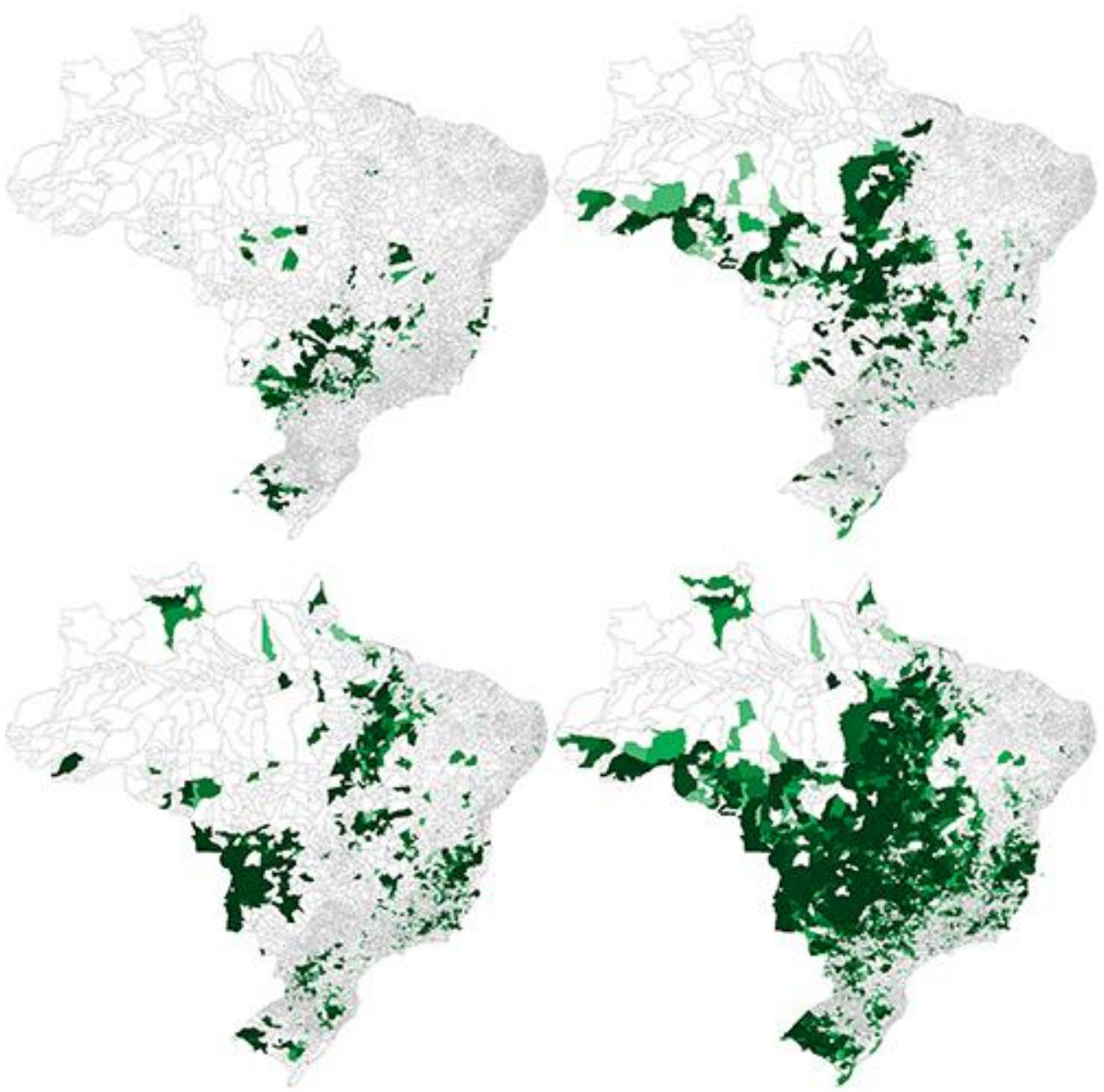

Figura 4. Distribuição do crédito em RPD nos municípios brasileiros. Mapas superiores da APT "A" e "B", inferiores da "CD" e do total.

Fonte: resultados da pesquisa

As regiões Norte e Nordeste, devido à concentração de áreas de baixa APT, são apontadas como as de maiores necessidades de investimentos do $\mathrm{ABC}$, mas são as que menos recebem recursos. Isto foi retratado nos demais trabalhos sobre o Plano e Programa $\mathrm{ABC}$ apresentados em seção anterior e também constatados nesta pesquisa. Além disto, os resultados desta mostram que mesmo os recursos que estão sendo alocados nestas regiões poderiam ser utilizados de maneira mais eficiente em vista da presença de muitos contratos em municípios de predominância de alta e média APT. 
Tabela 7. Crédito concedido, área e quantidade de contratos por subprogramas, regiões e APT em relação ao total do Brasil. Em porcentagem (\%).

\begin{tabular}{|c|c|c|c|c|c|c|c|c|c|c|c|c|c|c|c|c|c|c|c|c|c|c|c|c|c|}
\hline \multirow{2}{*}{ Região } & \multicolumn{8}{|c|}{ Apt. A } & \multicolumn{8}{|c|}{ Apt. B } & \multicolumn{8}{|c|}{ Apt. CD } & \multirow{2}{*}{ TOTAL } \\
\hline & RPD & SPD & iLPF & FLP & ARA & TDA & OUT & Total & RPD & SPD & iLPF & FLP & ARA & TDA & OUT & Total & RPD & SPD & iLPF & FLP & ARA & TDA & OUT & Total & \\
\hline \multicolumn{26}{|c|}{ Crédito Concedido } \\
\hline Norte & 0,1 & 0,0 & 0,0 & 0,0 & 0,0 & 0,0 & 0,0 & 0,2 & 5,3 & 0,5 & 0,1 & 0,1 & 0,0 & 0,0 & 0,4 & 6,4 & 2,8 & 0,9 & 0,2 & 0,4 & 0,0 & 0,0 & 0,5 & 4,9 & 11,5 \\
\hline Nordeste & 0,4 & 2,7 & 0,2 & 0,2 & 0,0 & 0,0 & 0,0 & 3,5 & 0,5 & 0,2 & 0,1 & 0,2 & 0,0 & 0,0 & 0,0 & 1,0 & 2,3 & 2,4 & 0,1 & 0,1 & 0,0 & 0,0 & 0,0 & 5,0 & 9,5 \\
\hline Centro-Oeste & 4,3 & 4,0 & 0,5 & 1,0 & 0,0 & 0,0 & 0,2 & 10,0 & 10,5 & 3,9 & 1,1 & 1,0 & 0,0 & 0,0 & 0,1 & 16,5 & 6,0 & 0,8 & 0,8 & 2,4 & 0,0 & 0,0 & 0,0 & 10,1 & 36,5 \\
\hline Sudeste & 5,6 & 3,6 & 1,2 & 2,5 & 0,0 & 0,0 & 0,0 & 13,0 & 5,0 & 2,1 & 1,5 & 2,4 & 0,0 & 0,0 & 0,0 & 11,0 & 4,2 & 0,7 & 0,9 & 1,6 & 0,0 & 0,1 & 0,0 & 7,4 & 31,4 \\
\hline Sul & 1,4 & 0,9 & 0,1 & 0,2 & 0,0 & 0,0 & 0,0 & 2,6 & 1,0 & 1,6 & 0,2 & 0,3 & 0,1 & 0,0 & 0,0 & 3,1 & 2,5 & 1,4 & 0,5 & 0,9 & 0,0 & 0,1 & 0,0 & 5,4 & 11,1 \\
\hline Brasil & 11,8 & 11,3 & 2,0 & 3,8 & 0,0 & 0,1 & 0,2 & 29,3 & 22,2 & 8,2 & 2,9 & 4,0 & 0,1 & 0,0 & 0,5 & 38,0 & 17,8 & 6,2 & 2,5 & 5,5 & 0,0 & 0,2 & 0,6 & 32,8 & 100,0 \\
\hline \multicolumn{26}{|c|}{ Área } \\
\hline Norte & 0,0 & 0,0 & 0,0 & 0,0 & 0,0 & 0,0 & 0,0 & 0,1 & 3,4 & 0,7 & 0,1 & 0,1 & 0,0 & 0,0 & 0,1 & 4,3 & 2,2 & 1,4 & 0,2 & 0,3 & 0,0 & 0,0 & 0,2 & 4,2 & 8,5 \\
\hline Nordeste & 0,3 & 3,7 & 0,1 & 0,1 & 0,0 & 0,0 & 0,0 & 4,1 & 0,3 & 0,3 & 0,0 & 0,0 & 0,0 & 0,0 & 0,0 & 0,6 & 1,2 & 3,5 & 0,1 & 0,1 & 0,0 & 0,0 & 0,0 & 4,8 & 9,5 \\
\hline Centro-Oeste & 2,8 & 5,0 & 0,3 & 0,5 & 0,0 & 0,0 & 0,2 & 8,7 & 7,8 & 4,8 & 18,1 & 0,4 & 0,0 & 0,0 & 0,2 & 31,3 & 4,4 & 1,0 & 0,5 & 0,9 & 0,0 & 0,0 & 0,0 & 6,9 & 47,0 \\
\hline Sudeste & 2,4 & 1,4 & 0,3 & 1,2 & 0,0 & 0,0 & 0,0 & 5,3 & 2,1 & 1,6 & 0,4 & 1,0 & 0,1 & 0,0 & 0,0 & 5,1 & 2,3 & 0,4 & 0,2 & 0,6 & 0,0 & 0,0 & 0,0 & 3,6 & 14,0 \\
\hline Sul & 0,9 & 1,9 & 4,1 & 0,1 & 0,0 & 0,0 & 0,0 & 7,0 & 0,7 & 2,9 & 0,2 & 0,1 & 0,0 & 0,0 & 0,0 & 4,0 & 1,7 & 2,4 & 0,3 & 5,5 & 0,0 & 0,0 & 0,0 & 9,9 & 20,9 \\
\hline Brasil & 6,5 & 12,0 & 4,8 & 1,8 & 0,0 & 0,0 & 0,2 & 25,2 & 14,2 & 10,2 & 18,9 & 1,6 & 0,1 & 0,0 & 0,3 & 45,3 & 11,8 & 8,7 & 1,3 & 7,4 & 0,0 & 0,0 & 0,2 & 29,4 & 100,0 \\
\hline \multicolumn{26}{|c|}{ Contratos } \\
\hline Norte & 0,1 & 0,0 & 0,0 & 0,0 & 0,0 & 0,0 & 0,0 & 0,1 & 4,5 & 0,4 & 0,1 & 0,1 & 0,0 & 0,0 & 0,1 & 5,3 & 2,8 & 0,8 & 0,2 & 0,2 & 0,0 & 0,0 & 0,1 & 4,1 & 9,5 \\
\hline Nordeste & 0,4 & 1,7 & 0,1 & 0,1 & 0,0 & 0,0 & 0,0 & 2,3 & 0,5 & 0,2 & 0,1 & 0,2 & 0,0 & 0,0 & 0,0 & 0,9 & 2,7 & 1,4 & 0,1 & 0,1 & 0,0 & 0,0 & 0,0 & 4,3 & 7,5 \\
\hline Centro-Oeste & 4,2 & 2,7 & 0,2 & 0,6 & 0,0 & 0,0 & 0,1 & 7,8 & 9,4 & 2,7 & 0,5 & 0,6 & 0,0 & 0,0 & 0,1 & 13,4 & 4,9 & 0,6 & 0,2 & 0,3 & 0,0 & 0,0 & 0,0 & 6,1 & 27,2 \\
\hline Sudeste & 7,8 & 4,2 & 1,4 & 3,3 & 0,0 & 0,0 & 0,0 & 16,8 & 6,2 & 1,9 & 1,5 & 2,9 & 0,0 & 0,0 & 0,0 & 12,6 & 6,6 & 0,5 & 1,1 & 2,0 & 0,0 & 0,1 & 0,0 & 10,2 & 39,6 \\
\hline Sul & 1,5 & 1,8 & 0,1 & 0,4 & 0,0 & 0,0 & 0,0 & 3,8 & 1,3 & 2,5 & 0,2 & 0,4 & 0,0 & 0,0 & 0,0 & 4,4 & 3,4 & 2,6 & 0,6 & 1,3 & 0,0 & 0,1 & 0,0 & 8,0 & 16,2 \\
\hline Brasil & 13,9 & 10,4 & 1,9 & 4,4 & 0,0 & 0,1 & 0,1 & 30,8 & 21,9 & 7,7 & 2,4 & 4,1 & 0,1 & 0,0 & 0,2 & 36,5 & 20,3 & 5,9 & 2,2 & 4,0 & 0,0 & 0,2 & 0,1 & 32,8 & 100,0 \\
\hline
\end{tabular}

Fonte: resultados da pesquisa. 
Duas considerações importantes podem ser realizadas antes de enfatizar à discussão da priorização das áreas de aplicação dos recursos do Programa, uma sobre as peculiaridades da caracterização da APT e outra da dificuldade de implementação da agropecuária em regiões de baixa APT.

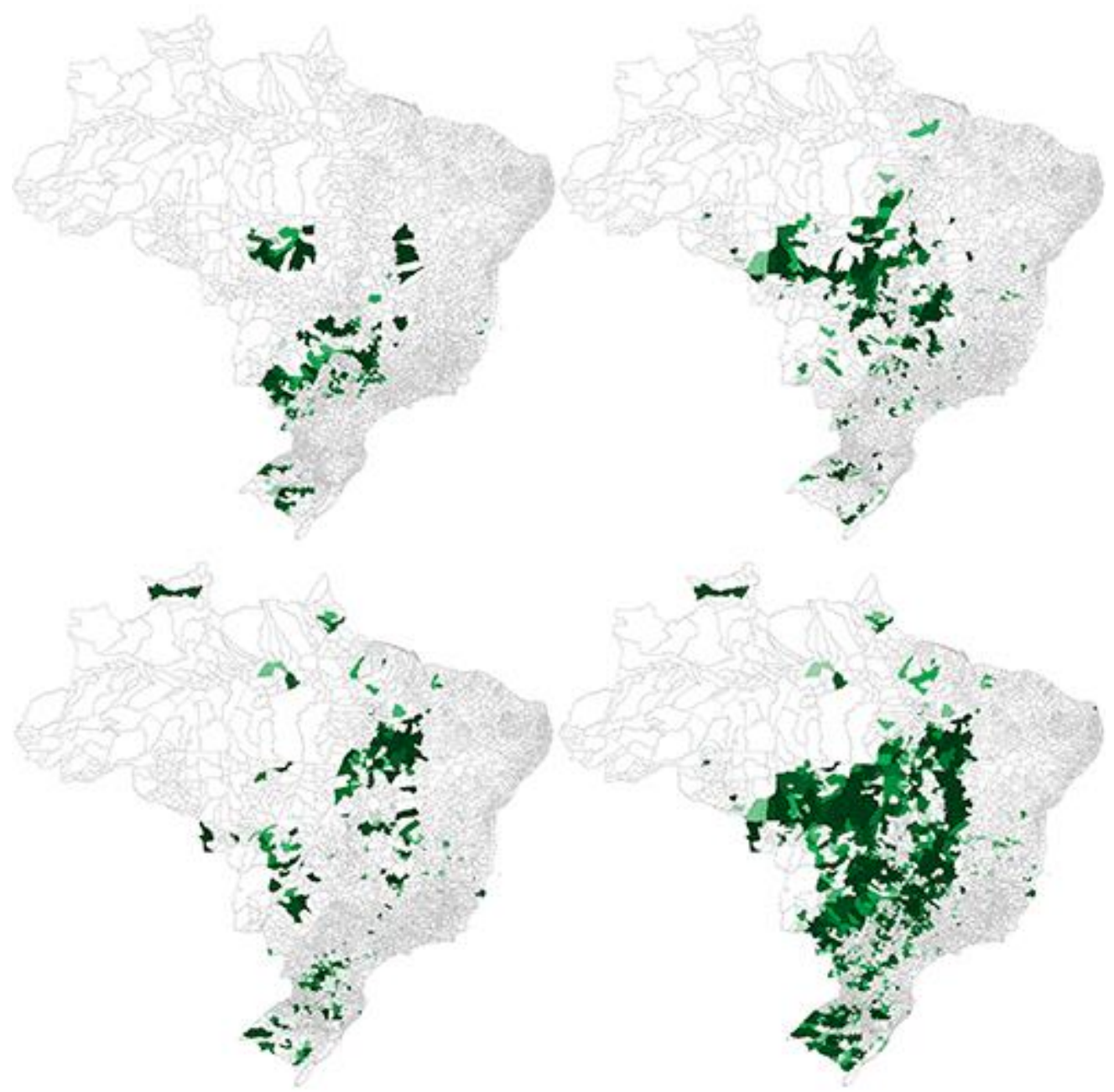

Figura 5. Distribuição do crédito em SPD nos municípios brasileiros. Mapas superiores da APT "A" e "B", inferiores da "CD" e do total.

Fonte: resultados da pesquisa

Primeiramente, a caracterização de APT de acordo com uma ponderação do total do município gera margens para que os recursos que foram implementados em municípios caracterizados como "A", estejam de fato sendo aplicados em uma parcela deste que esteja mais próxima de "CD", o contrário também é verdadeiro. Atualmente existem limitações quanto a base de dados que impedem que esta deficiência seja apurada.

Em segundo lugar, os municípios de predominância de baixa APT são referidos como prioritários no sentido de mitigação de GEE, no entanto, também são os locais onde a 
recuperação da pastagem e/ou solo seria mais custosa e difícil. Além das condições edafoclimáticas, existem aspectos econômicos, de logística, técnicos, entre outros, que podem apresentar menor eficiência nestas regiões, principalmente ao observar as áreas localizadas no Norte e no Nordeste. Para que os investimentos sejam realizados nestas áreas devem existir maiores incentivos de maneira a compensar os custos e riscos.
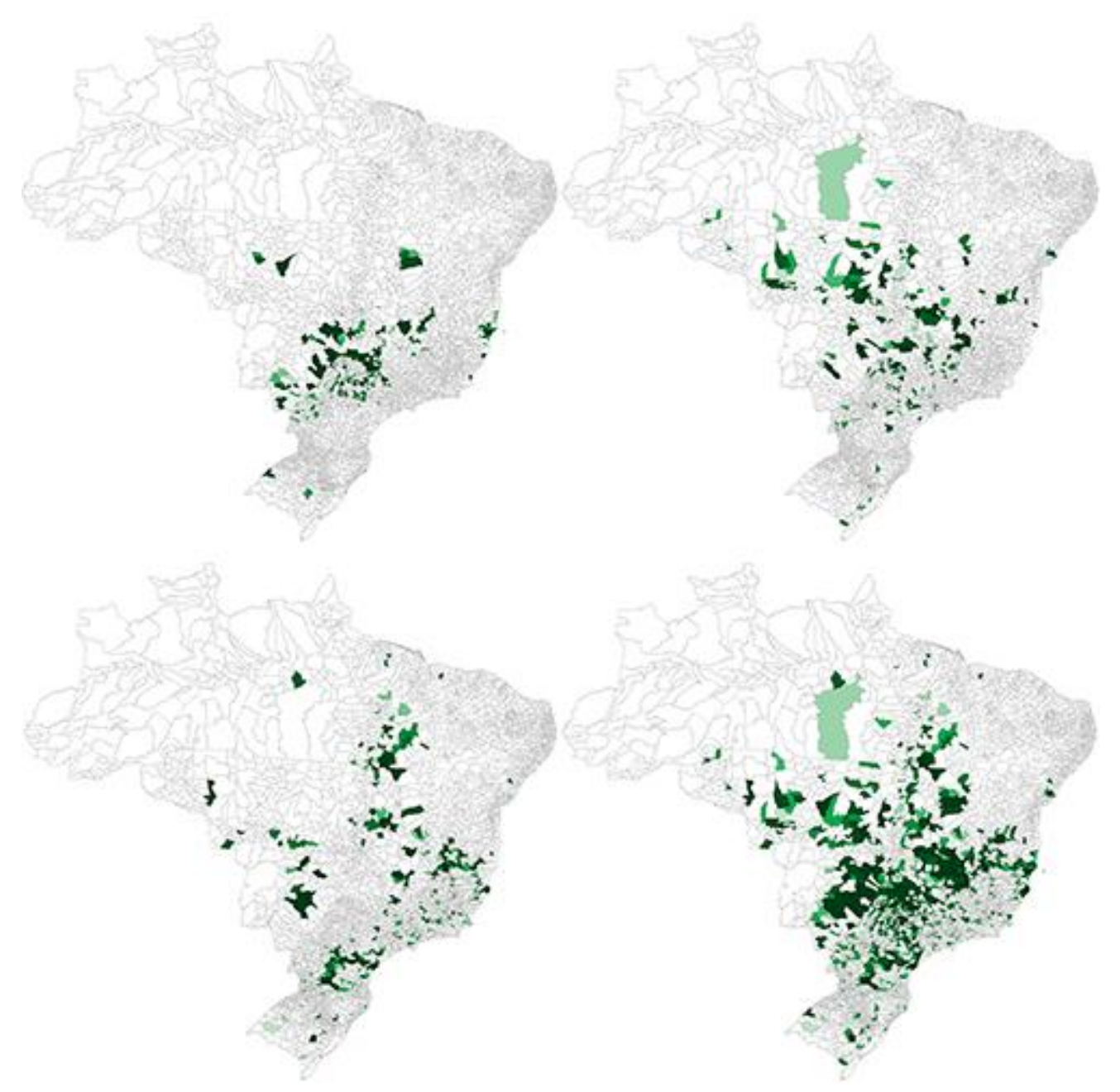

Figura 6. Distribuição do crédito em FLP nos municípios brasileiros. Mapas superiores da APT "A" e "B", inferiores da "CD" e do total.

Fonte: resultados da pesquisa

Em vista da dificuldade de implementação da agropecuária em locais de baixa APT, algumas características econômicas parecem se sobressair em relação às necessidades ambientais e de mitigação de carbono. Por este motivo pode ser explicada a maior contratação dos créditos do Programa ABC em municípios de predominância de alta e média APT, que geralmente possuem maior nível técnico e de eficiência produtiva. Neste sentido, a linha de crédito do $\mathrm{ABC}$ acaba por funcionar como qualquer outro mecanismo do crédito rural. No 
entanto, não se pode desconsiderar a vantagem do crédito do $\mathrm{ABC}$ de estimular, mesmo em regiões que já são produtivas, a adoção de técnicas mais eficientes, com diferencial de também proporcionarem impacto na mitigação de emissões de GEE. Como exemplo da associação de características econômicas aos empréstimos do $\mathrm{ABC}$, utilizando dados do Instituto Brasileiro de Geografia e Estatística (2017c) e realizando média das participações das regiões no rebanho bovino nacional de 1994 até 2015 obtêm-se a participação média do Norte de 17,7\%, Nordeste de 13,7\%, Centro-Oeste de 34,4\%, Sudeste de $20 \%$ e Sul de 14,3\%, comparando-se com as participações totais do Programa ABC, identifica-se associação, motivo pelo qual será realizado o teste de correlação de Spearman a nível municipal para algumas características econômicas, principalmente do agronegócio, para verificar esta relação.

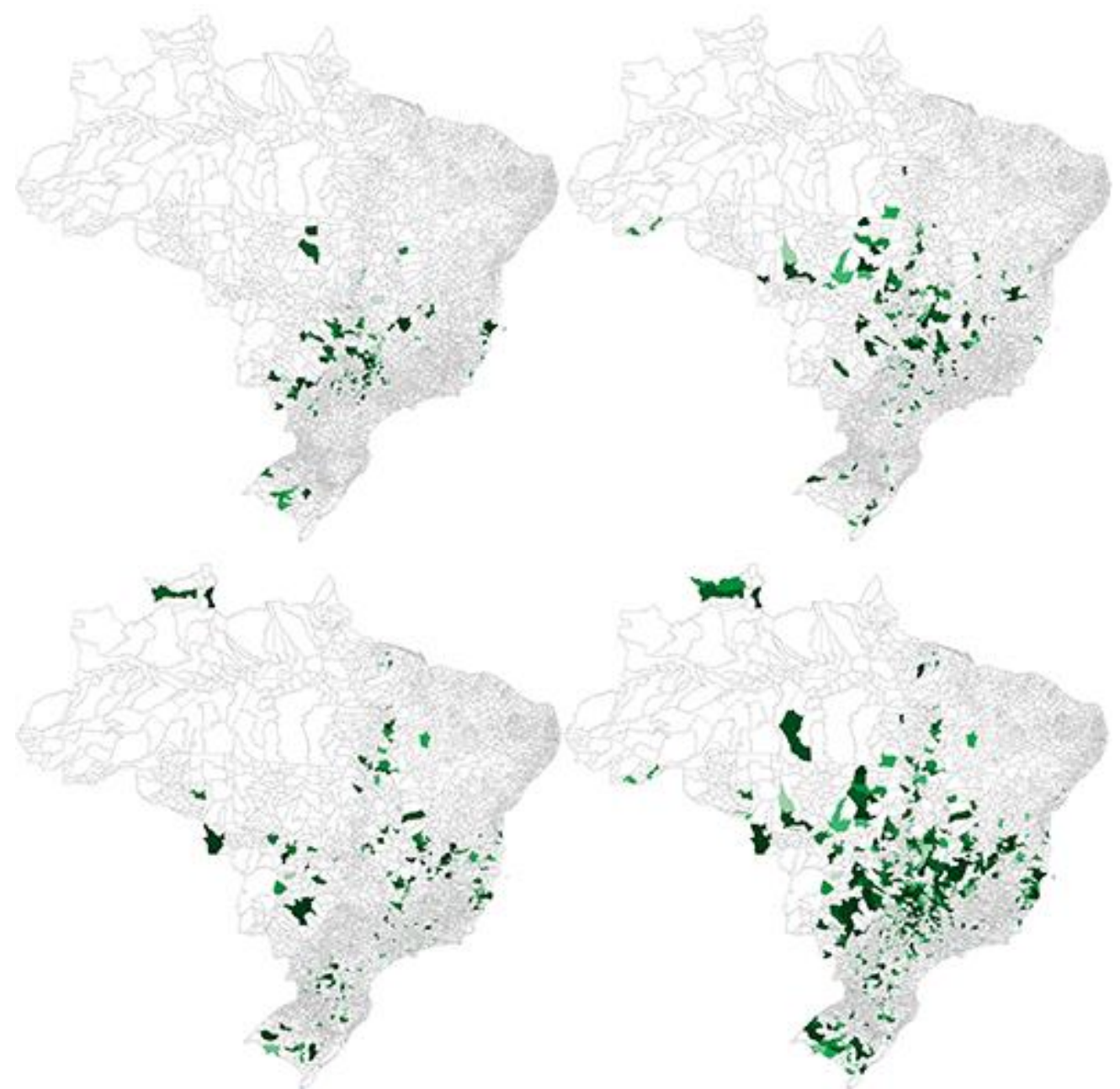

Figura 7. Distribuição do crédito em iLPF nos municípios brasileiros. Mapas superiores da APT "A" e "B", inferiores da "CD" e do total

Fonte: resultados da pesquisa 
Os recursos destinados aos municípios de predominância de média APT poderiam ser justificados, verificando-se que nestes municípios a correção da degradação do solo e pastagens têm maiores facilidades na obtenção de lucratividade e eficácia, ao mesmo tempo em que contribuem com a mitigação de emissões de GEE. Se analisados somente os esforços realizados nas regiões de maior impacto positivo em mitigação de GEE, caracterizadas pela baixa APT, a abrangência do Programa é diminuta. Ainda assim, destaca-se que a proposta do Plano ABC está em recuperar pastagens e áreas degradadas e implementar inovações no manejo tradicional da agropecuária nacional para mitigar a emissão de GEE e, para isto, será necessário recuperar justamente as regiões em que a degradação é mais extrema e a agropecuária é mais ineficiente. Este processo é custoso e para que seja possível de ocorrer, seria desejável que os municípios e regiões de baixa APT obtivessem políticas diferenciadas pelo Programa.

Na Tabela $8^{17}$ são mostradas as diferenças entre valores médios de contratos e valores médios por hectare de acordo com as características de APT das regiões e Unidades da Federação por subprogramas. Verificando os valores não foi possível determinar nenhum tipo de padrão. Como discutido, a variável de área e de valor médio por hectare apresenta alguns problemas de especificação. Reforçando a argumentação realizada anteriormente sobre a lógica desejável de aplicação dos recursos para atingir os objetivos ambientais do ABC, o observado através da Tabela 8 apresenta em diversos casos a relação inversa. Ou seja, as concessões das linhas do Programa $\mathrm{ABC}$ não priorizam distribuir maior volume de recursos de acordo com o cenário de APT. Destaca-se novamente, que esta característica de APT e volume de recursos destinados não é explícita no Plano $\mathrm{ABC}$, mas verifica-se a convergência desta e os objetivos traçados.

\subsection{Execução e Distribuição de Recursos do Plano e Programa ABC: Aptidão Agrícola e Atividades (Agrícola e Pecuária)}

As informações que são apresentadas nas Tabelas 9, 10 e 11 dizem respeito às especificidades da distribuição do Programa $\mathrm{ABC}$ de acordo com a atividade (agrícola ou pecuária), logo, utilizam os dados disponíveis na "Base 2".

17 Resultados completos disponíveis no Anexo III, Tabelas 22 e 23. 
Nas análises sobre as atividades produtivas, a distribuição da participação das regiões no crédito e na quantidade de observações intrarregionais é semelhante ${ }^{18}$, analogamente a distribuição do crédito e número dos contratos obtidos através da "Base 1". Ao comparar a participação das observações de cada atividade no total geral, existe predominância de observações na pecuária, mas na quantidade de crédito a distribuição é equivalente.

18 As Tabelas 27, 28, 29 e 30 contém as informações sobre o crédito e observações intrarregionais de acordo com a atividade e a Aptidão Agrícola. 
Tabela 8. Valores médios por contratos (em mil reais) e hectares (em reais) dos subprogramas, regiões e APT.

\begin{tabular}{|c|c|c|c|c|c|c|c|c|c|c|c|c|c|c|c|c|c|c|c|c|c|}
\hline \multirow{2}{*}{ Região } & \multicolumn{7}{|c|}{ Apt. A } & \multicolumn{7}{|c|}{ Apt. B } & \multicolumn{7}{|c|}{ Apt. CD } \\
\hline & RPD & SPD & iLPF & FLP & ARA & TDA & OUT & RPD & SPD & iLPF & FLP & ARA & TDA & OUT & RPD & SPD & iLPF & FLP & ARA & TDA & OUT \\
\hline \multicolumn{22}{|c|}{ Valor Médio Por Contrato } \\
\hline Norte & 438,8 & 0 & 0 & 573,3 & 0 & $1.132,20$ & 984,1 & 558 & 604,6 & 644,1 & 659,2 & 495,8 & 0 & $1.231,80$ & 474,8 & 566,1 & 604,8 & 781,3 & 0 & 0 & $2.352,20$ \\
\hline Nordeste & 526,3 & 782,4 & 882,7 & 614,7 & 0 & 0 & $2.000,00$ & 501 & 582,9 & 650,7 & 540 & 0 & 0 & 0 & 420,3 & 799,3 & 545,7 & 497,7 & 0 & 0 & 344 \\
\hline Centro-Oeste & 485,1 & 715,9 & 985,5 & 835,6 & 378,5 & $1.199,50$ & $1.163,40$ & 529,8 & 672,6 & 924,6 & 798,6 & 136,3 & 382 & 654 & 587 & 627,9 & $1.584,10$ & $3.348,70$ & 0 & 0 & 659,8 \\
\hline Sudeste & 343,4 & 407,6 & 419,5 & 352,9 & 98,4 & 690,2 & 0 & 383 & 510,2 & 462,3 & 399 & 64,4 & 560,3 & 0 & 303,8 & 650,7 & 383,2 & 382 & 117,5 & 447,4 & 183,6 \\
\hline Sul & 445,6 & 242,8 & 471,9 & 228,8 & 0 & 620,6 & 0 & 374,2 & 302,5 & 454,1 & 348,3 & 903,7 & 0 & 0 & 348,9 & 251,6 & 389,2 & 331,4 & 295,3 & 569,2 & 0 \\
\hline Brasil & 402,5 & 518,1 & 520,3 & 411,9 & 238,5 & 734,7 & $1.191,50$ & 484,7 & 507,4 & 576,6 & 461,2 & 625,1 & 500,9 & $1.057,10$ & 418,2 & 499,3 & 544,7 & 647,2 & 206,4 & 517,5 & $1.961,30$ \\
\hline \multicolumn{22}{|c|}{ Valor Médio Por Hectare } \\
\hline Norte & 4.055 & 0 & 0 & 4.047 & 0 & 0 & 17.308 & 2.753 & 1.389 & 1.356 & 4.078 & 2.929 & 0 & 7.949 & 2.268 & 1.182 & 1.750 & 2.624 & 0 & 0 & 5.648 \\
\hline Nordeste & 2.232 & 1.289 & 6.138 & 3.620 & 0 & 0 & 2.000 .000 & 3.090 & 1.284 & 5.774 & 7.691 & 0 & 0 & 0 & 3.514 & 1.199 & 4.341 & 1.855 & 0 & 0 & 6.735 \\
\hline Centro-Oeste & 2.613 & 1.402 & 3.223 & 3.616 & 5.260 & 0 & 1.921 & 2.354 & 1.396 & 102 & 4.122 & 3.376 & 0 & 742 & 2.380 & 1.371 & 2.617 & 4.539 & 0 & 0 & 1.352 \\
\hline Sudeste & 3.995 & 4.565 & 7.099 & 3.672 & 5.966 & 0 & 0 & 4.165 & 2.282 & 6.456 & 4.291 & 26 & 0 & 0 & 3.148 & 2.898 & 6.192 & 4.483 & 6.289 & 19.572 & 6.120 \\
\hline Sul & 2.747 & 826 & 53 & 4.806 & 0 & 0 & 0 & 2.378 & 945 & 1.413 & 3.577 & 16.512 & 0 & 0 & 2.513 & 975 & 2.908 & 291 & 9.842 & 0 & 0 \\
\hline Brasil & 3.139 & 1.639 & 747 & 3.700 & 5.392 & 0 & 2.357 & 2.728 & 1.402 & 271 & 4.267 & 1.418 & 0 & 2.822 & 2.642 & 1.237 & 3.270 & 1.285 & 8.479 & 53.368 & 4.905 \\
\hline
\end{tabular}

Fonte: resultados da pesquisa. 
Sobre a distribuição intrarregional dos investimentos, na pecuária, aproximadamente 93,5\% do crédito concedido são destinados para RPD, enquanto na agricultura o SPD corresponde a cerca de $51 \%$ do crédito, FLP a $25,5 \%$, iLPF a $12 \%$ e, por fim, RPD com aproximadamente $10 \%$.

As disparidades entre o número de observações e o volume de crédito indicam, que na pecuária, as modalidades adquiridas têm menor valor médio, ocorrendo o contrário na agricultura. A agricultura quando comparada à pecuária extensiva é uma atividade que necessita de maiores investimentos em maquinário, insumos e tecnologia para realização da produção. Acredita-se que mesmo nas linhas do Programa ABC, os investimentos realizados na modernização da agricultura necessitem de maiores montantes para serem implementados.

A Tabela 9 ilustra a divisão dentre cada um dos subprogramas na atividade agrícola ou pecuária com as participações da quantidade de crédito concedido em municípios de predominância da APT alta, média e baixa. Em relação aos quatro principais subprogramas (RPD, SPD, FLP e iLPF), a participação da APT segue um padrão tanto na atividade agrícola quanto na pecuária, com exceção do ocorrido no subprograma de RPD. Apenas os contratos de pecuária associados à iLPF e agrícolas vinculados a FLP foram predominantes em municípios de baixa APT.

Tabela 9. Participação no crédito concedido por subprograma, APT e atividade, em relação ao total do subprograma em cada atividade. Em porcentagem (\%)

\begin{tabular}{c|c|c|c|c|c|c|c|c}
\hline \multirow{2}{*}{ Subprograma } & \multicolumn{4}{|c|}{ Agrícola } & \multicolumn{4}{c}{ Pecuária } \\
\cline { 2 - 10 } & Apt. A & Apt. B & Apt. CD & TOTAL & Apt. A & Apt. B & Apt. CD & TOTAL \\
\hline RPD & 58,19 & 29,46 & 12,35 & 100 & 19,12 & 44,65 & 36,23 & 100 \\
\hline SPD & 44,24 & 31,72 & 24,05 & 100 & 43,71 & 26,99 & 29,30 & 100 \\
\hline iLPF & 27,96 & 41,97 & 30,06 & 100 & 26,12 & 33,57 & 40,30 & 100 \\
\hline FLP & 29,80 & 30,47 & 39,74 & 100 & 29,16 & 42,35 & 28,49 & 100 \\
\hline ARA & 5,79 & 86,39 & 7,81 & 100 & 0,00 & 84,77 & 15,23 & 100 \\
\hline TDA & 100 & 0 & 0 & 100 & 27,50 & 10,85 & 61,65 & 100 \\
\hline OUTROS & 40,63 & 26,05 & 33,32 & 100 & 2,50 & 44,66 & 52,84 & 100 \\
\hline TOTAL & 39,97 & 32,41 & 27,62 & 100 & 19,45 & 43,99 & 36,57 & 100 \\
\hline
\end{tabular}

Fonte: resultados da pesquisa.

Quanto ao percentual de crédito total conferido à agricultura (Tabela $10^{19}$ ) observa-se que o SPD é predominante em todas as regiões. As participações em RPD, FLP e iLPF estão concentradas no Centro-Oeste e Sudeste, com ênfase na última região. No crédito total da atividade agrícola as regiões de APT mais elevadas recebem maiores parcelas de recursos.

19 Informações completas disponíveis no Anexo AIV, Tabelas 31 e 32. 
Apenas nas regiões Norte e Sul o crédito agrícola vinculado a locais de baixa APT foram predominantes, no entanto, a representatividade destas no total empregado pelo ABC é baixa. 
Tabela 10. Crédito concedido e observações em atividade agrícola por subprogramas, regiões e APT, em relação ao total do Brasil. Em porcentagem (\%)

\begin{tabular}{|c|c|c|c|c|c|c|c|c|c|c|c|c|c|c|c|c|c|c|c|}
\hline \multirow{2}{*}{ Região } & \multicolumn{5}{|c|}{ Apt. A } & \multicolumn{5}{|c|}{ Apt. B } & \multicolumn{5}{|c|}{ Apt. CD } & \multirow{2}{*}{ APT. A } & \multirow{2}{*}{ APT. B } & \multirow{2}{*}{ APT. CD } & \multirow{2}{*}{ TOTAL } \\
\hline & RPD & SPD & iLPF & FLP & OUT* & RPD & SPD & iLPF & FLP & OUT* & RPD & SPD & iLPF & FLP & OUT* & & & & \\
\hline \multicolumn{20}{|c|}{ Crédito } \\
\hline Norte & 0 & 0 & 0 & 0 & 0 & 0,2 & 0,5 & 0 & 0,1 & 0 & 0,1 & 0,9 & 0,1 & 0,4 & 0,1 & 0 & 0,8 & 1,7 & 2,5 \\
\hline Nordeste & 0 & 2,8 & 0,2 & 0,2 & 0 & 0 & 0,2 & 0,1 & 0,2 & 0 & 0 & 2,4 & 0,1 & 0,1 & 0 & 3,1 & 0,5 & 2,7 & 6,3 \\
\hline Centro-Oeste & 0,4 & 3,9 & 0,4 & 0,9 & 0,2 & 0,3 & 3,8 & 0,8 & 0,8 & 0,1 & 0,2 & 0,7 & 0,6 & 2 & 0 & 5,8 & 5,8 & 3,5 & 15,2 \\
\hline Sudeste & 2,5 & 3,7 & 1,1 & 2,5 & 0 & 0,8 & 2,1 & 1,4 & 2,5 & 0 & 0,1 & 0,7 & 0,8 & 1,6 & 0 & 9,8 & 6,8 & 3,2 & 19,8 \\
\hline Sul & 0,1 & 0,9 & 0 & 0,2 & 0 & 0,2 & 1,5 & 0,2 & 0,3 & 0,1 & 0,2 & 1,4 & 0,3 & 0,9 & 0 & 1,2 & 2,3 & 2,8 & 6,4 \\
\hline Brasil & 3,0 & 11,3 & 1,7 & 3,8 & 0,3 & 1,5 & 8,1 & 2,5 & 3,9 & 0,2 & 0,6 & 6,1 & 1,8 & 5,1 & 0,2 & 20,1 & 16,3 & 13,9 & 50,2 \\
\hline \multicolumn{20}{|c|}{ Observações } \\
\hline Norte & 0 & 0 & 0 & 0 & 0 & 0 & 0,3 & 0,1 & 0,1 & 0 & 0 & 0,7 & 0,2 & 0,1 & 0,1 & 0 & 0,5 & 1,1 & 1,7 \\
\hline Nordeste & 0 & 1,4 & 0,1 & 0,1 & 0 & 0 & 0,1 & 0,1 & 0,1 & 0 & 0 & 1 & 0,1 & 0,1 & 0 & 1,6 & 0,3 & 1,2 & 3,1 \\
\hline Centro-Oeste & 0,1 & 1,9 & 0,2 & 0,3 & 0 & 0,1 & 2 & 0,5 & 0,3 & 0,1 & 0,1 & 0,4 & 0,2 & 0,2 & 0 & 2,6 & 3 & 0,8 & 6,4 \\
\hline Sudeste & 1,8 & 2,9 & 1,1 & 1,9 & 0 & 0,6 & 1,3 & 1,4 & 1,6 & 0 & 0,1 & 0,3 & 1,1 & 1,2 & 0 & 7,7 & 5 & 2,7 & 15,4 \\
\hline Sul & 0,1 & 1,3 & 0,1 & 0,2 & 0 & 0,1 & 1,8 & 0,3 & 0,2 & 0 & 0,1 & 1,8 & 0,4 & 0,8 & 0 & 1,6 & 2,4 & 3,1 & 7,1 \\
\hline Brasil & 2,0 & 7,4 & 1,5 & 2,5 & 0 & 0,8 & 5,6 & 2,3 & 2,3 & 0,1 & 0,3 & 4,2 & 2 & 2,4 & 0,1 & 13,5 & 11,2 & 9 & 33,7 \\
\hline
\end{tabular}

Fonte: resultados da pesquisa. 
As culturas agrícolas são mais sensíveis às condições edafoclimáticas e sua produção é mais complexa que a pecuária. Desta maneira, ocorre um aprofundamento na agricultura da implementação do crédito em regiões de maior APT. Esta relação será analisada com maior ênfase através da Correlação de Spearman.

Com exceção da região Sul, todas as demais obtiveram menor participação na quantidade de observações da atividade agrícola do Programa ABC (Tabela 10) do que apresentaram em crédito. Com relação à APT, os municípios caracterizados como de alta APT possuem maior quantidade de observações.

Observando o Tabela $11^{20}$, o subprograma de RPD compõe mais de $90 \%$ do crédito concedido e quantidade de observações da atividade pecuária. Neste caso, a pequena participação relativa dos demais subprogramas frente à RPD, permite analisar os principais resultados através do agregado dos subprogramas nos grupos de APT (colunas APT. A, APT. $B$ e APT. CD).

$\mathrm{Na}$ atividade da pecuária, a maior participação no crédito é de municípios de média APT, e a menor nos municípios de alta APT. Apenas no Nordeste e Sul os municípios de baixa APT possuem maior participação no volume total de crédito. No entanto, são também as duas menores regiões no total de crédito à pecuária. A soma do volume de crédito destinado a municípios de APT "CD” do Nordeste e Sul representa menos de 5\% do crédito total do Programa ABC. A participação da atividade pecuária no número de observações totais é superior ao seu percentual de crédito em todas as regiões, exceto no Centro-Oeste.

Nos empréstimos vinculados a atividade pecuária a priorização dos investimentos de acordo com o potencial de mitigação de GEE ocorreu de maneira mais eficiente do que na agricultura. Houve realização de maior parcela de investimentos em atividade de pecuária nos municípios de predominância da baixa APT do que o observado na atividade agrícola. Na atividade pecuária os municípios caracterizados pela média APT foram predominantes na contratação do Programa ABC. Como discutido anteriormente, os municípios de média APT aliam potencialidades econômicas e benefícios ambientais razoáveis.

20 Informações completas disponíveis no Anexo AIV, Tabelas 33 e 34. 
Tabela 11. Crédito concedido e observações em atividade pecuária por subprogramas, regiões e APT, em relação ao total do Brasil. Em porcentagem (\%)

\begin{tabular}{|c|c|c|c|c|c|c|c|c|c|c|c|c|c|c|c|c|c|c|c|}
\hline \multirow{2}{*}{ Região } & \multicolumn{5}{|c|}{ Apt. A } & \multicolumn{5}{|c|}{ Apt. B } & \multicolumn{5}{|c|}{ Apt. CD } & \multirow{2}{*}{ APT. A } & \multirow{2}{*}{ APT. B } & \multirow{2}{*}{ APT. CD } & \multirow{2}{*}{ TOTAL } \\
\hline & RPD & SPD & iLPF & FLP & OUT* & RPD & SPD & iLPF & FLP & OUT* & RPD & SPD & iLPF & FLP & OUT* & & & & \\
\hline \multicolumn{20}{|c|}{ Crédito } \\
\hline Norte & 0,1 & 0 & 0 & 0 & 0 & 5,1 & 0 & 0 & 0 & 0,4 & 2,7 & 0 & 0 & 0 & 0,4 & 0,1 & 5,6 & 3,2 & 8,9 \\
\hline Nordeste & 0,4 & 0 & 0 & 0 & 0 & 0,5 & 0 & 0 & 0 & 0 & 2,2 & 0 & 0 & 0 & 0 & 0,4 & 0,5 & 2,3 & 3,2 \\
\hline Centro-Oeste & 3,9 & 0,2 & 0,1 & 0,1 & 0 & 10,3 & 0,1 & 0,2 & 0,1 & 0 & 5,6 & 0,1 & 0,1 & 0,1 & 0 & 4,3 & 10,7 & 5,9 & 20,9 \\
\hline Sudeste & 3,2 & 0,1 & 0,1 & 0 & 0 & 4,1 & 0 & 0 & 0 & 0 & 4,2 & 0 & 0 & 0 & 0,1 & 3,4 & 4,3 & 4,3 & 12 \\
\hline Sul & 1,3 & 0 & 0,1 & 0 & 0 & 0,8 & 0 & 0,1 & 0 & 0 & 2,2 & 0 & 0,2 & 0 & 0,1 & 1,5 & 0,8 & 2,5 & 4,9 \\
\hline Brasil & 8,9 & 0,3 & 0,3 & 0,1 & 0,1 & 20,8 & 0,2 & 0,3 & 0,2 & 0,4 & 16,8 & 0,2 & 0,4 & 0,1 & 0,6 & 9,7 & 21,9 & 18,2 & 49,8 \\
\hline \multicolumn{20}{|c|}{ Observações } \\
\hline Norte & 0,2 & 0 & 0 & 0 & 0 & 6,4 & 0 & 0 & 0 & 0,2 & 4,4 & 0 & 0 & 0 & 0,1 & 0,2 & 6,6 & 4,6 & 11,4 \\
\hline Nordeste & 0,6 & 0 & 0 & 0 & 0 & 0,7 & 0 & 0 & 0 & 0 & 4 & 0 & 0 & 0 & 0 & 0,6 & 0,7 & 4,1 & 5,4 \\
\hline Centro-Oeste & 4,3 & 0,1 & 0 & 0 & 0 & 9,3 & 0 & 0,1 & 0 & 0 & 5,1 & 0,1 & 0 & 0 & 0 & 4,4 & 9,6 & 5,2 & 19,3 \\
\hline Sudeste & 5,6 & 0,1 & 0,1 & 0 & 0 & 6,6 & 0,1 & 0 & 0,1 & 0 & 8,2 & 0 & 0 & 0 & 0,1 & 5,8 & 6,8 & 8,4 & 20,9 \\
\hline Sul & 2 & 0 & 0,1 & 0 & 0 & 1,6 & 0 & 0,1 & 0 & 0 & 5,1 & 0 & 0,2 & 0 & 0,1 & 2,2 & 1,6 & 5,4 & 9,3 \\
\hline Brasil & 12,7 & 0,1 & 0,3 & 0,1 & 0,1 & 24,6 & 0,1 & 0,2 & 0,1 & 0,2 & 26,8 & 0,1 & 0,3 & 0,1 & 0,3 & 13,3 & 25,4 & 27,6 & 66,3 \\
\hline
\end{tabular}

Fonte: resultados da pesquisa. 
Ainda que ocorra alocação mais fidedigna dos recursos da atividade pecuária de acordo com os objetivos ambientais do $\mathrm{ABC}$ do que o realizado na atividade agrícola, cerca de $9 \%$ do crédito total do Programa ABC representado por RPD em atividade de pecuária foi destinado para regiões de alta APT. Este volume é elevado, especialmente devido ao enquadramento mais específico da técnica de recuperação de pastagens e a necessidade de utilização desta técnica em áreas degradadas.

\subsection{Correlação de Spearman e Discussão para Ampliação da Eficácia e Eficiência do Plano e Programa ABC}

A identificação de motivações para a concentração dos empréstimos nos estados retratados, pode ser difícil devido a existência de várias regiões e grupos de municípios importantes, sejam estes em RPD, SPD, iLPF, FLP ou até mesmo nos demais subprogramas. A análise da Correlação de Spearman permite estudar a relação entre a produção agropecuária e a quantidade de crédito recebido do $\mathrm{ABC}$.

Observou-se anteriormente pouca convergência dos empréstimos do ABC nas regiões retratadas como prioritárias, resultados estes salientados pela baixa aderência dos contratos nos municípios categorizados como de baixa APT. A Correlação de Spearman representa outro instrumento de análise para verificar a robustez destas características apontadas.

A Tabela 12 apresenta os coeficientes de correlação obtidos através do método de Spearman para o total por grupo de APT e o total dos empréstimos do Programa ABC. Observase que a correlação dos investimentos do ABC com a quantidade de pastagens degradadas é positiva e fica mais forte quando a APT é mais baixa. Como retratado anteriormente, a variável de APT é a referencia da qualidade das condições edafoclimáticas, portanto, este resultado de correlação confirma que os municípios de predominância do grupo de baixa APT têm melhor aderência da quantidade de crédito concedido e áreas degradadas.

O rebanho bovino apresentou correlação positiva e moderada com os créditos do ABC em todos os grupos de APT. Os municípios de média APT apresentaram maior coeficiente de correlação com o rebanho bovino. Este resultado converge com o maior volume de crédito recebido nesta atividade e grupo de APT, que obtiveram aproximadamente $22 \%$ dos créditos totais do Programa ABC. 
Os municípios de alta APT apresentaram menor correlação entre os empréstimos e o rebanho bovino do que os municípios das demais APT. Quanto às lavouras temporárias e permanentes, os municípios de alta APT registraram maior coeficiente de correlação comparativamente aos demais municípios. Observando que o crédito da atividade agrícola do ABC é predominantemente utilizado em regiões de alta APT, também se percebe através do resultado da correlação convergência com o valor desta produção agrícola. Estes resultados indicam que comparada as atividades, na agricultura a necessidade de recuperação de pastagens e demais características ambientais é relativamente menos importante à adesão do crédito do ABC do que os fatores econômicos.

Tabela 12. Correlação de Spearman por APT e total dos empréstimos do Programa ABC com variáveis selecionadas

\begin{tabular}{|c|c|c|c|c|}
\hline \multirow{2}{*}{ Correlação de Spearman } & \multicolumn{4}{|c|}{ Créditos do Programa ABC } \\
\hline & Apt. A & Apt. B & Apt. CD & Total \\
\hline Pastagem Degradada & $0,3743 * * *$ & $0,4933 * * *$ & $0,5080 * * *$ & $0,4465 * * *$ \\
\hline Rebanho Bovino & $0,4724 * * *$ & $0,5889 * * *$ & $0,5409 * * *$ & $0,5308 * * *$ \\
\hline Rebanho Suíno & $0,2669 * * *$ & $0,2127 * * *$ & 0,0325 & $0,1203 * * *$ \\
\hline Rebanho de Galináceos & 0,0462 & 0,0145 & 0,0099 & $0,0374 *$ \\
\hline Lavouras Temporárias & $0,3628 * * *$ & $0,2427 * * *$ & $0,1966 * * *$ & $0,3025 * * *$ \\
\hline Soja & $0,0960 * *$ & $0,2051 * * *$ & $0,2280 * * *$ & $0,1664 * * *$ \\
\hline Milho & $0,2674 * * *$ & $-0,0199$ & $-0,0220$ & $0,1008 * * *$ \\
\hline Cana-de-açúcar & $0,1364 * * *$ & 0,0479 & 0,0395 & 0,0158 \\
\hline Arroz & $0,1614 * * *$ & $0,2190 * * *$ & $0,1023 * * *$ & $0,1789 * * *$ \\
\hline Feijão & $0,1758 * * *$ & $0,2478 * * *$ & $0,2419 * * *$ & $0,2700 * * *$ \\
\hline Silvicultura & $0,1005^{* *}$ & $-0,0295$ & $-0,0680 * *$ & $-0,0405 * *$ \\
\hline Lavouras Permanentes & $0,1092 * * *$ & $-0,0478$ & $-0,0673 * *$ & 0,0063 \\
\hline Café & $0,1981 * * *$ & $0,1182 * * *$ & $0,1655^{* * *}$ & $0,2108 * * *$ \\
\hline Laranja & $0,1081 * * *$ & $0,0604 *$ & 0,0132 & $0,0351 *$ \\
\hline Dendê & 0,0164 & $-0,0802 * *$ & $-0,0675 * *$ & $-0,0312$ \\
\hline Cacau & 0,0189 & - & 0,0218 & 0,0152 \\
\hline Borracha & $-0,0217$ & $-0,1106 * * *$ & $-0,1279 * * *$ & $-0,0701 * * *$ \\
\hline Extração Vegetal & $0,3132 * * *$ & $0,3250 * * *$ & $0,2355 * * *$ & $0,2069 * * *$ \\
\hline Açaí & $-0,0278$ & 0,0278 & 0,0318 & 0,0124 \\
\hline PIB2013 & $0,3856 * * *$ & $0,2571 * * *$ & $0,1626 * * *$ & $0,2637 * * *$ \\
\hline PIB2014 & $0,3914 * * *$ & $0,2623 * * *$ & $0,1692 * * *$ & $0,2677 * * *$ \\
\hline
\end{tabular}

Fonte: resultados da pesquisa, dados do Instituto Brasileiro de Geografia e Estatística (2006, 2017a; b; c).

*** Ao menos $99 \%$ de significância estatística

** Ao menos $95 \%$ de significância estatística

* Ao menos $90 \%$ de significância estatística 
Ainda que apontado o relevante coeficiente de correlação dos créditos do ABC com o rebanho bovino e pastagens degradadas, é importante mencionar que estas duas últimas variáveis também estão diretamente correlacionadas. No total do Programa ABC o coeficiente de correlação do rebanho bovino com as pastagens degradadas é aproximadamente de 0,74 ao nível de significância de 1\%. No entanto, como observado na Tabela 12, o coeficiente de correlação do rebanho bovino para os empréstimos do Programa ABC é superior ao das pastagens degradadas, ou seja, o tamanho do rebanho bovino é relativamente mais importante que a quantidade de pastagens degradadas.

Além das pastagens degradadas, rebanho bovino, lavouras temporárias e permanentes, outras variáveis obtêm coeficientes de destaque. Cabe ressaltar primeiramente que algumas variáveis específicas quanto às produções agrícolas, mesmo obtendo significância estatística, apresentaram muitos municípios com valores ausentes, o que resulta em mesmo rank nestes municípios, portanto, dificultando o calculo real da correlação destas variáveis. As únicas variáveis que não ultrapassaram $10 \%$ da amostra de municípios com valores ausentes são: pastagens degradadas, rebanho bovino, suíno e de galináceos, lavouras temporárias, milho, lavouras permanentes, PIB 2013 e PIB 2014. Algumas variáveis como o cacau, dendê, borracha e açaí chegaram a obter $80 \%$ ou mais de municípios sem designação dos valores destas produções. O detalhamento dos municípios com valores ausentes de acordo com as variáveis e modelos seria exaustivo, portanto a análise se concentrará na significância estatística.

A relação do PIB municipal com os empréstimos do ABC indica que onde a APT é mais elevada existe maior correlação positiva. Isto pode ocorrer devido ao fato que os municípios de APT mais alta possuem vantagens econômicas, não apenas na produção agropecuária, mas como um todo. Pode-se indagar que quanto maior o PIB dos municípios, maiores as possibilidades de existirem produtores mais capitalizados e de nível técnico para obtenção de empréstimos do ABC.

As correlações do PIB municipal com as pastagens degradadas para o modelo do total dos empréstimos do Programa $\mathrm{ABC}$ foram significativas ao nível de $1 \%$ de confiança, onde registraram impactos fracos, mas positivos, de 0,1260 para o PIB 2013 e 0,1377 para o PIB 2014. Assim, a associação do PIB e empréstimos do ABC é mais forte que a associação do PIB e pastagens degradadas. 
As culturas do açaí, cacau e dendê foram incluídas na análise de correlação devido à criação de linhas especificas no Programa $\mathrm{ABC}$ para o financiamento destas culturas, o $\mathrm{ABC}$ Dendê e o ABC Bioma Amazônia. As produções de açaí e cacau não obtiveram significância estatística em nenhum dos modelos da Tabela 12. Apenas o dendê foi significativo para os municípios de APT “B” e "CD”, no entanto, além de seus impactos serem negativos, são extremamente fracos, aproximando-se de uma associação nula.

Os rebanhos de suínos e galináceos não apresentam resultados estatisticamente significantes para todos os modelos analisados. A baixa associação das atividades, tecnologias e propostas de manejo do ABC para com estes rebanhos pode ser motivo deste resultado. O Tratamento de Dejetos Animais (TDA) seria a linha que mais possibilita a inclusão de rebanhos suínos e galináceos, no entanto, este subprograma representa parcela muito pequena dos investimentos. Os resultados significativos encontrados devem estar associados à concentração produtiva na agropecuária de maneira geral e, não especificamente quanto ao rebanho suíno e galináceos.

Os resultados obtidos na Tabela 13 relacionam as variáveis selecionadas aos empréstimos realizados em cada um dos principais subprogramas (RPD, SPD, FLP e iLPF). 
Tabela 13. Correlação de Spearman do crédito concedido aos principais subprogramas do ABC com variáveis selecionadas

\begin{tabular}{|c|c|c|c|c|}
\hline Correlação de Spearman & RPD & SPD & FLP & iLPF \\
\hline Pastagem Degradada & $0,4571 * * *$ & $0,2766 * * *$ & $0,3054 * * *$ & $0,2827 * * *$ \\
\hline Rebanho Bovino & $0,5862 * * *$ & $0,3012 * * *$ & $0,2787 * * *$ & $0,2966 * * *$ \\
\hline Rebanho Suíno & $0,1767 * * *$ & 0,0058 & $-0,0071$ & $0,1182 * * *$ \\
\hline Rebanho de Galináceos & $0,0430 * *$ & $-0,0522 *$ & $-0,0367$ & 0,0012 \\
\hline Lavouras Temporárias & $0,1986 * * *$ & $0,4069 * * *$ & $0,1164 * * *$ & $0,1638 * * *$ \\
\hline Soja & $0,2304 * * *$ & $0,3064 * * *$ & $0,0573 *$ & $0,1437 * * *$ \\
\hline Milho & $0,1244 * * *$ & $0,2243 * * *$ & 0,0237 & $0,1050 * * *$ \\
\hline Cana-de-açúcar & 0,0025 & $0,0963 * * *$ & $0,1454 * * *$ & 0,0574 \\
\hline Arroz & $0,1969 * * *$ & $0,1511 * * *$ & 0,0403 & 0,0478 \\
\hline Feijão & $-0,0584 * * *$ & $0,1049 * * *$ & 0,0120 & $0,0804 * *$ \\
\hline Silvicultura & $-0,0890 * * *$ & $-0,1230 * * *$ & 0,0452 & $-0,0034$ \\
\hline Lavouras Permanentes & $-0,0471 * *$ & $-0,0452$ & $0,0702 * *$ & $-0,0266$ \\
\hline Café & $-0,0890 * * *$ & $-0,0173$ & 0,0099 & $-0,0428$ \\
\hline Laranja & $-0,1120 * * *$ & $-0,1067 * * *$ & 0,0418 & 0,0033 \\
\hline Dendê & 0,0092 & $-0,0211$ & $-0,0171$ & 0,0596 \\
\hline Cacau & $0,0802 * * *$ & 0,0138 & 0,0050 & 0,0008 \\
\hline Borracha & $0,1752 * * *$ & $0,1359 * * *$ & $0,1352 * * *$ & 0,0257 \\
\hline Extração Vegetal & $0,2577 * * *$ & $0,1474 * * *$ & $0,1441 * * *$ & $0,2509 * * *$ \\
\hline Açaí & $0,0437 * *$ & $-0,0214$ & 0,0049 & 0,0547 \\
\hline PIB2013 & $0,1901 * * *$ & $0,2590 * * *$ & $0,1606^{* * *}$ & $0,1382 * * *$ \\
\hline PIB2014 & $0,1951 * * *$ & $0,2650 * * *$ & $0,1632 * * *$ & $0,1412 * * *$ \\
\hline
\end{tabular}

Fonte: resultados da pesquisa, dados do Instituto Brasileiro de Geografia e Estatística (2006, 2017a; b; c).

*** Ao menos $99 \%$ de significância estatística

** Ao menos $95 \%$ de significância estatística

* Ao menos $90 \%$ de significância estatística

O subprograma de RPD possui correlação moderada e positiva com a quantidade de pastagens degradadas, o coeficiente encontrado foi maior que os dos demais subprogramas. A maior aderência dos créditos em RPD com as pastagens degradadas era esperada, já que esta linha atua diretamente sobre a variável comentada.

Assim como o ocorrido com as pastagens degradadas, a correlação do rebanho bovino com os empréstimos do $\mathrm{ABC}$ foi maior em RPD do que nos demais subprogramas. Quanto aos rebanhos de suínos e de galináceos, a argumentação realizada anteriormente retratando a Tabela 12 pode ser transposta para a Tabela 13. 
As correlações de RPD, rebanho bovino e pastagens degradadas são evidentes. No entanto, dada a ênfase na recuperação ambiental proposta pelo ABC, serie interessante obter maior aderência do crédito às pastagens degradadas em todos os subprogramas. Mesmo que SPD e FLP não possuam caráter reparador de pastagens tão "evidente", em iLPF são diversas as técnicas e estratégias para recuperação do solo aliada a produtividade de culturas temporárias e permanentes.

A correlação positiva da produção de lavouras temporárias e os empréstimos do Programa ABC destacaram-se no Sistema de Plantio Direto (SPD). Nos demais subprogramas a influencia também foi positiva e significante, mas menor do que em SPD. Quanto às lavouras permanentes e silvicultura, a maioria de seus coeficientes não apresentou significância estatística e apenas foram positivos em FLP.

Além do SPD possui maior correlação com as lavouras temporárias, também é mais positivamente relacionada ao PIB dos municípios. Como discutido nas analises do Tabela 12, a associação do crédito agrícola aos municípios de APT mais elevada, pode influenciar nesta correlação. Estes municípios de alta APT estão localizados mais próximos às regiões mais produtivas e de maior desenvolvimento econômico, no Sudeste e Sul.

Das culturas de açaí, cacau e dendê apenas as duas primeiras obtiveram resultados estatisticamente significativos e somente no subprograma de RPD, porém o coeficiente de correlação encontrado foi extremamente fraco. Estas considerações reforçam os argumentos anteriormente apresentados sobre a baixa representatividade destas culturas para o Plano ABC.

Através da análise de correlação sintetizaram-se os resultados encontrados sobre a alocação e execução dos recursos do $A B C$ nas seções 4.1 e 4.2, além de complementa-los. É possível dividir as considerações realizadas em dois pontos principais em que existem deficiências: a distribuição de recursos entre as linhas de financiamento do Programa ABC e a alocação regional.

A constatação da contratação efetiva de apenas quatro do total de dez linhas do Programa ABC é uma deficiência que precisa ser explorada. Em alguns casos, como em fixação biológica de nitrogênio, pode não haver necessidade de contratação de crédito apenas para implementação desta atividade. Outras linhas beneficiam culturas que apresentam baixa produção e presença no território nacional. Em cada linha e região pode-se realizar um levantamento de grande número 
de entraves na contratação do $\mathrm{ABC}$, assim como ressaltado em estudos de caso citados neste trabalho.

Destaca-se que o ABC Orgânico, ABC Dendê e ABC Bioma Amazônia são exemplos de subprogramas que contemplam aspectos muito específicos de culturas pouco abrangentes no território nacional. Estes não foram previstos no Plano $\mathrm{ABC}$, $\log$, não se obtém clareza se as propostas originais do Plano ABC não atenderiam as necessidades das culturas beneficiadas por tais subprogramas.

Uma possibilidade para contornar esta concentração entre os subprogramas consiste em extinguir as divisões por subprograma das linhas de empréstimo do Programa ABC. Por mais que se mantenham as metas e sistemas de manejo propostos, a contratação de uma vertente do ABC não deveria ser impeditiva a contratação de outras. Ao implementar um sistema de iLPF o produtor pode aderir ao sistema de plantio direto para a lavoura, incorporando o tratamento das culturas para a fixação biológica de nitrogênio, realizando a implementação de gêneros florestais e valendo-se deste processo para recuperar as pastagens degradadas. O exemplo apresentado inclui RPD, SPD, iLPF, FLP e FBN em apenas um sistema produtivo, havendo possibilidade de representar ainda mais linhas de financiamento, caso utilize culturas orgânicas, dendê, açaí ou demais culturas beneficiadas pelo ABC Orgânico, ABC Dendê e ABC Bioma Amazônia. Em um caso como no exemplo citado, as divisões delimitadas das linhas do Programa perdem o sentido.

Caso unificadas as linhas de empréstimos do Programa $\mathrm{ABC}$, o critério de área de implementação nem sempre será a característica mais adequada para mensurar a efetividade do ABC. Outras metodologias para o calculo efetivo de mitigação de emissões de GEE também poderiam ser incluídas, baseando-se em coeficientes técnicos de mitigação provenientes da implementação destas atividades.

O segundo ponto diz respeito à ineficiência da alocação dos recursos entre as regiões brasileiras. Os dados demonstram que as regiões que deveriam ser prioritárias recebem baixo volume de recursos. Além disto, existem deficiências na aplicação dos recursos de acordo com a APT, variável proxy do cenário de degradação e/ou baixa produtividade dos municípios.

Diante das considerações consolidadas na literatura da necessidade de investimentos no Norte, Nordeste e até mesmo no Centro-Oeste, a variável de aptidão agrícola pode ser utilizada para caracterização mais específica das características ambientais das áreas de aplicação dos investimentos do $\mathrm{ABC}$. Esta mensuração pode ser realizada pela delimitação da área de 
implementação dos investimentos no ABC e conferência da propriedade através da base de dados de APT. A ferramenta para tal avaliação existe, o Cadastro Ambiental Rural (CAR) inclui a delimitação da área da propriedade por meio de imagens de satélite, o que poderia ser usado para análise. Outros métodos também podem ser considerados, como exigências de análise de qualidade dos solos e características climáticas e de relevo.

As sugestões expostas indicam a necessidade de criação de um sistema que elenque as áreas prioritárias para implementação do Programa ABC. Este sistema gerará possibilidades para a diferenciação de benefícios e subsídios de acordo com as reais necessidades da área de aplicação dos investimentos do Programa, o que poderá resultar em uma distribuição mais eficiente dos recursos.

Estas sugestões não abrangem todas as possíveis melhorias para a alocação e execução de recursos do Plano e Programa $\mathrm{ABC}$, até mesmo por não tratarem de questões levantadas na literatura como a burocracia e insuficiência de assistência técnica, deficiências estas que também devem ser estudadas para encontrar alternativas aos procedimentos que são realizados atualmente. Como abordado durante o texto, as características regionais do território nacional são diversas, com riscos, logísticas, regimes climáticos, conhecimento técnico e variáveis econômicas muito distintas. Estas características influenciam diretamente na aplicabilidade do Plano e Programa ABC, logo, estas sugestões são breves exemplos de ações que podem ser generalizadas em todo o território nacional, com verificação dos meios para realização e aplicabilidade a serem aprofundados pelos executores do $\mathrm{ABC}$.

\subsection{Especificidades Adicionais do Perfil Agropecuário e das Modalidades}

Utilizando a "Base 1" pode-se realizar a classificação dos subprogramas de acordo com a APT e o perfil agropecuário. De antemão destaca-se a concentração do volume de crédito concedido, da área de abrangência e quantidade de contratos do Programa $\mathrm{ABC}$ em municípios de predominância de grandes produtores. Parte desta concentração se deve à caracterização de cerca de $50 \%$ dos municípios brasileiros nesta classificação. Como existe este padrão a apresentação das informações desagregadas por regiões foi dispensada, encontrando-se nas Tabelas 24, 25 e 26 do Anexo III. 
Nos municípios caracterizados como de alta APT, em todos os principais subprogramas e critérios os municípios de predominância de grandes produtores corresponderam a 91,3\% ou mais do realizado, com média de 95,4\%. Nos municípios de média APT os quatro subprogramas mais relevantes tem participações iguais ou superiores a $83,3 \%$ e média de $88,7 \%$ de grandes produtores. No grupo de baixa APT o menor valor percentual dos grandes produtores nos subprogramas mais representativos foi de 59,7\%, frente à média de 76,1\% nos mesmos subprogramas.

Na Tabela 14 verifica-se o abordado a cerca da dominância do perfil de grandes produtores na distribuição de crédito do Programa ABC. Do montante total, apenas 8,1\% são provenientes de produtores familiares e aproximadamente $6 \%$ dos produtores médios, enquanto os grandes correspondem a $85,9 \%$.

Esta relação de predominância do perfil de grandes produtores poderia ser averiguada com mais cautela caso existissem disponíveis as informações dos produtores rurais que tomaram os empréstimos ao invés da classificação geral do município. A generalização por predominância no município é um método que possibilita apenas uma aproximação ao resultado real.

Tabela 14. Participação no crédito concedido total por subprogramas, perfil agropecuário e APT, em relação ao total de crédito concedido no Brasil. Em porcentagem (\%)

\begin{tabular}{|c|c|c|c|c|c|c|c|c|c|c|c|c|c|}
\hline \multirow{2}{*}{ Subprog. } & Apt. A & Apt. B & Apt. CD & \multirow{2}{*}{$\mathbf{F}$} & \multirow{2}{*}{\begin{tabular}{|c|} 
Apt. A \\
$\mathbf{M}$ \\
\end{tabular}} & \multirow{2}{*}{$\begin{array}{c}\text { Apt. B } \\
\mathbf{M}\end{array}$} & \multirow{2}{*}{$\frac{\text { Apt. CD }}{\mathbf{M}}$} & \multirow{2}{*}{$\mathbf{M}$} & \multirow{2}{*}{\begin{tabular}{|c|} 
Apt. A \\
G
\end{tabular}} & \multirow{2}{*}{\begin{tabular}{|c|} 
Apt. B \\
G \\
\end{tabular}} & \multirow{2}{*}{\begin{tabular}{|c|} 
Apt. CD \\
G \\
\end{tabular}} & \multirow{2}{*}{ G } & \multirow{2}{*}{ TOTAI } \\
\hline & $\mathbf{F}$ & $\mathbf{F}$ & $\mathbf{F}$ & & & & & & & & & & \\
\hline RPD & 0,3 & 1,9 & 2,9 & 5,1 & 0,5 & 1,1 & 2,1 & 3,7 & 11,1 & 19,2 & 12,8 & 43,1 & 51,9 \\
\hline SPD & 0,0 & 0,3 & 0,5 & 0,8 & 0,3 & 0,4 & 0,3 & 1,1 & 10,9 & 7,5 & 5,3 & 23,8 & 25,7 \\
\hline iLPF & 0,0 & 0,3 & 0,4 & 0,7 & 0,1 & 0,1 & 0,2 & 0,3 & 2,0 & 2,6 & 1,9 & 6,5 & 7,5 \\
\hline FLP & 0,1 & 0,2 & 1,0 & 1,3 & 0,1 & 0,2 & 0,5 & 0,8 & 3,7 & 3,5 & 3,9 & 11,2 & 13,3 \\
\hline ARA & 0,0 & 0,0 & 0,0 & 0,0 & 0,0 & 0,0 & 0,0 & 0,0 & 0,0 & 0,1 & 0,0 & 0,1 & 0,1 \\
\hline TDA & 0,0 & 0,0 & 0,0 & 0,0 & 0,0 & 0,0 & 0,0 & 0,0 & 0,1 & 0,0 & 0,2 & 0,2 & 0,3 \\
\hline OUT & 0,0 & 0,1 & 0,0 & 0,1 & 0,0 & 0,1 & 0,0 & 0,1 & 0,2 & 0,3 & 0,5 & 1,0 & 1,2 \\
\hline BRASIL & 0,4 & 2,8 & 4,9 & 8,1 & 0,9 & 1,9 & 3,1 & 6,0 & 28,0 & 33,3 & 24,7 & 85,9 & 100,0 \\
\hline
\end{tabular}

Fonte: resultados da pesquisa, dados do Instituto Brasileiro de Geografia e Estatística (2006).

O Plano ABC não prevê, nem delimita, que as atividades implementadas gerem também melhor distribuição de renda, ou reforma fundiária. Tendo em vista que não é explícito caráter social no Plano e Programa ABC, o destino de recursos aos grandes produtores pode estar em consonância com o nível de capitalização e acesso ao crédito, bem como a capacitação técnica 
para adaptarem-se as inovações propostas. Os grandes produtores também podem obter maior propensão a adotar as propostas em virtude da degradação das áreas e pastagens derivadas da monocultura e da exploração de pastagens extensivas. Esta consideração não descarta que a realização de investimentos para o incremento de eficiência agropecuária e ambiental do Brasil pudesse ser realizada em conjunto com discussões sobre reforma fundiária. Esta discussão desvia-se do escopo deste trabalho, que se delimita a analisar e verificar os impactos ambientais da alocação e execução de recursos observados.

As informações que serão apresentadas a seguir representam as participações das modalidades $^{21}$ de Aquisição de Animais (AA), Aquisição de Animais de Serviço (AAS), Aquisição de Veículos (AV), Formação de Culturas Perenes (FCP), Máquinas e Equipamentos (MEQ), Melhoramento de Explorações (MEX) e Outras Modalidades (OM), nos créditos e observações, intrarregionais e totais, logo, utilizam os dados disponíveis na "Base 2".

As classificações de "melhoramento de explorações" e "outras modalidades" são muito amplas e genéricas para possibilitar análise. O reduzido número de modalidades contempladas na base dificulta a identificação da real aplicabilidade dos recursos. A adição de sistema mais específico na composição das modalidades auxiliaria futuras análises a respeito do Plano e Programa ABC.

Apesar do limitado detalhamento oferecido por estas informações, os dados demonstrados permitem analisar alguns estados que possuem comportamentos divergentes da média brasileira, bem como verificar a participação de cada região nos investimentos realizados por subprograma.

A modalidade de "aquisição de animais" representa média de 17,8\% do crédito de RPD. Esta participação indica que na média o limite do crédito de custeio para compra de animais é respeitado. A aquisição de animais pode parecer alheia aos objetivos de mitigação de emissões de GEE, no entanto, para viabilizar a produção pecuária em pastagens recuperadas é necessário fornecer condições ao produtor de inserir animais nestas pastagens. É plausível a realização de pesquisas para verificar a proporção de capital necessário para recuperar o hectare de pastagem e o custo da compra do animal, como meio de verificação se não há a utilização excessiva do crédito do ABC para compra de animais.

Ao comparar as aquisições de animais de RPD às de iLPF, observou-se uma participação média desta modalidade em iLPF de aproximadamente 4,1\%, bem menor que em RPD. Existem

21 Informações completas disponíveis no Anexo AIV, Tabelas 35, 36, 37 e 38. 
varias possibilidades para explicar este fenômeno: as atividades de integração podem estar sendo viabilizadas em maior quantidade para o estabelecimento de lavouras e florestas; os produtores rurais podem usar o plantel já estabelecido na propriedade para compor o sistema de integração; ou os custos de implantação de florestas e culturas agrícolas sobrepõe-se ao da compra de animais. Estas observações não excluem as possibilidades de outros fenômenos para explicar a alocação de recursos em iLPF.

Algumas participações da modalidade de Formação de Culturas Perenes (FCP) foram significativas nos subprogramas de RPD e SPD, principalmente no Sudeste. É possível questionar se o credito obtido nessas linhas está de alguma maneira sendo utilizado também para o estabelecimento de atividades de integração (iLPF) ao invés de apenas "recuperação de pastagens" e "plantio direto". Mesmo que representem parcelas relativamente pequenas dos créditos concedidos, esta modalidade parece pouco justificável nos subprogramas citados.

Destaca-se no detalhamento dos subprogramas a baixa composição de investimentos em “máquinas e equipamentos". Implementos agrícolas como tratores, plantadeiras e colheitadeiras possuem preços elevados, mas são essenciais para as culturas agrícolas, florestais e também para o processo de recuperação de pastagens. A baixa concessão de crédito neste sentido é difícil de ser contextualizada sem uma análise mais específica das demais linhas de crédito disponíveis e do conhecimento da existência prévia ou não destes equipamentos nas propriedades rurais. 


\section{CONSIDERAÇÕES FINAIS}

Os programas $\mathrm{ABC}$ Recuperação (RPD), Plantio Direto (SPD), Integração (iLPF) e Florestas (FLP) absorveram parcela superior a 98\% dos recursos disponibilizados. O principal subprograma consiste na recuperação de pastagens degradadas, responsável por montante superior a $50 \%$ do exercido pelo $\mathrm{ABC}$. A concentração de recursos em quatro subprogramas conduz a crítica da formulação do Plano, onde elevada parcela das técnicas sugeridas não estão sendo adotadas, indicando a necessidade de reavaliação das inovações propostas e de realização de estudos técnicos-científicos.

As linhas de financiamento $\mathrm{ABC}$ Orgânico, Ambiental (ARA), Tratamento de Dejetos (TDA), Dendê, Fixação (FBN) e Bioma Amazônia representam menos de 2\% do crédito total aplicado pelo Programa. Acredita-se que a baixa representatividade no território e na produção nacional das culturas específicas beneficiadas pelo $\mathrm{ABC}$ Orgânico, Dendê e Bioma Amazônia influencie na diminuta adesão destas linhas de crédito. A viabilidade econômica dos projetos é um dos fatores apontados na literatura sobre o Plano ABC para a insuficiência na aquisição de recursos. A possibilidade de adotar diversas tecnologias propostas utilizando os recursos de uma única linha de crédito do Programa, como a implementação da fixação biológica de nitrogênio através da aquisição de empréstimos para o sistema de plantio direto, também podem resultar em distorções nos resultados encontrados.

A concentração regional dos recursos ocorreu no Centro-Oeste e Sudeste, a primeira região com predominância em volume de empréstimos e de área de implementação e a segunda com maiores participações em quantidade de contratos. O Centro-Oeste possui elevada produtividade agropecuária em algumas regiões, mas também possui vasta área degradada para implementação de investimentos do ABC. A baixa participação do Norte e Nordeste continua a se apresentar como entrave aos objetivos de aumentar a eficiência da agropecuária nacional e reduzir emissões de GEE.

Ao introduzir a APT na análise da distribuição dos recursos amplia-se a disparidade da alocação dos mesmos e da proposta de mitigação de emissões de GEE. Observou-se que a maioria do crédito do $\mathrm{ABC}$ está concentrada em municípios de predominância de alta e média APT, locais onde a produção agropecuária está mais bem estabelecida e desenvolvida. Nas regiões de maior APT, mesmo que os investimentos do ABC contribuam para os aspectos 
ambientais, possuem menos impacto do que se utilizados em locais de baixa APT. A existência de grande volume de investimentos em regiões de APT elevada é o mais preocupante aos objetivos do Programa, inclusive no Nordeste, ao mesmo tempo em que existe vasto território de baixa produtividade para ser beneficiado. Percentualmente as regiões que mais possuíram investimentos em áreas de baixa APT foram Nordeste, Norte e Sul, no entanto, mesmo nestas regiões existe elevado coeficiente aplicado em regiões de média e alta APT e, sobretudo, estas regiões correspondem à pequena parcela dos recursos totais disponibilizados pelo Programa.

Verificou-se que os valores médios de contratos e por hectare não apresentam nenhum padrão de distribuição, principalmente ao adicionar as divisões entre as APT dos municípios. Mesmo que não explicitado no Plano $\mathrm{ABC}$, a aquisição de maiores valores médios por contrato e hectare seriam esperados nas regiões prioritárias para a mitigação de GEE e municípios de predominância de baixa APT, no entanto, isto não foi observado.

Existem dificuldades quanto ao critério de área de implementação dos projetos do $\mathrm{ABC}$ devido a atual especificação desta variável na base de dados, inclusive com elevado coeficiente de contratos sem a delimitação da área. A utilização de apontamento no Cadastro Ambiental Rural (CAR) da área abrangida pelos contratos realizados poderia auxiliar futuras avaliações.

Observou-se que a magnitude de correlação dos empréstimos com o rebanho bovino é maior do que com as pastagens degradadas. Também ficou claro que quanto maior a APT, mais elevada a correlação dos empréstimos com a produção de lavouras temporárias e com o PIB municipal. Estes indicadores indicam que as variáveis econômicas da produção agropecuária podem possuir maior relevância para a contratação do Programa ABC do que a existência de áreas de baixa produtividade ou em estado de degradação.

Quanto aos subprogramas, em RPD houve maior correlação dos empréstimos com as pastagens degradadas e ao rebanho bovino. Em SPD ocorreu menor importância das pastagens degradadas e ampliação da correlação com a produção de lavouras temporárias e com o PIB municipal. Em geral os empréstimos voltados à atividade da pecuária possuem melhor atribuição de acordo com a degradação local, comparativamente à agricultura.

Como se pode verificar, os resultados do Programa ABC têm sido muito heterogêneos em termos da sua implementação quando comparados com os objetivos originais. Aparentemente, as dificuldades envolvidas nos subprogramas de FBN, TDA e ARA, têm limitado a adesão destas tecnologias a patamares extremamente baixos, onde em alguns cenários apresentam ausência 
completa. O cumprimento dos objetivos quanto a estas propostas distancia-se do observado na execução dos recursos. Como reavaliação do Plano e Programa ABC, o caráter não exclusivo das linhas de financiamento poderia auxiliar a ampliação da contratação dos empréstimos.

A alocação dos recursos perante as características edafoclimáticas também vêm apresentando elevada heterogeneidade, se analisada conjuntamente as propostas originais do Plano ABC. As dificuldades com a implementação das tecnologias ocorrem, sobretudo nas regiões em que os recursos deveriam ser aplicados, ou seja, nos locais de maior ineficiência agropecuária como no Norte e Nordeste brasileiro. Critérios para definir as regiões prioritárias para os investimentos do ABC de acordo com o cenário de degradação devem ser criados. Para alcançar tal detalhamento, variáveis como a APT utilizada neste trabalho e de mecanismos como o Cadastro Ambiental Rural podem ser utilizados para gerar informações que permitam conceder recursos em condições diferenciadas de acordo com os impactos ambientais positivos gerados.

Existem algumas limitações quanto as variáveis utilizadas neste trabalho. A APT e o perfil agropecuário possuem restrições quanto à precisão dos grupos encontrados, devido a necessidade de utilizar a predominância no município para caracterizar estes grupos. Caso houvesse georreferenciamento das informações do Programa ABC, maior precisão poderia ser concedida para tais variáveis. No caso do perfil agropecuário, um novo Censo, com informações atualizadas e detalhadas seria necessário para incrementar as possibilidades de analises. A disponibilidade de um novo Censo também possibilitaria a atualização da variável de "pastagens degradadas" na análise de correlação.

Finalmente, além das possibilidades de incrementar este trabalho através de melhorias na base de dados, podem ser realizadas novas pesquisas, estabelecendo regiões, estados e até mesmo municípios específicos, de modo a proporcionar uma revisão do Programa ABC de forma mais precisa as necessidades destes locais, facilitando a caracterização de deficiências e oportunidades do ABC. 


\section{REFERÊNCIAS}

AIDAR, H.; KLUTHCOUSKI, J. Evolução das atividades lavoureira e pecuária nos Cerrados. In: AIDAR, H.; KLUTHCOUSKI, J.; STONE, L. F. (Eds.). . Integração Lavoura-Pecuária. Santo Antônio de Goiás: Embrapa Arroz e Feijão, 2003. p. 25-58.

AQUINO, G. et al. O Uso De Biogas No Ambito Rural Como Proposta De Desenvolvimento Sustentavel. Revista Cientifica da Faculdade de Educação e Meio Ambiente, v. 5, n. 1, p. 140-149, 2014.

ASSAD, E. D. et al. Climatic changes impact in agroclimatic zonning of coffee in Brazil. Pesquisa Agropecuaria Brasileira, v. 39, n. 11, p. 1057-1064, 2004.

- Agricultura de Baixa Emissão de Carbono: A evolução de um novo paradigma Eduardo de Morais Pavão. Observatório ABC, p. 38, 2015.

BALBINO, L. C. et al. Evolução tecnológica e arranjos produtivos de sistemas de integração lavoura-pecuáriafloresta no Brasil. Pesquisa Agropecuaria Brasileira, v. 46, n. 10, p. 1-12, 2011.

BANCO CENTRAL BRASILEIRO. Crédito Rural: Programa para Redução da Emissão de Gases de Efeito Estufa na Agricultura (Programa ABC)Brasília, 2016.

BARROS, A. M. DE. Avaliação do uso estratégico das áreas prioritárias do Programa ABC. [s.l.] Observatório $\mathrm{ABC}, 2017$.

BRASIL. Meio Ambiente: acordos globais. Disponível em: <http://www.brasil.gov.br/meioambiente/2012/01/acordos-globais>. Acesso em: 4 fev. 2017.

\section{Pretendida Contribuição Nacionalmente Determinada. Disponível em:} <http://www.itamaraty.gov.br/images/ed_desenvsust/BRASIL-iNDC-portugues.pdf>. Acesso em: 17 jul. 2017.

CARVALHO, A. L. DE et al. Impact of climate changes on potential sugarcane yield in Pernambuco, northeastern region of Brazil. Renewable Energy, v. 78, n. July, p. 26-34, 2015.

CHEN, P. Y.; POPOVICH, P. M. Correlation: Parametric and Nonparametric Measures. [s.1.] Sage University Papers Series on Quantitative Applications in the Social Sciences, 2002.

COMISSÃO MUNDIAL SOBRE MEIO AMBIENTE E DESENVOLVIMENTO. Nosso Futuro Comum. 2. ed. Rio de Janeiro: Fundação Getúlio Vargas, 1991.

DIAS FILHO, M. B. Diagnóstico das Pastagens no Brasil. Embrapa Amazônia Oriental, v. Documentos, p. 22, 2014.

EMBRAPA. Marco referencial Integração Lavoura-Pecuária-Floresta. [s.l: s.n.].

_. Fixação biológica de nitrogênio: sobre o tema. Disponível em: <https://www.embrapa.br/tema-fixacaobiologica-de-nitrogenio/nota-tecnica>. Acesso em: 15 set. 2017.

FAVARATO, L. F. et al. Atributos Químicos Do Solo Com Diferentes Plantas De Cobertura Em Sistema De Plantio Direto Orgânico. Revista Brasileira de Agropecuária Sustentável, v. 5, n. 2, p. 19-28, 2015.

FOlETO, E. M.; LEITE, M. B. Perspectivas Do Pagamento Por Serviços Ambientais E Exemplos De Caso No Brasil. Revista de estudos ambientais, v. 13, n. 1, p. 6-17, 2011. 
FOOD AND AGRICULTURE ORGANIZATION OF UNITED NATIONS. FAO Statistical Pocketbook 2015: World food and agriculture. [s.l: s.n.].

HUNGRIA, M.; CARVALHO MENDES, I.; MARTINS MERCANTE, F. A fixação biológica do nitrogênio como tecnologia de baixa emissão de carbono para as culturas do feijoeiro e da soja, 2013. Disponível em: <http://ainfo.cnptia.embrapa.br/digital/bitstream/item/103488/1/ID-34572-1.pdf>

INSTITUTO BRASILEIRO DE GEOGRAFIA E ESTATÍSTICA. Censo Agropecuário 2006. Disponível em: <http://www.ibge.gov.br/home/estatistica/economia/agropecuaria/censoagro/2006>. Acesso em: 5 maio. 2017.

Produção Agrícola Municipal. Disponível em: 〈https://sidra.ibge.gov.br/pesquisa/pam/tabelas〉. Acesso em: 5 maio. 2017a.

_. Produção da Extração Vegetal e da Silvicultura. Disponível em: <https://sidra.ibge.gov.br/pesquisa/pevs/tabelas/brasil/2015>. Acesso em: 5 maio. 2017 b.

__. Pesquisa Pecuária Municipal. Disponível em: 〈https://sidra.ibge.gov.br/pesquisa/ppm/tabelas/brasil/2015>. Acesso em: 5 maio. 2017c.

INTERGOVERNMENTAL PANEL ON CLIMATE CHANGE. Summary for Policymakers. Geneva: [s.n.].

KICHEL, A. N. et al. Sistema de integração lavoura-pecuária-floresta (ILPP) - Experiencia no Brasil. Boletim de Indústria Animal, v. 71, n. 1, p. 94-105, 2014.

LARCHER, T. P. A. DE O. Construção de um modelo lógico do Plano ABC (Agricultura de Baixa Emissão de Carbono) como uma proposta de avaliação. [s.1.] Universidade de Brasilia, 2016.

LEAL, B. P. PROGRAMA ABC:UMA ANÁLISE PARA O PERÍODO DE 2011 A 2014. [s.1.] Fundação Getúlio Vargas, 2016.

LOPES, É. C. P.; MORAES, A. DE; LANG, C. R. Estudo do fracionamento isotópico de nitrogênio aplicado à gramíneas e leguminosas forrageiras. Brazilian Journal of Applied Technology for Agricultural Science, v. 9, n. 1, p. 121-130, 2016.

MACEDO, M. C. M. Integração lavoura e pecuária: o estado da arte e inovações tecnológicas. Revista Brasileira de Zootecnia, v. 38, n. SUPPL. 1, p. 133-146, 2009.

MARENGO, J. A. Mudanças climáticas globais e seus efeitos sobre a biodiversidade: caracterização do clima atual e definição das alterações climáticas para o território brasileiro ao longo do século XXI. Brasília: Ministério do Meio Ambiente, 2006.

MARGULIS, S. A Regulamentação Ambiental: Instrumentos e Implementação. Brasília: Instituto de PEsquisa Econômica Aplicada, 1996.

MINISTÉRIO DA AGRICULTURA PECUÁRIA E ABASTECIMENTO. Plano Setorial de Mitigação e Adaptação às Mudanças Climáticas para Consolidação da Economia de Baixa Emissão de Carbono na Agricultura - PLANO ABC. Brasília: [s.n.].

MINISTÉRIO DO MEIO AMBIENTE. Protocolo de Quioto. Disponível em: <http://www.mma.gov.br/clima/convencao-das-nacoes-unidas/protocolo-de-quioto>. Acesso em: 11 abr. 2017. 
OBSERVATÓRIO ABC. Agricultura de Baixa Emissão de Carbono: Financiando a transição. Disponível em: $<$ https://s3-sa-east-

1.amazonaws.com/arquivos.gvces.com.br/arquivos_gvces/arquivos/263/financiandoatransicao_planoabc.pdf>. Acesso em: 13 jan. 2017.

_. Análise dos Recursos do Programa ABC Safra 2013 / 2014 ( até abril ). Disponível em: <http://gvces.com.br/arquivos/289/ABC_DO_CLIMA_VOL._4_EM_SIMPLES.pdf〉. Acesso em: 13 jan. $2017 \mathrm{a}$.

—. Análise dos Recursos do Programa ABC - Visão Regional. Disponível em: <https://s3-sa-east1.amazonaws.com/arquivos.gvces.com.br/arquivos_gvces/arquivos/339/ObsABC_Relatorio2_AnaliseRecursosR egional_ResEx.pdf>. Acesso em: 13 jan. 2017b.

_. Análise dos Recursos do Programa ABC - Finalidade de investimentos. Disponível em: $\langle$ http://mediadrawer.gvces.com.br/abc/original/em-baixa_em-simples.pdf〉. Acesso em: 13 jan. 2017c.

_. Análise dos Recursos do Programa ABC - Foco na Amazônia Legal - potencial de redução de GEE e estudo de caso sobre o Programa ABC em Paragominas. Disponível em: <http://observatorioabc.com.br/wpcontent/uploads/2016/10/Relatorio-Completo_Análise-dos-Recursos-ABC-safra1516.pdf >. Acesso em: 13 jan. 2017a.

. Propostas para Revisão do Plano ABC. Disponível em: <http://hdl.handle.net/10438/15314>. Acesso em: 13 jan. 2017b.

. Análise dos Recursos do Programa ABC - Instituições financeiras privadas - Safra 2015/16. Disponível em: <http://observatorioabc.com.br/wp-content/uploads/2016/10/Sumario_ABC_Primeiro_FinalComFotos.pdf>. Acesso em: 13 jan. 2017.

. Análise dos Recursos do Programa ABC Safra 2016 / 17 Observatório do Plano ABC ( Contribuição para a NDC e Capacita ABC ). p. 1-36, 2017a.

. Impactos econômicos e ambientais do Plano ABC. p. 1-28, 2017b.

Desafios e restrições dos produtores rurais na adoção de tecnologias de baixo carbono ABC: Estudo de caso em Alta Floresta, em Mato Grosso. Disponível em: <http://observatorioabc.com.br/wpcontent/uploads/2017/05/Relatorio-Completo_AltaFloresta-.pdf>. Acesso em: 13 jan. 2017c.

OBSERVATÓRIO DO CLIMA. Análise da evolução das emissões de GEE no Brasil (1990-2002): documento síntese. São Paulo: [s.n.]. Disponível em: <http://dialogochino.net/wpcontent/uploads/2015/07/SEEG_DocumentoSintese.pdf>.

OLIVEIRA, M. O. Declínio populacional das abelhas polinizadoras de culturas agrícolas. ACTA Apicola Brasilica, v. 3, n. 2, p. 01-06, 2015.

ORGANIZAÇÃO DAS NAÇÕES UNIDAS. Conferência das Nações Unidas sobre Mudança Climática: COP21/CMP11. Disponível em: <https://nacoesunidas.org/cop21>. Acesso em: 7 abr. 2017.

PAIXÃO, M. A. S. DA; BACHA, C. J. C. A agropecuária brasileira e a sua inserção na Economia Verde : uma análise do Plano e do Programa ABC. Pesquisa \& Debate, v. 26, n. 47, p. 75-98, 2015.

PElleGRINO, G. Q.; ASSAD, E. D.; MARIN, F. R. Mudanças Climáticas Globais e a Agricultura no Brasil. Revista Multiciência, n. 8, p. 139-162, 2007. 
RIVERO, S. et al. Pecuária e desmatamento: Uma análise das principais causas diretas do desmatamento na Amazônia. Nova Economia, v. 19, n. 1, p. 41-66, 2009.

SPAROVEK, G. (ED.). Avaliação da implementação do Plano Setorial de Mitigação e de Adaptação às Mudanças Climáticas para a Consolidação de uma Economia de Baixa Emissão de Carbono na Agricultura - PLANO ABC. Piracicaba: IICA/BRA/02/2015, 2015.

STABILE, M. C. C.; AZEVEDO, A.; NEPSTAD, D. O Programa “Agricultura de Baixo Carbono" do Brasil: barreiras para sua implementação. p. 1-6, 2012.

TRIPOLI, R. Relatório RIO + 20. Disponível em:

<http://www.camara.gov.br/proposicoesWeb/prop_mostrarintegra?codteor=1081500\&filename=REL+1/2013+

CMADS>. Acesso em: 20 jul. 2017.

TUFFANI, M. Dez anos depois, Protocolo de Kyoto falhou em reduzir emissões mundiais. Folha de São Paulo, 16 fev. 2015.

WANDER, A. E.; TOMAZ, G. A.; PINTO, H. E. Uma avaliação formativa do Plano ABC. Revista de Política Agrícola, v. 25, n. 3, p. 62-72, 2016.

ZIMMER, A. H. et al. Degradação, recuperação e renovação de pastagens. Embrapa Gado de Corte, p. $42,2012$. 


\begin{abstract}
ANEXOS
ANEXO A. Processamento do Modelo de Aptidão Agrícola ${ }^{22}$

O modelo desenvolvido analisa o meio físico a partir das características de solos, clima e topografia, dividindo-se, portanto em três partes, denominadas dimensões. Cada uma das dimensões é alimentada com informações básicas obtidas em base de dados secundárias, predominantemente públicas e disponíveis para download, que são interpretadas sob o ponto de vista agronômico e processadas através de ferramentas computacionais (banco de dados, SIG) a fim de gerar índices de qualidade do meio físico. Os resultados obtidos de cada uma das dimensões são então integrados através de operações lógicas e matemáticas em ambiente de Sistemas de Informações Geográficas, gerando duas matrizes contendo classes de aptidão para culturas agrícolas anuais com resolução espacial de $30 \mathrm{~m}$ x $30 \mathrm{~m}$ e abrangendo todo o território brasileiro.
\end{abstract}

\title{
Solos
}

Os solos são interpretados no modelo como um meio de crescimento de plantas, ou seja, as múltiplas informações pedológicas contidas na legenda do mapa e nas análises químicas e físicas são sintetizadas e hierarquizadas segundo a capacidade de prover condições de desenvolvimento vegetal. Nesse sentido, através da interpretação da legenda do mapa de solos e aplicação de chaves lógicas no banco de dados é possível espacializar e integrar as informações e mapa básico em 3 índices de manejo ou qualidade pedológica e em um índice médio: DS (drenagem), FS (fertilidade), CE (condições de enraizamento) e IMS (índice médio). Quanto maior o valor do índice maior é a disponibilidade do fator relacionado. Por exemplo, um solo com índice de fertilidade de valor nove tem melhores condições de suprir as plantas de nutrientes do que um com nota cinco, sendo tal raciocínio válido também para os outros fatores.

22 Este anexo foi extraído de Sparovek (2015) retratando a construção da variável de Aptidão Agrícola. 


\section{Clima}

O clima de uma região é representado por um conjunto de características atmosféricas denominadas de elementos do clima. Esses elementos são medidos em postos meteorológicos, sendo que os mais comumente medidos são a temperatura do ar à sombra $\left({ }^{\circ} \mathrm{C}\right)$ e a precipitação pluviométrica $(\mathrm{mm})$. Neste modelo, a forma como os elementos do clima se combinam no espaço e no tempo são interpretadas segundo o potencial para desenvolvimento vegetal no sentido de gerar classes de aptidão para culturas agrícolas no Brasil.

Em função da múltipla origem das bases de dados climáticas, são aplicadas ferramentas matemáticas e de banco de dados (regressões lineares, filtros, remoção de duplicatas e remoção de dados inconsistentes) para gerar um banco georreferenciado unificado com 3.545 estações meteorológicas cobrindo o território Brasileiro (para detalhes ver ANEXO II).

Ao final desse processo os dados ainda passam por uma rotina computacional desenvolvida especificamente para cálculo do balanço hídrico e índices de qualidade climática utilizados na modelagem como variáveis climáticas, gerando índices integradores e classes de aptidão climática.

\section{Topografia}

A aptidão da topografia para culturas agrícolas é avaliada no modelo preliminar segundo a viabilidade para mecanização. Considera-se que quanto menor é a viabilidade de mecanização menor é a aptidão para exploração agrícola. A base para as análises relacionadas à topografia é um Modelo Digital de Elevação (ou DEM), que consiste numa matriz na qual é representada a altitude em relação ao nível médio do mar cobrindo toda a área do Brasil. A partir dessa matriz é calculada a declividade do terreno que, então, é classificada segundo o potencial de mecanização para agricultura.

\section{Integração}

As informações de solos, clima e topografia são integradas em uma última etapa a fim de gerar as matrizes de classes de aptidão. Esse processo é baseado em ferramentas de operação de matrizes georreferenciadas, ou seja, as informações de cada tema são superpostas e cruzadas através de operadores matemáticos e lógica booleana. O objetivo desse tipo de operação é 
estabelecer uma hierarquia e combinação de condições que devem ser satisfeitas para determinar a aptidão de determinado ponto geográfico.

Neste modelo as informações são hierarquizadas conforme o detalhamento da escala ou resolução espacial dos dados de origem e, posteriormente, seguindo a combinação razoável de princípios agronômicos. Nesse sentido, as restrições de topografia são precedentes às de solos e clima.

No cálculo final ainda são incluídas informações de uso da terra e biomas. Isso é necessário para desconsiderar massas d'água e áreas urbanas da avaliação e também para filtrar o efeito de aplainamento do relevo que o dossel da floresta amazônica tem no cálculo da declividade do terreno bem como para evitar a interpretação errônea de área planas inundáveis no Pantanal como sendo de alta aptidão agrícola. As Figuras 8 a 11 ilustram de maneira simplificada o processo de cálculo de índices e integração.

\section{Dados utilizados}

O objetivo na escolha das bases de dados é equacionar a disponibilidade de dados, o nível de detalhamento e o grau de confiabilidade das informações. Nesse sentido, os dados básicos utilizados na modelagem são oriundos de bases secundárias de acesso predominantemente gratuito e seguem resumidas na Tabela 15 apresentada a seguir.

Tabela 15. Fonte dos dados de alimentação do modelo de Aptidão.

\begin{tabular}{|c|c|c|c|c|}
\hline Dimensão & Fonte das informações & Data & $\begin{array}{l}\text { Escala ou } \\
\text { Resolução } \\
\text { espacial }\end{array}$ & $\begin{array}{l}\text { Formato } \\
\quad \text { dos } \\
\text { arquivos }\end{array}$ \\
\hline \multirow[b]{2}{*}{ Solos } & Múltiplas fontes & múltiplas & múltiplas & Shapefile \\
\hline & $\begin{array}{l}\text { ESALQ - Banco de dados de perfis pedológicos do projeto } \\
\text { RADAM-BRASIL http://www.esalq.usp.br/gerd/ }\end{array}$ & 2005 & pontual & $\begin{array}{c}\text { Banco de } \\
\text { dados }\end{array}$ \\
\hline \multirow{3}{*}{ Clima } & $\begin{array}{l}\text { FAO - Banco de dados FAOCLIM de precipitação e } \\
\text { temperatura médias mensais (1025 estações) } \\
\text { http://www.fao.org/nr/climpag/pub/en1102_en.asp }\end{array}$ & 2001 & pontual & $\begin{array}{l}\text { Banco de } \\
\text { dados }\end{array}$ \\
\hline & $\begin{array}{l}\text { INMET e DAAE - Banco de dados de precipitação e } \\
\text { temperatura médias mensais( } 283 \text { estações) }\end{array}$ & $\begin{array}{c}\text { não } \\
\text { publicado }\end{array}$ & pontual & $\begin{array}{l}\text { Banco de } \\
\text { dados }\end{array}$ \\
\hline & $\begin{array}{l}\text { ANA - Banco de dados hidroweb de precipitação (2676 } \\
\text { estações) } \\
\text { http://hidroweb.ana.gov.br/ }\end{array}$ & 2005 & pontual & $\begin{array}{l}\text { Banco de } \\
\text { dados }\end{array}$ \\
\hline Relevo & 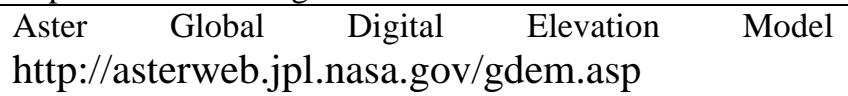 & 2011 & $30 \mathrm{~m} \times 30 \mathrm{~m}$ & Geotiff \\
\hline
\end{tabular}

Fonte: Sparovek (2015) 


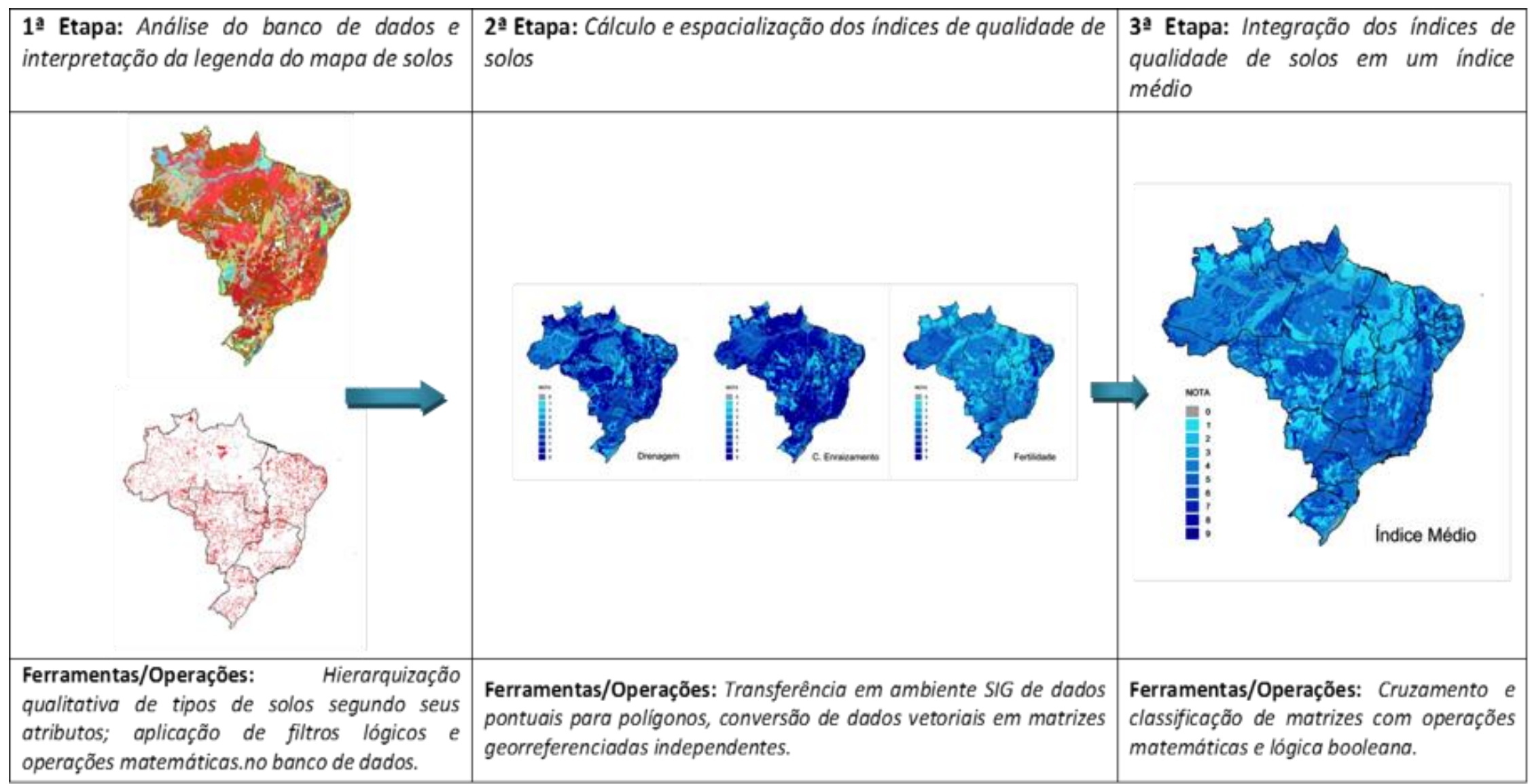

Figura 8. Esquema simplificado de geração do índice médio de qualidade de solos.

Fonte: Sparovek (2015) 


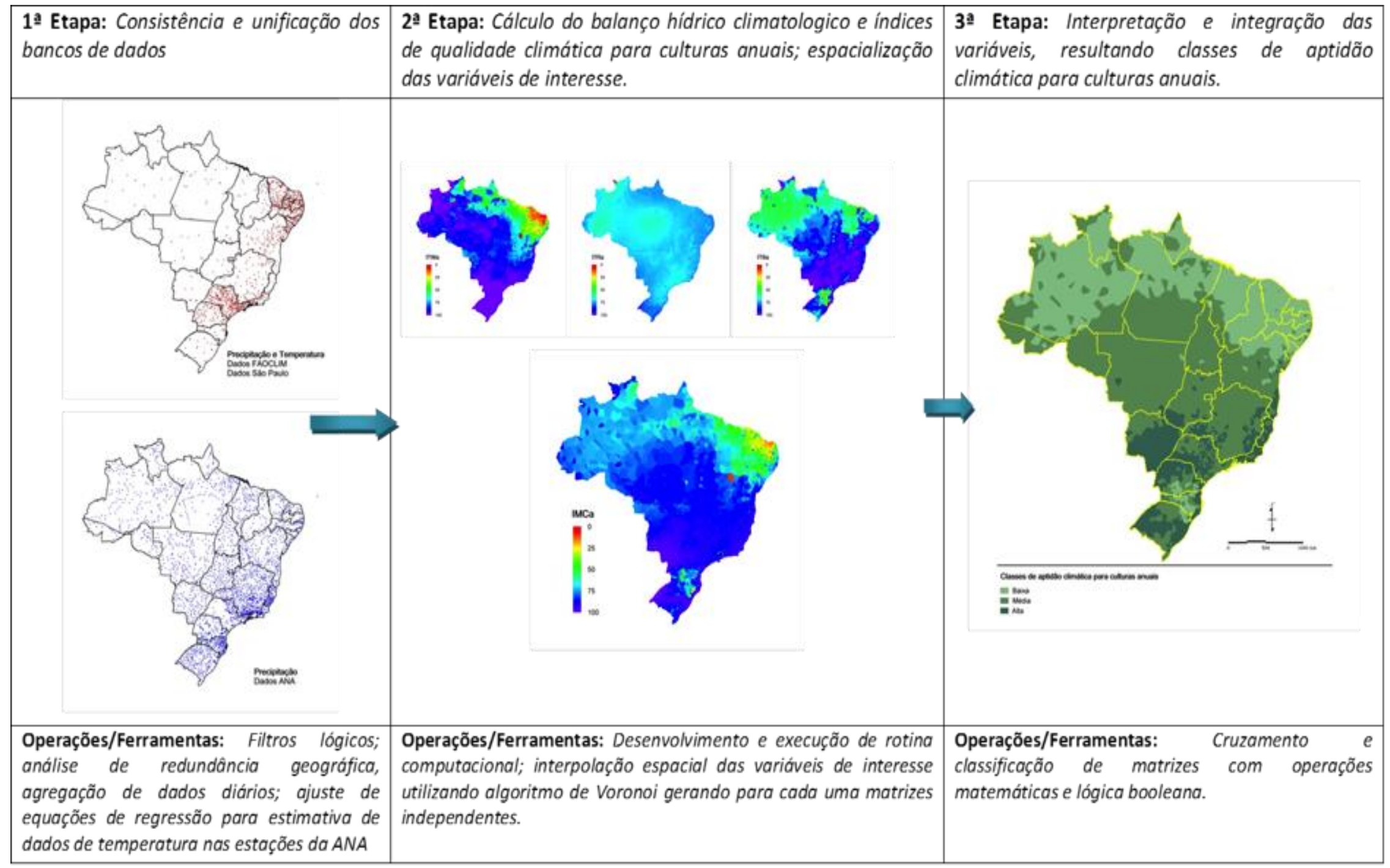

Figura 9. Esquema simplificado de geração das classes de aptidão climática para culturas anuais.

Fonte: Sparovek (2015) 


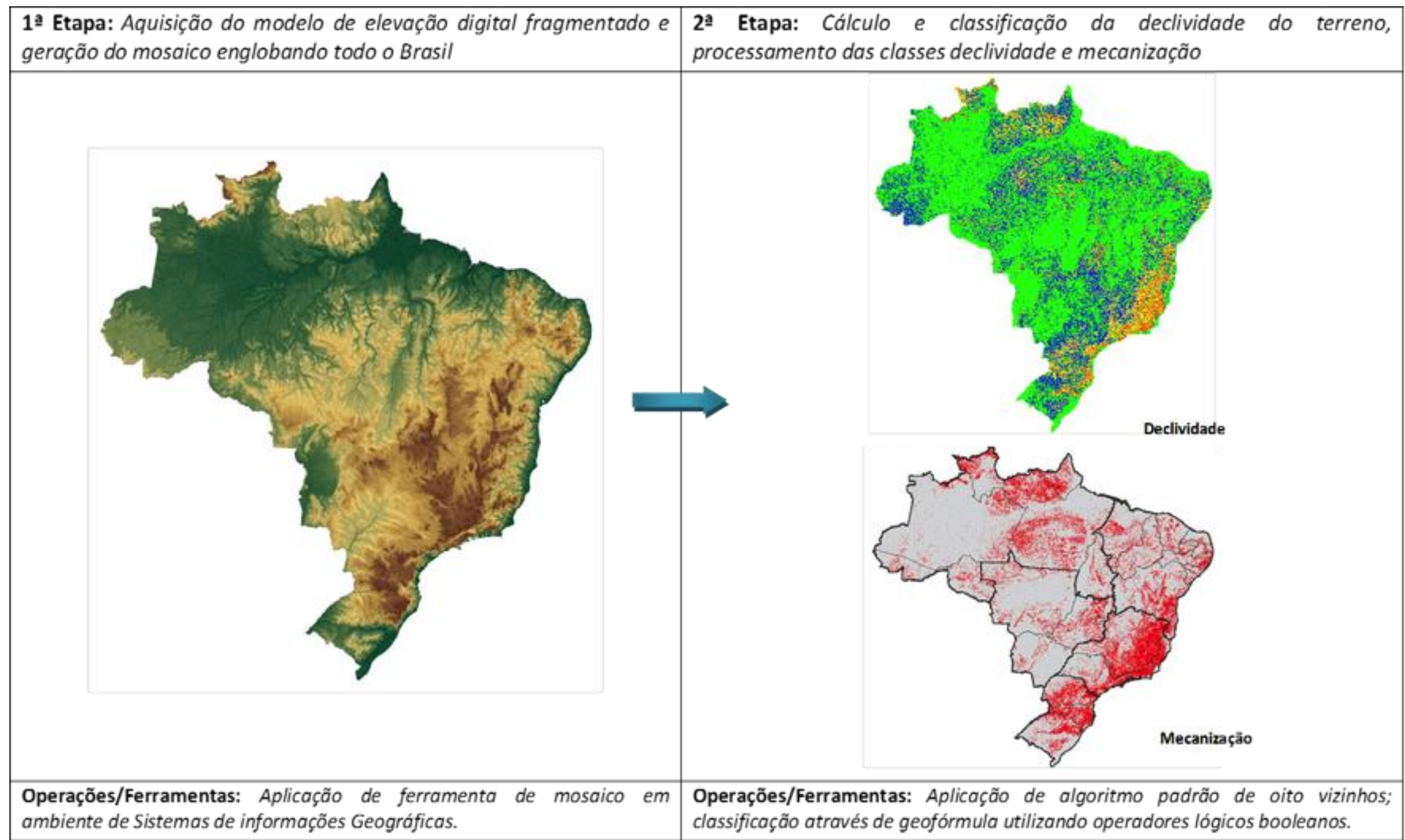

Figura 10. Esquema simplificado de cálculo das classes de declividade do terreno.

Fonte: Sparovek (2015) 


\begin{tabular}{l}
$\begin{array}{l}\text { Etapa final: Integração dos temas: Solos, Clima e } \\
\text { Topografia com adição de informações de uso-da- } \\
\text { terra. }\end{array}$ \\
\hline Resultado: Classes de aptidão agrícola para culturas agrícolas. \\
\hline $\begin{array}{l}\text { Operações/Ferramentas: Operação de matrizes } \\
\text { georreferenciadas }\end{array}$
\end{tabular}

Figura 11. Esquema simplificado de integração das dimensões solos, clima e topografia na geração das classes de aptidão agrícola. Fonte: Sparovek (2015) 
ANEXO B. Premissas metodológicas e bases de dados de clima ${ }^{23}$

As condições climáticas definem em grande parte o rendimento das culturas e podem também indicar a necessidade de irrigação para reduzir os riscos de quebra de safra. Os componentes do clima (precipitação, radiação e temperatura) são convertidos em três índices variando de 1 a 10 que representam diferentes aspectos ligados à relação existente entre clima e rendimento para culturas anuais. Especificamente para cana-de-açúcar que possui fisiologia e ciclo de cultivo diferenciados, foram avaliados diretamente o déficit hídrico anual e a temperatura média anual como parâmetros de avaliação de aptidão climática.

O cálculo destes índices é feito com base no banco de dados georreferenciado contendo dados de temperatura e precipitação normais além de dados de radiação solar obtidos a partir da digitalização do Atlas Solarimétrico do Brasil ${ }^{24}$ (Chigueru Tiba et al., 2000). A partir dos dados é calculado o balanço hídrico climatológico (Thornthwaite \& Mather 1955) e índices de qualidade climática para culturas agrícolas utilizando-se uma rotina computacional especificamente desenvolvida para essa finalidade.

Foram utilizados 2 bases de dados de estações meteorológicas para conseguir uma cobertura completa do Brasil: i) Base FAOCLIM (1025 estações); e, ii) Base São Paulo (DAAE + INMET - 283 estações). Além das bases de dados mencionadas foi utilizada também a base de dados da Agência Nacional de Águas (ANA) contendo dados de precipitação de 2076 estações no Brasil. Como nessas estações não há dados de temperatura, foram aplicadas equações de regressão linear múltipla para derivar os dados de temperatura média mensal em função dos dados de latitude, longitude e altitude das estações. O detalhamento desse procedimento está descrito abaixo.

A cobertura espacial dos bancos de dados utilizados está mostrada na Figura 12 e os índices calculados seguem descritos nos itens subsequentes.

23 Este anexo foi extraído de Sparovek (2015) retratando a construção da variável de Aptidão Agrícola.

24 O Atlas Solarimétrico do Brasil (Chigueru Tiba et al. Ed Universitária da UFPE, 2000) apresenta uma estimativa da radiação solar incidente no país, resultante da interpolação e extrapolação de dados obtidos em estações solarimétricas distribuídas em vários pontos do território nacional. Devido, porém, ao número relativamente reduzido de estações experimentais e às variações climáticas locais e regionais, o Atlas de Irradiação Solar no Brasil faz estimativas da radiação solar a partir de imagens de satélites. 

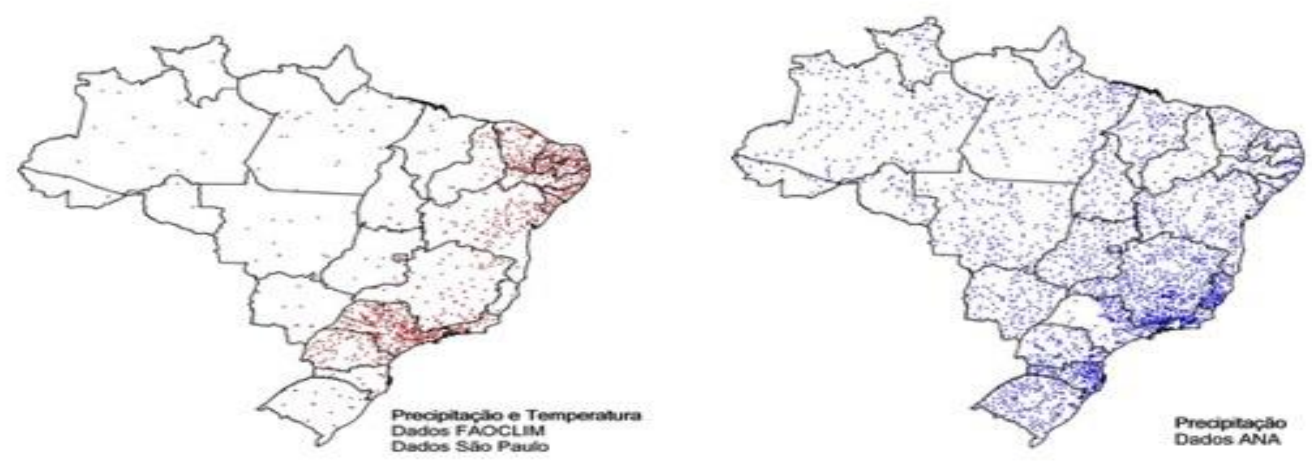

Figura 12. Bases de dados climáticos utilizadas.

Fonte: Sparovek (2015)

\section{Estimativa de temperatura do ar}

Com a finalidade de ampliar a rede de dados climatológicos utilizada na análise de aptidão climática para culturas agrícolas, foram obtidos os dados compilados pela rede hidrometeorológica da Agência Nacional de Águas (ANA) (http://hidroweb.ana.gov.br/) que reúne dados sobre vazões, chuvas, evaporimetria, qualidade da água e sedimentos. Entretanto, as estações que coletam essas informações não coletam dados de temperatura necessários para cálculo do balanço hídrico climatológico utilizado na composição dos índices de qualidade climática para culturas agrícolas.

Dessa forma foi feita uma revisão bibliográfica no sentido de selecionar trabalhos científicos consistentes que oferecessem estimativas de temperaturas mínimas, máximas e médias mensais com base em equações de regressão linear múltipla em que as variáveis independentes utilizadas fossem a longitude, latitude e altitude.

As referências utilizadas para cada uma das regiões do Brasil estão esquematizadas na Figura 13. Os critérios utilizados para inclusão dos dados nas regressões e nas bases climáticas foi um número mínimo de 10 anos para cálculo de média e nenhuma ausência nos dados de Temperatura, Radiação ou Precipitação. Aplicando-se esses critérios, foram descartados dados de 298 estações, equivalente a $11 \%$ do total das estações hidrometeorológicas da ANA. 


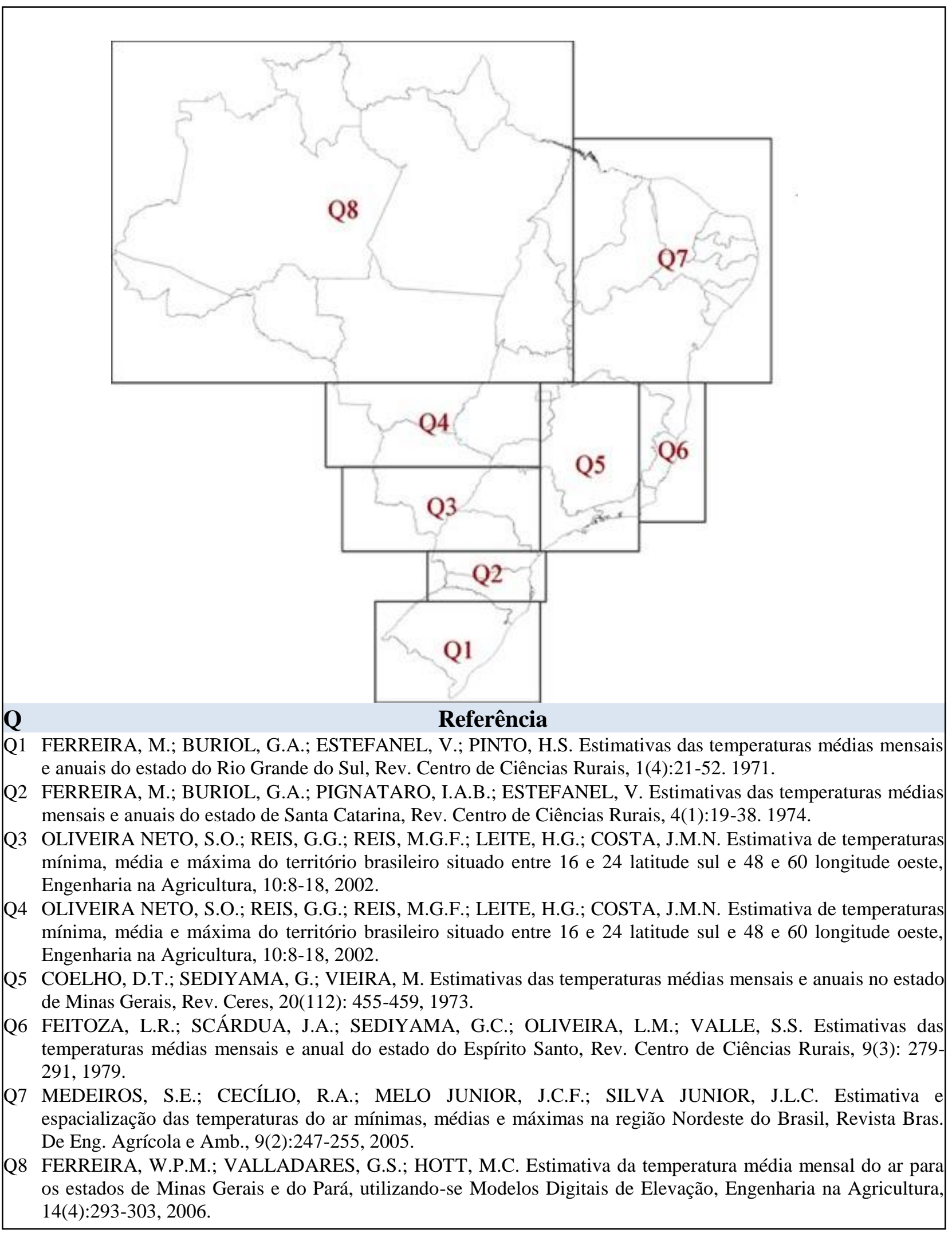

Figura 13. Referência das equações de regressão utilizadas em cada uma das regiões do Brasil para estimativa da temperatura média mensal

Fonte: Sparovek (2015) 
ANEXO C. Distribuição dos Recursos do Programa ABC por Unidade da Federação

As tabelas presentes neste Anexo utilizam informações contidas na "Base 1". Os dados disponíveis são complementares aos apresentados nos resultados deste trabalho. 
Tabela 16. Crédito concedido por subprograma, região e APT, em relação ao total da região. Em porcentagem (\%)

\begin{tabular}{|c|c|c|c|c|c|c|c|c|c|c|c|c|c|c|c|c|c|c|c|c|c|c|}
\hline Região & \multicolumn{7}{|c|}{ Apt. A } & \multicolumn{7}{|c|}{ Apt. B } & \multicolumn{7}{|c|}{$\begin{array}{l}\text { Apt. CD } \\
\end{array}$} & TOTAL \\
\hline Norte & 0,9 & 0,0 & 0,0 & 0,2 & 0,0 & 0,1 & 0,2 & 46,2 & 4,6 & 0,7 & 1,2 & 0,0 & 0,0 & 3,3 & 24,7 & 8,1 & 1,8 & 3,5 & 0,0 & 0,0 & 4,6 & 100 \\
\hline $\mathrm{AC}$ & 0,0 & 0,0 & 0,0 & 0,0 & 0,0 & 0,0 & 0,0 & 84,5 & 0,0 & 2,2 & 0,0 & 0,0 & 0,0 & 3,1 & 9,5 & 0,0 & 0,0 & 0,0 & 0,0 & 0,0 & 0,7 & 100 \\
\hline $\mathrm{AP}$ & 0,0 & 0,0 & 0,0 & 0,0 & 0,0 & 0,0 & 0,0 & 0,0 & 0,0 & 0,0 & 0,0 & 0,0 & 0,0 & 0,0 & 46,1 & 53,9 & 0,0 & 0,0 & 0,0 & 0,0 & 0,0 & 100 \\
\hline RO & 2,8 & 0,0 & 0,0 & 0,0 & 0,0 & 0,0 & 0,0 & 61,5 & 3,6 & 0,0 & 1,5 & 0,3 & 0,0 & 6,2 & 18,4 & 0,0 & 0,5 & 3,4 & 0,0 & 0,0 & 1,7 & 100 \\
\hline RR & 0,0 & 0,0 & 0,0 & 0,0 & 0,0 & 0,0 & 0,0 & 0,0 & 0,0 & 0,0 & 0,0 & 0,0 & 0,0 & 0,0 & 47,9 & 30,4 & 21,7 & 0,0 & 0,0 & 0,0 & 0,0 & 100 \\
\hline TO & 1,0 & 0,0 & 0,0 & 0,3 & 0,0 & 0,2 & 0,3 & 30,3 & 7,1 & 0,6 & 1,9 & 0,0 & 0,0 & 2,2 & 33,3 & 13,4 & 2,2 & 5,6 & 0,0 & 0,0 & 1,5 & 100 \\
\hline MA & 1,9 & 0,0 & 0,0 & 0,0 & 0,0 & 0,0 & 0,0 & 3,5 & 0,1 & 0,4 & 0,0 & 0,0 & 0,0 & 0,0 & 58,9 & 30,5 & 2,1 & 2,6 & 0,0 & 0,0 & 0,0 & 100 \\
\hline PE & 0,0 & 0,0 & 0,0 & 0,0 & 0,0 & 0,0 & 0,0 & 2,8 & 0,0 & 0,0 & 0,0 & 0,0 & 0,0 & 0,0 & 80,7 & 0,0 & 15,9 & 0,6 & 0,0 & 0,0 & 0,0 & 100 \\
\hline PI & 0,0 & 0,0 & 0,0 & 0,0 & 0,0 & 0,0 & 0,0 & 0,0 & 6,5 & 0,0 & 0,0 & 0,0 & 0,0 & 0,0 & 9,5 & 82,1 & 0,5 & 1,3 & 0,0 & 0,0 & 0,0 & 100 \\
\hline Centro-Oeste & 11,7 & 11,0 & 1,3 & 2,7 & 0,0 & 0,0 & 0,5 & 28,8 & 10,6 & 2,9 & 2,6 & 0,0 & 0,0 & 0,2 & 16,4 & 2,3 & 2,3 & 6,6 & 0,0 & 0,0 & 0,1 & 100 \\
\hline GO & 11,3 & 12,5 & 0,9 & 2,6 & 0,0 & 0,0 & 0,0 & 38,6 & 11,4 & 4,9 & 2,0 & 0,0 & 0,0 & 0,2 & 12,0 & 1,6 & 0,8 & 1,2 & 0,0 & 0,0 & 0,0 & 100 \\
\hline MT & 2,4 & 7,6 & 0,3 & 0,9 & 0,0 & 0,0 & 0,4 & 33,4 & 19,7 & 2,5 & 2,5 & 0,0 & 0,0 & 0,6 & 20,7 & 4,1 & 3,6 & 0,9 & 0,0 & 0,0 & 0,2 & 100 \\
\hline MS & 20,7 & 12,1 & 2,9 & 4,7 & 0,0 & 0,0 & 1,1 & 11,2 & 0,9 & 0,6 & 3,5 & 0,0 & 0,1 & 0,0 & 18,4 & 1,5 & 3,0 & 19,2 & 0,0 & 0,0 & 0,1 & 100 \\
\hline SP & 27,6 & 20,2 & 5,6 & 12,4 & 0,0 & 0,0 & 0,0 & 12,9 & 5,6 & 3,3 & 7,2 & 0,0 & 0,0 & 0,0 & 1,5 & 0,4 & 0,9 & 2,3 & 0,0 & 0,0 & 0,0 & 100 \\
\hline Sul & 12,3 & 8,3 & 1,1 & 1,7 & 0,0 & 0,3 & 0,0 & 8,9 & 14,2 & 1,8 & 2,6 & 0,7 & 0,0 & 0,0 & 22,3 & 12,2 & 4,3 & 8,2 & 0,1 & 1,0 & 0,0 & 100 \\
\hline $\mathrm{PR}$ & 14,1 & 7,5 & 1,3 & 3,0 & 0,0 & 0,8 & 0,0 & 10,9 & 5,8 & 0,8 & 4,9 & 0,5 & 0,0 & 0,0 & 22,0 & 8,7 & 3,8 & 15,1 & 0,1 & 0,7 & 0,0 & 100 \\
\hline RS & 13,4 & 10,7 & 1,2 & 0,6 & 0,0 & 0,0 & 0,0 & 8,7 & 21,2 & 2,8 & 1,3 & 0,9 & 0,0 & 0,0 & 19,4 & 14,1 & 3,9 & 1,6 & 0,0 & 0,1 & 0,0 & 100 \\
\hline SC & 0,0 & 0,0 & 0,0 & 1,8 & 0,0 & 0,0 & 0,0 & 1,3 & 14,6 & 0,7 & 0,2 & 0,0 & 0,0 & 0,0 & 37,6 & 17,0 & 8,7 & 11,7 & 0,0 & 6,4 & 0,0 & 100 \\
\hline Brasil & 11,8 & 11,3 & 2,0 & 3,8 & 0,0 & 0,1 & 0,2 & 22,2 & 8,2 & 2,9 & 4,0 & 0,1 & 0,0 & 0,5 & 17,8 & 6,2 & 2,5 & 5,5 & 0,0 & 0,2 & 0,6 & 100 \\
\hline
\end{tabular}

Fonte: resultados da pesquisa. 
Tabela 17. Área por subprograma, região e APT, em relação ao total da região. Em porcentagem (\%)

\begin{tabular}{|c|c|c|c|c|c|c|c|c|c|c|c|c|c|c|c|c|c|c|c|c|c|c|}
\hline \multirow{2}{*}{ Região } & \multicolumn{7}{|c|}{ Apt. A } & \multicolumn{7}{|c|}{ Apt. B } & \multicolumn{7}{|c|}{ Apt. CD } & \multirow{2}{*}{ TOTAL } \\
\hline & RPD & SPD & iLPF & FLP & ARA & TDA & OUT & RPD & SPD & iLPF & FLP & ARA & TDA & OUT & RPD & SPD & iLPF & FLP & ARA & TDA & OUT & \\
\hline Norte & 0,5 & 0,0 & 0,0 & 0,1 & 0,0 & 0,0 & 0,0 & 39,5 & 7,8 & 1,2 & 0,7 & 0,0 & 0,0 & 1,0 & 25,6 & 16,2 & 2,4 & 3,2 & 0,0 & 0,0 & 1,9 & 100 \\
\hline $\mathrm{AC}$ & 0,0 & 0,0 & 0,0 & 0,0 & 0,0 & 0,0 & 0,0 & 80,2 & 0,0 & 2,7 & 0,0 & 0,0 & 0,0 & 3,8 & 11,8 & 0,0 & 0,0 & 0,0 & 0,0 & 0,0 & 1,5 & 100 \\
\hline $\mathrm{AP}$ & 0,0 & 0,0 & 0,0 & 0,0 & 0,0 & 0,0 & 0,0 & 0,0 & 0,0 & 0,0 & 0,0 & 0,0 & 0,0 & 0,0 & 56,5 & 43,5 & 0,0 & 0,0 & 0,0 & 0,0 & 0,0 & 100 \\
\hline PA & 0,0 & 0,0 & 0,0 & 0,0 & 0,0 & 0,0 & 0,0 & 73,8 & 4,1 & 1,0 & 0,2 & 0,0 & 0,0 & 0,4 & 11,4 & 0,9 & 0,3 & 0,5 & 0,0 & 0,0 & 7,5 & 100 \\
\hline RO & 1,5 & 0,0 & 0,0 & 0,0 & 0,0 & 0,0 & 0,0 & 38,0 & 0,1 & 0,0 & 0,6 & 0,2 & 0,0 & 4,2 & 53,5 & 0,0 & 0,3 & 0,7 & 0,0 & 0,0 & 0,8 & 100 \\
\hline RR & 0,0 & 0,0 & 0,0 & 0,0 & 0,0 & 0,0 & 0,0 & 0,0 & 0,0 & 0,0 & 0,0 & 0,0 & 0,0 & 0,0 & 11,8 & 75,7 & 12,6 & 0,0 & 0,0 & 0,0 & 0,0 & 100 \\
\hline TO & 0,5 & 0,0 & 0,0 & 0,2 & 0,0 & 0,0 & 0,0 & 29,2 & 12,4 & 1,6 & 1,0 & 0,0 & 0,0 & 0,2 & 24,1 & 22,0 & 3,1 & 5,2 & 0,0 & 0,0 & 0,5 & 100 \\
\hline Nordeste & 3,5 & 38,4 & 0,6 & 0,8 & 0,0 & 0,0 & 0,0 & 2,9 & 2,9 & 0,4 & 0,4 & 0,0 & 0,0 & 0,0 & 12,2 & 36,1 & 0,5 & 1,3 & 0,0 & 0,0 & 0,0 & 100 \\
\hline BA & 5,2 & 59,2 & 0,9 & 1,2 & 0,0 & 0,0 & 0,0 & 3,9 & 3,0 & 0,5 & 0,7 & 0,0 & 0,0 & 0,0 & 7,1 & 17,3 & 0,5 & 0,4 & 0,0 & 0,0 & 0,0 & 100 \\
\hline MA & 0,5 & 0,0 & 0,0 & 0,0 & 0,0 & 0,0 & 0,0 & 1,6 & 0,0 & 0,1 & 0,0 & 0,0 & 0,0 & 0,0 & 33,6 & 59,0 & 0,8 & 4,3 & 0,0 & 0,0 & 0,0 & 100 \\
\hline $\mathrm{PE}$ & 0,0 & 0,0 & 0,0 & 0,0 & 0,0 & 0,0 & 0,0 & 0,0 & 0,0 & 0,0 & 0,0 & 0,0 & 0,0 & 0,0 & 88,8 & 0,0 & 11,2 & 0,0 & 0,0 & 0,0 & 0,0 & 100 \\
\hline PI & 0,0 & 0,0 & 0,0 & 0,0 & 0,0 & 0,0 & 0,0 & 0,0 & 6,4 & 0,0 & 0,0 & 0,0 & 0,0 & 0,0 & 2,7 & 89,6 & 0,0 & 1,3 & 0,0 & 0,0 & 0,0 & 100 \\
\hline Centro-Oeste & 6,0 & 10,6 & 0,6 & 1,0 & 0,0 & 0,0 & 0,3 & 16,5 & 10,2 & 38,6 & 0,9 & 0,0 & 0,0 & 0,4 & 9,3 & 2,2 & 1,2 & 2,0 & 0,0 & 0,0 & 0,1 & 100 \\
\hline $\mathrm{GO}$ & 3,9 & 6,8 & 0,3 & 0,5 & 0,0 & 0,0 & 0,0 & 15,9 & 5,8 & 60,4 & 0,3 & 0,0 & 0,0 & 0,1 & 4,9 & 0,8 & 0,1 & 0,2 & 0,0 & 0,0 & 0,0 & 100 \\
\hline MT & 1,5 & 15,3 & 0,2 & 0,6 & 0,0 & 0,0 & 1,0 & 21,2 & 29,5 & 2,1 & 2,1 & 0,0 & 0,0 & 1,7 & 14,9 & 6,5 & 3,0 & 0,3 & 0,0 & 0,0 & 0,3 & 100 \\
\hline MS & 21,4 & 19,5 & 2,4 & 3,8 & 0,0 & 0,0 & 0,7 & 12,7 & 1,5 & 0,2 & 1,4 & 0,0 & 0,0 & 0,0 & 19,9 & 1,9 & 2,9 & 11,7 & 0,0 & 0,0 & 0,1 & 100 \\
\hline Sudeste & 17,4 & 9,8 & 2,2 & 8,3 & 0,0 & 0,0 & 0,0 & 14,8 & 11,3 & 2,9 & 7,0 & 0,6 & 0,0 & 0,0 & 16,5 & 3,0 & 1,7 & 4,4 & 0,0 & 0,0 & 0,0 & 100 \\
\hline ES & 23,0 & 4,3 & 10,0 & 4,2 & 0,0 & 0,0 & 0,0 & 9,6 & 0,0 & 0,2 & 0,0 & 0,0 & 0,0 & 0,0 & 37,1 & 1,3 & 5,7 & 4,5 & 0,0 & 0,0 & 0,1 & 100 \\
\hline $\mathrm{MG}$ & 9,8 & 5,7 & 1,1 & 3,9 & 0,0 & 0,0 & 0,0 & 15,7 & 15,7 & 3,7 & 6,8 & 1,0 & 0,0 & 0,0 & 23,7 & 4,7 & 2,3 & 6,0 & 0,0 & 0,1 & 0,0 & 100 \\
\hline RJ & 1,5 & 0,0 & 1,6 & 0,8 & 0,0 & 0,0 & 0,0 & 0,0 & 0,0 & 0,0 & 0,0 & 0,0 & 0,0 & 0,0 & 86,5 & 0,0 & 1,6 & 7,3 & 0,0 & 0,8 & 0,0 & 100 \\
\hline SP & 30,7 & 17,8 & 3,4 & 16,6 & 0,0 & 0,0 & 0,0 & 13,7 & 4,6 & 1,7 & 8,0 & 0,0 & 0,0 & 0,0 & 1,2 & 0,3 & 0,5 & 1,6 & 0,0 & 0,0 & 0,0 & 100 \\
\hline Sul & 4,1 & 9,3 & 19,7 & 0,3 & 0,0 & 0,0 & 0,0 & 3,4 & 13,9 & 1,2 & 0,7 & 0,0 & 0,0 & 0,0 & 8,2 & 11,5 & 1,4 & 26,1 & 0,0 & 0,0 & 0,0 & 100 \\
\hline PR & 3,3 & 7,2 & 0,2 & 0,5 & 0,0 & 0,0 & 0,0 & 1,8 & 4,7 & 0,3 & 1,2 & 0,1 & 0,0 & 0,0 & 6,2 & 7,6 & 2,1 & 64,9 & 0,0 & 0,0 & 0,0 & 100 \\
\hline $\mathrm{RS}$ & 5,0 & 11,4 & 34,9 & 0,1 & 0,0 & 0,0 & 0,0 & 4,8 & 20,1 & 1,8 & 0,4 & 0,0 & 0,0 & 0,0 & 6,8 & 13,6 & 0,8 & 0,3 & 0,0 & 0,0 & 0,0 & 100 \\
\hline $\mathrm{SC}$ & 0,0 & 0,0 & 0,0 & 1,0 & 0,0 & 0,0 & 0,0 & 1,1 & 17,9 & 0,3 & 0,1 & 0,0 & 0,0 & 0,0 & 50,5 & 21,5 & 2,1 & 5,5 & 0,0 & 0,0 & 0,0 & 100 \\
\hline Brasil & 6,5 & 12,0 & 4,8 & 1,8 & 0,0 & 0,0 & 0,2 & 14,2 & 10,2 & 18,9 & 1,6 & 0,1 & 0,0 & 0,3 & 11,8 & 8,7 & 1,3 & 7,4 & 0,0 & 0,0 & 0,2 & 100 \\
\hline
\end{tabular}

Fonte: resultados da pesquisa. 
Tabela 18. Contratos por subprograma, região e APT, em relação ao total da região. Em porcentagem (\%)

\begin{tabular}{|c|c|c|c|c|c|c|c|c|c|c|c|c|c|c|c|c|c|c|c|c|c|c|}
\hline \multirow{2}{*}{ Região } & \multicolumn{7}{|c|}{ Apt. A } & \multicolumn{7}{|c|}{ Apt. B } & \multicolumn{7}{|c|}{ Apt. CD } & \multirow{2}{*}{ TOTAL } \\
\hline & RPD & SPD & iLPF & FLP & ARA & TDA & OUT & RPD & SPD & iLPF & FLP & ARA & TDA & OUT & RPD & SPD & iLPF & FLP & ARA & TDA & OUT & \\
\hline Norte & 1,2 & 0,0 & 0,0 & 0,2 & 0,0 & 0,1 & 0,1 & 47,5 & 4,4 & 0,6 & 1,1 & 0,1 & 0,0 & 1,5 & 29,8 & 8,2 & 1,7 & 2,6 & 0,0 & 0,0 & 1,1 & 100 \\
\hline $\mathrm{AC}$ & 0,0 & 0,0 & 0,0 & 0,0 & 0,0 & 0,0 & 0,0 & 86,7 & 0,0 & 1,8 & 0,0 & 0,0 & 0,0 & 5,4 & 5,4 & 0,0 & 0,0 & 0,0 & 0,0 & 0,0 & 0,6 & 100 \\
\hline $\mathrm{AP}$ & 0,0 & 0,0 & 0,0 & 0,0 & 0,0 & 0,0 & 0,0 & 0,0 & 0,0 & 0,0 & 0,0 & 0,0 & 0,0 & 0,0 & 30,8 & 69,2 & 0,0 & 0,0 & 0,0 & 0,0 & 0,0 & 100 \\
\hline $\mathrm{PA}$ & 0,0 & 0,0 & 0,0 & 0,0 & 0,0 & 0,0 & 0,0 & 71,0 & 2,6 & 0,6 & 0,6 & 0,0 & 0,0 & 1,8 & 17,9 & 1,5 & 1,2 & 0,6 & 0,0 & 0,0 & 2,3 & 100 \\
\hline $\mathrm{RO}$ & 4,2 & 0,0 & 0,0 & 0,0 & 0,0 & 0,0 & 0,0 & 63,9 & 2,3 & 0,0 & 1,5 & 0,4 & 0,0 & 2,7 & 23,2 & 0,0 & 0,4 & 0,4 & 0,0 & 0,0 & 1,1 & 100 \\
\hline RR & 0,0 & 0,0 & 0,0 & 0,0 & 0,0 & 0,0 & 0,0 & 0,0 & 0,0 & 0,0 & 0,0 & 0,0 & 0,0 & 0,0 & 58,3 & 25,0 & 16,7 & 0,0 & 0,0 & 0,0 & 0,0 & 100 \\
\hline TO & 1,0 & 0,0 & 0,0 & 0,3 & 0,0 & 0,1 & 0,2 & 32,6 & 6,1 & 0,6 & 1,3 & 0,0 & 0,0 & 0,7 & 37,8 & 12,3 & 2,1 & 4,1 & 0,0 & 0,0 & 0,9 & 100 \\
\hline Nordeste & 5,2 & 22,2 & 1,4 & 1,6 & 0,0 & 0,0 & 0,1 & 6,2 & 2,2 & 1,1 & 2,2 & 0,0 & 0,0 & 0,0 & 35,6 & 19,0 & 1,5 & 1,8 & 0,0 & 0,0 & 0,1 & 100 \\
\hline $\mathrm{BA}$ & 8,1 & 38,7 & 2,4 & 2,8 & 0,0 & 0,0 & 0,1 & 9,4 & 2,7 & 1,8 & 3,9 & 0,0 & 0,0 & 0,0 & 17,4 & 10,1 & 1,2 & 1,2 & 0,0 & 0,0 & 0,1 & 100 \\
\hline MA & 1,8 & 0,0 & 0,0 & 0,0 & 0,0 & 0,0 & 0,0 & 1,8 & 0,2 & 0,2 & 0,0 & 0,0 & 0,0 & 0,0 & 70,1 & 21,7 & 1,4 & 2,6 & 0,0 & 0,0 & 0,0 & 100 \\
\hline $\mathrm{PE}$ & 0,0 & 0,0 & 0,0 & 0,0 & 0,0 & 0,0 & 0,0 & 2,8 & 0,0 & 0,0 & 0,0 & 0,0 & 0,0 & 0,0 & 83,3 & 0,0 & 11,1 & 2,8 & 0,0 & 0,0 & 0,0 & 100 \\
\hline PI & 0,0 & 0,0 & 0,0 & 0,0 & 0,0 & 0,0 & 0,0 & 0,0 & 7,4 & 0,0 & 0,0 & 0,0 & 0,0 & 0,0 & 10,7 & 79,3 & 0,8 & 1,7 & 0,0 & 0,0 & 0,0 & 100 \\
\hline Centro-Oeste & 15,4 & 9,8 & 0,9 & 2,1 & 0,0 & 0,0 & 0,2 & 34,7 & 10,0 & 2,0 & 2,1 & 0,0 & 0,0 & 0,2 & 17,9 & 2,3 & 0,9 & 1,3 & 0,0 & 0,0 & 0,1 & 100 \\
\hline $\mathrm{GO}$ & 13,6 & 8,6 & 0,8 & 1,7 & 0,0 & 0,0 & 0,0 & 42,6 & 9,9 & 2,6 & 1,8 & 0,0 & 0,0 & 0,3 & 14,1 & 2,1 & 0,8 & 1,1 & 0,0 & 0,0 & 0,0 & 100 \\
\hline MT & 2,1 & 7,7 & 0,2 & 0,3 & 0,0 & 0,0 & 0,2 & 36,3 & 20,3 & 2,1 & 3,2 & 0,1 & 0,1 & 0,2 & 22,0 & 3,2 & 1,1 & 0,8 & 0,0 & 0,0 & 0,2 & 100 \\
\hline MS & 30,8 & 14,1 & 1,6 & 4,6 & 0,0 & 0,0 & 0,8 & 16,4 & 1,5 & 0,7 & 1,9 & 0,0 & 0,1 & 0,0 & 22,5 & 1,9 & 1,1 & 1,9 & 0,0 & 0,0 & 0,1 & 100 \\
\hline Sudeste & 19,7 & 10,7 & 3,5 & 8,4 & 0,0 & 0,0 & 0,0 & 15,6 & 4,9 & 3,9 & 7,3 & 0,0 & 0,0 & 0,0 & 16,6 & 1,3 & 2,7 & 5,0 & 0,0 & 0,2 & 0,0 & 100 \\
\hline $\mathrm{ES}$ & 11,3 & 1,1 & 13,4 & 6,7 & 0,0 & 0,0 & 0,0 & 1,8 & 0,0 & 1,1 & 0,0 & 0,0 & 0,0 & 0,0 & 30,4 & 2,8 & 20,1 & 10,6 & 0,0 & 0,4 & 0,4 & 100 \\
\hline MG & 13,1 & 4,4 & 1,4 & 3,8 & 0,0 & 0,1 & 0,0 & 18,2 & 5,7 & 4,7 & 7,1 & 0,1 & 0,1 & 0,0 & 28,9 & 2,1 & 3,4 & 6,8 & 0,0 & 0,3 & 0,0 & 100 \\
\hline RJ & 3,4 & 0,0 & 1,1 & 1,1 & 0,0 & 0,0 & 0,0 & 0,0 & 0,0 & 0,0 & 0,0 & 0,0 & 0,0 & 0,0 & 80,5 & 1,1 & 1,1 & 10,3 & 0,0 & 1,1 & 0,0 & 100 \\
\hline SP & 27,2 & 17,8 & 5,0 & 13,2 & 0,0 & 0,1 & 0,0 & 14,4 & 4,5 & 3,3 & 8,1 & 0,0 & 0,0 & 0,0 & 2,2 & 0,5 & 0,9 & 2,8 & 0,0 & 0,0 & 0,0 & 100 \\
\hline Sul & 9,0 & 11,2 & 0,8 & 2,5 & 0,0 & 0,2 & 0,0 & 7,8 & 15,4 & 1,3 & 2,5 & 0,2 & 0,0 & 0,0 & 21,0 & 15,8 & 3,7 & 8,1 & 0,1 & 0,6 & 0,0 & 100 \\
\hline PR & 10,4 & 14,4 & 0,7 & 5,0 & 0,0 & 0,4 & 0,0 & 9,9 & 7,3 & 0,9 & 4,3 & 0,3 & 0,0 & 0,0 & 19,3 & 12,9 & 3,0 & 10,5 & 0,1 & 0,5 & 0,0 & 100 \\
\hline $\mathrm{RS}$ & 10,3 & 11,1 & 1,1 & 0,5 & 0,0 & 0,0 & 0,0 & 7,6 & 24,8 & 1,7 & 1,3 & 0,3 & 0,0 & 0,0 & 15,9 & 19,2 & 3,3 & 3,0 & 0,0 & 0,1 & 0,0 & 100 \\
\hline $\mathrm{SC}$ & 0,0 & 0,0 & 0,0 & 1,0 & 0,0 & 0,0 & 0,0 & 1,0 & 8,4 & 1,2 & 0,7 & 0,0 & 0,0 & 0,0 & 45,5 & 13,8 & 7,1 & 18,9 & 0,0 & 2,5 & 0,0 & 100 \\
\hline Brasil & 13,9 & 10,4 & 1,9 & 4,4 & 0,0 & 0,1 & 0,1 & 21,9 & 7,7 & 2,4 & 4,1 & 0,1 & 0,0 & 0,2 & 20,3 & 5,9 & 2,2 & 4,0 & 0,0 & 0,2 & 0,1 & 100 \\
\hline
\end{tabular}

Fonte: resultados da pesquisa. 
Tabela 19. Crédito concedido por subprograma, região e APT em relação ao total do Brasil. Em porcentagem (\%)

\begin{tabular}{|c|c|c|c|c|c|c|c|c|c|c|c|c|c|c|c|c|c|c|c|c|c|c|c|c|c|}
\hline \multirow{2}{*}{ Região } & \multicolumn{8}{|c|}{ Apt. A } & \multicolumn{8}{|c|}{ Apt. B } & \multicolumn{8}{|c|}{ Apt. CD } & \multirow{2}{*}{ TOTAL } \\
\hline & RPD & SPD & iLPF & FLP & ARA & TDA & OUT & TOT. & RPD & SPD & iLPF & FLP & ARA & TDA & OUT & TOT. & RPD & SPD & iLPF & FLP & ARA & TDA & OUT & TOT. & \\
\hline Norte & 0,1 & 0,0 & 0,0 & 0,0 & 0,0 & 0,0 & 0,0 & 0,2 & 5,3 & 0,5 & 0,1 & 0,1 & 0,0 & 0,0 & 0,4 & 6,4 & 2,8 & 0,9 & 0,2 & 0,4 & 0,0 & 0,0 & 0,5 & 4,9 & 11,5 \\
\hline $\mathrm{AC}$ & 0,0 & 0,0 & 0,0 & 0,0 & 0,0 & 0,0 & 0,0 & 0,0 & 0,6 & 0,0 & 0,0 & 0,0 & 0,0 & 0,0 & 0,0 & 0,7 & 0,1 & 0,0 & 0,0 & 0,0 & 0,0 & 0,0 & 0,0 & 0,1 & 0,8 \\
\hline $\mathrm{AP}$ & 0,0 & 0,0 & 0,0 & 0,0 & 0,0 & 0,0 & 0,0 & 0,0 & 0,0 & 0,0 & 0,0 & 0,0 & 0,0 & 0,0 & 0,0 & 0,0 & 0,0 & 0,0 & 0,0 & 0,0 & 0,0 & 0,0 & 0,0 & 0,1 & 0,1 \\
\hline $\mathrm{PA}$ & 0,0 & 0,0 & 0,0 & 0,0 & 0,0 & 0,0 & 0,0 & 0,0 & 1,9 & 0,1 & 0,0 & 0,0 & 0,0 & 0,0 & 0,1 & 2,1 & 0,4 & 0,0 & 0,0 & 0,0 & 0,0 & 0,0 & 0,4 & 0,9 & 3,0 \\
\hline RO & 0,0 & 0,0 & 0,0 & 0,0 & 0,0 & 0,0 & 0,0 & 0,0 & 0,9 & 0,1 & 0,0 & 0,0 & 0,0 & 0,0 & 0,1 & 1,1 & 0,3 & 0,0 & 0,0 & 0,1 & 0,0 & 0,0 & 0,0 & 0,4 & 1,5 \\
\hline $\mathrm{RR}$ & 0,0 & 0,0 & 0,0 & 0,0 & 0,0 & 0,0 & 0,0 & 0,0 & 0,0 & 0,0 & 0,0 & 0,0 & 0,0 & 0,0 & 0,0 & 0,0 & 0,1 & 0,1 & 0,0 & 0,0 & 0,0 & 0,0 & 0,0 & 0,2 & 0,2 \\
\hline TO & 0,1 & 0,0 & 0,0 & 0,0 & 0,0 & 0,0 & 0,0 & 0,1 & 1,8 & 0,4 & 0,0 & 0,1 & 0,0 & 0,0 & 0,1 & 2,5 & 2,0 & 0,8 & 0,1 & 0,3 & 0,0 & 0,0 & 0,1 & 3,3 & 5,9 \\
\hline Nordeste & 0,4 & 2,7 & 0,2 & 0,2 & 0,0 & 0,0 & 0,0 & 3,5 & 0,5 & 0,2 & 0,1 & 0,2 & 0,0 & 0,0 & 0,0 & 1,0 & 2,3 & 2,4 & 0,1 & 0,1 & 0,0 & 0,0 & 0,0 & 5,0 & 9,5 \\
\hline BA & 0,4 & 2,7 & 0,2 & 0,2 & 0,0 & 0,0 & 0,0 & 3,5 & 0,4 & 0,1 & 0,1 & 0,2 & 0,0 & 0,0 & 0,0 & 0,8 & 0,8 & 0,9 & 0,1 & 0,1 & 0,0 & 0,0 & 0,0 & 1,8 & 6,1 \\
\hline MA & 0,0 & 0,0 & 0,0 & 0,0 & 0,0 & 0,0 & 0,0 & 0,0 & 0,1 & 0,0 & 0,0 & 0,0 & 0,0 & 0,0 & 0,0 & 0,1 & 1,3 & 0,7 & 0,0 & 0,1 & 0,0 & 0,0 & 0,0 & 2,1 & 2,3 \\
\hline $\mathrm{PE}$ & 0,0 & 0,0 & 0,0 & 0,0 & 0,0 & 0,0 & 0,0 & 0,0 & 0,0 & 0,0 & 0,0 & 0,0 & 0,0 & 0,0 & 0,0 & 0,0 & 0,1 & 0,0 & 0,0 & 0,0 & 0,0 & 0,0 & 0,0 & 0,1 & 0,1 \\
\hline PI & 0,0 & 0,0 & 0,0 & 0,0 & 0,0 & 0,0 & 0,0 & 0,0 & 0,0 & 0,1 & 0,0 & 0,0 & 0,0 & 0,0 & 0,0 & 0,1 & 0,1 & 0,8 & 0,0 & 0,0 & 0,0 & 0,0 & 0,0 & 0,9 & 1,0 \\
\hline Centro-Oeste & 4,3 & 4,0 & 0,5 & 1,0 & 0,0 & 0,0 & 0,2 & 10,0 & 10,5 & 3,9 & 1,1 & 1,0 & 0,0 & 0,0 & 0,1 & 16,5 & 6,0 & 0,8 & 0,8 & 2,4 & 0,0 & 0,0 & 0,0 & 10,1 & 36,5 \\
\hline GO & 1,7 & 1,9 & 0,1 & 0,4 & 0,0 & 0,0 & 0,0 & 4,1 & 5,8 & 1,7 & 0,7 & 0,3 & 0,0 & 0,0 & 0,0 & 8,6 & 1,8 & 0,2 & 0,1 & 0,2 & 0,0 & 0,0 & 0,0 & 2,4 & 15,1 \\
\hline MT & 0,3 & 0,8 & 0,0 & 0,1 & 0,0 & 0,0 & 0,0 & 1,2 & 3,4 & 2,0 & 0,3 & 0,3 & 0,0 & 0,0 & 0,1 & 6,0 & 2,1 & 0,4 & 0,4 & 0,1 & 0,0 & 0,0 & 0,0 & 3,0 & 10,2 \\
\hline MS & 2,3 & 1,3 & 0,3 & 0,5 & 0,0 & 0,0 & 0,1 & 4,6 & 1,3 & 0,1 & 0,1 & 0,4 & 0,0 & 0,0 & 0,0 & 1,8 & 2,1 & 0,2 & 0,3 & 2,1 & 0,0 & 0,0 & 0,0 & 4,7 & 11,1 \\
\hline Sudeste & 5,6 & 3,6 & 1,2 & 2,5 & 0,0 & 0,0 & 0,0 & 13,0 & 5,0 & 2,1 & 1,5 & 2,4 & 0,0 & 0,0 & 0,0 & 11,0 & 4,2 & 0,7 & 0,9 & 1,6 & 0,0 & 0,1 & 0,0 & 7,4 & 31,4 \\
\hline ES & 0,2 & 0,0 & 0,2 & 0,1 & 0,0 & 0,0 & 0,0 & 0,5 & 0,0 & 0,0 & 0,0 & 0,0 & 0,0 & 0,0 & 0,0 & 0,1 & 0,3 & 0,0 & 0,1 & 0,1 & 0,0 & 0,0 & 0,0 & 0,6 & 1,1 \\
\hline MG & 1,8 & 1,0 & 0,3 & 0,8 & 0,0 & 0,0 & 0,0 & 3,9 & 3,2 & 1,3 & 1,1 & 1,5 & 0,0 & 0,0 & 0,0 & 7,1 & 3,4 & 0,6 & 0,6 & 1,2 & 0,0 & 0,1 & 0,0 & 5,9 & 17,0 \\
\hline RJ & 0,0 & 0,0 & 0,0 & 0,0 & 0,0 & 0,0 & 0,0 & 0,0 & 0,0 & 0,0 & 0,0 & 0,0 & 0,0 & 0,0 & 0,0 & 0,0 & 0,2 & 0,0 & 0,0 & 0,0 & 0,0 & 0,0 & 0,0 & 0,3 & 0,3 \\
\hline SP & 3,6 & 2,6 & 0,7 & 1,6 & 0,0 & 0,0 & 0,0 & 8,6 & 1,7 & 0,7 & 0,4 & 0,9 & 0,0 & 0,0 & 0,0 & 3,8 & 0,2 & 0,1 & 0,1 & 0,3 & 0,0 & 0,0 & 0,0 & 0,7 & 13,0 \\
\hline Sul & 1,4 & 0,9 & 0,1 & 0,2 & 0,0 & 0,0 & 0,0 & 2,6 & 1,0 & 1,6 & 0,2 & 0,3 & 0,1 & 0,0 & 0,0 & 3,1 & 2,5 & 1,4 & 0,5 & 0,9 & 0,0 & 0,1 & 0,0 & 5,4 & 11,1 \\
\hline PR & 0,6 & 0,3 & 0,1 & 0,1 & 0,0 & 0,0 & 0,0 & 1,2 & 0,5 & 0,3 & 0,0 & 0,2 & 0,0 & 0,0 & 0,0 & 1,1 & 1,0 & 0,4 & 0,2 & 0,7 & 0,0 & 0,0 & 0,0 & 2,3 & 4,6 \\
\hline RS & 0,7 & 0,6 & 0,1 & 0,0 & 0,0 & 0,0 & 0,0 & 1,4 & 0,5 & 1,1 & 0,2 & 0,1 & 0,1 & 0,0 & 0,0 & 1,9 & 1,1 & 0,8 & 0,2 & 0,1 & 0,0 & 0,0 & 0,0 & 2,1 & 5,4 \\
\hline $\mathrm{SC}$ & 0,0 & 0,0 & 0,0 & 0,0 & 0,0 & 0,0 & 0,0 & 0,0 & 0,0 & 0,2 & 0,0 & 0,0 & 0,0 & 0,0 & 0,0 & 0,2 & 0,4 & 0,2 & 0,1 & 0,1 & 0,0 & 0,1 & 0,0 & 0,9 & 1,1 \\
\hline Brasil & 11,8 & 11,3 & 2,0 & 3,8 & 0,0 & 0,1 & 0,2 & 29,3 & 22,2 & 8,2 & 2,9 & 4,0 & 0,1 & 0,0 & 0,5 & 38,0 & 17,8 & 6,2 & 2,5 & 5,5 & 0,0 & 0,2 & 0,6 & 32,8 & 100,0 \\
\hline
\end{tabular}

Fonte: resultados da pesquisa. 
Tabela 20. Área por subprograma, região e APT em relação ao total do Brasil. Em porcentagem (\%)

\begin{tabular}{|c|c|c|c|c|c|c|c|c|c|c|c|c|c|c|c|c|c|c|c|c|c|c|c|c|c|}
\hline \multirow{2}{*}{ Região } & \multicolumn{8}{|c|}{ Apt. A } & \multicolumn{8}{|c|}{ Apt. B } & \multicolumn{8}{|c|}{ Apt. CD } & \multirow{2}{*}{ TOTAL } \\
\hline & RPD & SPD & iLPF & FLP & ARA & TDA & OUT & TOT. & RPD & SPD & iLPF & FLP & ARA & TDA & OUT & TOT. & RPD & SPD & iLPF & FLP & ARA & TDA & OUT & TOT. & \\
\hline Norte & 0,0 & 0,0 & 0,0 & 0,0 & 0,0 & 0,0 & 0,0 & 0,1 & 3,4 & 0,7 & 0,1 & 0,1 & 0,0 & 0,0 & 0,1 & 4,3 & 2,2 & 1,4 & 0,2 & 0,3 & 0,0 & 0,0 & 0,2 & 4,2 & 8,5 \\
\hline $\mathrm{AC}$ & 0,0 & 0,0 & 0,0 & 0,0 & 0,0 & 0,0 & 0,0 & 0,0 & 0,2 & 0,0 & 0,0 & 0,0 & 0,0 & 0,0 & 0,0 & 0,2 & 0,0 & 0,0 & 0,0 & 0,0 & 0,0 & 0,0 & 0,0 & 0,0 & 0,3 \\
\hline $\mathrm{AP}$ & 0,0 & 0,0 & 0,0 & 0,0 & 0,0 & 0,0 & 0,0 & 0,0 & 0,0 & 0,0 & 0,0 & 0,0 & 0,0 & 0,0 & 0,0 & 0,0 & 0,1 & 0,0 & 0,0 & 0,0 & 0,0 & 0,0 & 0,0 & 0,1 & 0,1 \\
\hline PA & 0,0 & 0,0 & 0,0 & 0,0 & 0,0 & 0,0 & 0,0 & 0,0 & 1,2 & 0,1 & 0,0 & 0,0 & 0,0 & 0,0 & 0,0 & 1,3 & 0,2 & 0,0 & 0,0 & 0,0 & 0,0 & 0,0 & 0,1 & 0,3 & 1,6 \\
\hline RO & 0,0 & 0,0 & 0,0 & 0,0 & 0,0 & 0,0 & 0,0 & 0,0 & 0,5 & 0,0 & 0,0 & 0,0 & 0,0 & 0,0 & 0,1 & 0,6 & 0,7 & 0,0 & 0,0 & 0,0 & 0,0 & 0,0 & 0,0 & 0,7 & 1,3 \\
\hline $\mathrm{RR}$ & 0,0 & 0,0 & 0,0 & 0,0 & 0,0 & 0,0 & 0,0 & 0,0 & 0,0 & 0,0 & 0,0 & 0,0 & 0,0 & 0,0 & 0,0 & 0,0 & 0,0 & 0,3 & 0,0 & 0,0 & 0,0 & 0,0 & 0,0 & 0,3 & 0,3 \\
\hline TO & 0,0 & 0,0 & 0,0 & 0,0 & 0,0 & 0,0 & 0,0 & 0,0 & 1,4 & 0,6 & 0,1 & 0,0 & 0,0 & 0,0 & 0,0 & 2,1 & 1,2 & 1,1 & 0,1 & 0,3 & 0,0 & 0,0 & 0,0 & 2,6 & 4,8 \\
\hline Nordeste & 0,3 & 3,7 & 0,1 & 0,1 & 0,0 & 0,0 & 0,0 & 4,1 & 0,3 & 0,3 & 0,0 & 0,0 & 0,0 & 0,0 & 0,0 & 0,6 & 1,2 & 3,5 & 0,1 & 0,1 & 0,0 & 0,0 & 0,0 & 4,8 & 9,5 \\
\hline $\mathrm{BA}$ & 0,3 & 3,7 & 0,1 & 0,1 & 0,0 & 0,0 & 0,0 & 4,1 & 0,2 & 0,2 & 0,0 & 0,0 & 0,0 & 0,0 & 0,0 & 0,5 & 0,4 & 1,1 & 0,0 & 0,0 & 0,0 & 0,0 & 0,0 & 1,6 & 6,2 \\
\hline MA & 0,0 & 0,0 & 0,0 & 0,0 & 0,0 & 0,0 & 0,0 & 0,0 & 0,0 & 0,0 & 0,0 & 0,0 & 0,0 & 0,0 & 0,0 & 0,0 & 0,6 & 1,1 & 0,0 & 0,1 & 0,0 & 0,0 & 0,0 & 1,9 & 1,9 \\
\hline $\mathrm{PE}$ & 0,0 & 0,0 & 0,0 & 0,0 & 0,0 & 0,0 & 0,0 & 0,0 & 0,0 & 0,0 & 0,0 & 0,0 & 0,0 & 0,0 & 0,0 & 0,0 & 0,0 & 0,0 & 0,0 & 0,0 & 0,0 & 0,0 & 0,0 & 0,0 & 0,0 \\
\hline PI & 0,0 & 0,0 & 0,0 & 0,0 & 0,0 & 0,0 & 0,0 & 0,0 & 0,0 & 0,1 & 0,0 & 0,0 & 0,0 & 0,0 & 0,0 & 0,1 & 0,0 & 1,2 & 0,0 & 0,0 & 0,0 & 0,0 & 0,0 & 1,3 & 1,4 \\
\hline Centro-Oeste & 2,8 & 5,0 & 0,3 & 0,5 & 0,0 & 0,0 & 0,2 & 8,7 & 7,8 & 4,8 & 18,1 & 0,4 & 0,0 & 0,0 & 0,2 & 31,3 & 4,4 & 1,0 & 0,5 & 0,9 & 0,0 & 0,0 & 0,0 & 6,9 & 47,0 \\
\hline $\mathrm{GO}$ & 1,2 & 2,0 & 0,1 & 0,2 & 0,0 & 0,0 & 0,0 & 3,4 & 4,7 & 1,7 & 17,9 & 0,1 & 0,0 & 0,0 & 0,0 & 24,4 & 1,4 & 0,3 & 0,0 & 0,1 & 0,0 & 0,0 & 0,0 & 1,8 & 29,6 \\
\hline MT & 0,2 & 1,5 & 0,0 & 0,1 & 0,0 & 0,0 & 0,1 & 1,9 & 2,2 & 3,0 & 0,2 & 0,2 & 0,0 & 0,0 & 0,2 & 5,7 & 1,5 & 0,7 & 0,3 & 0,0 & 0,0 & 0,0 & 0,0 & 2,5 & 10,1 \\
\hline MS & 1,5 & 1,4 & 0,2 & 0,3 & 0,0 & 0,0 & 0,0 & 3,4 & 0,9 & 0,1 & 0,0 & 0,1 & 0,0 & 0,0 & 0,0 & 1,1 & 1,4 & 0,1 & 0,2 & 0,8 & 0,0 & 0,0 & 0,0 & 2,6 & 7,2 \\
\hline Sudeste & 2,4 & 1,4 & 0,3 & 1,2 & 0,0 & 0,0 & 0,0 & 5,3 & 2,1 & 1,6 & 0,4 & 1,0 & 0,1 & 0,0 & 0,0 & 5,1 & 2,3 & 0,4 & 0,2 & 0,6 & 0,0 & 0,0 & 0,0 & 3,6 & 14,0 \\
\hline ES & 0,1 & 0,0 & 0,0 & 0,0 & 0,0 & 0,0 & 0,0 & 0,2 & 0,0 & 0,0 & 0,0 & 0,0 & 0,0 & 0,0 & 0,0 & 0,0 & 0,1 & 0,0 & 0,0 & 0,0 & 0,0 & 0,0 & 0,0 & 0,2 & 0,4 \\
\hline $\mathrm{MG}$ & 0,9 & 0,5 & 0,1 & 0,3 & 0,0 & 0,0 & 0,0 & 1,8 & 1,4 & 1,4 & 0,3 & 0,6 & 0,1 & 0,0 & 0,0 & 3,7 & 2,1 & 0,4 & 0,2 & 0,5 & 0,0 & 0,0 & 0,0 & 3,2 & 8,7 \\
\hline $\mathrm{RJ}$ & 0,0 & 0,0 & 0,0 & 0,0 & 0,0 & 0,0 & 0,0 & 0,0 & 0,0 & 0,0 & 0,0 & 0,0 & 0,0 & 0,0 & 0,0 & 0,0 & 0,1 & 0,0 & 0,0 & 0,0 & 0,0 & 0,0 & 0,0 & 0,1 & 0,1 \\
\hline SP & 1,5 & 0,9 & 0,2 & 0,8 & 0,0 & 0,0 & 0,0 & 3,4 & 0,7 & 0,2 & 0,1 & 0,4 & 0,0 & 0,0 & 0,0 & 1,4 & 0,1 & 0,0 & 0,0 & 0,1 & 0,0 & 0,0 & 0,0 & 0,2 & 4,9 \\
\hline Sul & 0,9 & 1,9 & 4,1 & 0,1 & 0,0 & 0,0 & 0,0 & 7,0 & 0,7 & 2,9 & 0,2 & 0,1 & 0,0 & 0,0 & 0,0 & 4,0 & 1,7 & 2,4 & 0,3 & 5,5 & 0,0 & 0,0 & 0,0 & 9,9 & 20,9 \\
\hline PR & 0,3 & 0,6 & 0,0 & 0,0 & 0,0 & 0,0 & 0,0 & 0,9 & 0,1 & 0,4 & 0,0 & 0,1 & 0,0 & 0,0 & 0,0 & 0,7 & 0,5 & 0,6 & 0,2 & 5,4 & 0,0 & 0,0 & 0,0 & 6,7 & 8,3 \\
\hline RS & 0,6 & 1,3 & 4,1 & 0,0 & 0,0 & 0,0 & 0,0 & 6,1 & 0,6 & 2,4 & 0,2 & 0,0 & 0,0 & 0,0 & 0,0 & 3,2 & 0,8 & 1,6 & 0,1 & 0,0 & 0,0 & 0,0 & 0,0 & 2,5 & 11,8 \\
\hline $\mathrm{SC}$ & 0,0 & 0,0 & 0,0 & 0,0 & 0,0 & 0,0 & 0,0 & 0,0 & 0,0 & 0,1 & 0,0 & 0,0 & 0,0 & 0,0 & 0,0 & 0,2 & 0,4 & 0,2 & 0,0 & 0,0 & 0,0 & 0,0 & 0,0 & 0,6 & 0,8 \\
\hline Brasil & 6,5 & 12,0 & 4,8 & 1,8 & 0,0 & 0,0 & 0,2 & 25,2 & 14,2 & 10,2 & 18,9 & 1,6 & 0,1 & 0,0 & 0,3 & 45,3 & 11,8 & 8,7 & 1,3 & 7,4 & 0,0 & 0,0 & 0,2 & 29,4 & 100,0 \\
\hline
\end{tabular}

Fonte: resultados da pesquisa. 
Tabela 21. Contratos por subprograma, região e APT em relação ao total do Brasil. Em porcentagem (\%)

\begin{tabular}{|c|c|c|c|c|c|c|c|c|c|c|c|c|c|c|c|c|c|c|c|c|c|c|c|c|c|}
\hline \multirow{2}{*}{ Região } & \multicolumn{8}{|c|}{ Apt. A } & \multicolumn{8}{|c|}{ Apt. B } & \multicolumn{8}{|c|}{ Apt. CD } & \multirow{2}{*}{ TOTAL } \\
\hline & RPD & SPD & iLPF & FLP & ARA & TDA & OUT & TOT. & RPD & $\begin{array}{l}\text { SPD } \\
\end{array}$ & iLPF & FLP & ARA & TDA & OUT & TOT. & RPD & SPD & iLPF & FLP & ARA & TDA & OUT & TOT. & \\
\hline Norte & 0,1 & 0,0 & 0,0 & 0,0 & 0,0 & 0,0 & 0,0 & 0,1 & 4,5 & 0,4 & 0,1 & 0,1 & 0,0 & 0,0 & 0,1 & 5,3 & 2,8 & 0,8 & 0,2 & 0,2 & 0,0 & 0,0 & 0,1 & 4,1 & 9,5 \\
\hline $\mathrm{AC}$ & 0,0 & 0,0 & 0,0 & 0,0 & 0,0 & 0,0 & 0,0 & 0,0 & 0,7 & 0,0 & 0,0 & 0,0 & 0,0 & 0,0 & 0,0 & 0,8 & 0,0 & 0,0 & 0,0 & 0,0 & 0,0 & 0,0 & 0,0 & 0,0 & 0,8 \\
\hline $\mathrm{AP}$ & 0,0 & 0,0 & 0,0 & 0,0 & 0,0 & 0,0 & 0,0 & 0,0 & 0,0 & 0,0 & 0,0 & 0,0 & 0,0 & 0,0 & 0,0 & 0,0 & 0,0 & 0,0 & 0,0 & 0,0 & 0,0 & 0,0 & 0,0 & 0,1 & 0,1 \\
\hline PA & 0,0 & 0,0 & 0,0 & 0,0 & 0,0 & 0,0 & 0,0 & 0,0 & 1,2 & 0,0 & 0,0 & 0,0 & 0,0 & 0,0 & 0,0 & 1,3 & 0,3 & 0,0 & 0,0 & 0,0 & 0,0 & 0,0 & 0,0 & 0,4 & 1,7 \\
\hline RO & 0,1 & 0,0 & 0,0 & 0,0 & 0,0 & 0,0 & 0,0 & 0,1 & 0,8 & 0,0 & 0,0 & 0,0 & 0,0 & 0,0 & 0,0 & 0,9 & 0,3 & 0,0 & 0,0 & 0,0 & 0,0 & 0,0 & 0,0 & 0,3 & 1,3 \\
\hline $\mathrm{RR}$ & 0,0 & 0,0 & 0,0 & 0,0 & 0,0 & 0,0 & 0,0 & 0,0 & 0,0 & 0,0 & 0,0 & 0,0 & 0,0 & 0,0 & 0,0 & 0,0 & 0,1 & 0,0 & 0,0 & 0,0 & 0,0 & 0,0 & 0,0 & 0,1 & 0,1 \\
\hline TO & 0,1 & 0,0 & 0,0 & 0,0 & 0,0 & 0,0 & 0,0 & 0,1 & 1,8 & 0,3 & 0,0 & 0,1 & 0,0 & 0,0 & 0,0 & 2,3 & 2,1 & 0,7 & 0,1 & 0,2 & 0,0 & 0,0 & 0,0 & 3,2 & 5,6 \\
\hline Nordeste & 0,4 & 1,7 & 0,1 & 0,1 & 0,0 & 0,0 & 0,0 & 2,3 & 0,5 & 0,2 & 0,1 & 0,2 & 0,0 & 0,0 & 0,0 & 0,9 & 2,7 & 1,4 & 0,1 & 0,1 & 0,0 & 0,0 & 0,0 & 4,3 & 7,5 \\
\hline BA & 0,3 & 1,7 & 0,1 & 0,1 & 0,0 & 0,0 & 0,0 & 2,2 & 0,4 & 0,1 & 0,1 & 0,2 & 0,0 & 0,0 & 0,0 & 0,8 & 0,7 & 0,4 & 0,1 & 0,1 & 0,0 & 0,0 & 0,0 & 1,3 & 4,3 \\
\hline MA & 0,0 & 0,0 & 0,0 & 0,0 & 0,0 & 0,0 & 0,0 & 0,0 & 0,0 & 0,0 & 0,0 & 0,0 & 0,0 & 0,0 & 0,0 & 0,1 & 1,7 & 0,5 & 0,0 & 0,1 & 0,0 & 0,0 & 0,0 & 2,3 & 2,4 \\
\hline $\mathrm{PE}$ & 0,0 & 0,0 & 0,0 & 0,0 & 0,0 & 0,0 & 0,0 & 0,0 & 0,0 & 0,0 & 0,0 & 0,0 & 0,0 & 0,0 & 0,0 & 0,0 & 0,1 & 0,0 & 0,0 & 0,0 & 0,0 & 0,0 & 0,0 & 0,2 & 0,2 \\
\hline PI & 0,0 & 0,0 & 0,0 & 0,0 & 0,0 & 0,0 & 0,0 & 0,0 & 0,0 & 0,0 & 0,0 & 0,0 & 0,0 & 0,0 & 0,0 & 0,0 & 0,1 & 0,5 & 0,0 & 0,0 & 0,0 & 0,0 & 0,0 & 0,5 & 0,6 \\
\hline Centro-Oeste & 4,2 & 2,7 & 0,2 & 0,6 & 0,0 & 0,0 & 0,1 & 7,8 & 9,4 & 2,7 & 0,5 & 0,6 & 0,0 & 0,0 & 0,1 & 13,4 & 4,9 & 0,6 & 0,2 & 0,3 & 0,0 & 0,0 & 0,0 & 6,1 & 27,2 \\
\hline GO & 2,0 & 1,3 & 0,1 & 0,2 & 0,0 & 0,0 & 0,0 & 3,6 & 6,2 & 1,4 & 0,4 & 0,3 & 0,0 & 0,0 & 0,0 & 8,3 & 2,0 & 0,3 & 0,1 & 0,2 & 0,0 & 0,0 & 0,0 & 2,6 & 14,6 \\
\hline MT & 0,1 & 0,5 & 0,0 & 0,0 & 0,0 & 0,0 & 0,0 & 0,6 & 2,1 & 1,2 & 0,1 & 0,2 & 0,0 & 0,0 & 0,0 & 3,6 & 1,3 & 0,2 & 0,1 & 0,0 & 0,0 & 0,0 & 0,0 & 1,6 & 5,8 \\
\hline MS & 2,1 & 1,0 & 0,1 & 0,3 & 0,0 & 0,0 & 0,1 & 3,5 & 1,1 & 0,1 & 0,0 & 0,1 & 0,0 & 0,0 & 0,0 & 1,4 & 1,5 & 0,1 & 0,1 & 0,1 & 0,0 & 0,0 & 0,0 & 1,9 & 6,8 \\
\hline Sudeste & 7,8 & 4,2 & 1,4 & 3,3 & 0,0 & 0,0 & 0,0 & 16,8 & 6,2 & 1,9 & 1,5 & 2,9 & 0,0 & 0,0 & 0,0 & 12,6 & 6,6 & 0,5 & 1,1 & 2,0 & 0,0 & 0,1 & 0,0 & 10,2 & 39,6 \\
\hline ES & 0,2 & 0,0 & 0,2 & 0,1 & 0,0 & 0,0 & 0,0 & 0,4 & 0,0 & 0,0 & 0,0 & 0,0 & 0,0 & 0,0 & 0,0 & 0,0 & 0,4 & 0,0 & 0,3 & 0,1 & 0,0 & 0,0 & 0,0 & 0,9 & 1,4 \\
\hline MG & 2,4 & 0,8 & 0,3 & 0,7 & 0,0 & 0,0 & 0,0 & 4,2 & 3,4 & 1,1 & 0,9 & 1,3 & 0,0 & 0,0 & 0,0 & 6,7 & 5,4 & 0,4 & 0,6 & 1,3 & 0,0 & 0,1 & 0,0 & 7,7 & 18,7 \\
\hline $\mathrm{RJ}$ & 0,0 & 0,0 & 0,0 & 0,0 & 0,0 & 0,0 & 0,0 & 0,0 & 0,0 & 0,0 & 0,0 & 0,0 & 0,0 & 0,0 & 0,0 & 0,0 & 0,3 & 0,0 & 0,0 & 0,0 & 0,0 & 0,0 & 0,0 & 0,4 & 0,4 \\
\hline SP & 5,2 & 3,4 & 1,0 & 2,5 & 0,0 & 0,0 & 0,0 & 12,1 & 2,7 & 0,9 & 0,6 & 1,5 & 0,0 & 0,0 & 0,0 & 5,8 & 0,4 & 0,1 & 0,2 & 0,5 & 0,0 & 0,0 & 0,0 & 1,2 & 19,1 \\
\hline Sul & 1,5 & 1,8 & 0,1 & 0,4 & 0,0 & 0,0 & 0,0 & 3,8 & 1,3 & 2,5 & 0,2 & 0,4 & 0,0 & 0,0 & 0,0 & 4,4 & 3,4 & 2,6 & 0,6 & 1,3 & 0,0 & 0,1 & 0,0 & 8,0 & 16,2 \\
\hline PR & 0,7 & 1,0 & 0,0 & 0,3 & 0,0 & 0,0 & 0,0 & 2,1 & 0,7 & 0,5 & 0,1 & 0,3 & 0,0 & 0,0 & 0,0 & 1,6 & 1,3 & 0,9 & 0,2 & 0,7 & 0,0 & 0,0 & 0,0 & 3,2 & 6,9 \\
\hline RS & 0,8 & 0,8 & 0,1 & 0,0 & 0,0 & 0,0 & 0,0 & 1,7 & 0,6 & 1,8 & 0,1 & 0,1 & 0,0 & 0,0 & 0,0 & 2,6 & 1,2 & 1,4 & 0,2 & 0,2 & 0,0 & 0,0 & 0,0 & 3,0 & 7,3 \\
\hline $\mathrm{SC}$ & 0,0 & 0,0 & 0,0 & 0,0 & 0,0 & 0,0 & 0,0 & 0,0 & 0,0 & 0,2 & 0,0 & 0,0 & 0,0 & 0,0 & 0,0 & 0,2 & 0,9 & 0,3 & 0,1 & 0,4 & 0,0 & 0,0 & 0,0 & 1,7 & 2,0 \\
\hline Brasil & 13,9 & 10,4 & 1,9 & 4,4 & 0,0 & 0,1 & 0,1 & 30,8 & 21,9 & 7,7 & 2,4 & 4,1 & 0,1 & 0,0 & 0,2 & 36,5 & 20,3 & 5,9 & 2,2 & 4,0 & 0,0 & 0,2 & 0,1 & 32,8 & 100,0 \\
\hline
\end{tabular}

Fonte: resultados da pesquisa. 
Tabela 22. Valores médios dos contratos por subprogramas, regiões e APT. Em mil reais.

\begin{tabular}{|c|c|c|c|c|c|c|c|c|c|c|c|c|c|c|c|c|c|c|c|c|c|}
\hline \multirow{2}{*}{ Região } & \multicolumn{7}{|c|}{ Apt. A } & \multicolumn{7}{|c|}{ Apt. B } & \multicolumn{7}{|c|}{ Apt. CD } \\
\hline & RPD & SPD & iLPF & FLP & ARA & TDA & OUT & RPD & SPD & iLPF & FLP & ARA & TDA & OUT & RPD & SPD & iLPF & FLP & ARA & TDA & OUT \\
\hline Norte & 438,8 & 0,0 & 0,0 & 573,3 & 0,0 & $1.132,2$ & 984,1 & 558,0 & 604,6 & 644,1 & 659,2 & 495,8 & 0,0 & $1.231,8$ & 474,8 & 566,1 & 604,8 & 781,3 & 0,0 & 0,0 & $2.352,2$ \\
\hline $\mathrm{AC}$ & 0,0 & 0,0 & 0,0 & 0,0 & 0,0 & 0,0 & 0,0 & 442,2 & 0,0 & 545,1 & 0,0 & 0,0 & 0,0 & 255,4 & 797,0 & 0,0 & 0,0 & 0,0 & 0,0 & 0,0 & 553,0 \\
\hline $\mathrm{AP}$ & 0,0 & 0,0 & 0,0 & 0,0 & 0,0 & 0,0 & 0,0 & 0,0 & 0,0 & 0,0 & 0,0 & 0,0 & 0,0 & 0,0 & 671,2 & 348,8 & 0,0 & 0,0 & 0,0 & 0,0 & 0,0 \\
\hline $\mathrm{PA}$ & 0,0 & 0,0 & 0,0 & 0,0 & 0,0 & 0,0 & 0,0 & 776,0 & 560,3 & $1.299,2$ & 244,3 & 0,0 & 0,0 & $2.073,3$ & 598,3 & 761,9 & 488,3 & $1.000,0$ & 0,0 & 0,0 & $5.014,9$ \\
\hline RO & 385,4 & 0,0 & 0,0 & 0,0 & 0,0 & 0,0 & 0,0 & 545,3 & 886,5 & 0,0 & 551,8 & 495,8 & 0,0 & $1.329,3$ & 449,8 & 0,0 & 799,9 & $4.992,3$ & 0,0 & 0,0 & 843,1 \\
\hline $\mathrm{RR}$ & 0,0 & 0,0 & 0,0 & 0,0 & 0,0 & 0,0 & 0,0 & 0,0 & 0,0 & 0,0 & 0,0 & 0,0 & 0,0 & 0,0 & 724,0 & $1.071,1$ & $1.147,1$ & 0,0 & 0,0 & 0,0 & 0,0 \\
\hline TO & 487,8 & 0,0 & 0,0 & 573,3 & 0,0 & $1.132,2$ & 984,1 & 467,7 & 586,4 & 499,4 & 743,2 & 0,0 & 0,0 & $1.613,7$ & 444,6 & 551,7 & 525,6 & 684,5 & 0,0 & 0,0 & 854,7 \\
\hline Nordeste & 526,3 & 782,4 & 882,7 & 614,7 & 0,0 & 0,0 & $2.000,0$ & 501,0 & 582,9 & 650,7 & 540,0 & 0,0 & 0,0 & 0,0 & 420,3 & 799,3 & 545,7 & 497,7 & 0,0 & 0,0 & 344,0 \\
\hline $\mathrm{BA}$ & 532,5 & 782,4 & 882,7 & 614,7 & 0,0 & 0,0 & $2.000,0$ & 475,4 & 542,8 & 641,9 & 540,0 & 0,0 & 0,0 & 0,0 & 523,6 & 944,8 & 545,3 & 568,3 & 0,0 & 0,0 & 344,0 \\
\hline MA & 477,5 & 0,0 & 0,0 & 0,0 & 0,0 & 0,0 & 0,0 & 865,6 & 264,1 & 790,1 & 0,0 & 0,0 & 0,0 & 0,0 & 377,5 & 629,9 & 657,8 & 446,1 & 0,0 & 0,0 & 0,0 \\
\hline PE & 0,0 & 0,0 & 0,0 & 0,0 & 0,0 & 0,0 & 0,0 & 249,9 & 0,0 & 0,0 & 0,0 & 0,0 & 0,0 & 0,0 & 242,2 & 0,0 & 357,0 & 54,8 & 0,0 & 0,0 & 0,0 \\
\hline PI & 0,0 & 0,0 & 0,0 & 0,0 & 0,0 & 0,0 & 0,0 & 0,0 & 725,2 & 0,0 & 0,0 & 0,0 & 0,0 & 0,0 & 730,2 & 853,1 & 520,0 & 665,9 & 0,0 & 0,0 & 0,0 \\
\hline Centro-Oeste & 485,1 & 715,9 & 985,5 & 835,6 & 378,5 & $1.199,5$ & $1.163,4$ & 529,8 & 672,6 & 924,6 & 798,6 & 136,3 & 382,0 & 654,0 & 587,0 & 627,9 & $1.584,1$ & $3.348,7$ & 0,0 & 0,0 & 659,8 \\
\hline GO & 411,5 & 715,4 & 570,9 & 761,1 & 378,5 & 0,0 & 91,0 & 448,0 & 571,5 & 925,9 & 571,6 & 33,4 & 0,0 & 229,2 & 421,9 & 364,1 & 501,4 & 543,1 & 0,0 & 0,0 & 0,0 \\
\hline MT & 983,8 & 821,8 & 066,5 & $2.199,7$ & 0,0 & 0,0 & 112,7 & 767,1 & 810,9 & $1.010,3$ & 654,0 & 239,1 & 201,2 & $2.069,9$ & 786,3 & $1.097,3$ & $2.781,0$ & 955,6 & 0,0 & 0,0 & 962,3 \\
\hline MS & 525,6 & 672,9 & $1.448,3$ & 808,5 & 0,0 & 0,0 & $1.088,2$ & 534,6 & 489,8 & 700,4 & $1.472,8$ & 0,0 & 562,9 & 0,0 & 640,7 & 592,8 & $2.207,0$ & $7.768,0$ & 0,0 & 0,0 & 357,3 \\
\hline Sudeste & 343,4 & 407,6 & 419,5 & 352,9 & 98,4 & 690,2 & 0,0 & 383,0 & 510,2 & 462,3 & 399,0 & 64,4 & 560,3 & 0,0 & 303,8 & 650,7 & 383,2 & 382,0 & 117,5 & 447,4 & 183,6 \\
\hline ES & 602,0 & 675,3 & 549,6 & 279,7 & 0,0 & 0,0 & 0,0 & 953,0 & 0,0 & 207,7 & 0,0 & 0,0 & 0,0 & 0,0 & 382,6 & 423,2 & 255,0 & 228,6 & 0,0 & 228,6 & 183,6 \\
\hline MG & 359,4 & 568,1 & 531,4 & 534,2 & 0,0 & $1.105,8$ & 0,0 & 453,4 & 597,4 & 569,0 & 529,5 & 64,4 & 574,2 & 0,0 & 302,7 & 767,5 & 454,4 & 445,2 & 90,0 & 511,1 & 0,0 \\
\hline RJ & 102,9 & 0,0 & 620,0 & 795,0 & 0,0 & 0,0 & 0,0 & 0,0 & 0,0 & 0,0 & 0,0 & 0,0 & 0,0 & 0,0 & 316,2 & 15,2 & 476,1 & 439,1 & 0,0 & 381,9 & 0,0 \\
\hline SP & 328,8 & 367,8 & 362,4 & 303,9 & 98,4 & 274,7 & 0,0 & 291,2 & 402,7 & 320,0 & 286,6 & 0,0 & 518,7 & 0,0 & 227,9 & 274,4 & 324,5 & 268,8 & 144,9 & 31,1 & 0,0 \\
\hline Sul & 445,6 & 242,8 & 471,9 & 228,8 & 0,0 & 620,6 & 0,0 & 374,2 & 302,5 & 454,1 & 348,3 & 903,7 & 0,0 & 0,0 & 348,9 & 251,6 & 389,2 & 331,4 & 295,3 & 569,2 & 0,0 \\
\hline PR & 431,4 & 165,6 & 587,3 & 191,8 & 0,0 & 620,6 & 0,0 & 350,8 & 253,0 & 278,5 & 359,5 & 557,4 & 0,0 & 0,0 & 361,9 & 215,8 & 401,2 & 456,5 & 295,3 & 438,0 & 0,0 \\
\hline RS & 459,0 & 337,0 & 399,8 & 446,7 & 0,0 & 0,0 & 0,0 & 402,8 & 300,1 & 604,8 & 355,5 & $1.250,0$ & 0,0 & 0,0 & 428,1 & 257,3 & 411,0 & 194,5 & 0,0 & 324,6 & 0,0 \\
\hline $\mathrm{SC}$ & 0,0 & 0,0 & 0,0 & 503,3 & 0,0 & 0,0 & 0,0 & 375,5 & 480,2 & 157,5 & 75,9 & 0,0 & 0,0 & 0,0 & 226,6 & 339,1 & 333,9 & 169,3 & 0,0 & 709,9 & 0,0 \\
\hline Brasil & 402,5 & 518,1 & 520,3 & 411,9 & 238,5 & 734,7 & $1.191,5$ & 484,7 & 507,4 & 576,6 & 461,2 & 625,1 & 500,9 & $1.057,1$ & 418,2 & 499,3 & 544,7 & 647,2 & 206,4 & 517,5 & $1.961,3$ \\
\hline
\end{tabular}

Fonte: resultados da pesquisa. 
Tabela 23. Valores médios por hectare dos contratos por subprogramas, regiões e APT. Em reais.

\begin{tabular}{|c|c|c|c|c|c|c|c|c|c|c|c|c|c|c|c|c|c|c|c|c|c|}
\hline \multirow{2}{*}{ Região } & \multicolumn{7}{|c|}{ Apt. A } & \multicolumn{7}{|c|}{ Apt. B } & \multicolumn{7}{|c|}{ Apt. CD } \\
\hline & RPD & SPD & iLPF & FLP & ARA & TDA & OUT & RPD & SPD & iLPF & FLP & ARA & TDA & OUT & RPD & SPD & iLPF & FLP & ARA & TDA & OUT \\
\hline Norte & 4.055 & 0 & 0 & 4.047 & 0 & 0 & 17.308 & 2.753 & 1.389 & 1.356 & 4.078 & 2.929 & 0 & 7.949 & 2.268 & 1.182 & 1.750 & 2.624 & 0 & 0 & 5.648 \\
\hline $\mathrm{AC}$ & 0 & 0 & 0 & 0 & 0 & 0 & 0 & 4.960 & 0 & 3.785 & 0 & 0 & 0 & 3.774 & 3.799 & 0 & 0 & 0 & 0 & 0 & 2.304 \\
\hline $\mathrm{AP}$ & 0 & 0 & 0 & 0 & 0 & 0 & 0 & 0 & 0 & 0 & 0 & 0 & 0 & 0 & 855 & 1.297 & 0 & 0 & 0 & 0 & 0 \\
\hline $\mathrm{PA}$ & 0 & 0 & 0 & 0 & 0 & 0 & 0 & 2.737 & 1.339 & 2.787 & 2.305 & 0 & 0 & 35.141 & 3.445 & 4.816 & 7.342 & 4.144 & 0 & 0 & 5.769 \\
\hline RO & 3.775 & 0 & 0 & 0 & 0 & 0 & 0 & 3.266 & 73.868 & 0 & 4.686 & 2.929 & 0 & 3.002 & 695 & 0 & 3.225 & 9.997 & 0 & 0 & 4.215 \\
\hline $\mathrm{RR}$ & 0 & 0 & 0 & 0 & 0 & 0 & 0 & 0 & 0 & 0 & 0 & 0 & 0 & 0 & 4.438 & 438 & 1.884 & 0 & 0 & 0 & 0 \\
\hline TO & 4.285 & 0 & 0 & 4.047 & 0 & 0 & 17.308 & 2.225 & 1.239 & 807 & 4.111 & 0 & 0 & 22.030 & 2.976 & 1.312 & 1.492 & 2.313 & 0 & 0 & 6.248 \\
\hline Nordeste & 2.232 & 1.289 & 6.138 & 3.620 & 0 & 0 & 2.000 .000 & 3.090 & 1.284 & 5.774 & 7.691 & 0 & 0 & 0 & 3.514 & 1.199 & 4.341 & 1.855 & 0 & 0 & 6.735 \\
\hline $\mathrm{BA}$ & 2.069 & 1.289 & 6.138 & 3.620 & 0 & 0 & 2.000 .000 & 2.895 & 1.252 & 5.850 & 7.691 & 0 & 0 & 0 & 3.220 & 1.390 & 3.276 & 4.086 & 0 & 0 & 6.735 \\
\hline MA & 7.255 & 0 & 0 & 0 & 0 & 0 & 0 & 4.408 & 0 & 4.938 & 0 & 0 & 0 & 0 & 3.589 & 1.058 & 5.505 & 1.241 & 0 & 0 & 0 \\
\hline $\mathrm{PE}$ & 0 & 0 & 0 & 0 & 0 & 0 & 0 & 0 & 0 & 0 & 0 & 0 & 0 & 0 & 4.092 & 0 & 6.375 & 0 & 0 & 0 & 0 \\
\hline PI & 0 & 0 & 0 & 0 & 0 & 0 & 0 & 0 & 1.299 & 0 & 0 & 0 & 0 & 0 & 4.405 & 1.161 & 0 & 1.279 & 0 & 0 & 0 \\
\hline Centro-Oeste & 2.613 & 1.402 & 3.223 & 3.616 & 5.260 & 0 & 1.921 & 2.354 & 1.396 & 102 & 4.122 & 3.376 & 0 & 742 & 2.380 & 1.371 & 2.617 & 4.539 & 0 & 0 & 1.352 \\
\hline GO & 2.581 & 1.620 & 3.001 & 4.346 & 5.260 & 0 & 0 & 2.157 & 1.756 & 72 & 6.057 & 557 & 0 & 1.283 & 2.184 & 1.651 & 5.966 & 4.935 & 0 & 0 & 0 \\
\hline MT & 2.844 & 875 & 3.073 & 2.795 & 0 & 0 & 732 & 2.765 & 1.177 & 2.144 & 2.079 & 11.524 & 0 & 642 & 2.444 & 1.120 & 2.126 & 6.550 & 0 & 0 & 1.205 \\
\hline MS & 2.615 & 1.677 & 3.330 & 3.368 & 0 & 0 & 4.425 & 2.400 & 1.752 & 8.985 & 6.700 & 0 & 0 & 0 & 2.509 & 2.073 & 2.775 & 4.445 & 0 & 0 & 2.007 \\
\hline Sudeste & 3.995 & 4.565 & 7.099 & 3.672 & 5.966 & 0 & 0 & 4.165 & 2.282 & 6.456 & 4.291 & 26 & 0 & 0 & 3.148 & 2.898 & 6.192 & 4.483 & 6.289 & 19.572 & 6.120 \\
\hline ES & 3.739 & 2.101 & 9.312 & 5.721 & 0 & 0 & 0 & 2.227 & 0 & 11.758 & 0 & 0 & 0 & 0 & 3.961 & 12.090 & 11.366 & 6.872 & 0 & 0 & 6.120 \\
\hline MG & 3.764 & 3.446 & 5.441 & 4.096 & 0 & 0 & 0 & 4.126 & 1.722 & 5.797 & 4.403 & 26 & 0 & 0 & 2.908 & 2.665 & 5.285 & 3.985 & 9.000 & 19.318 & 0 \\
\hline $\mathrm{RJ}$ & 5.512 & 0 & 10.333 & 27.414 & 0 & 0 & 0 & 0 & 0 & 0 & 0 & 0 & 0 & 0 & 6.784 & 0 & 7.936 & 14.395 & 0 & 13.168 & 0 \\
\hline SP & 4.140 & 5.246 & 7.476 & 3.440 & 5.966 & 0 & 0 & 4.354 & 5.639 & 8.896 & 4.123 & 0 & 0 & 0 & 5.970 & 6.400 & 8.852 & 6.597 & 5.298 & 0 & 0 \\
\hline Sul & 2.747 & 826 & 53 & 4.806 & 0 & 0 & 0 & 2.378 & 945 & 1.413 & 3.577 & 16.512 & 0 & 0 & 2.513 & 975 & 2.908 & 291 & 9.842 & 0 & 0 \\
\hline PR & 4.078 & 1.009 & 8.051 & 5.367 & 0 & 0 & 0 & 5.829 & 1.204 & 2.578 & 4.022 & 5.093 & 0 & 0 & 3.435 & 1.102 & 1.731 & 223 & 9.842 & 0 & 0 \\
\hline RS & 2.128 & 745 & 28 & 3.482 & 0 & 0 & 0 & 1.455 & 839 & 1.234 & 2.592 & 125.000 .000 & 0 & 0 & 2.282 & 821 & 3.806 & 4.549 & 0 & 0 & 0 \\
\hline $\mathrm{SC}$ & 0 & 0 & 0 & 4.307 & 0 & 0 & 0 & 3.063 & 1.991 & 4.983 & 9.492 & 0 & 0 & 0 & 1.814 & 1.934 & 10.084 & 5.186 & 0 & 0 & 0 \\
\hline Brasil & 3.139 & 1.639 & 747 & 3.700 & 5.392 & 0 & 2.357 & 2.728 & 1.402 & 271 & 4.267 & 1.418 & 0 & 2.822 & 2.642 & 1.237 & 3.270 & 1.285 & 8.479 & 53.368 & 4.905 \\
\hline
\end{tabular}

Fonte: resultados da pesquisa. 
Tabela 24. Crédito concedido, área e quantidade de contratos por subprogramas, perfis agropecuários e APT "A”, em relação à participação total dos perfis em cada subprograma. Em porcentagem $(\%)$.

\begin{tabular}{|c|c|c|c|c|c|c|c|c|c|c|c|c|c|c|c|}
\hline Subprograma & FAN & FHF & FLT & FLPe & MAN & MLT & MLP & GAN & GHF & GLT & GLP & GSE & Total F & Total M & Total G \\
\hline \multicolumn{16}{|c|}{ Credito Concedido } \\
\hline RPD & 1,5 & 0,0 & 0,6 & 0,0 & 2,4 & 1,0 & 0,6 & 38,3 & 0,3 & 43,3 & 10,6 & 1,4 & 2,1 & 4,1 & 93,8 \\
\hline SPD & 0,1 & 0,0 & 0,3 & 0,0 & 0,1 & 2,8 & 0,0 & 9,6 & 0,0 & 82,9 & 4,0 & 0,2 & 0,4 & 2,9 & 96,8 \\
\hline iLPF & 0,0 & 0,0 & 0,1 & 0,0 & 1,4 & 0,8 & 0,3 & 26,6 & 0,3 & 45,1 & 21,6 & 3,7 & 0,2 & 2,5 & 97,3 \\
\hline FLP & 0,2 & 0,5 & 0,6 & 0,1 & 0,3 & 1,4 & 0,0 & 24,4 & 0,0 & 52,1 & 20,3 & 0,2 & 1,3 & 1,8 & 96,9 \\
\hline ARA & 0,0 & 0,0 & 0,0 & 0,0 & 0,0 & 0,0 & 0,0 & 0,0 & 79,4 & 20,6 & 0,0 & 0,0 & 0,0 & 0,0 & 100,0 \\
\hline TDA & 6,9 & 0,0 & 21,0 & 0,0 & 0,0 & 0,0 & 0,0 & 47,3 & 0,0 & 9,4 & 15,5 & 0,0 & 27,8 & 0,0 & 72,2 \\
\hline OUT & 0,0 & 0,0 & 0,0 & 0,0 & 0,0 & 0,6 & 0,0 & 69,3 & 0,0 & 20,9 & 0,0 & 9,2 & 0,0 & 0,6 & 99,4 \\
\hline \multicolumn{16}{|c|}{ Área } \\
\hline RPD & 1,5 & 0,0 & 0,6 & 0,0 & 3,2 & 0,9 & 0,3 & 40,8 & 0,2 & 42,4 & 9,0 & 1,1 & 2,2 & 4,4 & 93,4 \\
\hline SPD & 0,1 & 0,0 & 0,4 & 0,0 & 0,1 & 3,6 & 0,0 & 6,5 & 0,0 & 86,9 & 1,8 & 0,7 & 0,4 & 3,7 & 95,9 \\
\hline iLPF & 0,0 & 0,0 & 0,1 & 0,0 & 0,2 & 0,2 & 0,0 & 3,7 & 0,0 & 93,6 & 1,7 & 0,5 & 0,1 & 0,4 & 99,5 \\
\hline FLP & 0,0 & 0,4 & 0,5 & 0,0 & 0,4 & 1,5 & 0,0 & 20,4 & 0,0 & 53,5 & 23,0 & 0,1 & 0,9 & 1,9 & 97,1 \\
\hline ARA & 0,0 & 0,0 & 0,0 & 0,0 & 0,0 & 0,0 & 0,0 & 0,0 & 81,3 & 18,7 & 0,0 & 0,0 & 0,0 & 0,0 & 100,0 \\
\hline TDA & 0,0 & 0,0 & 0,0 & 0,0 & 0,0 & 0,0 & 0,0 & 0,0 & 0,0 & 0,0 & 0,0 & 0,0 & 0,0 & 0,0 & 0,0 \\
\hline OUT & 0,0 & 0,0 & 0,0 & 0,0 & 0,0 & 0,0 & 0,0 & 76,7 & 0,0 & 21,9 & 0,0 & 1,3 & 0,0 & 0,0 & 100,0 \\
\hline \multicolumn{16}{|c|}{ Contratos } \\
\hline RPD & 1,6 & 0,0 & 0,7 & 0,0 & 2,5 & 1,4 & 0,8 & 34,5 & 0,4 & 45,9 & 11,3 & 0,9 & 2,4 & 4,6 & 93,0 \\
\hline SPD & 0,4 & 0,0 & 1,4 & 0,0 & 0,1 & 6,8 & 0,0 & 8,6 & 0,0 & 77,7 & 4,7 & 0,2 & 1,7 & 7,0 & 91,3 \\
\hline iLPF & 0,0 & 0,0 & 0,3 & 0,3 & 1,6 & 1,6 & 0,8 & 16,9 & 0,5 & 50,6 & 25,5 & 2,1 & 0,5 & 3,9 & 95,6 \\
\hline FLP & 0,4 & 0,2 & 1,1 & 0,2 & 0,8 & 3,0 & 0,1 & 20,2 & 0,0 & 56,6 & 17,0 & 0,3 & 2,0 & 3,8 & 94,2 \\
\hline ARA & 0,0 & 0,0 & 0,0 & 0,0 & 0,0 & 0,0 & 0,0 & 0,0 & 50,0 & 50,0 & 0,0 & 0,0 & 0,0 & 0,0 & 100,0 \\
\hline TDA & 8,3 & 0,0 & 16,7 & 0,0 & 0,0 & 0,0 & 0,0 & 50,0 & 0,0 & 8,3 & 16,7 & 0,0 & 25,0 & 0,0 & 75,0 \\
\hline OUT & 0,0 & 0,0 & 0,0 & 0,0 & 0,0 & 5,9 & 0,0 & 58,8 & 0,0 & 29,4 & 0,0 & 5,9 & 0,0 & 5,9 & 94,1 \\
\hline
\end{tabular}

Fonte: resultados da pesquisa, dados do IBGE (2017d). 
Tabela 25. Crédito concedido, área e quantidade de contratos por subprogramas, perfis agropecuários e APT "B" em relação à participação total dos perfis em cada subprograma. Em porcentagem $(\%)$.

\begin{tabular}{|c|c|c|c|c|c|c|c|c|c|c|c|c|c|c|c|}
\hline Subprograma & FAN & FLT & FLPe & MAN & MHF & MLT & MLP & GAN & GHF & GLT & GLP & GSE & Total F & Total M & Total G \\
\hline \multicolumn{16}{|c|}{ Crédito Concedido } \\
\hline RPD & 7,4 & 1,0 & 0,1 & 4,0 & 0,0 & 0,6 & 0,4 & 62,0 & 0,3 & 20,3 & 3,5 & 0,4 & 8,5 & 5,0 & 86,4 \\
\hline SPD & 1,9 & 1,5 & 0,0 & 2,1 & 0,0 & 3,1 & 0,0 & 29,5 & 0,1 & 57,0 & 4,8 & 0,0 & 3,4 & 5,2 & 91,4 \\
\hline iLPF & 4,8 & 4,4 & 0,0 & 0,7 & 0,3 & 1,2 & 0,8 & 27,7 & 0,2 & 39,4 & 20,1 & 0,4 & 9,2 & 3,0 & 87,8 \\
\hline FLP & 2,2 & 3,2 & 0,0 & 3,2 & 0,0 & 1,6 & 1,0 & 41,7 & 0,3 & 29,9 & 12,6 & 4,3 & 5,4 & 5,8 & 88,8 \\
\hline ARA & 6,1 & 0,0 & 0,0 & 5,8 & 0,0 & 0,0 & 0,0 & 67,1 & 0,0 & 21,0 & 0,0 & 0,0 & 6,1 & 5,8 & 88,1 \\
\hline TDA & 0,0 & 0,0 & 0,0 & 0,0 & 0,0 & 0,0 & 0,0 & 36,0 & 0,0 & 6,7 & 57,3 & 0,0 & 0,0 & 0,0 & 100,0 \\
\hline OUT & 25,9 & 0,9 & 0,0 & 12,0 & 0,0 & 0,2 & 0,0 & 58,2 & 0,0 & 2,7 & 0,0 & 0,0 & 26,8 & 12,3 & 60,9 \\
\hline \multicolumn{16}{|c|}{ Área } \\
\hline RPD & 5,7 & 0,8 & 0,1 & 4,7 & 0,0 & 0,6 & 0,3 & 64,5 & 0,2 & 20,5 & 2,5 & 0,3 & 6,6 & 5,6 & 87,8 \\
\hline SPD & 1,6 & 3,2 & 0,0 & 2,2 & 0,0 & 3,2 & 0,0 & 23,7 & 0,0 & 64,3 & 1,9 & 0,0 & 4,8 & 5,3 & 89,8 \\
\hline iLPF & 0,2 & 0,3 & 0,0 & 0,0 & 0,0 & 0,1 & 0,0 & 2,0 & 0,0 & 96,5 & 0,7 & 0,0 & 0,6 & 0,2 & 99,2 \\
\hline FLP & 1,7 & 3,7 & 0,0 & 2,8 & 0,0 & 1,1 & 0,7 & 34,8 & 0,2 & 31,8 & 19,7 & 3,4 & 5,5 & 4,6 & 89,9 \\
\hline ARA & 3,0 & 0,0 & 0,0 & 2,5 & 0,0 & 0,0 & 0,0 & 0,8 & 0,0 & 93,8 & 0,0 & 0,0 & 3,0 & 2,5 & 94,6 \\
\hline TDA & 0,0 & 0,0 & 0,0 & 0,0 & 0,0 & 0,0 & 0,0 & 0,0 & 0,0 & 0,0 & 0,0 & 0,0 & 0,0 & 0,0 & 0,0 \\
\hline OUT & 15,5 & 0,4 & 0,0 & 1,3 & 0,0 & 0,4 & 0,0 & 76,8 & 0,0 & 5,6 & 0,0 & 0,0 & 15,9 & 1,7 & 82,4 \\
\hline \multicolumn{16}{|c|}{ Contratos } \\
\hline RPD & 8,5 & 1,3 & 0,2 & 5,1 & 0,0 & 1,0 & 0,6 & 55,2 & 0,3 & 22,4 & 4,7 & 0,7 & 10,1 & 6,7 & 83,3 \\
\hline SPD & 1,4 & 3,5 & 0,0 & 1,8 & 0,0 & 4,3 & 0,0 & 22,5 & 0,1 & 62,0 & 4,5 & 0,0 & 4,9 & 6,1 & 89,0 \\
\hline iLPF & 5,0 & 4,6 & 0,0 & 2,0 & 0,2 & 1,8 & 1,0 & 30,9 & 0,2 & 28,5 & 25,1 & 0,6 & 9,6 & 5,0 & 85,4 \\
\hline FLP & 2,7 & 3,3 & 0,2 & 4,1 & 0,0 & 2,5 & 1,3 & 35,0 & 0,4 & 30,2 & 17,4 & 2,9 & 6,2 & 7,9 & 85,9 \\
\hline ARA & 7,7 & 0,0 & 0,0 & 7,7 & 0,0 & 0,0 & 0,0 & 53,8 & 0,0 & 30,8 & 0,0 & 0,0 & 7,7 & 7,7 & 84,6 \\
\hline TDA & 0,0 & 0,0 & 0,0 & 0,0 & 0,0 & 0,0 & 0,0 & 33,3 & 0,0 & 16,7 & 50,0 & 0,0 & 0,0 & 0,0 & 100,0 \\
\hline OUT & 32,6 & 2,3 & 0,0 & 7,0 & 0,0 & 4,7 & 0,0 & 34,9 & 0,0 & 18,6 & 0,0 & 0,0 & 34,9 & 11,6 & 53,5 \\
\hline
\end{tabular}

Fonte: resultados da pesquisa, dados do IBGE (2017d). 
Tabela 26. Crédito concedido, área e quantidade de contratos por subprogramas, perfis agropecuários e APT "CD" em relação à participação total dos perfis em cada subprograma. Em porcentagem $(\%)$.

\begin{tabular}{|c|c|c|c|c|c|c|c|c|c|c|c|c|c|c|c|c|c|c|c|}
\hline Subprograma & FAG & FAN & FHF & FLT & FLPe & FSE & MAN & MHF & MLT & MLP & MSE & GAN & GHF & GLT & GLP & GSE & Total F & Total M & Total G \\
\hline \multicolumn{20}{|c|}{ Crédito Concedido } \\
\hline RPD & 0,0 & 9,9 & 0,2 & 5,1 & 1,3 & 0,0 & 8,9 & 0,0 & 2,1 & 0,5 & 0,1 & 45,5 & 0,2 & 19,5 & 5,0 & 1,7 & 16,5 & 11,7 & 71,8 \\
\hline SPD & 0,0 & 3,0 & 0,4 & 4,9 & 0,0 & 0,0 & 1,9 & 0,0 & 3,4 & 0,0 & 0,0 & 14,1 & 0,0 & 68,3 & 3,4 & 0,6 & 8,3 & 5,4 & 86,3 \\
\hline iLPF & 0,0 & 5,5 & 0,0 & 8,8 & 1,7 & 0,6 & 5,1 & 0,0 & 0,2 & 0,9 & 0,0 & 35,4 & 0,6 & 26,2 & 8,3 & 6,8 & 16,5 & 6,1 & 77,4 \\
\hline FLP & 2,9 & 7,1 & 0,6 & 7,0 & 0,8 & 0,0 & 5,3 & 0,3 & 3,7 & 0,3 & 0,0 & 48,4 & 0,8 & 15,1 & 4,3 & 3,4 & 18,4 & 9,6 & 72,0 \\
\hline ARA & 0,0 & 0,0 & 0,0 & 55,3 & 0,0 & 0,0 & 0,0 & 0,0 & 0,0 & 0,0 & 0,0 & 10,9 & 0,0 & 16,2 & 0,0 & 17,6 & 55,3 & 0,0 & 44,7 \\
\hline TDA & 0,0 & 9,1 & 0,0 & 1,1 & 1,9 & 0,0 & 0,0 & 0,0 & 1,5 & 0,0 & 0,0 & 35,6 & 0,0 & 6,4 & 44,4 & 0,0 & 12,0 & 1,5 & 86,4 \\
\hline OUT & 0,0 & 1,8 & 0,0 & 0,0 & 0,3 & 0,0 & 4,9 & 0,0 & 3,3 & 0,0 & 0,0 & 18,2 & 0,0 & 19,7 & 51,9 & 0,0 & 2,1 & 8,2 & 89,7 \\
\hline \multicolumn{20}{|c|}{ Área } \\
\hline RPD & 0,0 & 8,5 & 0,1 & 3,9 & 1,1 & 0,0 & 7,6 & 0,0 & 1,4 & 0,6 & 0,0 & 49,6 & 0,1 & 20,8 & 3,4 & 2,8 & 13,7 & 9,6 & 76,7 \\
\hline SPD & 0,0 & 1,9 & 2,6 & 5,5 & 0,0 & 0,0 & 0,7 & 0,0 & 3,3 & 0,0 & 0,0 & 11,8 & 0,0 & 72,5 & 1,2 & 0,4 & 10,1 & 4,0 & 85,9 \\
\hline iLPF & 0,0 & 2,7 & 0,0 & 5,4 & 0,6 & 0,3 & 5,1 & 0,0 & 0,2 & 0,3 & 0,0 & 45,8 & 0,6 & 23,6 & 2,9 & 12,6 & 8,9 & 5,6 & 85,5 \\
\hline FLP & 0,6 & 2,3 & 0,4 & 1,7 & 0,2 & 0,0 & 1,2 & 0,1 & 2,2 & 0,1 & 0,0 & 14,8 & 0,1 & 74,7 & 0,9 & 0,8 & 5,2 & 3,6 & 91,3 \\
\hline ARA & 0,0 & 0,0 & 0,0 & 61,6 & 0,0 & 0,0 & 0,0 & 0,0 & 0,0 & 0,0 & 0,0 & 10,3 & 0,0 & 0,0 & 0,0 & 28,1 & 61,6 & 0,0 & 38,4 \\
\hline TDA & 0,0 & 0,0 & 0,0 & 0,0 & 0,0 & 0,0 & 0,0 & 0,0 & 0,0 & 0,0 & 0,0 & 9,1 & 0,0 & 0,0 & 90,9 & 0,0 & 0,0 & 0,0 & 100,0 \\
\hline OUT & 0,0 & 2,1 & 0,0 & 0,0 & 0,3 & 0,0 & 5,8 & 0,0 & 0,8 & 0,0 & 0,0 & 22,3 & 0,0 & 25,9 & 42,7 & 0,0 & 2,4 & 6,6 & 91,0 \\
\hline \multicolumn{20}{|c|}{ Contratos } \\
\hline RPD & 0,0 & 12,3 & 0,3 & 5,6 & 1,5 & 0,1 & 10,7 & 0,0 & 2,5 & 0,9 & 0,2 & 38,1 & 0,3 & 20,0 & 5,9 & 1,8 & 19,7 & 14,3 & 66,0 \\
\hline SPD & 0,0 & 5,5 & 0,3 & 11,3 & 0,2 & 0,0 & 1,8 & 0,0 & 5,4 & 0,0 & 0,2 & 12,4 & 0,1 & 58,3 & 3,4 & 1,1 & 17,3 & 7,5 & 75,2 \\
\hline iLPF & 0,0 & 8,6 & 0,0 & 12,6 & 4,2 & 1,5 & 4,6 & 0,0 & 0,4 & 2,4 & 0,0 & 21,2 & 1,3 & 20,1 & 14,4 & 8,4 & 27,0 & 7,5 & 65,5 \\
\hline FLP & 0,8 & 11,3 & 0,5 & 11,8 & 3,1 & 0,1 & 6,1 & 0,5 & 4,9 & 1,1 & 0,0 & 20,9 & 1,4 & 20,7 & 11,9 & 4,7 & 27,7 & 12,6 & 59,7 \\
\hline ARA & 0,0 & 0,0 & 0,0 & 25,0 & 0,0 & 0,0 & 0,0 & 0,0 & 0,0 & 0,0 & 0,0 & 25,0 & 0,0 & 25,0 & 0,0 & 25,0 & 25,0 & 0,0 & 75,0 \\
\hline TDA & 0,0 & 18,2 & 0,0 & 3,0 & 6,1 & 0,0 & 0,0 & 0,0 & 3,0 & 0,0 & 0,0 & 36,4 & 0,0 & 12,1 & 21,2 & 0,0 & 27,3 & 3,0 & 69,7 \\
\hline OUT & 0,0 & 7,1 & 0,0 & 0,0 & 3,6 & 0,0 & 7,1 & 0,0 & 7,1 & 0,0 & 0,0 & 35,7 & 0,0 & 32,1 & 7,1 & 0,0 & 10,7 & 14,3 & 75,0 \\
\hline
\end{tabular}

Fonte: resultados da pesquisa, dados do IBGE (2017d). 
ANEXO D. Distribuição dos Recursos do Programa ABC por Atividade e Modalidade

Os quadros presentes neste Anexo utilizam informações contidas na "Base 2". Os dados disponíveis são complementares aos apresentados nos resultados deste trabalho. 
Tabela 27. Crédito concedido agrícola por subprograma, região e APT, em relação ao total da região. Em porcentagem (\%)

\begin{tabular}{|c|c|c|c|c|c|c|c|c|c|c|c|c|c|c|c|c|}
\hline \multirow{2}{*}{ Região } & \multicolumn{5}{|c|}{ Apt. A } & \multicolumn{5}{|c|}{ Apt. B } & \multicolumn{5}{|c|}{ Apt. CD } & \multirow{2}{*}{ TOTAL } \\
\hline & RPD & SPD & iLPF & FLP & OUT* & RPD & SPD & iLPF & FLP & OUT* & RPD & SPD & iLPF & FLP & OUT* & \\
\hline Norte & 0,0 & 0,0 & 0,0 & 0,5 & 0,8 & 6,1 & 17,9 & 1,7 & 5,3 & 1,5 & 2,9 & 36,5 & 5,9 & 15,6 & 5,2 & 100 \\
\hline $\mathrm{AC}$ & 0,0 & 0,0 & 0,0 & 0,0 & 0,0 & 48,7 & 0,0 & 0,0 & 0,0 & 0,0 & 51,3 & 0,0 & 0,0 & 0,0 & 0,0 & 100 \\
\hline $\mathrm{AP}$ & 0,0 & 0,0 & 0,0 & 0,0 & 0,0 & 0,0 & 0,0 & 0,0 & 0,0 & 0,0 & 0,0 & 100,0 & 0,0 & 0,0 & 0,0 & 100 \\
\hline $\mathrm{PA}$ & 0,0 & 0,0 & 0,0 & 0,0 & 0,0 & 34,9 & 16,0 & 2,1 & 0,3 & 1,7 & 2,4 & 13,3 & 5,4 & 7,0 & 16,8 & 100 \\
\hline RO & 0,0 & 0,0 & 0,0 & 0,0 & 0,0 & 20,9 & 21,7 & 0,0 & 14,4 & 9,2 & 0,0 & 0,0 & 0,0 & 32,6 & 1,3 & 100 \\
\hline RR & 0,0 & 0,0 & 0,0 & 0,0 & 0,0 & 0,0 & 0,0 & 0,0 & 0,0 & 0,0 & 0,0 & 67,7 & 32,3 & 0,0 & 0,0 & 100 \\
\hline TO & 0,0 & 0,0 & 0,0 & 0,7 & 1,1 & 0,5 & 19,0 & 2,0 & 5,7 & 0,9 & 3,3 & 40,9 & 5,4 & 16,6 & 4,1 & 100 \\
\hline Nordeste & 0,6 & 43,8 & 2,5 & 2,5 & 0,3 & 0,1 & 3,1 & 1,7 & 2,5 & 0,0 & 0,6 & 38,6 & 1,2 & 2,3 & 0,1 & 100 \\
\hline BA & 0,9 & 61,3 & 3,5 & 3,5 & 0,5 & 0,1 & 2,8 & 2,3 & 3,5 & 0,0 & 0,1 & 18,7 & 1,1 & 1,5 & 0,1 & 100 \\
\hline MA & 0,0 & 0,0 & 0,0 & 0,0 & 0,0 & 0,0 & 0,0 & 0,4 & 0,0 & 0,0 & 1,2 & 89,4 & 1,2 & 7,8 & 0,0 & 100 \\
\hline $\mathrm{PE}$ & 0,0 & 0,0 & 0,0 & 0,0 & 0,0 & 0,0 & 0,0 & 0,0 & 0,0 & 0,0 & 0,0 & 0,0 & 100,0 & 0,0 & 0,0 & 100 \\
\hline PI & 0,0 & 0,0 & 0,0 & 0,0 & 0,0 & 0,0 & 7,1 & 0,0 & 0,0 & 0,0 & 2,2 & 88,8 & 0,6 & 1,4 & 0,0 & 100 \\
\hline Centro-Oeste & 2,3 & 25,8 & 2,7 & 6,1 & 1,5 & 2,0 & 25,1 & 5,3 & 5,4 & 0,6 & 1,5 & 4,6 & 3,7 & 13,4 & 0,2 & 100 \\
\hline $\mathrm{GO}$ & 3,4 & 32,4 & 1,7 & 6,0 & 0,9 & 2,9 & 29,4 & 10,4 & 3,8 & 0,4 & 1,4 & 3,3 & 1,3 & 2,7 & 0,0 & 100 \\
\hline MT & 1,0 & 17,9 & 0,8 & 2,1 & 1,0 & 2,6 & 45,5 & 2,9 & 5,2 & 1,6 & 1,6 & 9,3 & 6,3 & 1,8 & 0,5 & 100 \\
\hline MS & 2,3 & 24,9 & 5,5 & 9,9 & 2,2 & 0,3 & 2,0 & 1,4 & 7,5 & 0,0 & 1,5 & 2,0 & 4,0 & 36,2 & 0,1 & 100 \\
\hline Sudeste & 12,6 & 18,6 & 5,6 & 12,8 & 0,0 & 4,2 & 10,5 & 7,2 & 12,6 & 0,0 & 0,4 & 3,5 & 4,0 & 8,1 & 0,0 & 100 \\
\hline ES & 0,0 & 1,3 & 38,0 & 12,2 & 0,0 & 0,0 & 0,0 & 1,4 & 0,0 & 0,0 & 0,5 & 3,6 & 27,5 & 15,5 & 0,0 & 100 \\
\hline MG & 4,9 & 11,2 & 2,6 & 9,0 & 0,0 & 2,3 & 15,0 & 11,4 & 17,0 & 0,0 & 0,4 & 6,9 & 6,1 & 13,2 & 0,0 & 100 \\
\hline RJ & 0,0 & 0,0 & 10,9 & 13,9 & 0,0 & 0,0 & 0,0 & 0,0 & 0,0 & 0,0 & 3,6 & 0,3 & 8,3 & 63,0 & 0,0 & 100 \\
\hline SP & 20,1 & 26,0 & 6,7 & 16,1 & 0,0 & 6,0 & 7,0 & 3,9 & 9,3 & 0,0 & 0,3 & 0,5 & 1,0 & 3,0 & 0,0 & 100 \\
\hline Sul & 1,5 & 14,7 & 0,4 & 3,0 & 0,0 & 3,6 & 24,4 & 2,5 & 4,8 & 1,1 & 3,5 & 21,8 & 4,0 & 14,5 & 0,1 & 100 \\
\hline PR & 0,5 & 14,6 & 0,2 & 5,7 & 0,0 & 5,1 & 10,4 & 1,1 & 9,9 & 0,8 & 2,2 & 17,6 & 2,5 & 29,3 & 0,3 & 100 \\
\hline $\mathrm{RS}$ & 2,6 & 17,4 & 0,6 & 1,0 & 0,0 & 3,2 & 33,9 & 3,7 & 2,1 & 1,6 & 4,6 & 22,8 & 3,9 & 2,6 & 0,0 & 100 \\
\hline $\mathrm{SC}$ & 0,0 & 0,0 & 0,0 & 3,6 & 0,0 & 0,0 & 25,9 & 1,2 & 0,2 & 0,0 & 2,7 & 33,0 & 10,3 & 23,1 & 0,0 & 100 \\
\hline Brasil & 6,0 & 22,5 & 3,4 & 7,6 & 0,5 & 3,0 & 16,1 & 5,1 & 7,8 & 0,4 & 1,3 & 12,2 & 3,6 & 10,2 & 0,3 & 100 \\
\hline APT & \multicolumn{5}{|c|}{40,0} & \multicolumn{5}{|c|}{32,4} & \multicolumn{5}{|c|}{27,6} & 100 \\
\hline
\end{tabular}

Fonte: resultados da pesquisa. 
Tabela 28. Crédito concedido à pecuária por subprograma, região e APT, em relação ao total da Região. Em porcentagem (\%)

\begin{tabular}{|c|c|c|c|c|c|c|c|c|c|c|c|c|c|c|c|c|}
\hline \multirow{2}{*}{ Região } & \multicolumn{5}{|c|}{ Apt. A } & \multicolumn{5}{|c|}{ Apt. B } & \multicolumn{5}{|c|}{ Apt. CD } & \multirow{2}{*}{ TOTAL } \\
\hline & RPD & SPD & iLPF & FLP & OUT* & RPD & SPD & iLPF & FLP & OUT* & RPD & SPD & iLPF & FLP & OUT* & \\
\hline Norte & 1,0 & 0,0 & 0,0 & 0,1 & 0,1 & 57,8 & 0,4 & 0,4 & 0,1 & 4,1 & 30,3 & 0,4 & 0,5 & 0,1 & 4,8 & 100 \\
\hline $\mathrm{AC}$ & 0,0 & 0,0 & 0,0 & 0,0 & 0,0 & 85,0 & 0,0 & 1,4 & 0,0 & 3,2 & 9,6 & 0,0 & 0,0 & 0,0 & 0,8 & 100 \\
\hline AP & 0,0 & 0,0 & 0,0 & 0,0 & 0,0 & 0,0 & 0,0 & 0,0 & 0,0 & 0,0 & 100,0 & 0,0 & 0,0 & 0,0 & 0,0 & 100 \\
\hline PA & 0,0 & 0,0 & 0,0 & 0,0 & 0,0 & 66,8 & 0,2 & 0,8 & 0,2 & 4,8 & 13,3 & 0,0 & 0,0 & 0,0 & 14,0 & 100 \\
\hline RO & 2,1 & 0,0 & 0,0 & 0,0 & 0,0 & 68,7 & 1,6 & 0,0 & 0,0 & 6,9 & 18,1 & 0,0 & 0,7 & 0,0 & 1,9 & 100 \\
\hline RR & 0,0 & 0,0 & 0,0 & 0,0 & 0,0 & 0,0 & 0,0 & 0,0 & 0,0 & 0,0 & 83,0 & 0,0 & 17,0 & 0,0 & 0,0 & 100 \\
\hline TO & 1,5 & 0,0 & 0,0 & 0,1 & 0,3 & 44,4 & 0,3 & 0,0 & 0,0 & 3,1 & 48,4 & 1,0 & 0,3 & 0,2 & 0,3 & 100 \\
\hline Nordeste & 12,6 & 0,2 & 0,4 & 0,2 & 0,0 & 14,1 & 0,1 & 0,2 & 1,2 & 0,0 & 69,6 & 0,0 & 1,4 & 0,0 & 0,0 & 100 \\
\hline $\mathrm{BA}$ & 22,0 & 0,4 & 0,8 & 0,5 & 0,0 & 22,5 & 0,0 & 0,3 & 2,4 & 0,0 & 50,2 & 0,0 & 0,9 & 0,0 & 0,0 & 100 \\
\hline MA & 3,3 & 0,0 & 0,0 & 0,0 & 0,0 & 5,9 & 0,2 & 0,0 & 0,0 & 0,0 & 88,4 & 0,0 & 2,2 & 0,0 & 0,0 & 100 \\
\hline $\mathrm{PE}$ & 0,0 & 0,0 & 0,0 & 0,0 & 0,0 & 3,9 & 0,0 & 0,0 & 0,0 & 0,0 & 95,3 & 0,0 & 0,0 & 0,8 & 0,0 & 100 \\
\hline PI & 0,0 & 0,0 & 0,0 & 0,0 & 0,0 & 0,0 & 0,0 & 0,0 & 0,0 & 0,0 & 100,0 & 0,0 & 0,0 & 0,0 & 0,0 & 100 \\
\hline Centro-Oeste & 18,7 & 0,9 & 0,3 & 0,4 & 0,1 & 49,4 & 0,3 & 1,1 & 0,6 & 0,1 & 26,9 & 0,5 & 0,5 & 0,3 & 0,0 & 100 \\
\hline $\mathrm{GO}$ & 16,3 & 0,1 & 0,4 & 0,2 & 0,0 & 61,3 & 0,2 & 1,1 & 1,0 & 0,0 & 18,3 & 0,5 & 0,3 & 0,2 & 0,0 & 100 \\
\hline MT & 3,4 & 0,4 & 0,0 & 0,0 & 0,0 & 57,3 & 0,4 & 2,3 & 0,3 & 0,0 & 35,4 & 0,0 & 0,3 & 0,2 & 0,0 & 100 \\
\hline $\mathrm{MS}$ & 38,0 & 2,8 & 0,5 & 1,1 & 0,3 & 22,1 & 0,1 & 0,0 & 0,0 & 0,1 & 32,4 & 0,9 & 1,0 & 0,7 & 0,0 & 100 \\
\hline Sudeste & 26,7 & 0,6 & 0,7 & 0,2 & 0,2 & 34,5 & 0,4 & 0,2 & 0,3 & 0,2 & 34,7 & 0,3 & 0,1 & 0,3 & 0,6 & 100 \\
\hline ES & 31,9 & 0,0 & 0,0 & 0,0 & 0,0 & 9,1 & 0,0 & 0,0 & 0,0 & 0,0 & 58,2 & 0,0 & 0,0 & 0,0 & 0,8 & 100 \\
\hline $\mathrm{MG}$ & 17,6 & 0,3 & 0,7 & 0,2 & 0,3 & 37,0 & 0,4 & 0,1 & 0,2 & 0,2 & 41,3 & 0,4 & 0,2 & 0,4 & 0,7 & 100 \\
\hline RJ & 1,5 & 0,0 & 0,0 & 0,0 & 0,0 & 0,0 & 0,0 & 0,0 & 0,0 & 0,0 & 95,8 & 0,0 & 0,0 & 1,0 & 1,8 & 100 \\
\hline SP & 54,0 & 1,4 & 0,9 & 0,5 & 0,2 & 35,1 & 0,6 & 0,2 & 0,5 & 0,2 & 6,0 & 0,0 & 0,0 & 0,2 & 0,0 & 100 \\
\hline Sul & 27,0 & 0,2 & 2,2 & 0,2 & 0,8 & 15,7 & 0,6 & 1,0 & 0,0 & 0,1 & 44,7 & 0,4 & 4,3 & 0,3 & 2,4 & 100 \\
\hline PR & 29,7 & 0,1 & 2,5 & 0,5 & 1,8 & 16,6 & 0,4 & 0,6 & 0,0 & 0,2 & 40,9 & 0,2 & 4,8 & 0,3 & 1,5 & 100 \\
\hline $\mathrm{RS}$ & 30,5 & 0,3 & 2,3 & 0,0 & 0,0 & 17,7 & 1,0 & 1,8 & 0,0 & 0,0 & 40,8 & 0,7 & 4,2 & 0,3 & 0,3 & 100 \\
\hline $\mathrm{SC}$ & 0,0 & 0,0 & 0,0 & 0,0 & 0,0 & 3,2 & 0,0 & 0,0 & 0,0 & 0,0 & 78,1 & 0,8 & 2,2 & 0,3 & 15,3 & 100 \\
\hline Brasil & 17,9 & 0,6 & 0,5 & 0,3 & 0,2 & 41,7 & 0,3 & 0,7 & 0,4 & 0,8 & 33,9 & 0,4 & 0,8 & 0,3 & 1,2 & 100 \\
\hline APT & \multicolumn{5}{|c|}{19,4} & \multicolumn{5}{|c|}{44,0} & \multicolumn{5}{|c|}{36,6} & 100 \\
\hline
\end{tabular}

Fonte: resultados da pesquisa. 
Tabela 29. Observações agrícolas por subprograma, região e APT, em relação ao total da Região. Em porcentagem (\%)

\begin{tabular}{|c|c|c|c|c|c|c|c|c|c|c|c|c|c|c|c|c|}
\hline \multirow{2}{*}{ Região } & \multicolumn{5}{|c|}{ Apt. A } & \multicolumn{5}{|c|}{ Apt. B } & \multicolumn{5}{|c|}{ Apt. CD } & \multirow{2}{*}{ TOTAL } \\
\hline & RPD & SPD & iLPF & FLP & OUT* & RPD & SPD & iLPF & FLP & OUT* & RPD & SPD & iLPF & FLP & OUT* & \\
\hline Norte & 0,0 & 0,0 & 0,0 & 0,3 & 0,3 & 2,8 & 20,1 & 3,7 & 3,2 & 1,0 & 2,5 & 42,9 & 10,1 & 8,9 & 4,2 & 100 \\
\hline $\mathrm{AC}$ & 0,0 & 0,0 & 0,0 & 0,0 & 0,0 & 50,0 & 0,0 & 0,0 & 0,0 & 0,0 & 50,0 & 0,0 & 0,0 & 0,0 & 0,0 & 100 \\
\hline AP & 0,0 & 0,0 & 0,0 & 0,0 & 0,0 & 0,0 & 0,0 & 0,0 & 0,0 & 0,0 & 0,0 & 100,0 & 0,0 & 0,0 & 0,0 & 100 \\
\hline PA & 0,0 & 0,0 & 0,0 & 0,0 & 0,0 & 17,0 & 27,7 & 8,5 & 2,1 & 2,1 & 6,4 & 10,6 & 10,6 & 4,3 & 10,6 & 100 \\
\hline $\mathrm{RO}$ & 0,0 & 0,0 & 0,0 & 0,0 & 0,0 & 17,6 & 29,4 & 0,0 & 35,3 & 5,9 & 0,0 & 0,0 & 0,0 & 5,9 & 5,9 & 100 \\
\hline $\mathrm{RR}$ & 0,0 & 0,0 & 0,0 & 0,0 & 0,0 & 0,0 & 0,0 & 0,0 & 0,0 & 0,0 & 5,6 & 55,6 & 38,9 & 0,0 & 0,0 & 100 \\
\hline TO & 0,0 & 0,0 & 0,0 & 0,4 & 0,4 & 1,0 & 20,5 & 3,6 & 2,4 & 0,8 & 2,0 & 45,4 & 9,6 & 10,0 & 3,8 & 100 \\
\hline Nordeste & 0,7 & 43,5 & 3,6 & 2,9 & 0,1 & 0,4 & 3,3 & 3,0 & 3,3 & 0,0 & 0,6 & 33,4 & 2,5 & 2,6 & 0,1 & 100 \\
\hline BA & 1,0 & 58,5 & 4,8 & 3,9 & 0,1 & 0,5 & 3,4 & 3,9 & 4,5 & 0,0 & 0,2 & 15,5 & 2,2 & 1,5 & 0,1 & 100 \\
\hline MA & 0,0 & 0,0 & 0,0 & 0,0 & 0,0 & 0,0 & 0,0 & 0,7 & 0,0 & 0,0 & 2,7 & 83,2 & 3,4 & 10,1 & 0,0 & 100 \\
\hline $\mathrm{PE}$ & 0,0 & 0,0 & 0,0 & 0,0 & 0,0 & 0,0 & 0,0 & 0,0 & 0,0 & 0,0 & 0,0 & 0,0 & 100,0 & 0,0 & 0,0 & 100 \\
\hline PI & 0,0 & 0,0 & 0,0 & 0,0 & 0,0 & 0,0 & 6,8 & 0,0 & 0,0 & 0,0 & 0,8 & 90,2 & 0,8 & 1,5 & 0,0 & 100 \\
\hline Centro-Oeste & 2,2 & 30,0 & 3,1 & 4,7 & 0,6 & 1,9 & 31,7 & 7,7 & 4,6 & 0,8 & 1,5 & 5,6 & 2,9 & 2,5 & 0,2 & 100 \\
\hline $\mathrm{GO}$ & 2,5 & 28,2 & 2,5 & 3,7 & 0,3 & 2,2 & 34,4 & 10,5 & 3,6 & 1,2 & 1,0 & 5,2 & 2,3 & 2,2 & 0,0 & 100 \\
\hline MT & 0,3 & 18,7 & 1,0 & 0,7 & 0,3 & 2,2 & 49,0 & 6,1 & 6,2 & 0,7 & 2,0 & 7,9 & 3,0 & 1,5 & 0,3 & 100 \\
\hline MS & 3,7 & 46,5 & 7,1 & 11,6 & 1,4 & 0,8 & 5,5 & 3,3 & 4,9 & 0,0 & 2,0 & 3,9 & 4,3 & 4,5 & 0,4 & 100 \\
\hline Sudeste & 11,4 & 18,7 & 7,3 & 12,5 & 0,0 & 3,7 & 8,6 & 9,3 & 10,7 & 0,0 & 0,5 & 2,1 & 7,4 & 7,8 & 0,0 & 100 \\
\hline ES & 0,0 & 0,8 & 26,6 & 8,9 & 0,0 & 0,0 & 0,0 & 3,2 & 0,0 & 0,0 & 0,4 & 2,4 & 44,0 & 13,7 & 0,0 & 100 \\
\hline MG & 4,0 & 9,7 & 3,7 & 7,2 & 0,0 & 2,2 & 13,9 & 15,6 & 13,4 & 0,1 & 0,6 & 4,1 & 11,7 & 13,8 & 0,0 & 100 \\
\hline $\mathrm{RJ}$ & 0,0 & 0,0 & 10,0 & 20,0 & 0,0 & 0,0 & 0,0 & 0,0 & 0,0 & 0,0 & 10,0 & 5,0 & 15,0 & 40,0 & 0,0 & 100 \\
\hline SP & 17,1 & 26,0 & 8,0 & 16,1 & 0,0 & 4,9 & 6,0 & 5,9 & 9,8 & 0,0 & 0,3 & 0,7 & 1,8 & 3,3 & 0,0 & 100 \\
\hline Sul & 0,9 & 17,8 & 1,0 & 3,1 & 0,0 & 1,4 & 25,2 & 3,5 & 3,3 & 0,3 & 1,5 & 25,1 & 5,9 & 10,9 & 0,1 & 100 \\
\hline PR & 0,7 & 24,0 & 0,7 & 7,6 & 0,0 & 1,1 & 11,5 & 2,2 & 7,0 & 0,3 & 0,9 & 22,5 & 4,8 & 16,5 & 0,2 & 100 \\
\hline $\mathrm{RS}$ & 1,3 & 16,9 & 1,4 & 0,5 & 0,0 & 1,8 & 35,3 & 4,4 & 1,3 & 0,3 & 2,0 & 26,7 & 4,7 & 3,5 & 0,0 & 100 \\
\hline $\mathrm{SC}$ & 0,0 & 0,0 & 0,0 & 1,6 & 0,0 & 0,0 & 19,0 & 3,6 & 0,4 & 0,0 & 0,8 & 25,9 & 16,2 & 32,4 & 0,0 & 100 \\
\hline Brasil & 5,9 & 22,0 & 4,5 & 7,5 & 0,1 & 2,5 & 16,6 & 6,9 & 6,9 & 0,3 & 1,0 & 12,5 & 5,9 & 7,0 & 0,3 & 100 \\
\hline APT & \multicolumn{5}{|c|}{40,1} & \multicolumn{5}{|c|}{33,2} & \multicolumn{5}{|c|}{26,7} & 100 \\
\hline
\end{tabular}

Fonte: resultados da pesquisa. 
Tabela 30. Observações à pecuária por subprograma, região e APT, em relação ao total da Região. Em porcentagem (\%)

\begin{tabular}{|c|c|c|c|c|c|c|c|c|c|c|c|c|c|c|c|c|}
\hline \multirow{2}{*}{ Região } & \multicolumn{5}{|c|}{ Apt. A } & \multicolumn{5}{|c|}{ Apt. B } & \multicolumn{5}{|c|}{ Apt. CD } & \multirow{2}{*}{ TOTAL } \\
\hline & RPD & SPD & iLPF & FLP & OUT* & RPD & SPD & iLPF & FLP & OUT* & RPD & SPD & iLPF & FLP & OUT* & \\
\hline Norte & 1,6 & 0,0 & 0,0 & 0,0 & 0,1 & 56,2 & 0,1 & 0,2 & 0,0 & 1,7 & 38,3 & 0,1 & 0,4 & 0,0 & 1,3 & 100 \\
\hline $\mathrm{AC}$ & 0,0 & 0,0 & 0,0 & 0,0 & 0,0 & 89,7 & 0,0 & 1,1 & 0,0 & 3,4 & 5,6 & 0,0 & 0,0 & 0,0 & 0,2 & 100 \\
\hline AP & 0,0 & 0,0 & 0,0 & 0,0 & 0,0 & 0,0 & 0,0 & 0,0 & 0,0 & 0,0 & 100,0 & 0,0 & 0,0 & 0,0 & 0,0 & 100 \\
\hline PA & 0,0 & 0,0 & 0,0 & 0,0 & 0,0 & 69,6 & 0,2 & 0,1 & 0,1 & 2,1 & 23,8 & 0,0 & 0,0 & 0,0 & 4,0 & 100 \\
\hline RO & 4,7 & 0,0 & 0,0 & 0,0 & 0,0 & 71,3 & 0,3 & 0,0 & 0,0 & 2,2 & 20,0 & 0,0 & 0,3 & 0,0 & 1,2 & 100 \\
\hline RR & 0,0 & 0,0 & 0,0 & 0,0 & 0,0 & 0,0 & 0,0 & 0,0 & 0,0 & 0,0 & 82,6 & 0,0 & 17,4 & 0,0 & 0,0 & 100 \\
\hline TO & 1,7 & 0,0 & 0,0 & 0,0 & 0,3 & 38,2 & 0,0 & 0,0 & 0,0 & 0,9 & 57,7 & 0,3 & 0,2 & 0,0 & 0,5 & 100 \\
\hline Nordeste & 10,7 & 0,1 & 0,2 & 0,1 & 0,0 & 13,5 & 0,1 & 0,1 & 0,3 & 0,0 & 74,3 & 0,0 & 0,8 & 0,2 & 0,0 & 100 \\
\hline $\mathrm{BA}$ & 23,3 & 0,1 & 0,5 & 0,1 & 0,0 & 28,9 & 0,0 & 0,1 & 0,6 & 0,0 & 45,4 & 0,0 & 0,6 & 0,1 & 0,0 & 100 \\
\hline MA & 2,5 & 0,0 & 0,0 & 0,0 & 0,0 & 2,9 & 0,1 & 0,0 & 0,0 & 0,0 & 93,5 & 0,0 & 1,0 & 0,0 & 0,0 & 100 \\
\hline $\mathrm{PE}$ & 0,0 & 0,0 & 0,0 & 0,0 & 0,0 & 4,4 & 0,0 & 0,0 & 0,0 & 0,0 & 92,6 & 0,0 & 0,0 & 2,9 & 0,0 & 100 \\
\hline PI & 0,0 & 0,0 & 0,0 & 0,0 & 0,0 & 0,0 & 0,0 & 0,0 & 0,0 & 0,0 & 100,0 & 0,0 & 0,0 & 0,0 & 0,0 & 100 \\
\hline Centro-Oeste & 22,2 & 0,3 & 0,2 & 0,1 & 0,2 & 48,5 & 0,2 & 0,7 & 0,2 & 0,1 & 26,5 & 0,3 & 0,2 & 0,2 & 0,0 & 100 \\
\hline $\mathrm{GO}$ & 18,6 & 0,1 & 0,1 & 0,1 & 0,0 & 59,2 & 0,2 & 0,9 & 0,3 & 0,1 & 19,7 & 0,2 & 0,3 & 0,1 & 0,0 & 100 \\
\hline MT & 2,6 & 0,1 & 0,0 & 0,0 & 0,0 & 57,8 & 0,3 & 1,3 & 0,3 & 0,1 & 37,2 & 0,1 & 0,2 & 0,1 & 0,0 & 100 \\
\hline $\mathrm{MS}$ & 44,4 & 0,9 & 0,5 & 0,3 & 0,7 & 21,1 & 0,1 & 0,0 & 0,0 & 0,1 & 30,8 & 0,6 & 0,2 & 0,4 & 0,1 & 100 \\
\hline Sudeste & 26,8 & 0,3 & 0,3 & 0,2 & 0,1 & 31,5 & 0,3 & 0,2 & 0,2 & 0,1 & 39,0 & 0,2 & 0,1 & 0,2 & 0,5 & 100 \\
\hline ES & 25,2 & 0,0 & 0,0 & 0,0 & 0,0 & 3,1 & 0,0 & 0,0 & 0,0 & 0,0 & 70,1 & 0,0 & 0,0 & 0,0 & 1,7 & 100 \\
\hline MG & 18,8 & 0,2 & 0,3 & 0,1 & 0,1 & 31,4 & 0,2 & 0,2 & 0,1 & 0,1 & 47,4 & 0,3 & 0,1 & 0,2 & 0,4 & 100 \\
\hline RJ & 2,7 & 0,0 & 0,0 & 0,0 & 0,0 & 0,0 & 0,0 & 0,0 & 0,0 & 0,0 & 94,6 & 0,0 & 0,0 & 0,5 & 2,3 & 100 \\
\hline SP & 48,8 & 0,5 & 0,4 & 0,4 & 0,1 & 39,2 & 0,7 & 0,2 & 0,5 & 0,0 & 8,6 & 0,0 & 0,0 & 0,2 & 0,1 & 100 \\
\hline Sul & 22,0 & 0,3 & 1,5 & 0,1 & 0,3 & 16,8 & 0,3 & 0,5 & 0,0 & 0,0 & 55,2 & 0,3 & 1,9 & 0,2 & 0,7 & 100 \\
\hline PR & 24,8 & 0,1 & 1,6 & 0,1 & 0,6 & 20,9 & 0,6 & 0,6 & 0,0 & 0,1 & 47,1 & 0,3 & 2,3 & 0,1 & 0,6 & 100 \\
\hline $\mathrm{RS}$ & 28,7 & 0,5 & 1,9 & 0,0 & 0,0 & 19,1 & 0,1 & 0,7 & 0,1 & 0,0 & 46,0 & 0,3 & 2,2 & 0,2 & 0,2 & 100 \\
\hline $\mathrm{SC}$ & 0,0 & 0,0 & 0,0 & 0,0 & 0,0 & 1,4 & 0,0 & 0,0 & 0,0 & 0,0 & 95,5 & 0,5 & 0,3 & 0,2 & 2,1 & 100 \\
\hline Brasil & 19,1 & 0,2 & 0,4 & 0,1 & 0,2 & 37,1 & 0,2 & 0,4 & 0,2 & 0,4 & 40,4 & 0,2 & 0,5 & 0,2 & 0,5 & 100 \\
\hline APT & \multicolumn{5}{|c|}{20,0} & \multicolumn{5}{|c|}{38,3} & \multicolumn{5}{|c|}{41,7} & 100 \\
\hline
\end{tabular}

Fonte: resultados da pesquisa. 
Tabela 31. Crédito concedido agrícola por subprogramas, regiões e APT, em relação ao total do Brasil. Em porcentagem (\%).

\begin{tabular}{|c|c|c|c|c|c|c|c|c|c|c|c|c|c|c|c|c|c|c|c|}
\hline \multirow{2}{*}{ Região } & \multicolumn{5}{|c|}{ Apt. A } & \multicolumn{5}{|c|}{ Apt. B } & \multicolumn{5}{|c|}{ Apt. CD } & \multirow[b]{2}{*}{ APT. A } & \multirow{2}{*}{ APT. B } & \multirow{2}{*}{$\begin{array}{c}\text { APT. } \\
\text { CD }\end{array}$} & \multirow{2}{*}{ TOTAL } \\
\hline & RPD & SPD & iLPF & FLP & OUT* & RPD & SPD & iLPF & FLP & OUT* & RPD & SPD & iLPF & FLP & OUT* & & & & \\
\hline Norte & 0,0 & 0,0 & 0,0 & 0,0 & 0,0 & 0,2 & 0,5 & 0,0 & 0,1 & 0,0 & 0,1 & 0,9 & 0,1 & 0,4 & 0,1 & 0,0 & 0,8 & 1,7 & 2,5 \\
\hline $\mathrm{AC}$ & 0,0 & 0,0 & 0,0 & 0,0 & 0,0 & 0,0 & 0,0 & 0,0 & 0,0 & 0,0 & 0,0 & 0,0 & 0,0 & 0,0 & 0,0 & 0,0 & 0,0 & 0,0 & 0,0 \\
\hline AP & 0,0 & 0,0 & 0,0 & 0,0 & 0,0 & 0,0 & 0,0 & 0,0 & 0,0 & 0,0 & 0,0 & 0,0 & 0,0 & 0,0 & 0,0 & 0,0 & 0,0 & 0,0 & 0,0 \\
\hline PA & 0,0 & 0,0 & 0,0 & 0,0 & 0,0 & 0,1 & 0,0 & 0,0 & 0,0 & 0,0 & 0,0 & 0,0 & 0,0 & 0,0 & 0,1 & 0,0 & 0,2 & 0,1 & 0,3 \\
\hline RO & 0,0 & 0,0 & 0,0 & 0,0 & 0,0 & 0,0 & 0,0 & 0,0 & 0,0 & 0,0 & 0,0 & 0,0 & 0,0 & 0,1 & 0,0 & 0,0 & 0,1 & 0,1 & 0,2 \\
\hline RR & 0,0 & 0,0 & 0,0 & 0,0 & 0,0 & 0,0 & 0,0 & 0,0 & 0,0 & 0,0 & 0,0 & 0,1 & 0,0 & 0,0 & 0,0 & 0,0 & 0,0 & 0,1 & 0,1 \\
\hline TO & 0,0 & 0,0 & 0,0 & 0,0 & 0,0 & 0,0 & 0,4 & 0,0 & 0,1 & 0,0 & 0,1 & 0,8 & 0,1 & 0,3 & 0,1 & 0,0 & 0,5 & 1,4 & 1,9 \\
\hline Nordeste & 0,0 & 2,8 & 0,2 & 0,2 & 0,0 & 0,0 & 0,2 & 0,1 & 0,2 & 0,0 & 0,0 & 2,4 & 0,1 & 0,1 & 0,0 & 3,1 & 0,5 & 2,7 & 6,3 \\
\hline $\mathrm{BA}$ & 0,0 & 2,8 & 0,2 & 0,2 & 0,0 & 0,0 & 0,1 & 0,1 & 0,2 & 0,0 & 0,0 & 0,8 & 0,1 & 0,1 & 0,0 & 3,1 & 0,4 & 1,0 & 4,5 \\
\hline MA & 0,0 & 0,0 & 0,0 & 0,0 & 0,0 & 0,0 & 0,0 & 0,0 & 0,0 & 0,0 & 0,0 & 0,7 & 0,0 & 0,1 & 0,0 & 0,0 & 0,0 & 0,8 & 0,8 \\
\hline $\mathrm{PE}$ & 0,0 & 0,0 & 0,0 & 0,0 & 0,0 & 0,0 & 0,0 & 0,0 & 0,0 & 0,0 & 0,0 & 0,0 & 0,0 & 0,0 & 0,0 & 0,0 & 0,0 & 0,0 & 0,0 \\
\hline PI & 0,0 & 0,0 & 0,0 & 0,0 & 0,0 & 0,0 & 0,1 & 0,0 & 0,0 & 0,0 & 0,0 & 0,9 & 0,0 & 0,0 & 0,0 & 0,0 & 0,1 & 0,9 & 1,0 \\
\hline Centro-Oeste & 0,4 & 3,9 & 0,4 & 0,9 & 0,2 & 0,3 & 3,8 & 0,8 & 0,8 & 0,1 & 0,2 & 0,7 & 0,6 & 2,0 & 0,0 & 5,8 & 5,8 & 3,5 & 15,2 \\
\hline $\mathrm{GO}$ & 0,2 & 1,9 & 0,1 & 0,3 & 0,1 & 0,2 & 1,7 & 0,6 & 0,2 & 0,0 & 0,1 & 0,2 & 0,1 & 0,2 & 0,0 & 2,6 & 2,7 & 0,5 & 5,8 \\
\hline MT & 0,0 & 0,8 & 0,0 & 0,1 & 0,0 & 0,1 & 2,0 & 0,1 & 0,2 & 0,1 & 0,1 & 0,4 & 0,3 & 0,1 & 0,0 & 1,0 & 2,6 & 0,9 & 4,5 \\
\hline MS & 0,1 & 1,2 & 0,3 & 0,5 & 0,1 & 0,0 & 0,1 & 0,1 & 0,4 & 0,0 & 0,1 & 0,1 & 0,2 & 1,8 & 0,0 & 2,2 & 0,6 & 2,2 & 5,0 \\
\hline Sudeste & 2,5 & 3,7 & 1,1 & 2,5 & 0,0 & 0,8 & 2,1 & 1,4 & 2,5 & 0,0 & 0,1 & 0,7 & 0,8 & 1,6 & 0,0 & 9,8 & 6,8 & 3,2 & 19,8 \\
\hline ES & 0,0 & 0,0 & 0,2 & 0,1 & 0,0 & 0,0 & 0,0 & 0,0 & 0,0 & 0,0 & 0,0 & 0,0 & 0,1 & 0,1 & 0,0 & 0,2 & 0,0 & 0,2 & 0,5 \\
\hline MG & 0,4 & 1,0 & 0,2 & 0,8 & 0,0 & 0,2 & 1,4 & 1,0 & 1,5 & 0,0 & 0,0 & 0,6 & 0,6 & 1,2 & 0,0 & 2,5 & 4,1 & 2,4 & 9,0 \\
\hline RJ & 0,0 & 0,0 & 0,0 & 0,0 & 0,0 & 0,0 & 0,0 & 0,0 & 0,0 & 0,0 & 0,0 & 0,0 & 0,0 & 0,0 & 0,0 & 0,0 & 0,0 & 0,0 & 0,1 \\
\hline SP & 2,1 & 2,7 & 0,7 & 1,7 & 0,0 & 0,6 & 0,7 & 0,4 & 1,0 & 0,0 & 0,0 & 0,1 & 0,1 & 0,3 & 0,0 & 7,1 & 2,7 & 0,5 & 10,3 \\
\hline Sul & 0,1 & 0,9 & 0,0 & 0,2 & 0,0 & 0,2 & 1,5 & 0,2 & 0,3 & 0,1 & 0,2 & 1,4 & 0,3 & 0,9 & 0,0 & 1,2 & 2,3 & 2,8 & 6,4 \\
\hline PR & 0,0 & 0,3 & 0,0 & 0,1 & 0,0 & 0,1 & 0,2 & 0,0 & 0,2 & 0,0 & 0,1 & 0,4 & 0,1 & 0,7 & 0,0 & 0,5 & 0,6 & 1,2 & 2,4 \\
\hline $\mathrm{RS}$ & 0,1 & 0,6 & 0,0 & 0,0 & 0,0 & 0,1 & 1,1 & 0,1 & 0,1 & 0,1 & 0,2 & 0,8 & 0,1 & 0,1 & 0,0 & 0,7 & 1,5 & 1,1 & 3,4 \\
\hline $\mathrm{SC}$ & 0,0 & 0,0 & 0,0 & 0,0 & 0,0 & 0,0 & 0,2 & 0,0 & 0,0 & 0,0 & 0,0 & 0,2 & 0,1 & 0,1 & 0,0 & 0,0 & 0,2 & 0,4 & 0,6 \\
\hline Brasil & 3,0 & 11,3 & 1,7 & 3,8 & 0,3 & 1,5 & 8,1 & 2,5 & 3,9 & 0,2 & 0,6 & 6,1 & 1,8 & 5,1 & 0,2 & 20,1 & 16,3 & 13,9 & 50,2 \\
\hline
\end{tabular}

Fonte: resultados da pesquisa. 
Tabela 32. Observações agrícolas por subprogramas, regiões e APT, em relação ao total do Brasil. Em porcentagem (\%).

\begin{tabular}{|c|c|c|c|c|c|c|c|c|c|c|c|c|c|c|c|c|c|c|c|}
\hline \multirow{2}{*}{ Região } & \multicolumn{5}{|c|}{ Apt. A } & \multicolumn{5}{|c|}{ Apt. B } & \multicolumn{5}{|c|}{ Apt. CD } & \multirow{2}{*}{ APT. A } & \multirow{2}{*}{ APT. B } & \multirow{2}{*}{$\begin{array}{c}\text { APT. } \\
\text { CD }\end{array}$} & \multirow{2}{*}{ TOTAL } \\
\hline & RPD & SPD & iLPF & FLP & OUT* & RPD & SPD & iLPF & FLP & OUT* & RPD & SPD & iLPF & FLP & OUT* & & & & \\
\hline Norte & 0,0 & 0,0 & 0,0 & 0,0 & 0,0 & 0,0 & 0,3 & 0,1 & 0,1 & 0,0 & 0,0 & 0,7 & 0,2 & 0,1 & 0,1 & 0,0 & 0,5 & 1,1 & 1,7 \\
\hline $\mathrm{AC}$ & 0,0 & 0,0 & 0,0 & 0,0 & 0,0 & 0,0 & 0,0 & 0,0 & 0,0 & 0,0 & 0,0 & 0,0 & 0,0 & 0,0 & 0,0 & 0,0 & 0,0 & 0,0 & 0,0 \\
\hline $\mathrm{AP}$ & 0,0 & 0,0 & 0,0 & 0,0 & 0,0 & 0,0 & 0,0 & 0,0 & 0,0 & 0,0 & 0,0 & 0,0 & 0,0 & 0,0 & 0,0 & 0,0 & 0,0 & 0,0 & 0,0 \\
\hline $\mathrm{PA}$ & 0,0 & 0,0 & 0,0 & 0,0 & 0,0 & 0,0 & 0,0 & 0,0 & 0,0 & 0,0 & 0,0 & 0,0 & 0,0 & 0,0 & 0,0 & 0,0 & 0,1 & 0,1 & 0,1 \\
\hline RO & 0,0 & 0,0 & 0,0 & 0,0 & 0,0 & 0,0 & 0,0 & 0,0 & 0,0 & 0,0 & 0,0 & 0,0 & 0,0 & 0,0 & 0,0 & 0,0 & 0,0 & 0,0 & 0,0 \\
\hline RR & 0,0 & 0,0 & 0,0 & 0,0 & 0,0 & 0,0 & 0,0 & 0,0 & 0,0 & 0,0 & 0,0 & 0,0 & 0,0 & 0,0 & 0,0 & 0,0 & 0,0 & 0,1 & 0,1 \\
\hline TO & 0,0 & 0,0 & 0,0 & 0,0 & 0,0 & 0,0 & 0,3 & 0,1 & 0,0 & 0,0 & 0,0 & 0,6 & 0,1 & 0,1 & 0,1 & 0,0 & 0,4 & 1,0 & 1,4 \\
\hline Nordeste & 0,0 & 1,4 & 0,1 & 0,1 & 0,0 & 0,0 & 0,1 & 0,1 & 0,1 & 0,0 & 0,0 & 1,0 & 0,1 & 0,1 & 0,0 & 1,6 & 0,3 & 1,2 & 3,1 \\
\hline $\mathrm{BA}$ & 0,0 & 1,4 & 0,1 & 0,1 & 0,0 & 0,0 & 0,1 & 0,1 & 0,1 & 0,0 & 0,0 & 0,4 & 0,1 & 0,0 & 0,0 & 1,6 & 0,3 & 0,5 & 2,3 \\
\hline MA & 0,0 & 0,0 & 0,0 & 0,0 & 0,0 & 0,0 & 0,0 & 0,0 & 0,0 & 0,0 & 0,0 & 0,3 & 0,0 & 0,0 & 0,0 & 0,0 & 0,0 & 0,4 & 0,4 \\
\hline $\mathrm{PE}$ & 0,0 & 0,0 & 0,0 & 0,0 & 0,0 & 0,0 & 0,0 & 0,0 & 0,0 & 0,0 & 0,0 & 0,0 & 0,0 & 0,0 & 0,0 & 0,0 & 0,0 & 0,0 & 0,0 \\
\hline PI & 0,0 & 0,0 & 0,0 & 0,0 & 0,0 & 0,0 & 0,0 & 0,0 & 0,0 & 0,0 & 0,0 & 0,3 & 0,0 & 0,0 & 0,0 & 0,0 & 0,0 & 0,3 & 0,4 \\
\hline Centro-Oeste & 0,1 & 1,9 & 0,2 & 0,3 & 0,0 & 0,1 & 2,0 & 0,5 & 0,3 & 0,1 & 0,1 & 0,4 & 0,2 & 0,2 & 0,0 & 2,6 & 3,0 & 0,8 & 6,4 \\
\hline $\mathrm{GO}$ & 0,1 & 0,9 & 0,1 & 0,1 & 0,0 & 0,1 & 1,1 & 0,3 & 0,1 & 0,0 & 0,0 & 0,2 & 0,1 & 0,1 & 0,0 & 1,2 & 1,7 & 0,4 & 3,3 \\
\hline MT & 0,0 & 0,3 & 0,0 & 0,0 & 0,0 & 0,0 & 0,8 & 0,1 & 0,1 & 0,0 & 0,0 & 0,1 & 0,1 & 0,0 & 0,0 & 0,4 & 1,1 & 0,2 & 1,7 \\
\hline MS & 0,1 & 0,7 & 0,1 & 0,2 & 0,0 & 0,0 & 0,1 & 0,0 & 0,1 & 0,0 & 0,0 & 0,1 & 0,1 & 0,1 & 0,0 & 1,0 & 0,2 & 0,2 & 1,4 \\
\hline Sudeste & 1,8 & 2,9 & 1,1 & 1,9 & 0,0 & 0,6 & 1,3 & 1,4 & 1,6 & 0,0 & 0,1 & 0,3 & 1,1 & 1,2 & 0,0 & 7,7 & 5,0 & 2,7 & 15,4 \\
\hline ES & 0,0 & 0,0 & 0,2 & 0,1 & 0,0 & 0,0 & 0,0 & 0,0 & 0,0 & 0,0 & 0,0 & 0,0 & 0,3 & 0,1 & 0,0 & 0,3 & 0,0 & 0,4 & 0,7 \\
\hline MG & 0,2 & 0,6 & 0,2 & 0,4 & 0,0 & 0,1 & 0,8 & 0,9 & 0,8 & 0,0 & 0,0 & 0,2 & 0,7 & 0,8 & 0,0 & 1,4 & 2,6 & 1,7 & 5,7 \\
\hline RJ & 0,0 & 0,0 & 0,0 & 0,0 & 0,0 & 0,0 & 0,0 & 0,0 & 0,0 & 0,0 & 0,0 & 0,0 & 0,0 & 0,0 & 0,0 & 0,0 & 0,0 & 0,0 & 0,1 \\
\hline SP & 1,5 & 2,3 & 0,7 & 1,4 & 0,0 & 0,4 & 0,5 & 0,5 & 0,9 & 0,0 & 0,0 & 0,1 & 0,2 & 0,3 & 0,0 & 6,0 & 2,4 & 0,6 & 9,0 \\
\hline Sul & 0,1 & 1,3 & 0,1 & 0,2 & 0,0 & 0,1 & 1,8 & 0,3 & 0,2 & 0,0 & 0,1 & 1,8 & 0,4 & 0,8 & 0,0 & 1,6 & 2,4 & 3,1 & 7,1 \\
\hline PR & 0,0 & 0,6 & 0,0 & 0,2 & 0,0 & 0,0 & 0,3 & 0,1 & 0,2 & 0,0 & 0,0 & 0,6 & 0,1 & 0,4 & 0,0 & 0,8 & 0,6 & 1,1 & 2,6 \\
\hline $\mathrm{RS}$ & 0,1 & 0,7 & 0,1 & 0,0 & 0,0 & 0,1 & 1,4 & 0,2 & 0,1 & 0,0 & 0,1 & 1,0 & 0,2 & 0,1 & 0,0 & 0,8 & 1,7 & 1,4 & 3,9 \\
\hline $\mathrm{SC}$ & 0,0 & 0,0 & 0,0 & 0,0 & 0,0 & 0,0 & 0,1 & 0,0 & 0,0 & 0,0 & 0,0 & 0,2 & 0,1 & 0,2 & 0,0 & 0,0 & 0,2 & 0,5 & 0,7 \\
\hline Brasil & 2,0 & 7,4 & 1,5 & 2,5 & 0,0 & 0,8 & 5,6 & 2,3 & 2,3 & 0,1 & 0,3 & 4,2 & 2,0 & 2,4 & 0,1 & 13,5 & 11,2 & 9,0 & 33.7 \\
\hline
\end{tabular}

Fonte: resultados da pesquisa. 
Tabela 33. Crédito concedido à pecuária por subprogramas, regiões e APT, em relação ao total do Brasil. Em porcentagem (\%).

\begin{tabular}{|c|c|c|c|c|c|c|c|c|c|c|c|c|c|c|c|c|c|c|c|}
\hline \multirow{2}{*}{ Região } & \multicolumn{5}{|c|}{ Apt. A } & \multicolumn{5}{|c|}{ Apt. B } & \multicolumn{5}{|c|}{ Apt. CD } & \multirow{2}{*}{ APT. A } & \multirow{2}{*}{$\begin{array}{c}\text { APT. } \\
\text { B }\end{array}$} & \multirow{2}{*}{$\begin{array}{c}\text { APT. } \\
\text { CD }\end{array}$} & \multirow{2}{*}{ TOTAL } \\
\hline & RPD & SPD & iLPF & FLP & OUT* & RPD & SPD & iLPF & FLP & OUT* & RPD & SPD & iLPF & FLP & OUT* & & & & \\
\hline Norte & 0,1 & 0,0 & 0,0 & 0,0 & 0,0 & 5,1 & 0,0 & 0,0 & 0,0 & 0,4 & 2,7 & 0,0 & 0,0 & 0,0 & 0,4 & 0,1 & 5,6 & 3,2 & 8,9 \\
\hline $\mathrm{AC}$ & 0,0 & 0,0 & 0,0 & 0,0 & 0,0 & 0,7 & 0,0 & 0,0 & 0,0 & 0,0 & 0,1 & 0,0 & 0,0 & 0,0 & 0,0 & 0,0 & 0,7 & 0,1 & 0,8 \\
\hline AP & 0,0 & 0,0 & 0,0 & 0,0 & 0,0 & 0,0 & 0,0 & 0,0 & 0,0 & 0,0 & 0,0 & 0,0 & 0,0 & 0,0 & 0,0 & 0,0 & 0,0 & 0,0 & 0,0 \\
\hline PA & 0,0 & 0,0 & 0,0 & 0,0 & 0,0 & 1,8 & 0,0 & 0,0 & 0,0 & 0,1 & 0,4 & 0,0 & 0,0 & 0,0 & 0,4 & 0,0 & 2,0 & 0,7 & 2,7 \\
\hline RO & 0,0 & 0,0 & 0,0 & 0,0 & 0,0 & 0,9 & 0,0 & 0,0 & 0,0 & 0,1 & 0,2 & 0,0 & 0,0 & 0,0 & 0,0 & 0,0 & 1,0 & 0,3 & 1,3 \\
\hline RR & 0,0 & 0,0 & 0,0 & 0,0 & 0,0 & 0,0 & 0,0 & 0,0 & 0,0 & 0,0 & 0,1 & 0,0 & 0,0 & 0,0 & 0,0 & 0,0 & 0,0 & 0,1 & 0,1 \\
\hline $\mathrm{TO}$ & 0,1 & 0,0 & 0,0 & 0,0 & 0,0 & 1,7 & 0,0 & 0,0 & 0,0 & 0,1 & 1,9 & 0,0 & 0,0 & 0,0 & 0,0 & 0,1 & 1,9 & 2,0 & 3,9 \\
\hline Nordeste & 0,4 & 0,0 & 0,0 & 0,0 & 0,0 & 0,5 & 0,0 & 0,0 & 0,0 & 0,0 & 2,2 & 0,0 & 0,0 & 0,0 & 0,0 & 0,4 & 0,5 & 2,3 & 3,2 \\
\hline BA & 0,4 & 0,0 & 0,0 & 0,0 & 0,0 & 0,4 & 0,0 & 0,0 & 0,0 & 0,0 & 0,8 & 0,0 & 0,0 & 0,0 & 0,0 & 0,4 & 0,4 & 0,8 & 1,6 \\
\hline MA & 0,0 & 0,0 & 0,0 & 0,0 & 0,0 & 0,1 & 0,0 & 0,0 & 0,0 & 0,0 & 1,3 & 0,0 & 0,0 & 0,0 & 0,0 & 0,0 & 0,1 & 1,3 & 1,4 \\
\hline $\mathrm{PE}$ & 0,0 & 0,0 & 0,0 & 0,0 & 0,0 & 0,0 & 0,0 & 0,0 & 0,0 & 0,0 & 0,1 & 0,0 & 0,0 & 0,0 & 0,0 & 0,0 & 0,0 & 0,1 & 0,1 \\
\hline PI & 0,0 & 0,0 & 0,0 & 0,0 & 0,0 & 0,0 & 0,0 & 0,0 & 0,0 & 0,0 & 0,1 & 0,0 & 0,0 & 0,0 & 0,0 & 0,0 & 0,0 & 0,1 & 0,1 \\
\hline Centro-Oeste & 3,9 & 0,2 & 0,1 & 0,1 & 0,0 & 10,3 & 0,1 & 0,2 & 0,1 & 0,0 & 5,6 & 0,1 & 0,1 & 0,1 & 0,0 & 4,3 & 10,7 & 5,9 & 20,9 \\
\hline $\mathrm{GO}$ & 1,5 & 0,0 & 0,0 & 0,0 & 0,0 & 5,7 & 0,0 & 0,1 & 0,1 & 0,0 & 1,7 & 0,0 & 0,0 & 0,0 & 0,0 & 1,6 & 5,9 & 1,8 & 9,3 \\
\hline MT & 0,2 & 0,0 & 0,0 & 0,0 & 0,0 & 3,3 & 0,0 & 0,1 & 0,0 & 0,0 & 2,1 & 0,0 & 0,0 & 0,0 & 0,0 & 0,2 & 3,5 & 2,1 & 5,8 \\
\hline MS & 2,2 & 0,2 & 0,0 & 0,1 & 0,0 & 1,3 & 0,0 & 0,0 & 0,0 & 0,0 & 1,9 & 0,1 & 0,1 & 0,0 & 0,0 & 2,5 & 1,3 & 2,0 & 5,7 \\
\hline Sudeste & 3,2 & 0,1 & 0,1 & 0,0 & 0,0 & 4,1 & 0,0 & 0,0 & 0,0 & 0,0 & 4,2 & 0,0 & 0,0 & 0,0 & 0,1 & 3,4 & 4,3 & 4,3 & 12,0 \\
\hline ES & 0,2 & 0,0 & 0,0 & 0,0 & 0,0 & 0,1 & 0,0 & 0,0 & 0,0 & 0,0 & 0,3 & 0,0 & 0,0 & 0,0 & 0,0 & 0,2 & 0,1 & 0,3 & 0,6 \\
\hline MG & 1,5 & 0,0 & 0,1 & 0,0 & 0,0 & 3,1 & 0,0 & 0,0 & 0,0 & 0,0 & 3,4 & 0,0 & 0,0 & 0,0 & 0,1 & 1,6 & 3,2 & 3,6 & 8,3 \\
\hline RJ & 0,0 & 0,0 & 0,0 & 0,0 & 0,0 & 0,0 & 0,0 & 0,0 & 0,0 & 0,0 & 0,2 & 0,0 & 0,0 & 0,0 & 0,0 & 0,0 & 0,0 & 0,2 & 0,2 \\
\hline SP & 1,6 & 0,0 & 0,0 & 0,0 & 0,0 & 1,0 & 0,0 & 0,0 & 0,0 & 0,0 & 0,2 & 0,0 & 0,0 & 0,0 & 0,0 & 1,6 & 1,1 & 0,2 & 2,9 \\
\hline Sul & 1,3 & 0,0 & 0,1 & 0,0 & 0,0 & 0,8 & 0,0 & 0,1 & 0,0 & 0,0 & 2,2 & 0,0 & 0,2 & 0,0 & 0,1 & 1,5 & 0,8 & 2,5 & 4,9 \\
\hline PR & 0,7 & 0,0 & 0,1 & 0,0 & 0,0 & 0,4 & 0,0 & 0,0 & 0,0 & 0,0 & 0,9 & 0,0 & 0,1 & 0,0 & 0,0 & 0,8 & 0,4 & 1,1 & 2,3 \\
\hline $\mathrm{RS}$ & 0,6 & 0,0 & 0,0 & 0,0 & 0,0 & 0,4 & 0,0 & 0,0 & 0,0 & 0,0 & 0,9 & 0,0 & 0,1 & 0,0 & 0,0 & 0,7 & 0,4 & 1,0 & 2,1 \\
\hline $\mathrm{SC}$ & 0,0 & 0,0 & 0,0 & 0,0 & 0,0 & 0,0 & 0,0 & 0,0 & 0,0 & 0,0 & 0,4 & 0,0 & 0,0 & 0,0 & 0,1 & 0,0 & 0,0 & 0,5 & 0,5 \\
\hline Brasi & 8,9 & 0,3 & 03 & 0.1 & 0,1 & 20,8 & 0,2 & 0,3 & 0,2 & 0,4 & 16,8 & 0,2 & 0,4 & 0.1 & 0,6 & 9,7 & 219 & 18,2 & \\
\hline
\end{tabular}

Fonte: resultados da pesquisa. 
Tabela 34. Observações da Pecuária por subprogramas, regiões e APT, em relação ao total do Brasil. Em porcentagem (\%).

\begin{tabular}{|c|c|c|c|c|c|c|c|c|c|c|c|c|c|c|c|c|c|c|c|}
\hline \multirow{2}{*}{ Região } & \multicolumn{5}{|c|}{ Apt. A } & \multicolumn{5}{|c|}{ Apt. B } & \multicolumn{5}{|c|}{ Apt. CD } & \multirow{2}{*}{ APT. A } & \multirow{2}{*}{$\begin{array}{c}\text { APT. } \\
\text { B }\end{array}$} & \multirow{2}{*}{$\begin{array}{c}\text { APT. } \\
\text { CD }\end{array}$} & \multirow{2}{*}{ TOTAL } \\
\hline & RPD & SPD & iLPF & FLP & OUT* & RPD & SPD & iLPF & FLP & OUT* & RPD & SPD & iLPF & FLP & OUT* & & & & \\
\hline Norte & 0,2 & 0,0 & 0,0 & 0,0 & 0,0 & 6,4 & 0,0 & 0,0 & 0,0 & 0,2 & 4,4 & 0,0 & 0,0 & 0,0 & 0,1 & 0,2 & 6,6 & 4,6 & 11,4 \\
\hline $\mathrm{AC}$ & 0,0 & 0,0 & 0,0 & 0,0 & 0,0 & 1,4 & 0,0 & 0,0 & 0,0 & 0,1 & 0,1 & 0,0 & 0,0 & 0,0 & 0,0 & 0,0 & 1,5 & 0,1 & 1,5 \\
\hline $\mathrm{AP}$ & 0,0 & 0,0 & 0,0 & 0,0 & 0,0 & 0,0 & 0,0 & 0,0 & 0,0 & 0,0 & 0,0 & 0,0 & 0,0 & 0,0 & 0,0 & 0,0 & 0,0 & 0,0 & 0,0 \\
\hline PA & 0,0 & 0,0 & 0,0 & 0,0 & 0,0 & 1,6 & 0,0 & 0,0 & 0,0 & 0,0 & 0,5 & 0,0 & 0,0 & 0,0 & 0,1 & 0,0 & 1,6 & 0,6 & 2,2 \\
\hline $\mathrm{RO}$ & 0,1 & 0,0 & 0,0 & 0,0 & 0,0 & 1,3 & 0,0 & 0,0 & 0,0 & 0,0 & 0,4 & 0,0 & 0,0 & 0,0 & 0,0 & 0,1 & 1,3 & 0,4 & 1,8 \\
\hline RR & 0,0 & 0,0 & 0,0 & 0,0 & 0,0 & 0,0 & 0,0 & 0,0 & 0,0 & 0,0 & 0,1 & 0,0 & 0,0 & 0,0 & 0,0 & 0,0 & 0,0 & 0,1 & 0,1 \\
\hline $\mathrm{TO}$ & 0,1 & 0,0 & 0,0 & 0,0 & 0,0 & 2,2 & 0,0 & 0,0 & 0,0 & 0,1 & 3,3 & 0,0 & 0,0 & 0,0 & 0,0 & 0,1 & 2,2 & 3,3 & 5,6 \\
\hline Nordeste & 0,6 & 0,0 & 0,0 & 0,0 & 0,0 & 0,7 & 0,0 & 0,0 & 0,0 & 0,0 & 4,0 & 0,0 & 0,0 & 0,0 & 0,0 & 0,6 & 0,7 & 4,1 & 5,4 \\
\hline $\mathrm{BA}$ & 0,5 & 0,0 & 0,0 & 0,0 & 0,0 & 0,6 & 0,0 & 0,0 & 0,0 & 0,0 & 1,0 & 0,0 & 0,0 & 0,0 & 0,0 & 0,5 & 0,6 & 1,0 & 2,2 \\
\hline MA & 0,1 & 0,0 & 0,0 & 0,0 & 0,0 & 0,1 & 0,0 & 0,0 & 0,0 & 0,0 & 2,7 & 0,0 & 0,0 & 0,0 & 0,0 & 0,1 & 0,1 & 2,7 & 2,9 \\
\hline $\mathrm{PE}$ & 0,0 & 0,0 & 0,0 & 0,0 & 0,0 & 0,0 & 0,0 & 0,0 & 0,0 & 0,0 & 0,2 & 0,0 & 0,0 & 0,0 & 0,0 & 0,0 & 0,0 & 0,2 & 0,2 \\
\hline PI & 0,0 & 0,0 & 0,0 & 0,0 & 0,0 & 0,0 & 0,0 & 0,0 & 0,0 & 0,0 & 0,1 & 0,0 & 0,0 & 0,0 & 0,0 & 0,0 & 0,0 & 0,1 & 0,1 \\
\hline Centro-Oeste & 4,3 & 0,1 & 0,0 & 0,0 & 0,0 & 9,3 & 0,0 & 0,1 & 0,0 & 0,0 & 5,1 & 0,1 & 0,0 & 0,0 & 0,0 & 4,4 & 9,6 & 5,2 & 19,3 \\
\hline $\mathrm{GO}$ & 1,8 & 0,0 & 0,0 & 0,0 & 0,0 & 5,8 & 0,0 & 0,1 & 0,0 & 0,0 & 1,9 & 0,0 & 0,0 & 0,0 & 0,0 & 1,9 & 6,0 & 2,0 & 9,8 \\
\hline MT & 0,1 & 0,0 & 0,0 & 0,0 & 0,0 & 2,4 & 0,0 & 0,1 & 0,0 & 0,0 & 1,6 & 0,0 & 0,0 & 0,0 & 0,0 & 0,1 & 2,5 & 1,6 & 4,2 \\
\hline MS & 2,3 & 0,0 & 0,0 & 0,0 & 0,0 & 1,1 & 0,0 & 0,0 & 0,0 & 0,0 & 1,6 & 0,0 & 0,0 & 0,0 & 0,0 & 2,5 & 1,1 & 1,7 & 5,2 \\
\hline Sudeste & 5,6 & 0,1 & 0,1 & 0,0 & 0,0 & 6,6 & 0,1 & 0,0 & 0,1 & 0,0 & 8,2 & 0,0 & 0,0 & 0,0 & 0,1 & 5,8 & 6,8 & 8,4 & 20,9 \\
\hline ES & 0,2 & 0,0 & 0,0 & 0,0 & 0,0 & 0,0 & 0,0 & 0,0 & 0,0 & 0,0 & 0,6 & 0,0 & 0,0 & 0,0 & 0,0 & 0,2 & 0,0 & 0,6 & 0,8 \\
\hline MG & 2,6 & 0,0 & 0,0 & 0,0 & 0,0 & 4,3 & 0,0 & 0,0 & 0,0 & 0,0 & 6,5 & 0,0 & 0,0 & 0,0 & 0,1 & 2,7 & 4,4 & 6,6 & 13,7 \\
\hline $\mathrm{RJ}$ & 0,0 & 0,0 & 0,0 & 0,0 & 0,0 & 0,0 & 0,0 & 0,0 & 0,0 & 0,0 & 0,6 & 0,0 & 0,0 & 0,0 & 0,0 & 0,0 & 0,0 & 0,6 & 0,6 \\
\hline SP & 2,8 & 0,0 & 0,0 & 0,0 & 0,0 & 2,2 & 0,0 & 0,0 & 0,0 & 0,0 & 0,5 & 0,0 & 0,0 & 0,0 & 0,0 & 2,9 & 2,3 & 0,5 & 5,7 \\
\hline Sul & 2,0 & 0,0 & 0,1 & 0,0 & 0,0 & 1,6 & 0,0 & 0,1 & 0,0 & 0,0 & 5,1 & 0,0 & 0,2 & 0,0 & 0,1 & 2,2 & 1,6 & 5,4 & 9,3 \\
\hline PR & 1,0 & 0,0 & 0,1 & 0,0 & 0,0 & 0,8 & 0,0 & 0,0 & 0,0 & 0,0 & 1,9 & 0,0 & 0,1 & 0,0 & 0,0 & 1,1 & 0,9 & 2,0 & 3,9 \\
\hline $\mathrm{RS}$ & 1,1 & 0,0 & 0,1 & 0,0 & 0,0 & 0,7 & 0,0 & 0,0 & 0,0 & 0,0 & 1,7 & 0,0 & 0,1 & 0,0 & 0,0 & 1,2 & 0,7 & 1,8 & 3,7 \\
\hline $\mathrm{SC}$ & 0,0 & 0,0 & 0,0 & 0,0 & 0,0 & 0,0 & 0,0 & 0,0 & 0,0 & 0,0 & 1,6 & 0,0 & 0,0 & 0,0 & 0,0 & 0,0 & 0,0 & 1,6 & 1,6 \\
\hline Brasil & 12,7 & 0,1 & 0,3 & 0,1 & 0,1 & 24,6 & 0,1 & 0,2 & 0,1 & 0,2 & 26,8 & 0,1 & 0,3 & 0,1 & 0,3 & 13,3 & 25,4 & 27,6 & 66,3 \\
\hline
\end{tabular}

Fonte: resultados da pesquisa. 
Tabela 35. Crédito concedido e observações em RPD, por regiões e modalidades, em relação ao total das regiões e do Brasil. Em porcentagem (\%).

\begin{tabular}{|c|c|c|c|c|c|c|c|c|c|c|c|c|c|c|c|c|c|c|c|c|c|c|c|c|}
\hline \multirow{2}{*}{ Região } & \multicolumn{6}{|c|}{ CRÉDITO CONCEDIDO } & \multicolumn{6}{|c|}{ OBSERVAÇÕES } & \multicolumn{6}{|c|}{ CRÉDITO CONCEDIDO } & \multicolumn{6}{|c|}{ OBSERVAÇÕES } \\
\hline & $\mathbf{A A}$ & FCP & MEQ & MEX & OM & TOTAL & $\mathbf{A A}$ & FCP & MEQ & MEX & OM & TOTAL & $\mathbf{A A}$ & FCP & MEQ & MEX & OM & TOTAL & $\mathbf{A A}$ & FCP & MEQ & MEX & OM & TOTAL \\
\hline Norte & 21,4 & 0,6 & 1,6 & 68,1 & 7,8 & 100 & 26,5 & 0,3 & 8,4 & 58,3 & 5,5 & 100 & 3,4 & 0,1 & 0,3 & 10,8 & 1,2 & 15,9 & 4,4 & 0,0 & 1,4 & 9,6 & 0,9 & 16,5 \\
\hline $\mathrm{AC}$ & 25,8 & 0,8 & 3,8 & 60,1 & 9,6 & 100 & 22,9 & 0,4 & 19,0 & 52,1 & 5,6 & 100 & 0,4 & 0,0 & 0,1 & 0,9 & 0,1 & 1,5 & 0,5 & 0,0 & 0,4 & 1,2 & 0,1 & 2,2 \\
\hline $\mathrm{AP}$ & 0,0 & 0,0 & 0,0 & 100,0 & 0,0 & 100 & 0,0 & 0,0 & 0,0 & 100,0 & 0,0 & 100 & 0,0 & 0,0 & 0,0 & 0,0 & 0,0 & 0,0 & 0,0 & 0,0 & 0,0 & 0,0 & 0,0 & 0,0 \\
\hline $\mathrm{PA}$ & 21,8 & 0,0 & 1,3 & 71,4 & 5,5 & 100 & 26,1 & 0,0 & 10,8 & 59,7 & 3,5 & 100 & 1,0 & 0,0 & 0,1 & 3,2 & 0,2 & 4,5 & 0,8 & 0,0 & 0,3 & 1,9 & 0,1 & 3,2 \\
\hline $\mathrm{RO}$ & 22,1 & 0,1 & 2,7 & 70,0 & 5,1 & 100 & 25,0 & 0,2 & 13,3 & 58,8 & 2,5 & 100 & 0,5 & 0,0 & 0,1 & 1,7 & 0,1 & 2,4 & 0,7 & 0,0 & 0,4 & 1,6 & 0,1 & 2,7 \\
\hline RR & 26,6 & 0,0 & 0,9 & 52,8 & 19,8 & 100 & 28,6 & 0,0 & 2,4 & 59,5 & 9,5 & 100 & 0,1 & 0,0 & 0,0 & 0,1 & 0,0 & 0,2 & 0,0 & 0,0 & 0,0 & 0,1 & 0,0 & 0,2 \\
\hline TO & 19,9 & 1,1 & 1,0 & 67,3 & 9,4 & 100 & 28,1 & 0,5 & 3,3 & 59,1 & 7,3 & 100 & 1,4 & 0,1 & 0,1 & 4,9 & 0,7 & 7,3 & 2,3 & 0,0 & 0,3 & 4,8 & 0,6 & 8,2 \\
\hline Nordeste & 24,0 & 0,4 & 1,0 & 61,8 & 12,2 & 100 & 26,7 & 0,4 & 4,8 & 59,6 & 7,9 & 100 & 1,5 & 0,0 & 0,1 & 3,9 & 0,8 & 6,3 & 2,2 & 0,0 & 0,4 & 4,9 & 0,7 & 8,2 \\
\hline $\mathrm{BA}$ & 21,8 & 0,8 & 0,6 & 61,3 & 15,4 & 100 & 24,8 & 0,9 & 3,2 & 59,9 & 11,0 & 100 & 0,7 & 0,0 & 0,0 & 1,9 & 0,5 & 3,2 & 0,8 & 0,0 & 0,1 & 2,0 & 0,4 & 3,3 \\
\hline MA & 27,5 & 0,0 & 1,0 & 61,1 & 9,5 & 100 & 27,8 & 0,0 & 5,7 & 59,9 & 5,5 & 100 & 0,8 & 0,0 & 0,0 & 1,7 & 0,3 & 2,7 & 1,2 & 0,0 & 0,2 & 2,5 & 0,2 & 4,3 \\
\hline $\mathrm{PE}$ & 20,1 & 0,0 & 6,7 & 69,7 & 3,6 & 100 & 24,1 & 0,0 & 6,0 & 62,7 & 7,2 & 100 & 0,0 & 0,0 & 0,0 & 0,1 & 0,0 & 0,2 & 0,1 & 0,0 & 0,0 & 0,2 & 0,0 & 0,3 \\
\hline PI & 18,4 & 0,0 & 0,2 & 78,6 & 2,7 & 100 & 40,0 & 0,0 & 4,0 & 52,0 & 4,0 & 100 & 0,0 & 0,0 & 0,0 & 0,1 & 0,0 & 0,2 & 0,1 & 0,0 & 0,0 & 0,1 & 0,0 & 0,2 \\
\hline Centro-Oeste & 15,0 & 1,8 & 0,6 & 69,2 & 12,9 & 100 & 21,0 & 0,9 & 2,7 & 64,9 & 9,8 & 100 & 6,0 & 0,7 & 0,2 & 27,5 & 5,1 & 39,7 & 5,9 & 0,3 & 0,8 & 18,3 & 2,8 & 28,1 \\
\hline GO & 11,6 & 2,6 & 0,5 & 75,2 & 9,6 & 100 & 16,4 & 1,0 & 2,6 & 70,3 & 8,7 & 100 & 2,1 & 0,5 & 0,1 & 13,5 & 1,7 & 17,9 & 2,4 & 0,1 & 0,4 & 10,1 & 1,3 & 14,4 \\
\hline MT & 18,2 & 1,0 & 1,0 & 62,4 & 17,3 & 100 & 27,3 & 0,7 & 3,8 & 58,0 & 10,0 & 100 & 2,0 & 0,1 & 0,1 & 7,0 & 1,9 & 11,2 & 1,7 & 0,0 & 0,2 & 3,6 & 0,6 & 6,2 \\
\hline MS & 17,5 & 1,4 & 0,4 & 66,2 & 14,0 & 100 & 24,6 & 0,8 & 1,9 & 60,3 & 11,7 & 100 & 1,8 & 0,2 & 0,0 & 7,0 & 1,5 & 10,6 & 1,9 & 0,1 & 0,1 & 4,6 & 0,9 & 7,6 \\
\hline Sudeste & 17,1 & 21,2 & 0,5 & 48,0 & 12,6 & 100 & 23,4 & 9,7 & 3,0 & 53,0 & 10,0 & 100 & 4,9 & 6,1 & 0,2 & 13,8 & 3,6 & 28,7 & 7,9 & 3,3 & 1,0 & 17,9 & 3,4 & 33,8 \\
\hline ES & 14,3 & 0,0 & 1,1 & 75,5 & 8,7 & 100 & 20,2 & 0,0 & 3,7 & 68,0 & 7,7 & 100 & 0,2 & 0,0 & 0,0 & 0,8 & 0,1 & 1,1 & 0,2 & 0,0 & 0,0 & 0,8 & 0,1 & 1,2 \\
\hline MG & 20,2 & 7,3 & 0,6 & 55,4 & 15,7 & 100 & 25,6 & 2,3 & 3,3 & 57,5 & 10,3 & 100 & 3,4 & 1,2 & 0,1 & 9,2 & 2,6 & 16,7 & 5,2 & 0,5 & 0,7 & 11,8 & 2,1 & 20,4 \\
\hline $\mathrm{RJ}$ & 27,4 & 0,5 & 4,0 & 61,8 & 5,7 & 100 & 24,5 & 0,4 & 10,0 & 60,7 & 3,9 & 100 & 0,1 & 0,0 & 0,0 & 0,3 & 0,0 & 0,4 & 0,2 & 0,0 & 0,1 & 0,6 & 0,0 & 0,9 \\
\hline SP & 12,0 & 46,1 & 0,3 & 32,9 & 8,3 & 100 & 19,7 & 25,0 & 2,0 & 42,3 & 10,4 & 100 & 1,3 & 4,9 & 0,0 & 3,5 & 0,9 & 10,5 & 2,2 & 2,8 & 0,2 & 4,7 & 1,2 & 11,2 \\
\hline Sul & 21,3 & 0,3 & 1,9 & 65,6 & 9,7 & 100 & 23,2 & 0,3 & 6,1 & 59,4 & 9,5 & 100 & 2,0 & 0,0 & 0,2 & 6,2 & 0,9 & 9,4 & 3,1 & 0,0 & 0,8 & 7,9 & 1,3 & 13,3 \\
\hline PR & 19,1 & 0,5 & 1,7 & 67,5 & 9,3 & 100 & 24,0 & 0,4 & 5,6 & 57,6 & 10,4 & 100 & 0,8 & 0,0 & 0,1 & 2,9 & 0,4 & 4,3 & 1,3 & 0,0 & 0,3 & 3,2 & 0,6 & 5,6 \\
\hline RS & 24,2 & 0,1 & 1,7 & 62,6 & 10,5 & 100 & 24,0 & 0,3 & 4,9 & 59,4 & 10,3 & 100 & 1,0 & 0,0 & 0,1 & 2,7 & 0,5 & 4,3 & 1,3 & 0,0 & 0,3 & 3,2 & 0,6 & 5,4 \\
\hline SC & 17,4 & 0,0 & 3,1 & 71,0 & 7,2 & 100 & 19,5 & 0,0 & 10,2 & 63,5 & 5,6 & 100 & 0,1 & 0,0 & 0,0 & 0,6 & 0,1 & 0,8 & 0,5 & 0,0 & 0,2 & 1,5 & 0,1 & 2,4 \\
\hline Brasil & 17,8 & 7,0 & 0,9 & 62,1 & 11,7 & 100 & 23,5 & 3,7 & 4,4 & 58,6 & 9,0 & 100 & 17,8 & 7,0 & 0,9 & 62,1 & 11,7 & 100 & 23,5 & 3,7 & 4,4 & 58,6 & 9,0 & 100 \\
\hline
\end{tabular}

Fonte: resultados da pesquisa. 
Tabela 36. Crédito concedido e observações em SPD, por regiões e modalidades, em relação ao total das regiões e do Brasil. Em porcentagem (\%).

\begin{tabular}{|c|c|c|c|c|c|c|c|c|c|c|c|c|c|c|c|c|c|c|c|c|}
\hline \multirow{2}{*}{ Região } & \multicolumn{5}{|c|}{ CRÉDITO CONCEDIDO } & \multicolumn{5}{|c|}{ OBSERVAÇÕES } & \multicolumn{5}{|c|}{ CRÉDITO CONCEDIDO } & \multicolumn{5}{|c|}{ OBSERVAÇÕES } \\
\hline & FCP & MEQ & MEX & OM & \begin{tabular}{|l|} 
TOTAL \\
\end{tabular} & FCP & MEQ & MEX & OM & \begin{tabular}{|l|} 
TOTAL \\
\end{tabular} & FCP & MEQ & MEX & OM & \begin{tabular}{|l|} 
TOTAL \\
\end{tabular} & FCP & MEQ & MEX & $\mathbf{O M}$ & TOTAL \\
\hline Norte & 0,2 & 1,8 & 89,4 & 8,6 & 100 & 0,3 & 3,4 & 87,1 & 9,3 & 100 & 0,0 & 0,1 & 4,9 & 0,5 & 5,5 & 0,0 & 0,2 & 5,3 & 0,6 & 6,1 \\
\hline $\mathrm{AC}$ & 0,0 & 0,0 & 0,0 & 0,0 & 0 & 0,0 & 0,0 & 0,0 & 0,0 & 0 & 0,0 & 0,0 & 0,0 & 0,0 & 0,0 & 0,0 & 0,0 & 0,0 & 0,0 & 0,0 \\
\hline $\mathrm{AP}$ & 0,0 & 0,0 & 100,0 & 0,0 & 100 & 0,0 & 0,0 & 100,0 & 0,0 & 100 & 0,0 & 0,0 & 0,1 & 0,0 & 0,1 & 0,0 & 0,0 & 0,2 & 0,0 & 0,2 \\
\hline PA & 0,0 & 2,9 & 80,6 & 16,5 & 100 & 0,0 & 5,0 & 70,0 & 25,0 & 100 & 0,0 & 0,0 & 0,3 & 0,1 & 0,4 & 0,0 & 0,0 & 0,2 & 0,1 & 0,3 \\
\hline RO & 0,0 & 4,3 & 51,9 & 43,8 & 100 & 0,0 & 25,0 & 37,5 & 37,5 & 100 & 0,0 & 0,0 & 0,1 & 0,1 & 0,2 & 0,0 & 0,0 & 0,0 & 0,0 & 0,1 \\
\hline RR & 0,0 & 0,0 & 100,0 & 0,0 & 100 & 0,0 & 0,0 & 100,0 & 0,0 & 100 & 0,0 & 0,0 & 0,2 & 0,0 & 0,2 & 0,0 & 0,0 & 0,2 & 0,0 & 0,2 \\
\hline TO & 0,2 & 1,7 & 91,1 & 6,9 & 100 & 0,3 & 3,0 & 88,4 & 8,4 & 100 & 0,0 & 0,1 & 4,2 & 0,3 & 4,6 & 0,0 & 0,2 & 4,7 & 0,4 & 5,3 \\
\hline Nordeste & 0,1 & 0,1 & 96,6 & 3,1 & 100 & 0,2 & 0,8 & 92,1 & 6,9 & 100 & 0,0 & 0,0 & 20,0 & 0,6 & 20,7 & 0,0 & 0,1 & 13,1 & 1,0 & 14,2 \\
\hline BA & 0,0 & 0,1 & 96,4 & 3,5 & 100 & 0,2 & 0,9 & 91,1 & 7,8 & 100 & 0,0 & 0,0 & 13,7 & 0,5 & 14,2 & 0,0 & 0,1 & 9,2 & 0,8 & 10,1 \\
\hline MA & 0,0 & 0,0 & 97,7 & 2,3 & 100 & 0,0 & 0,0 & 96,1 & 3,9 & 100 & 0,0 & 0,0 & 2,7 & 0,1 & 2,8 & 0,0 & 0,0 & 1,9 & 0,1 & 2,0 \\
\hline $\mathrm{PE}$ & 0,0 & 0,0 & 0,0 & 0,0 & 0 & 0,0 & 0,0 & 0,0 & 0,0 & 0 & 0,0 & 0,0 & 0,0 & 0,0 & 0,0 & 0,0 & 0,0 & 0,0 & 0,0 & 0,0 \\
\hline PI & 0,0 & 0,3 & 97,5 & 2,2 & 100 & 0,0 & 0,8 & 93,8 & 5,4 & 100 & 0,0 & 0,0 & 3,5 & 0,1 & 3,6 & 0,0 & 0,0 & 1,9 & 0,1 & 2,0 \\
\hline Centro-Oeste & 7,7 & 0,4 & 83,6 & 8,1 & 100 & 5,8 & 1,1 & 83,8 & 8,9 & 100 & 2,6 & 0,1 & 28,1 & 2,7 & 33,6 & 1,5 & 0,3 & 21,2 & 2,3 & 25,3 \\
\hline $\mathrm{GO}$ & 16,4 & 0,4 & 78,7 & 4,4 & 100 & 10,2 & 1,1 & 81,6 & 7,0 & 100 & 2,4 & 0,1 & 11,5 & 0,6 & 14,6 & 1,3 & 0,1 & 10,6 & 0,9 & 12,9 \\
\hline MT & 0,5 & 0,6 & 90,3 & 8,6 & 100 & 0,9 & 1,5 & 88,5 & 9,1 & 100 & 0,1 & 0,1 & 11,4 & 1,1 & 12,6 & 0,1 & 0,1 & 6,5 & 0,7 & 7,3 \\
\hline MS & 2,0 & 0,3 & 81,5 & 15,9 & 100 & 1,6 & 0,6 & 82,6 & 13,6 & 100 & 0,1 & 0,0 & 5,2 & 1,0 & 6,3 & 0,1 & 0,0 & 4,1 & 0,7 & 5,0 \\
\hline Sudeste & 41,7 & 0,1 & 53,0 & 4,8 & 100 & 42,5 & 0,6 & 49,2 & 7,2 & 100 & 10,5 & 0,0 & 13,3 & 1,2 & 25,1 & 11,3 & 0,2 & 13,1 & 1,9 & 26,6 \\
\hline ES & 16,7 & 0,0 & 35,1 & 48,2 & 100 & 12,5 & 0,0 & 62,5 & 25,0 & 100 & 0,0 & 0,0 & 0,0 & 0,0 & 0,1 & 0,0 & 0,0 & 0,1 & 0,0 & 0,1 \\
\hline $\mathrm{MG}$ & 17,9 & 0,2 & 76,4 & 5,0 & 100 & 15,2 & 0,8 & 72,2 & 10,9 & 100 & 2,1 & 0,0 & 8,9 & 0,6 & 11,7 & 1,4 & 0,1 & 6,8 & 1,0 & 9,4 \\
\hline RJ & 0,0 & 100,0 & 0,0 & 0,0 & 100 & 0,0 & 100,0 & 0,0 & 0,0 & 100 & 0,0 & 0,0 & 0,0 & 0,0 & 0,0 & 0,0 & 0,0 & 0,0 & 0,0 & 0,0 \\
\hline SP & 62,7 & 0,1 & 32,7 & 4,4 & 100 & 57,9 & 0,4 & 36,5 & 5,1 & 100 & 8,4 & 0,0 & 4,4 & 0,6 & 13,4 & 9,8 & 0,1 & 6,2 & 0,9 & 17,0 \\
\hline Sul & 0,9 & 0,4 & 93,6 & 4,6 & 100 & 0,6 & 1,6 & 87,7 & 9,0 & 100 & 0,1 & 0,1 & 14,0 & 0,7 & 15,0 & 0,2 & 0,5 & 24,4 & 2,5 & 27,8 \\
\hline PR & 1,1 & 0,5 & 95,0 & 3,1 & 100 & 0,6 & 1,5 & 94,3 & 3,1 & 100 & 0,0 & 0,0 & 3,7 & 0,1 & 3,9 & 0,0 & 0,1 & 8,1 & 0,3 & 8,6 \\
\hline RS & 0,3 & 0,3 & 93,2 & 5,4 & 100 & 0,4 & 1,7 & 84,8 & 11,8 & 100 & 0,0 & 0,0 & 9,0 & 0,5 & 9,7 & 0,1 & 0,3 & 14,8 & 2,1 & 17,4 \\
\hline $\mathrm{SC}$ & 4,3 & 0,7 & 92,0 & 2,9 & 100 & 3,5 & 1,7 & 84,3 & 9,6 & 100 & 0,1 & 0,0 & 1,3 & 0,0 & 1,4 & 0,1 & 0,0 & 1,5 & 0,2 & 1,8 \\
\hline Brasil & 13,3 & 0,4 & 80,4 & 5,8 & 100 & 13,0 & 1,2 & 77,1 & 8,2 & 100 & 13,3 & 0,4 & 80,4 & 5,8 & 100 & 13,0 & 1,2 & 77,1 & 8,2 & 100 \\
\hline
\end{tabular}

Fonte: resultados da pesquisa. 
Tabela 37. Crédito concedido e observações em iLPF, por regiões e modalidades, em relação ao total das regiões e do Brasil. Em porcentagem (\%).

\begin{tabular}{|c|c|c|c|c|c|c|c|c|c|c|c|c|c|c|c|c|c|c|c|c|c|c|c|c|}
\hline \multirow{2}{*}{ Região } & \multicolumn{6}{|c|}{ CRÉDITO CONCEDIDO } & \multicolumn{6}{|c|}{ OBSERVAÇÕES } & \multicolumn{6}{|c|}{ CRÉDITO CONCEDIDO } & \multicolumn{6}{|c|}{ OBSERVAÇÕES } \\
\hline & $\mathbf{A A}$ & FCP & MEQ & MEX & OM & TOTAL & $\mathbf{A A}$ & FCP & MEQ & MEX & OM & TOTAL & AA & FCP & MEQ & MEX & OM & TOTAL & $\mathbf{A A}$ & FCP & MEQ & MEX & OM & TOTAL \\
\hline Norte & 7,6 & 49,6 & 4,8 & 33,9 & 3,3 & 100 & 8,6 & 21,1 & 7,8 & 53,1 & 7,8 & 100 & 0,4 & 2,7 & 0,3 & 1,8 & 0,2 & 5,4 & 0,5 & 1,1 & 0,4 & 2,8 & 0,4 & 5,3 \\
\hline $\mathrm{AC}$ & 9,6 & 0,0 & 8,8 & 81,6 & 0,0 & 100 & 16,7 & 0,0 & 16,7 & 66,7 & 0,0 & 100 & 0,0 & 0,0 & 0,0 & 0,1 & 0,0 & 0,1 & 0,0 & 0,0 & 0,0 & 0,2 & 0,0 & 0,2 \\
\hline $\mathrm{AP}$ & 0,0 & 0,0 & 0,0 & 0,0 & 0,0 & 0 & 0,0 & 0,0 & 0,0 & 0,0 & 0,0 & 0 & 0,0 & 0,0 & 0,0 & 0,0 & 0,0 & 0,0 & 0,0 & 0,0 & 0,0 & 0,0 & 0,0 & 0,0 \\
\hline $\mathrm{PA}$ & 3,9 & 56,3 & 5,0 & 30,1 & 2,7 & 100 & 13,8 & 13,8 & 17,2 & 41,4 & 10,3 & 100 & 0,1 & 1,2 & 0,1 & 0,6 & 0,1 & 2,1 & 0,2 & 0,2 & 0,2 & 0,5 & 0,1 & 1,2 \\
\hline RO & 12,5 & 0,0 & 44,2 & 43,3 & 0,0 & 100 & 25,0 & 0,0 & 50,0 & 25,0 & 0,0 & 100 & 0,0 & 0,0 & 0,1 & 0,1 & 0,0 & 0,2 & 0,0 & 0,0 & 0,1 & 0,0 & 0,0 & 0,2 \\
\hline $\mathrm{RR}$ & 19,1 & 27,9 & 5,9 & 43,6 & 3,6 & 100 & 16,7 & 16,7 & 11,1 & 50,0 & 5,6 & 100 & 0,1 & 0,2 & 0,0 & 0,3 & 0,0 & 0,8 & 0,1 & 0,1 & 0,1 & 0,4 & 0,0 & 0,7 \\
\hline TO & 6,5 & 59,3 & 0,0 & 29,8 & 4,2 & 100 & 2,8 & 28,2 & 0,0 & 59,2 & 8,5 & 100 & 0,1 & 1,3 & 0,0 & 0,6 & 0,1 & 2,1 & 0,1 & 0,8 & 0,0 & 1,7 & 0,2 & 2,9 \\
\hline Nordeste & 4,0 & 63,3 & 0,1 & 23,0 & 9,3 & 100 & 4,8 & 36,5 & 1,6 & 48,4 & 7,9 & 100 & 0,2 & 3,6 & 0,0 & 1,3 & 0,5 & 5,6 & 0,2 & 1,9 & 0,1 & 2,5 & 0,4 & 5,2 \\
\hline BA & 1,9 & 70,0 & 0,0 & 23,5 & 4,2 & 100 & 2,0 & 41,0 & 0,0 & 49,0 & 7,0 & 100 & 0,1 & 3,4 & 0,0 & 1,1 & 0,2 & 4,8 & 0,1 & 1,7 & 0,0 & 2,0 & 0,3 & 4,2 \\
\hline MA & 20,6 & 21,2 & 0,9 & 16,5 & 40,8 & 100 & 18,8 & 18,8 & 12,5 & 37,5 & 12,5 & 100 & 0,1 & 0,1 & 0,0 & 0,1 & 0,2 & 0,6 & 0,1 & 0,1 & 0,1 & 0,2 & 0,1 & 0,7 \\
\hline $\mathrm{PE}$ & 6,7 & 51,1 & 0,0 & 42,1 & 0,0 & 100 & 14,3 & 28,6 & 0,0 & 57,1 & 0,0 & 100 & 0,0 & 0,1 & 0,0 & 0,1 & 0,0 & 0,1 & 0,0 & 0,1 & 0,0 & 0,2 & 0,0 & 0,3 \\
\hline PI & 0,0 & 0,0 & 0,0 & 0,0 & 100,0 & 100 & 0,0 & 0,0 & 0,0 & 0,0 & 100,0 & 100 & 0,0 & 0,0 & 0,0 & 0,0 & 0,1 & 0,1 & 0,0 & 0,0 & 0,0 & 0,0 & 0,0 & 0,0 \\
\hline Centro-Oeste & 4,3 & 42,9 & 0,7 & 42,8 & 9,0 & 100 & 5,8 & 31,7 & 3,3 & 49,9 & 8,8 & 100 & 1,3 & 12,9 & 0,2 & 12,9 & 2,7 & 30,1 & 1,0 & 5,2 & 0,5 & 8,2 & 1,5 & 16,5 \\
\hline GO & 3,7 & 32,7 & 0,3 & 51,5 & 11,7 & 100 & 4,4 & 35,0 & 2,7 & 48,2 & 9,3 & 100 & 0,5 & 4,3 & 0,0 & 6,8 & 1,5 & 13,2 & 0,4 & 3,3 & 0,2 & 4,5 & 0,9 & 9,4 \\
\hline MT & 7,6 & 31,7 & 1,0 & 55,2 & 4,5 & 100 & 10,8 & 16,9 & 2,4 & 62,7 & 7,2 & 100 & 0,6 & 2,6 & 0,1 & 4,6 & 0,4 & 8,3 & 0,4 & 0,6 & 0,1 & 2,2 & 0,2 & 3,4 \\
\hline MS & 2,0 & 69,0 & 1,0 & 18,1 & 9,1 & 100 & 4,6 & 37,9 & 5,7 & 42,5 & 8,0 & 100 & 0,2 & 6,0 & 0,1 & 1,6 & 0,8 & 8,7 & 0,2 & 1,4 & 0,2 & 1,5 & 0,3 & 3,6 \\
\hline Sudeste & 1,2 & 81,0 & 0,3 & 12,7 & 4,1 & 100 & 0,8 & 53,8 & 1,2 & 38,6 & 5,4 & 100 & 0,6 & 38,8 & 0,1 & 6,1 & 2,0 & 47,8 & 0,5 & 30,5 & 0,7 & 21,8 & 3,0 & 56,6 \\
\hline ES & 0,0 & 79,4 & 0,0 & 9,9 & 5,5 & 100 & 0,0 & 44,6 & 0,0 & 50,5 & 4,3 & 100 & 0,0 & 3,5 & 0,0 & 0,4 & 0,2 & 4,4 & 0,0 & 3,4 & 0,0 & 3,9 & 0,3 & 7,6 \\
\hline MG & 1,5 & 76,6 & 0,3 & 16,2 & 5,1 & 100 & 1,1 & 49,8 & 1,5 & 41,9 & 5,3 & 100 & 0,4 & 20,1 & 0,1 & 4,3 & 1,3 & 26,3 & 0,3 & 13,6 & 0,4 & 11,5 & 1,5 & 27,3 \\
\hline RJ & 0,0 & 47,7 & 0,0 & 52,3 & 0,0 & 100 & 0,0 & 40,0 & 0,0 & 60,0 & 0,0 & 100 & 0,0 & 0,1 & 0,0 & 0,1 & 0,0 & 0,2 & 0,0 & 0,1 & 0,0 & 0,1 & 0,0 & 0,2 \\
\hline SP & 1,0 & 88,7 & 0,2 & 7,7 & 2,4 & 100 & 0,8 & 62,3 & 1,2 & 29,8 & 5,8 & 100 & 0,2 & 15,1 & 0,0 & 1,3 & 0,4 & 17,0 & 0,2 & 13,4 & 0,2 & 6,4 & 1,2 & 21,5 \\
\hline Sul & 14,8 & 24,9 & 0,9 & 46,3 & 12,5 & 100 & 10,7 & 23,1 & 3,0 & 48,5 & 13,5 & 100 & 1,6 & 2,8 & 0,1 & 5,1 & 1,4 & 11,1 & 1,7 & 3,8 & 0,5 & 7,9 & 2,2 & 16,4 \\
\hline PR & 21,9 & 18,1 & 1,8 & 52,0 & 6,2 & 100 & 11,9 & 21,6 & 3,7 & 53,0 & 9,0 & 100 & 0,8 & 0,7 & 0,1 & 1,9 & 0,2 & 3,7 & 0,7 & 1,2 & 0,2 & 2,9 & 0,5 & 5,6 \\
\hline RS & 13,2 & 24,6 & 0,5 & 45,3 & 15,8 & 100 & 12,4 & 18,2 & 3,3 & 48,3 & 16,3 & 100 & 0,8 & 1,5 & 0,0 & 2,8 & 1,0 & 6,2 & 1,1 & 1,6 & 0,3 & 4,2 & 1,4 & 8,7 \\
\hline $\mathrm{SC}$ & 0,0 & 48,6 & 0,0 & 33,1 & 15,2 & 100 & 0,0 & 47,1 & 0,0 & 37,3 & 13,7 & 100 & 0,0 & 0,5 & 0,0 & 0,4 & 0,2 & 1,1 & 0,0 & 1,0 & 0,0 & 0,8 & 0,3 & 2,1 \\
\hline Brasil & 4,1 & 60,6 & 0,7 & 27,2 & 6,8 & 100 & 3,9 & 42,5 & 2,2 & 43,3 & 7,5 & 100 & 4,1 & 60,6 & 0,7 & 27,2 & 6,8 & 100 & 3,9 & 42,5 & 2,2 & 43,3 & 7,5 & 100 \\
\hline
\end{tabular}

Fonte: resultados da pesquisa. 
Tabela 38. Crédito concedido e observações em FLP, por regiões e modalidades, em relação ao total das regiões e do Brasil. Em porcentagem (\%).

\begin{tabular}{|c|c|c|c|c|c|c|c|c|c|c|c|c|c|c|c|c|}
\hline \multirow{2}{*}{ Região } & \multicolumn{4}{|c|}{ CRÉDITO CONCEDIDO } & \multicolumn{4}{|c|}{ OBSERVAÇÕES } & \multicolumn{4}{|c|}{ CRÉDITO CONCEDIDO } & \multicolumn{4}{|c|}{ OBSERVAÇÕES } \\
\hline & FCP & MEX & OM & TOTAL & FCP & MEX & OM & TOTAL & FCP & MEX & OM & TOTAL & FCP & MEX & OM & TOTAL \\
\hline Norte & 93,3 & 0,5 & 6,2 & 100 & 82,5 & 6,3 & 11,3 & 100 & 3,9 & 0,0 & 0,3 & 4,2 & 2,4 & 0,2 & 0,3 & 2,9 \\
\hline $\mathrm{AC}$ & 0,0 & 0,0 & 0,0 & 0 & 0,0 & 0,0 & 0,0 & 0 & 0,0 & 0,0 & 0,0 & 0,0 & 0,0 & 0,0 & 0,0 & 0,0 \\
\hline $\mathrm{AP}$ & 0,0 & 0,0 & 0,0 & 0 & 0,0 & 0,0 & 0,0 & 0 & 0,0 & 0,0 & 0,0 & 0,0 & 0,0 & 0,0 & 0,0 & 0,0 \\
\hline PA & 86,8 & 0,1 & 13,1 & 100 & 66,7 & 16,7 & 16,7 & 100 & 0,2 & 0,0 & 0,0 & 0,2 & 0,1 & 0,0 & 0,0 & 0,2 \\
\hline RO & 86,0 & 1,3 & 12,7 & 100 & 57,1 & 14,3 & 28,6 & 100 & 0,5 & 0,0 & 0,1 & 0,6 & 0,1 & 0,0 & 0,1 & 0,3 \\
\hline RR & 0,0 & 0,0 & 0,0 & 0 & 0,0 & 0,0 & 0,0 & 0 & 0,0 & 0,0 & 0,0 & 0,0 & 0,0 & 0,0 & 0,0 & 0,0 \\
\hline TO & 95,1 & 0,3 & 4,6 & 100 & 86,6 & 4,5 & 9,0 & 100 & 3,2 & 0,0 & 0,2 & 3,4 & 2,1 & 0,1 & 0,2 & 2,5 \\
\hline Nordeste & 88,2 & 0,9 & 10,9 & 100 & 73,6 & 15,5 & 10,9 & 100 & 3,7 & 0,0 & 0,5 & 4,2 & 3,0 & 0,6 & 0,4 & 4,0 \\
\hline BA & 87,4 & 1,0 & 11,7 & 100 & 73,6 & 15,4 & 11,0 & 100 & 3,2 & 0,0 & 0,4 & 3,6 & 2,5 & 0,5 & 0,4 & 3,3 \\
\hline MA & 92,6 & 0,6 & 6,9 & 100 & 80,0 & 13,3 & 6,7 & 100 & 0,4 & 0,0 & 0,0 & 0,5 & 0,4 & 0,1 & 0,0 & 0,6 \\
\hline $\mathrm{PE}$ & 0,0 & 2,0 & 98,0 & 100 & 0,0 & 50,0 & 50,0 & 100 & 0,0 & 0,0 & 0,0 & 0,0 & 0,0 & 0,0 & 0,0 & 0,1 \\
\hline PI & 100,0 & 0,0 & 0,0 & 100 & 100,0 & 0,0 & 0,0 & 100 & 0,1 & 0,0 & 0,0 & 0,1 & 0,1 & 0,0 & 0,0 & 0,1 \\
\hline Centro-Oeste & 92,2 & 0,1 & 7,7 & 100 & 82,0 & 1,3 & 16,7 & 100 & 27,8 & 0,0 & 2,3 & 30,1 & 9,2 & 0,1 & 1,9 & 11,2 \\
\hline $\mathrm{GO}$ & 82,2 & 0,1 & 17,7 & 100 & 80,2 & 1,5 & 18,3 & 100 & 5,2 & 0,0 & 1,1 & 6,4 & 3,9 & 0,1 & 0,9 & 4,8 \\
\hline MT & 90,0 & 0,0 & 10,0 & 100 & 80,0 & 0,0 & 20,0 & 100 & 2,9 & 0,0 & 0,3 & 3,2 & 1,6 & 0,0 & 0,4 & 2,0 \\
\hline MS & 95,6 & 0,1 & 4,3 & 100 & 84,9 & 1,7 & 13,4 & 100 & 19,6 & 0,0 & 0,9 & 20,5 & 3,7 & 0,1 & 0,6 & 4,4 \\
\hline Sudeste & 95,8 & 1,1 & 3,0 & 100 & 91,3 & 2,6 & 5,9 & 100 & 48,3 & 0,6 & 1,5 & 50,4 & 59,0 & 1,7 & 3,8 & 64,7 \\
\hline ES & 90,5 & 1,2 & 8,3 & 100 & 85,7 & 8,9 & 5,4 & 100 & 0,9 & 0,0 & 0,1 & 1,0 & 1,8 & 0,2 & 0,1 & 2,1 \\
\hline MG & 95,2 & 1,7 & 3,1 & 100 & 89,1 & 2,9 & 7,7 & 100 & 25,7 & 0,4 & 0,8 & 27,0 & 23,8 & 0,8 & 2,1 & 26,7 \\
\hline RJ & 62,7 & 6,9 & 24,0 & 100 & 61,5 & 15,4 & 15,4 & 100 & 0,2 & 0,0 & 0,1 & 0,4 & 0,3 & 0,1 & 0,1 & 0,5 \\
\hline SP & 97,4 & 0,3 & 2,3 & 100 & 93,7 & 1,8 & 4,5 & 100 & 21,5 & 0,1 & 0,5 & 22,0 & 33,2 & 0,6 & 1,6 & 35,4 \\
\hline Sul & 87,1 & 10,6 & 2,3 & 100 & 89,1 & 6,2 & 4,7 & 100 & 9,7 & 1,2 & 0,3 & 11,1 & 15,3 & 1,1 & 0,8 & 17,1 \\
\hline PR & 85,8 & 12,3 & 1,9 & 100 & 91,5 & 4,4 & 4,1 & 100 & 7,1 & 1,0 & 0,2 & 8,2 & 9,9 & 0,5 & 0,4 & 10,8 \\
\hline $\mathrm{RS}$ & 88,1 & 7,0 & 4,9 & 100 & 78,8 & 12,5 & 8,8 & 100 & 1,4 & 0,1 & 0,1 & 1,6 & 2,3 & 0,4 & 0,3 & 2,9 \\
\hline $\mathrm{SC}$ & 94,9 & 3,9 & 1,2 & 100 & 90,3 & 6,5 & 3,2 & 100 & 1,2 & 0,0 & 0,0 & 1,3 & 3,1 & 0,2 & 0,1 & 3,4 \\
\hline Brasil & 93,3 & 1,8 & 4,8 & 100 & 88,9 & 3,7 & 7,3 & 100 & 93,3 & 1,8 & 4,8 & 100 & 88,9 & 3,7 & 7,3 & 100 \\
\hline
\end{tabular}

Fonte: resultados da pesquisa. 